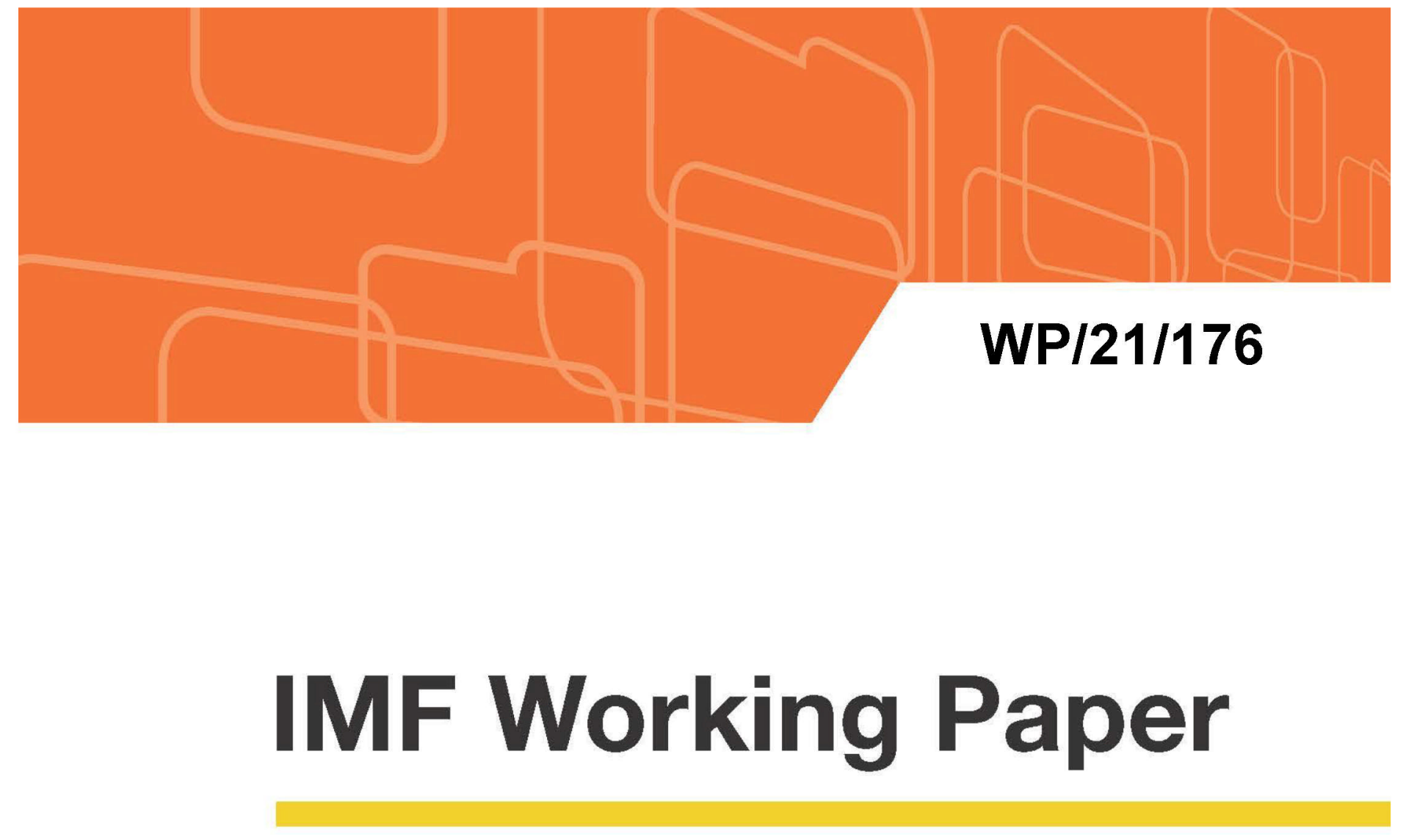

\title{
The Sectoral Trade Losses from Financial Crises
}

by Jean-Marc B. Atsebi, Jean-Louis Combes, Alexandru Minea

IMF Working Papers describe research in progress by the author(s) and are published to elicit comments and to encourage debate. The views expressed in IMF Working Papers are those of the author(s) and do not necessarily represent the views of the IMF, its Executive Board, or IMF management. 


\title{
IMF Working Paper
}

European Department

\author{
The Sectoral Trade Losses from Financial Crises \\ Prepared by Jean-Marc B. Atsebi, Jean-Louis Combes, Alexandru Minea* \\ Authorized for distribution by Ivanna Vladkova Hollar
}

June 2021

\begin{abstract}
IMF Working Papers describe research in progress by the author(s) and are published to elicit comments and to encourage debate. The views expressed in IMF Working Papers are those of the author(s) and do not necessarily represent the views of the IMF, its Executive Board, or IMF management.
\end{abstract}

\begin{abstract}
The "Great Trade Collapse" triggered by the 2008-09 crisis calls for a careful assessment of the trade losses from financial crises. We adopt a more detailed perspective by looking at the response of different types of trade (i.e. agricultural, mining, and manufactured goods, and services) following various types of financial crises (i.e. debt, banking, and currency crises). Estimations performed on the 1980-2018 period using a combination of impact assessment and local projections to capture a causal dynamic effect running from financial crises to the trade activity show that the collapse of total trade is long-lasting and mainly driven by the fall of manufacturing and to some extent services trade. These causal effects are found to operate through three channels: a structural, a demand-side, and a supply-side channel. By contributing to the understanding of the trade effects of financial crises, our analysis provides insightful support for the design and implementation of policies aimed at coping with these effects.
\end{abstract}

JEL Classification Numbers: F14; F41; G01

Keywords: Trade Losses; Financial Crises; Impact Assessment; Local Projections.

Author's E-Mail Address: JAtsebi@,imf.org, J-louis.Combes@uca.fr, Alexandru.Minea@uca.fr

\footnotetext{
* Jean-Marc B. Atsebi is economist a t the IMF's European Department. Jean-Louis Combes is full professor of economics at University Clermont Auvergne-CERDI. Alexandru Minea is full professor of economics at University Clermont Auvergne. The a uthors thank Cheikh Gueye, Ivanna Vla dkova Hollar, Bas Bakker, Jorge Sa las, Marcos Poplawski Ribeiro as well as seminar participants at University Clermont Auvergne - CERDI, 68th Congress of the French Economic Association (AFSE), 36th International Symposium on Money, Banking and Finance, Besançon for useful comments and suggestions. All rema ining errors and omissions are our own.
} 


\section{Contents}

Abstract.

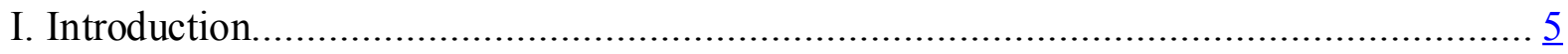

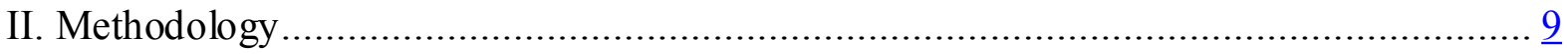

A. Local projection model.............................................................................. 10

B. The augmented inverse propensity weighted (AIPW) estimator............................... 11

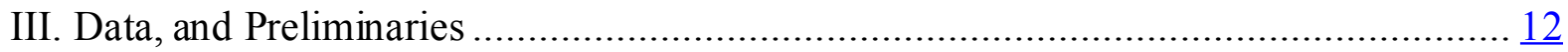

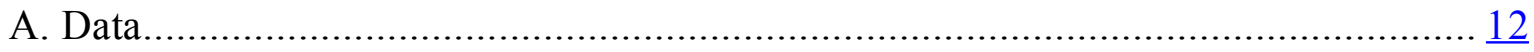

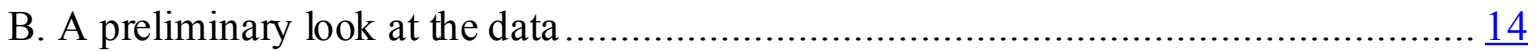

B.1. The occurrence of financial crises........................................................... 15

B.2. The connections between financial crises .................................................. 15

B.3. Financial crises and international trade.................................................... 17

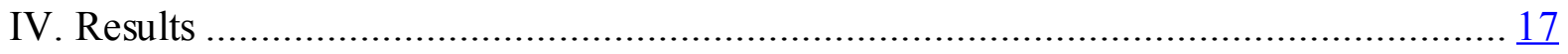

A. Estimation of propensity scores.................................................................. 17

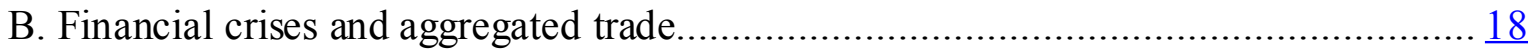

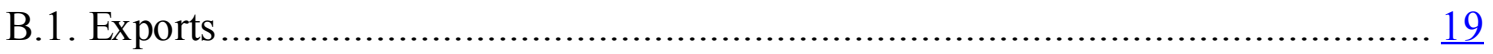

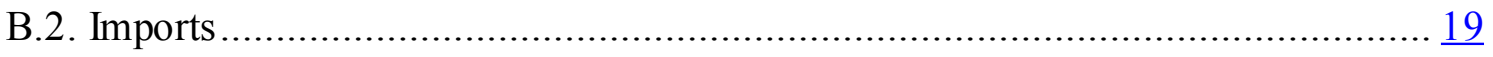

B.3. Trade balance

C. The sectoral trade losses from financial crises................................................. 21

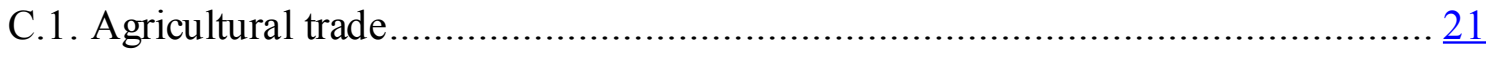

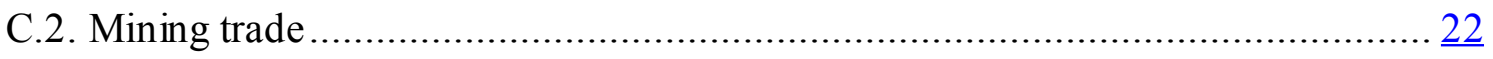

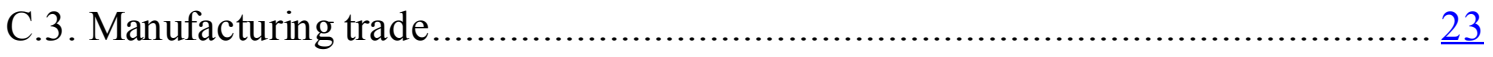

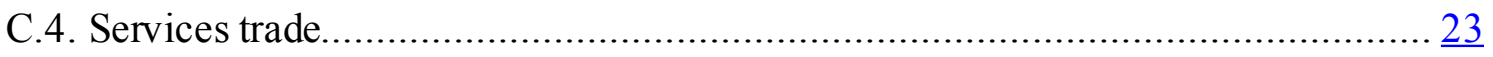

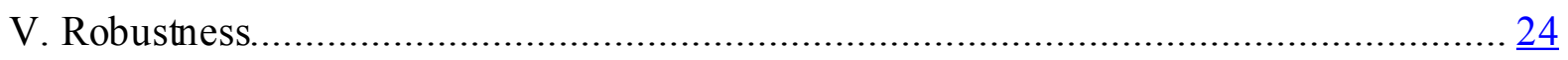

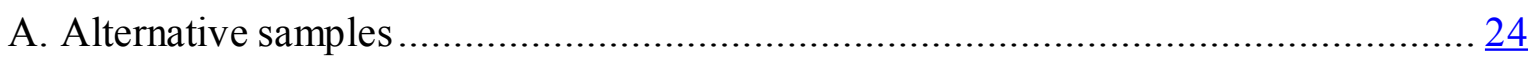

A.1. The trade losses from combined financial crises............................................. 24

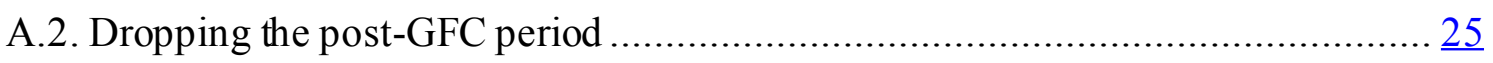

B. Alternative maximum weights set in the treatment models ……………………..... 25

C. Alternative sources and definitions of crises .................................................... 25

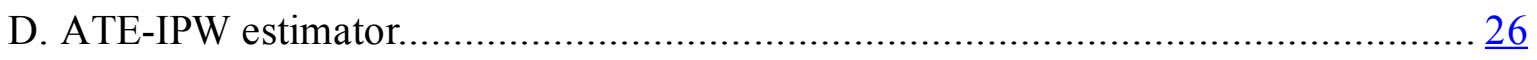

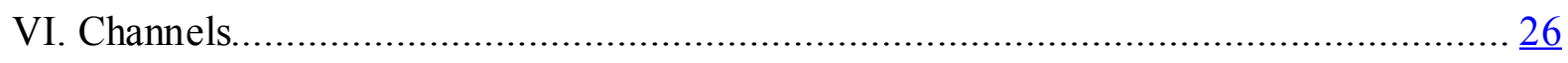

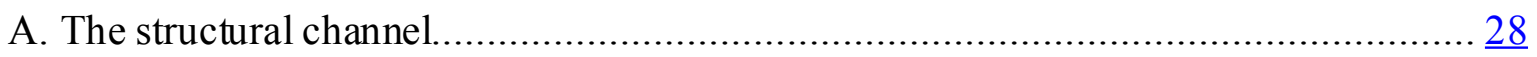

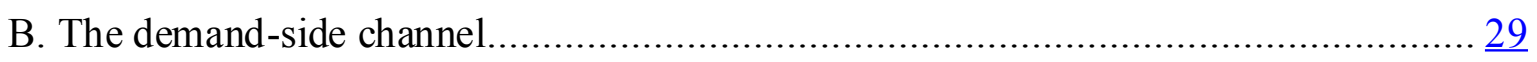

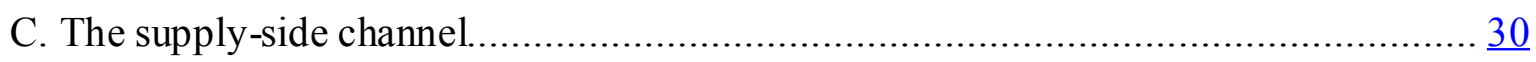




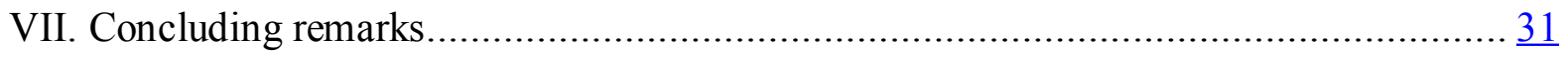

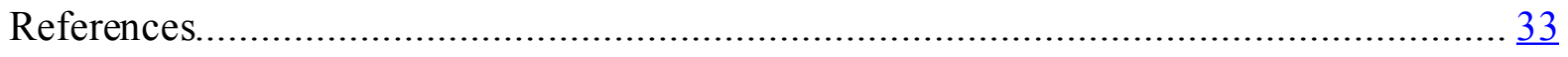

Appendix I. Sample, variables descriptions and sources ............................................... $\underline{39}$

A. Financial crises since 1980 in all emerging countries .............................................. $\underline{39}$

B. List of countries included in regressions analyses.................................................. $\underline{39}$

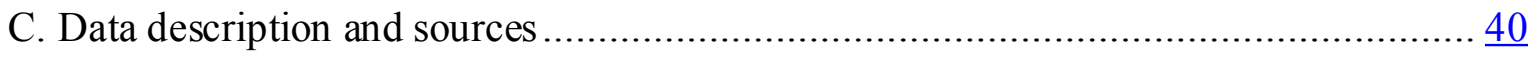

Appendix II. Summary statistics............................................................................ 4

Appendix III. Balance and overlap checks ............................................................. 42

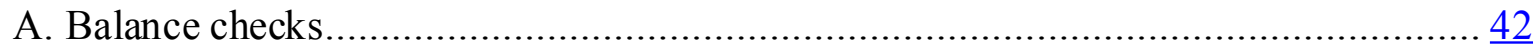

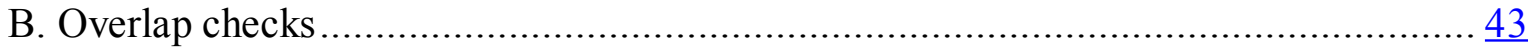

Appendix IV. Supplementary graphs and tables ....................................................... 44

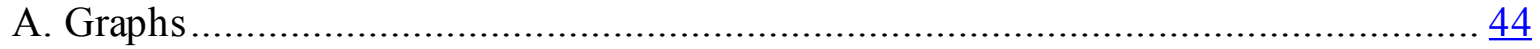

A.1. Benchmark and robustness results ............................................................ 44

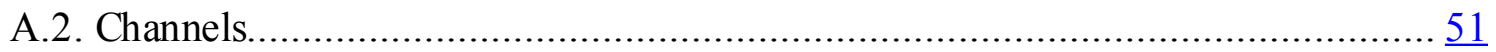

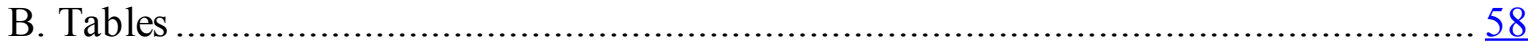

B.1. First stage model, pooled probit.............................................................

B.2. Benchmark and robustness results...........................................................

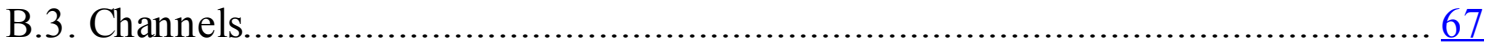




\section{INTRODUCTION}

The recent 2008-09 crisis can be qualified as the "Great Trade Collapse" due to its profound effects on international trade. ${ }^{2}$ Indeed, according to the WTO and IMF, the drop in world trade flows (around 12 percent of world GDP in 2009) exceeded that of world GDP (about 5 percent in 2009). Given the worldwide benefits of trade, ${ }^{3}$ this severe downturn brought back into the spotlight the issue of the trade losses associated with financial crises.

By adopting a macroeconomic perspective, most existing studies focus on gravity models estimated on data of bilateral trade of goods between countries. In a panel of 150 countries, Rose (2005) finds a negative effect of debt crises on the trade between a debtor (defaulting country) and its creditors (the countries affected by the default), a result extended by Martinez and Sandleris (2011) to all trading partners of a defaulting country (i.e. both creditors and non-creditors) and confirmed more recently by Asonuma et al. (2016) in a treatment effect analysis. Such a detrimental effect on trade is equally emphasized for banking and currency crises, with some exceptions. Indeed, Ma and Cheng (2005) reveal that imports decline following both banking and currency crises, while exports decrease (increase) following banking (currency) crises. Abiad et al. (2014) conclude that debt and banking crises do not significantly affect exports, while they in duce a sharp and long-lasting decline of imports. Altogether, apart from the inconclusive findings for exports, there exists a fairly strong consensus on the detrimental consequences of financial crises on trade at the macroeconomic level. However, this literature may be developed along several dimensions. First, most of the existing papers use trade data only for goods and do not account for trade in services, which may have greater resilience to financial crises according to Borchert and Mattoo (2010) and Ariu (2016). Second, since financial crises are likely not exogenous,

\footnotetext{
${ }^{2}$ Baldwin (2011) reports that global trade fell for at least three quarters only in three of the worldwide recessions that occurred between 1965 and 2008: the oil-shock recession of 1974-75, the inflation-defeating recession of 1982-83, and the Tech-Wreck recession of 2001-02. However, the "Great Tra de Collapse" of $2008-09$ is by far the la rgest trade collapse since the WWII.

${ }^{3}$ Early studies by Dollar(1992); Sachs and Warner(1995); Edwards (1998), and Frankel and Romer(1999) suggest that tra de increases income, a result confirmed more recently by Rodriguez and Rodrik (2000) and Feyrer (2009a,b). Besides, international tra de was a lso found to support overall and firm spoductivity or real consumption, and to reduce poverty (see e.g. Bernard and Jensen, 1999; Pavcnik, 2002; Trefler, 2004; Burstein and Cravino, 2015; Edmond et al., 2015; Johns et al., 2015).
} 
existing studies, with the notable exception of Asonuma et al. (2016), may not capture a causal effect. Third, given the focus on the trade losses from each crisis taken separately without controlling for other crises, the effects may be overestimated since the different crises may be interrelated. Fourth, and more importantly, nothing is said on potential crosssectoral differences in the effects of financial crises: different types of goods and services have different characteristics (e.g. in terms of demand elasticity, reliance on external financing, use as intermediate goods, vertical linkages, and so forth) that make them more or less vulnerable to financial crises.

Motivated by the great trade collapse, several contributions explain the contraction of trade following financial crises through two mechanisms, the income channel and the disruption channel. ${ }^{4}$ Focusing on the demand side, the income channel suggests that financial crises reduce trade through their recessionary effect on income (see Reinhart and Rogoff, 2009), which leads to a fall in consumption, investment, and imports. For example, Freund (2009) finds that the income elasticity of trade increased from under 2 in the 1960 s to over 3.5 in recent years, meaning that nowadays trade could fall about 3.5 times more than GDP. Such a disproportionate fall of the demand, and particularly of durable and investment goods, is indeed at work following the 2008-09 great trade collapse (see e.g. Bricongne et al., 2012; Behrens et al., 2013; Eaton et al., 2016). Conversely, focusing on the supply side, the disruption channel is supported by Iacovone and Zavaka (2009); Amiti and Weinstein (2011); Minetti and Zhu (2011); Chor and Manova (2012); Zymek (2012), and Manova (2013), who insist on the role of credit conditions (for example, financial development weakness) and trade credit (for example, external finance dependency) for explaining the decline of international trade following financial crises, while Bems et al. (2011); Altomonte et al. (2014) and Ariu (2016) point out the role played by the disruption of global value chains. Although these studies focus on the within-manufacturing comparison of industries over the recent period (i.e. following the great trade collapse of 2008-09), they suggest that not all types of goods and services may be equally affected by financial crises, due to

\footnotetext{
${ }^{4}$ See e.g. Berman and Martin (2012) and Ariu (2016) for an extensive discussion of these two channels.
} 
differences in their demand elasticity, external financing needs, vertical linkages through value chains, and their different perception by customers and investors.

Taking stock of the existing literature, the goal of our paper is to assess the trade losses from financial crises by adopting a sectoral perspective. Indeed, except for the aggregate trade of goods and trade in manufactured goods, the literature has so far remained fairly silent regarding the patterns of trade in agricultural or mining goods, or services, following historical financial crises. Moreover, compared with the recent literature that mainly focuses on the 2008-09 crisis, we draw upon a sample of 41 emerging countries over the period 1980-2018 to analyze the trade effects of several types of financial crises, namely $38 \mathrm{debt}$ crises, 34 banking crises, and 36 currency crises. To treat potential endogeneity issues and provide a dynamic view of the trade losses from financial crises, we employ a novel method that combines local projections à la Jordà (2005) and impact assessment with the Augmented Inverse Propensity Weighted estimator.

Our results are as follows. First, consistent with the existing literature, we find that aggregate exports and imports fall by 5.6 and 11 percentage points (pp.) of pre-crisis GDP following debt crises, 8.9 and 14 pp. following banking crises, and 7.7 and $9.1 \mathrm{pp}$. following currency crises, respectively, over five years.

Second, we go beyond existing studies and disaggregate trade losses by type of goods and services. We find that manufacturing goods are most affected by financial crises. However, the impact of financial crises on other types of traded goods and especially on services is far from being negligible. Trade in both mining goods and services (particularly after banking crises) also declines following several types of financial crises, while trade in agricultural goods seems to benefit from a possible substitution effect particularly following debt crises. When looking at the trade losses from combined crises, we find that they exert a significant and higher decline of trade, compared to an individual crisis (i.e. one that it is not accompanied by other crises in the years around it).

Third, robust to a wide variety of alternative specifications, including alternative samples, maximum weights in the treatment models, sources and definitions of crises, and econometric estimators, our findings are explained by three channels: (i) a structural channel, (ii) a demand channel, and a (iii) supply channel. Regarding (i), the structural channel, we 
find that financial crises may act as an impediment of structural transformation, since they hurt relatively more manufacturing exports in countries where the share of manufacturing exports is relatively lower. Moreover, the trade losses from financial crises are significantly lower for countries with diversified export products and trading partners; suggesting that by diversifying their exports and partners, countries can increase their resilience to financial crises. Regarding (ii), the demand channel, we find that financial crises that are associated with lower demand for goods and services from trading partners have more adverse trade impacts, particularly for manufacturing trade: agricultural and mining goods and services may have a lower income elasticity of demand compared with manufactured goods, which makes them more resilient to crises. For instance, the demand for agricultural goods may not contract too much when income decreases, since they are often necessary for subsistence, and they are usually low-priced; relatedly, Borchert and Mattoo (2010) outline that the focus on the trade of goods has obscured the quiet resilience of the trade of services during the recent crisis, which may be explained according to Ariu (2016) by their lower GDP growth elasticity compared with the elasticity of exports of goods (and also by the fact that services are intangible products that cannot be stored and used as collateral for requesting financing, and essential inputs for maintaining a production activity). On the contrary, the income elasticity of demand is high for manufactured goods, and particularly for durable and investment goods: Eaton et al. (2016) show that the decline of demand for "postponable" (durable and non-durable) manufactured goods drives the overall collapse in trade, and plays a role in the contagion to other countries, consistent with the findings of Levchenko et al. (2010) of a strong decline in the trade in durable and intermediate inputs following the 200809 crisis. Finally, regarding (iii), the supply channel, when associated with a deterioration of domestic and external financial conditions and sudden stops, financial crises exert a significant and detrimental effect on international trade that is mainly driven by the fall of manufacturing and services trade. Indeed, the stronger decline in the trade of manufactured goods during periods of credit crunch or deterioration in external financial conditions associated with financial crises may be related to the fact that their production and transport rely relatively more on external finance compared with agricultural and mining goods; as such, by severely limiting external finance, a credit crunch reduces firms' production and export capacities, as discussed by Iacovone and Zavaka (2009); Amiti and Weinstein (2011); 
Minetti and Zhu (2011); and Zymek (2012) in the industry sector. Conversely, the production of agricultural and mining goods and services may require less external financing; for instance, mining goods are produced by large companies (often multinationals) that may rely on self-financing and own cash reserves than firms operating in the manufacturing sector. In addition, since most global value chains concern the production of manufactured goods, the interruption of a link in an international production chain and trade credit, due to a crisis in one country, can lead to the destruction of the entire chain, and further to a larger decline in the trade of manufactured goods. Altogether, these rich and detailed results unveil the complex panorama of the trade losses resulting from financial crises.

The rest of this paper is structured as follows. Section II. details the methodology, Section III. describes the data, Section IV. presents the main results, Section V. analyzes their robustness, Section VI. discusses potential channels, and Section VII. concludes the paper.

\section{METHODOLOGY}

The causal effect going from financial crises to international trade is likely to be affected by endogeneity, arising from different characteristics between countries that experience or not financial crises, ${ }^{5}$ or from reverse causality between trade and financial crises. ${ }^{6}$ We tackle these issues using a combined method of impact assessment methodology (IAM) and local projections (LP) à la Jordà (2005), following Asonuma et al. (2016); Forni et al. (2016); Jordà et al. (2016) and Kuvshinov and Zimmermann (2019), which consists of three steps. First, we estimate the likelihood of financial crises (i.e. the propensity score) based on their determinants. Second, we fit an outcome model in which changes in trade flows at each horizon scaled by pre-crisis GDP are explained by some factors. Third, we compute a semiparametric estimator of the average treatment effect (ATE), namely the Augmented Inverse Propensity Weighted (AIPW), using the predicted propensity scores obtained from the first

\footnotetext{
${ }^{5}$ Tables C.3 to C.5 in A. reveal that countries that experience financial crises present different fundamentals compared with countries that do not.

${ }^{6}$ The litera ture has by now emphasized that trade may lead to financial crises and play an important role in their contagion; see e.g. Krugman (1979); Eichengreen and Rose(1999); Glick and Rose(1999); Forbes (2001) and Ma and Cheng (2005).
} 
stage, and the observed and the potential (predicted in the second stage) values of the change in trade flows. In the following, we describe the LP model and the AIPW estimator.

\section{A. Local projection model}

LP was extensively used to estimate fiscal multipliers, the effects of fiscal consolidations, and the consequences of financial crises, see e.g. Auerbach and Gorodnichenko (2012a,b); Owyang et al. (2013); Asonuma et al. (2016); Forni et al. (2016); Jordà et al. (2016);

Kuvshinov and Zimmermann (2019), and its popularity is supported by several aspects. First, being a flexible, semi-parametric method to estimate dynamic effects, it captures both the direct and indirect (i.e. through changes in fundamentals) effect of financial crises on trade. Second, LP easily accounts for a nonlinear response of trade, which may be potentially at work in our analysis. Third, it can be estimated through standard regression models, and easily combined with IAM. Based on the standard setup in the literature, we estimate the following LP model

$\Delta y_{i, t+h}^{k}=\Lambda^{k, d, h} D_{i, t}^{d}+\Lambda^{k, b, h} D_{i, t}^{b}+\Lambda^{k, c, h} D_{i, t}^{c}+\theta_{L 1}^{k, h} \Delta y_{i, t-1}^{k}+\theta_{L 2}^{k, h} \Delta y_{i, t-2}^{k}+X_{i, t+h}^{x} \beta^{k, h}+v_{i, t+h}^{k}$

for the time-horizon $h \in \llbracket 0 ; 5 \rrbracket$, where $\Delta y_{i, t+h}^{k}=\left(y_{i, t+h}^{k}-y_{i, t-1}^{k}\right) / G D P_{t-1} \times 100$ is the cumulative change between $t-1$ and $t+h$ in 100 times the trade flows of variable $k$ of country $i$ scaled by pre-crisis GDP. $k$ denotes exports/imports of agricultural, mining, and manufactured goods, and services. $D_{i, t}^{d}, D_{i, t}^{b}$, and $D_{i, t}^{c}$ are dummies for debt, banking, and currency crises, respectively, equal to 1 at the start of each financial crisis, and to 0 in noncrises years. As such, we focus on the initiation of the crises, and drop all non-starting years of crises to ensure that the counterfactuals include only periods without any crisis. Their effects at each horizon $h$ are captured through $\Lambda^{k, d, h}, \Lambda^{k, b, h}$, and $\Lambda^{k, c, h}$, respectively, $\Delta y_{i, t-1}^{k}$ and $\Delta y_{i, t-2}^{k}$ are respectively the change in the trade flows (of trade variable $k$ ) one and two years prior to the financial crisis. Finally, $X_{i, t+h}^{x}$ is a set of control variables, and $v_{i, t+h}^{k}$ is the error term. ${ }^{7}$

\footnotetext{
${ }^{7}$ We include all the dummies of the financial crises at the sa me time to a ccount for their correla tion and avoid an overestimated bias of financial crises. We do not include country-fixed effects as the variables a re included as differences.
} 


\section{B. The augmented inverse propensity weighted (AIPW) estimator}

Our impact assessment considers that financial crises are the treatment variable, and changes in trade flows at each horizon $h$ are the outcome variable. Simplifying the algebra by dropping the indexes $k$ for the different dependent variables, and $d, b$, and $c$ for financial crises, the average treatment effect (ATE) is defined as

$$
A T E=\Lambda^{h}=\mathbb{E}\left[y_{i, t+h}(1)-y_{i, t-1} \mid D_{i, t}=1\right]-\mathbb{E}\left[y_{i, t+h}(1)-y_{i, t-1} \mid D_{i, t}=0\right] ; \forall h
$$

Since $\mathbb{E}\left[y_{i, t+h}(1)-y_{i, t-1} \mid D_{i, t}=0\right]$ is not observable, we use a counterfactual. Under the independence assumption $\left[y_{i, t+h}^{\phi}(d)-y_{i, t-1}\right] \perp D_{i, t} \mid Z_{i, t} ; \forall h ; d \in\{0 ; 1\}$, i.e. an independent financial crises allocation of potential outcomes conditional on a set of covariates $Z_{i, t}$, we estimate the ATE by comparing trade in countries with and without financial crises conditional on the set of variables $Z_{i, t}$.

$$
A T E=\Lambda^{h}=\mathbb{E}\left[y_{i, t+h}(1)-y_{i, t-1} \mid D_{i, t}=1 ; Z_{i, t}\right]-\mathbb{E}\left[y_{i, t+h}(0)-y_{i, t-1} \mid D_{i, t}=0 ; Z_{i, t}\right] ; \forall h
$$

In this study, we use the AIPW estimator that requires estimating two models, namely the treatment and the outcome model. Regarding the former, we estimate a covariate balancing propensity score (CBPS) model for each crisis on variables $Z_{i, t}$, and obtain the propensity score for country $i$ at time $t$ to be in the treated, $\hat{p}_{i, t}=p_{1}\left(Z_{i, t} ; \widehat{\Psi}\right)$, and control, $\widehat{1-p}_{i, t}=$ $p_{0}\left(Z_{i, t} ; \widehat{\Psi}\right)$, group. Introduced by Imai and Ratkovic (2014), the CBPS model presents several advantages over the traditional logit or probit models: it ensures the perfect balancing of covariates between the treated and control groups, and it limits the bias due to misspecification in the treatment model (see, tables C.3 to C.5). Introduced by Rosenbaum and Rubin (1983), the propensity score is particularly appealing for our analysis to eliminate the biases between the treated and the control group; we use weighting by propensity scores to mimic a situation where financial crises happen randomly. ${ }^{8}$ Regarding the latter, the outcome model eq. (1) is estimated separately on both treated and control groups, and we predict the potential outcome $\widehat{\mathbb{E}}\left[y_{i, t+h}-y_{i, t-1} \mid D_{i, t}=\mathrm{d} ; X_{i, t}\right] ; \forall \mathrm{d} \in\{0 ; 1\}$ for the entire

\footnotetext{
${ }^{8}$ Following Imbens (2004) and Cole and Hernán (2008), we truncated the maximum weight, defined by $\hat{p}_{i, t}{ }^{-1}$ for the trea ted group and $\left(1-\hat{p}_{i, t}\right)^{-1}$ for the control group, to 10 . In the robustness analysis we change the maximum weight to 5 and 20 .
} 
sample, based on the characteristics of each group. This provides the potential trade for countries in the treated (control) group if they have not (have) experienced crises, conditional on the set of control variables $X_{i, t} \cdot{ }^{9}$ Following the general expression of the AIPW provided by Lunceford and Davidian (2004), we compute the estimated ATE of financial crises on international trade for h year-horizon as

$$
\begin{aligned}
\widehat{\Lambda}_{A l P W}^{h}=\frac{1}{n} \sum_{i} \sum_{t} & \left(\left[\frac{D_{i, t}\left(y_{i, t+h}-y_{i, t-1}\right)}{\hat{p}_{i, t}}-\frac{\left(1-D_{i, t}\right)\left(y_{i, t+h}-y_{i, t-1}\right)}{1-\hat{p}_{i, t}}\right]\right. \\
& -\frac{D_{i, t}-\hat{p}_{i, t}}{\hat{p}_{i, t}\left(1-\hat{p}_{i, t}\right)} \\
& \left.\times\left[\left(1-\hat{p}_{i, t}\right) \widehat{\mathbb{E}}\left[y_{i, t+h}-y_{i, t-1} \mid D_{i, t}=1 ; X_{i, t}\right]+\widehat{p}_{i, t} \widehat{\mathbb{E}}\left[y_{i, t+h}-y_{i, t-1} \mid D_{i, t}=0 ; X_{i, t}\right]\right]\right)
\end{aligned}
$$

This semi-parametric estimator has the distinctive property of being the most efficient doubly robust estimator, namely, it is unbiased when at least the outcome or the treatment model is correctly specified (see e.g. Leon et al., 2003; Imbens, 2004; Lunceford and Davidian, 2004; Tsiatis and Davidian, 2007; Wooldridge, 2007; Kreif et al., 2013). Besides, compared with the inverse propensity weighted (IPW) estimator, it includes an additional adjustment term consisting of the weighted average of the two predicted potential outcomes, which stabilizes the estimator when the propensity scores get close to zero or one, and has expectation zero when either the treatment or the outcome model is correctly specified (see Glynn and Quinn, 2009). Finally, Glynn and Quinn (2009) conclude that the AIPW estimator displays comparable or lower mean square error than competing estimators when the treatment and outcome models are both properly specified and outperforms them when one of these models is misspecified.

\section{Data, AND PRELIMINARIES}

\section{A. Data}

Our unbalanced panel covers 38 debt crises, 34 banking crises, and 36 currency crises in 41 emerging countries that experienced at least one of these crises during the period 1980-2018.

\footnotetext{
${ }^{9}$ Following Asonuma et al. (2016); Jordà et al. (2016), and Kuvshinov and Zimmermann (2019), we use a larger set of controls in the treatment model compared with the outcomemodel; indeed, Lunceford and Davidian (2004) suggests including as many variables as collected in the treatment model.
} 
We focus on emerging countries for several reasons. First, trade has increased more in these countries over the past decades, and represents today a large share of world trade. ${ }^{10}$ Second, the way international trade reacts to financial crises depends on the development level and the trade structure; therefore, focusing on emerging countries increases the homogeneity of the effects of financial crises. Third, emerging countries have been much more affected by all types of crises than low-income and developed countries. ${ }^{11}$

Regarding financial crises, data for debt crises come from Reinhart and Rogoff (2009), data for banking crises are from Laeven and Valencia (2018), and data for currency crises are built using the definition of Frankel and Rose (1996). Debt crises are defined as the failure of the government to meet a principal or interest payment on the due date and/or the episodes of post-default debt restructuring. Banking crises are defined as events where there are signs of financial distress in the banking system (as indicated by significant bank runs, losses in the banking system, and/or bank liquidations) and/or banking policy intervention measures in response to significant losses in the banking system. Currency crises are defined as a nominal depreciation of the local currency against trading partners' currencies of at least 25 percent that is also at least a 10 percent increase in the rate of depreciation. Alternative definitions and sources for crises are considered in the robustness analysis.

Trade data on goods come from UN Comtrade, via the World Trade Integrated Solution (WITS)-World Bank, which provides exports and imports at the 3 -digit code of the Standard International Trade Classification (SITC). We classify this disaggregated data into three types of goods, namely agricultural, mining, and manufactured goods, following the WTO classification. Compared with most studies that focus exclusively on the export of goods, we also consider the import of goods, which can improve firms' productivity and export competitiveness. In addition, we equally consider the trade of services (data comes from United Nations Conference on Trade and Development-UNCTAD), which represents as

\footnotetext{
${ }^{10}$ On the export side, the emerging economies' share tradehas increased from a round 19 percent of world exports in the early 1990 s to close to 40 percent recently. On the import side, the share has increased

${ }^{11}$ Indeed, a dvanced economies mostly experienced banking crises, and low-income countries mostly experienced debtcrises. Only emerging market countries experienced debt, banking, and currency crises. Given the da ta limita tions, we can therefore a nalyze the trade losses of all three types of crises for emerging countries only.
} 
large as one-quarter of total exports and imports in our sample; besides, since they mostly concern intermediate inputs, ${ }^{12}$ their decrease may have strong (negative) effects on the economy. Total trade is obtained by aggregating the four categories of goods and services (agriculture, mining, manufacturing, and services), and deflated by export/import prices. ${ }^{13}$

Finally, we consider two sets of control variables in line with the existing literature that we extend further. The first set is used in the treatment model and includes those variables that influence the likelihood of financial crises and are correlated with international trade, namely, following the related literature: (i) number of past-5 years financial crises except the one of interest, (ii) intensity of conflicts, (iii) log of Real GDP, (iv) log of public debt to GDP, (v) log of domestic credit to GDP, (vi) log of liquid liabilities to GDP, (vii) net capital inflows to GDP, (viii) log of foreign reserves to GDP, (ix) current account to GDP, (x) financial openness index, (xi) log of trade openness to GDP, (xii) terms of trade growth, (xiii) floating exchange rate regime dummy, (xiv) government accountability index, (xv) corruption index, (xvi) trading partners' growth, and (xvii) US interest rate on government's securities. These predictors of financial crises are included one-year lagged. The second set of control variables is used in the outcome model eq. (1) to predict the changes in trade at each horizon $\mathrm{h}$ for each type of good and for services, namely: (i) the change of trade flows one and two years before the onset of financial crises, (ii) other crises, and (iii) the exchange rate regimes at horizon $h .{ }^{14}$ The sources and summary statistics are provided in Appendix I.C. and Appendix II., respectively.

\section{B. A preliminary look at the data}

In this section, we discuss three features of financial crises: their occurrence, the connections between different types of financial crises, and their link with international trade.

\footnotetext{
${ }^{12}$ According to Borchert and Mattoo (2010), tra de in services a ccounts for over one-fifth of global cross-border tra de, and up to one-third of exports in some large countries (including US or India); a nd Miroudot et al. (2009) conclude that roughly three-fourth of tra de in services in OECD a re intermediate inputs from 20 to 35 percent over the same period.

${ }^{13}$ The pa irwise correla tions between our aggregate trade dataset with existing datasets on aggregate trade (UN Comtrade or IMF Direction of Tra de Statistics) are higher than 0.95 . This ind icates that our data are properly compiled using disa ggregate trade.

${ }^{14}$ In the section devoted to the transmission channels we consider additional va riables.
} 


\section{B.1. The occurrence of financial crises}

The evolution of financial crises during the period 1980-2014 is summarized in Figure 1. According to (A), all types of crises are recurrent in emerging markets and occurred by clusters (e.g., the debt crises in Latin America and Africa in the 1980s, the banking and currency crises in Asia, Latin America, and Eastern Europe of the 1990s). ${ }^{15}$ Moreover, as shown by (B), crises are long-lasting, and emerging markets suffered debt crises (especially in the 1980s and 1990s) more often than banking and currency crises. Finally, (C) suggests that financial crises strike the economies by clusters and spread within the regions: countries in Africa, Latin America, and Middle-East are more affected by debt crises than countries in other regions, countries in Latin America, Europe, and Central Asia, and East Asia and Pacific are more affected by banking crises, and countries in Europe, Central Asia, and Latin America are more affected by currency crises.

Figure 1: Financial crises over time and by regions
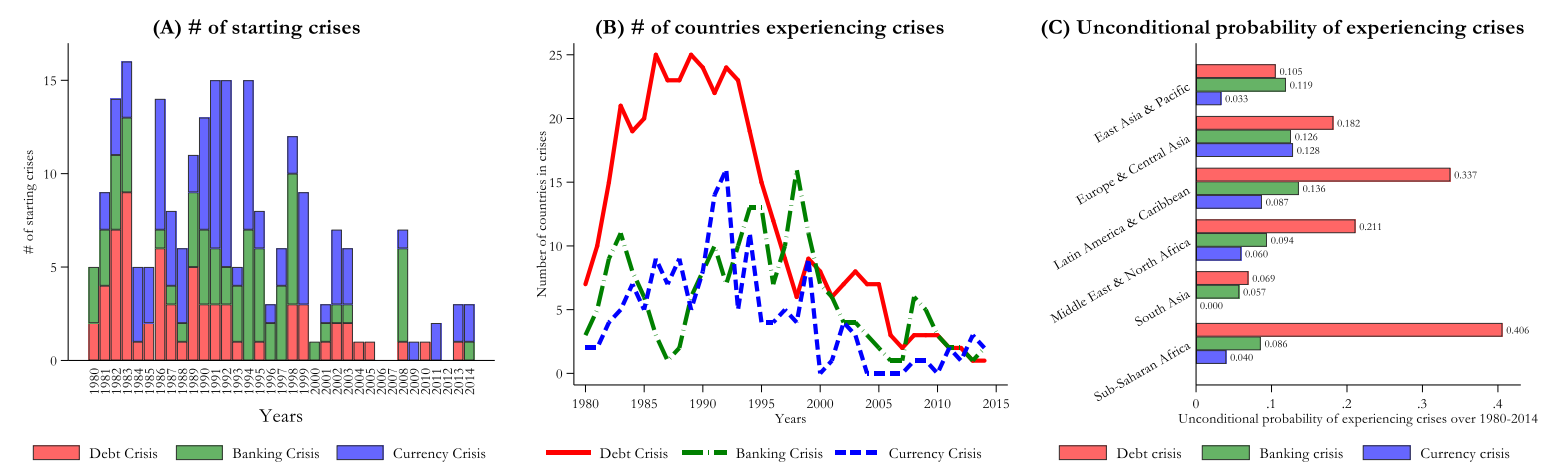

Notes: Sa mple: 1980-2014. Authors' calculations based on data and definitions from Fra nkel and Rose (1996); Reinhart and Rogoff(2009) and Laeven and Valencia (2018), World Development Indicators.

\section{B.2. The connections between financial crises}

We analyze potential connections between financial crises using the standard nonparametric Kaplan-Meier estimator. The main message of fig. 2 is that financial crises of a new type occur significantly quicker after a crisis of another type: (i) after a debt crisis hits a country, a banking crisis follows in one-quarter of cases in five years, and a currency crisis in one year; (ii) after a banking crisis, a debt or currency crisis follows in one-quarter of cases in two

\footnotetext{
${ }^{15}$ The number of crises follows a downward trend since the beginning of the 2000 s (the Great moderation period), and the 2008-09 contraction has been characterized by less incidence of debt, banking, and currency crises in emerging countries compared to a dvanced economies.
} 
years; (iii) after a currency crisis, a debt crisis follows in one-quarter of cases in two years, and a banking crisis in four years. Consequently, the takeaway for the design of our empirical analysis is that when estimating the effect of a crisis one should systematically control for other crises to avoid overestimating its trade losses.

Figure 2: Survival models of the duration between the onset of different financial crises

(A) Probability of avoiding crises following a debt crisis
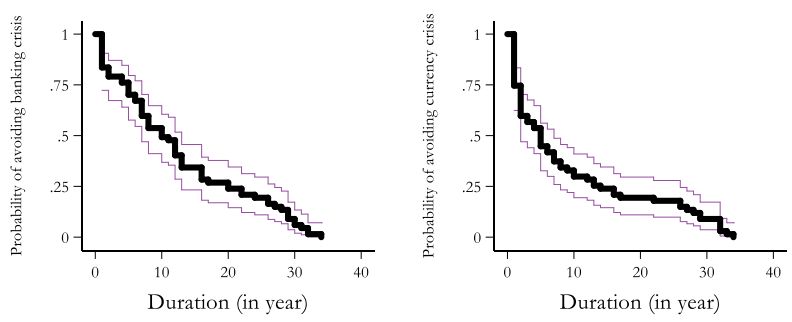

$95 \%$ CI - Survivor function

(B) Probability of avoiding crises following a banking crisis
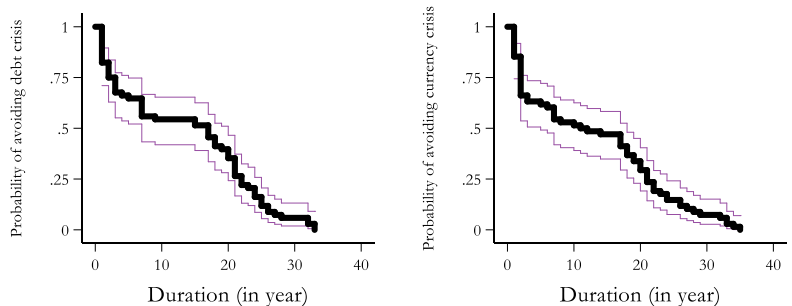

$95 \% \mathrm{CI} \quad$ Survivor function

(C) Probability of avoiding crises following a currency crisis
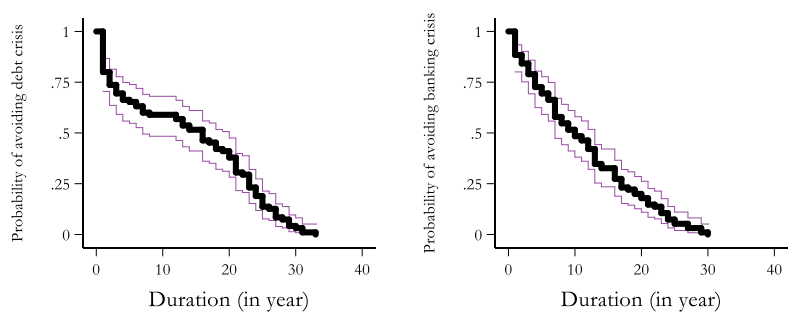

95\% CI - Survivor function

Notes: The figure plots the estimated Ka plan-Meier survival functions for the duration between the start of one type of crisis and the start of a nother type of crisis. The $y$-axis denotes the compound probability that countries a void crises. From the top row to the bottom row, we describe the probability of avoiding crises on the $y$-axis following debt, banking, and currency crises, respectively. The bands a re 95 percent confidence intervals. Authors' ca lculations based on data and definitions from Frankel and Rose(1996); Reinhart and Rogoff(2009) and Laeven and Va lencia (2018), World Development Indicators. 


\section{B.3. Financial crises and international trade}

As a foretaste of the potential trade losses from crises, fig. 3 plots the cumulative change of trade flows from the year before the onset of each crisis to 5 -year ahead, scaled by pre-crisis GDP. The overall picture supports the collapse of international trade. Total exports and imports decline sharply during all types of financial crises (for example, exports and imports decline respectively by between 11 and 14 percentage points of pre-crisis GDP following all types of crises), mainly driven by the contraction of trade in manufactured goods, followed by the one in services, mining goods, and agricultural goods. In sum, the trade losses from financial crises seem important. However, various issues may lead to an overestimation of these losses. Consequently, we develop in the following a formal econometric analysis to provide a robust estimation of the trade losses from financial crises. In addition, Figure 3 shows that trade in emerging countries is dominated by manufactured goods, followed by trade in services, trade in mining goods, and finally trade in agricultural goods.

Figure 3: Evolution of the average international trade in financial crises

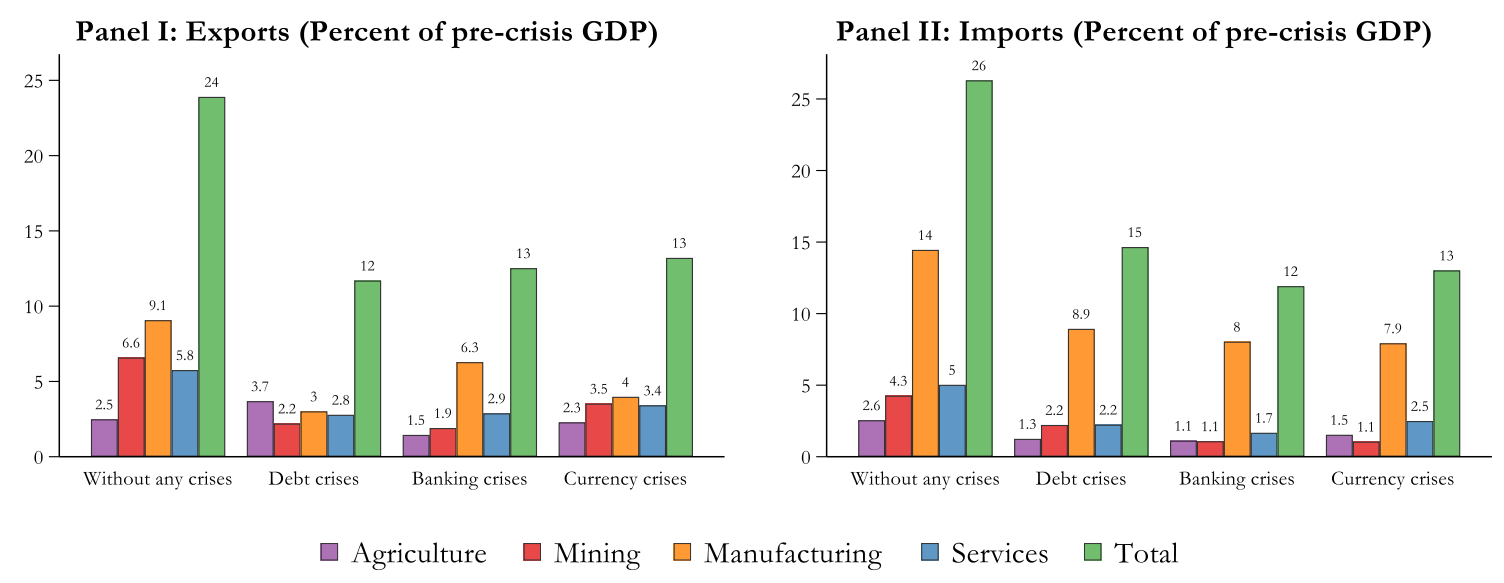

Notes: The figure plots the dependent variables of our empirical models for the horizon $\mathrm{h}=5$. The dependent va riables are 100 times the cumulative change of agricultural, mining, manufacturing, services, and total exports and imports rela tive to theyear before the onset of the crisis for years $1-5$ a fter the onset of the crisis, sca led pre-crisis GDP. The dependent variables a re plotted during debt, banking, and currency crises, and in the absence of crises. The first (second) row refers to exports (imports).

\section{RESULTS}

\section{A. Estimation of propensity scores}

As previously indicated, the first step of our analysis is devoted to the estimation of propensity scores (PS) for each crisis. We use the CBPS model that ensures a perfect 
balancing of covariates between countries with and without financial crises by using an optimization process ${ }^{16}$ Based on this model, fig. C. 2 in Appendix III. illustrates the smooth kernel density of the distribution of the PS for the treated and control groups, for each financial crisis. Given the high classification power, countries in the treated (control) group receive a high (low) likelihood of financial crises, while countries in the treated (control) group with PS close to zero (one) receive higher weights. Besides, fig. C.2 also shows considerable overlaps between the distributions of PS for the treated and control groups; thus, we weighted the covariates using PS. ${ }^{17}$ As shown by tables C.3 to C.5, there are many significant differences between countries with and without countries in the unweighted sample, with less favorable macroeconomic, external and institutional conditions in countries hit by crises. More importantly, we reveal that, according to the criteria of Rubin (2002), weighting the covariates by the estimated PS obtained from the CBPS model perfectly eliminates the differences in covariates between the treated and the control group (which is less true for the traditional pooled probit model, for example). Since our weighting strategy mimics a situation where financial crises occur randomly, it allows us to properly identify the ATE of crises.

\section{B. Financial crises and aggregated trade}

We first focus on aggregated trade, namely exports and imports, and then look at the trade balance. The ATE-AIPW estimates of the effects of financial crises on aggregated exports and imports are reported in table D.7, and their cumulative impulse responses are depicted in Panel I and II of fig. 4, respectively.

\footnotetext{
${ }^{16}$ In a nutshell, estimations show that: the likelihood of currency crises is increa sing with the occurrence of past-5 years debt and banking crises and decreasing with the level of development. Debt crises a re more likely when the level of public debt, financial openness, and the US interest rate increase. Banking crises are more likely when the levels of domestic credit and trading partners' growth increase and less likely when the level of liquid liabilities increa ses. The likelihood of debt and currency crises is decreasing with the level of foreign reserves and increasing in countries with floating exchange ra te regimes. Debtcrises a re less likely when trading partners' growth increases. Currency crises are less likely when tra de openness increases. Besides, standard dia gnostic tests reported a the bottom of the table show that our models presenta large cla ssification power (above 94 percent) and Area Under Receiver Operating Characteristic curve (a round 0.8 or more). For comparison, we a lso estimated a pooled model (reported in table D.6).

${ }^{17}$ Following Imbens (2004) and Cole and Hernán (2008), we truncate the maximum weight to 10 to reduce the influence of outliers on our ATE estimates. In the robustness a nalysis, we use a maximum weight of 5 and 20.
} 


\section{B.1. Exports}

The findings show that all types of financial crises reduce exports both on impact and cumulated over five years in countries affected by crises compared with those unaffected. As shown by Panel I of fig. 4, export losses are relatively small just after the occurrence of crises (except for currency crises), but then intensify and follow an L-shape. Exports' recovery from crises, i.e. return to pre-crisis level relative to GDP, if any, is a slow and uncertain process. The magnitude of this negative effect over 5 years is economically meaningful and equal to 5.6 percentage points (pp.) of pre-crisis GDP for debt crises, $7.7 \mathrm{pp}$. for currency crises and $8.9 \mathrm{pp}$. for banking crises.

\section{B.2. Imports}

Our findings confirm that imports are equally negatively affected by financial crises and do not recover over five years. As shown by Panel II of fig. 4, all types of crises exert significantly negative cumulated effects from the beginning of financial crises to five years later. Compared to exports, the magnitude of the adverse effects of financial crises on imports is more important and estimated at $9.1 \mathrm{pp}$. for currency crises, $11 \mathrm{pp}$. for debt crises, and 14 pp. for banking crises.

\section{B.3. Trade balance}

We look at the losses from financial crises on the trade balance by comparing their losses on exports and imports (see the bottom of table D.7 for the mean difference tests). We find that the trade balance increases for all years in the aftermath of debt and banking crises by more than $5 \mathrm{pp}$. of pre-crisis GDP, due to the stronger decrease in imports compared with exports. We find similar results for currency crises for the years 1-4 after the crises hit. However, currency crises are not found to significantly affect the trade balance the year 5 after their burst. Indeed, countries following crises will tend to reduce significantly imports than exports to restore or maintain their external viability. ${ }^{18}$

\footnotetext{
${ }^{18}$ Indeed, debt crises a re directly related to external viability, as they describe situations where governments fa ce difficulties to service or amortize their (external) debt. Similarly, currency crises mayjeopardize external viability through balance sheet effects, and in such circumstances, imports become more expensive. For banking crises, the linkage with external viability is less direct. We believe that import contraction to preserve or restore external via bility following banking crises could happen for two rea sons. First, th e credit crunch will compress consumptions, investments, exports (since it requires a lot of financing), a nd therefore theimport
}

(continued...) 
Figure 4: Cumulative trade losses over five years after financial crises

Panel I: Total Exports (percent of pre-crisis GDP)

(A) Debt Crises

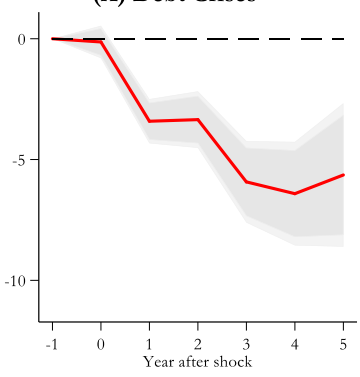

(B) Banking Crises

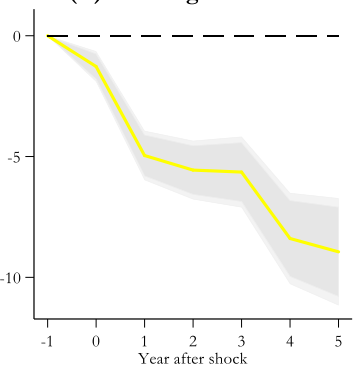

(C) Currency Crises

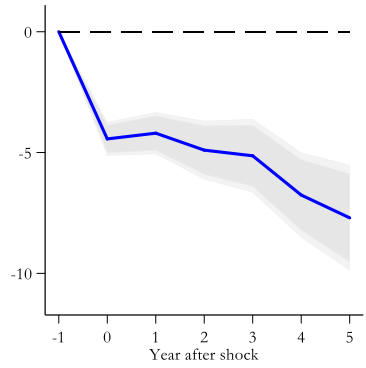

Panel II: Total Imports (percent of pre-crisis GDP)

(A) Debt Crises

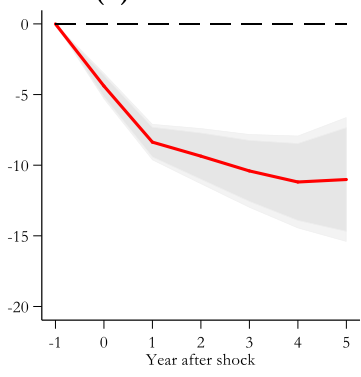

(B) Banking Crises

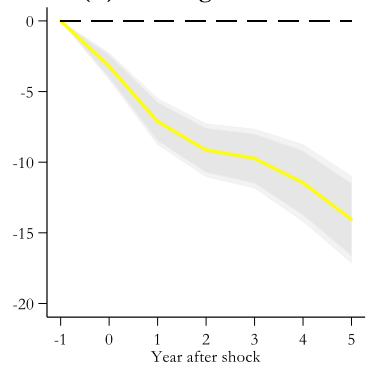

(C) Currency Crises

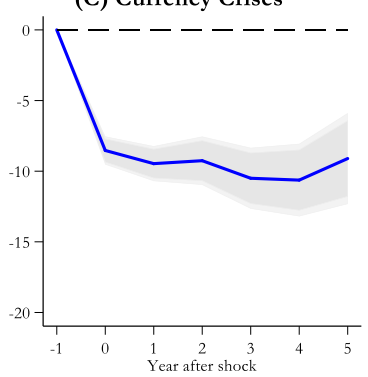

Notes: The Conditional cumulative change of total exports and imports from the start of the various crises (debt, banking, and currency). Ea ch colored path shows local projections of the cumulative change relative to the year before the onset of the crisis for years $1-5$ a fter the onset of the crisis. These losses describe the difference in the change of tra de between the treated and control groups after re-ra ndomization using the predicted propensity scores. The thinner and thicker bands are 90 and 95 percent confidence intervals, respectively. The top (bottom) row refers to the losses for exports (imports).

Summing up, at the aggregated level we find that financial crises reduce both the exports and imports of countries over five years, consistent with previous empirical findings.

Nevertheless, while some studies, see e.g. Abiad et al. (2014) and Kuvshinov and Zimmermann (2019), find no effect of debt and banking crises on exports, we reveal that exports sharply decline following these financial crises in line with Ma and Cheng(2005) and Asonuma et al. (2016). Besides, relative to Ma and Cheng (2005), we find that currency crises equally decrease exports, suggesting that the volume effect stemming from a gain of

contents of each. If exports collapse and trade or current a ccount deficit is increa sing, imports become more cha llenging to finance. Countries in such a situation may reduce imports to a lleviate the losses and a void the banking crisis to spill into other crises. Second, governments may decide to bailouts banks and therefore increa se their exposure to the underperforming banking sector. Sometimes, they do so by increasing their deficit, resulting in a twin deficit altering the confidence of creditors. As a result, "private" adjustments may be needed by reducing imports. 
competitiveness due to the local currency depreciation does not suffice to overcome the negative price effect. Moreover, currency crises tend to be associated with sudden stops in capital inflows which are necessary to trade (see, Bordo, 2006; Reinhart and Rogoff, 2009; Mendoza, 2010). ${ }^{19}$ Finally, there are several differences between crises: (i) banking crises exert the highest negative effect on both exports and imports, (ii) debt and banking crises induce a higher reduction in imports than exports, which increases the trade balance; (iii) currency crises have comparable losses on exports and imports in the year 5 after they occur. Keeping these results in mind as a benchmark, we look next at the effects of financial crises at a more disaggregated level.

\section{The sectoral trade losses from financial crises}

We explore the losses from financial crises on the trade of agricultural, mining, and manufactured goods, and services. As detailed in the introduction, this is, as far as we are aware, the first analysis that disentangles the aggregate trade losses from financial crises on all categories of goods and services traded. The estimated cumulative ATE over five years for exports and imports are reported in table D.7, and Panel I and II of fig. 5 provide a graphical illustration. ${ }^{20}$

\section{C.1. Agricultural trade}

We find that both exports and imports of agricultural goods are the least affected by financial crises. Countries that experience debt crises present larger exports of agricultural goods by $2.2 \mathrm{pp}$. of pre-crisis GDP over five years, compared with countries unaffected by crises. In contrast, exports of agricultural goods are left unchanged in the aftermath of currency crises or significantly decrease by $1.5 \mathrm{pp}$. over five years after the banking crises. Regarding agricultural imports, they are significantly reduced by between 0.6 and $1.5 \mathrm{pp}$. for all types of crises. These findings suggest that trade in agricultural goods exhibits greater resilience during financial crises and can even intensify, which may signal a substitution effect in favor

\footnotetext{
${ }^{19}$ Indeed, currency crises reduce financing for firms and have a strong negative impact on FX borrowers. An exa mple is the 1997 currency crisis in Indonesia. Many export firms had dollar-denominated short-term debt. When the crisis hit, foreign banks refused to rollover these loans. It ensued massive bankruptcies among exporters, which led to a drop in exports.

${ }^{20}$ To simplify the exposition, we focus more on the cumulated losses over five years (the dynamics of the losses from the onset of the financial crises until five years ahead a re also presented).
} 
of agricultural goods. Such an effect may be supported by the relatively lower income elasticity of demand for agricultural goods, which may also require less external financing to be produced and traded.

\section{C.2. Mining trade}

We reveal that, except for the positive effects of debt crises, the other financial crises significantly reduce the exports of mining goods. Indeed, five years after debt crises, exports of mining goods increase by $1.1 \mathrm{pp}$. of pre-crisis GDP. In the aftermath of banking and currency crises, exports of mining goods decrease both on impact and over the five years to reach a collapse of $1.6 \mathrm{pp}$. and $2.9 \mathrm{pp}$., respectively. After all types of crises hit the emerging countries, imports of mining goods over five years are also significantly reduced by $1.9 \mathrm{pp}$. for debt crises and $3 \mathrm{pp}$. for both banking and currency crises. Overall, the collapse of mining goods in the aftermath of financial crises is higher than the one of agriculture goods and sometimes lower sometimes higher than the one of trade in services, but more often largely lower than the collapse of the trade in manufactured goods.

Figure 5: Cumulative trade losses over five years after financial crises, total and sectoral level

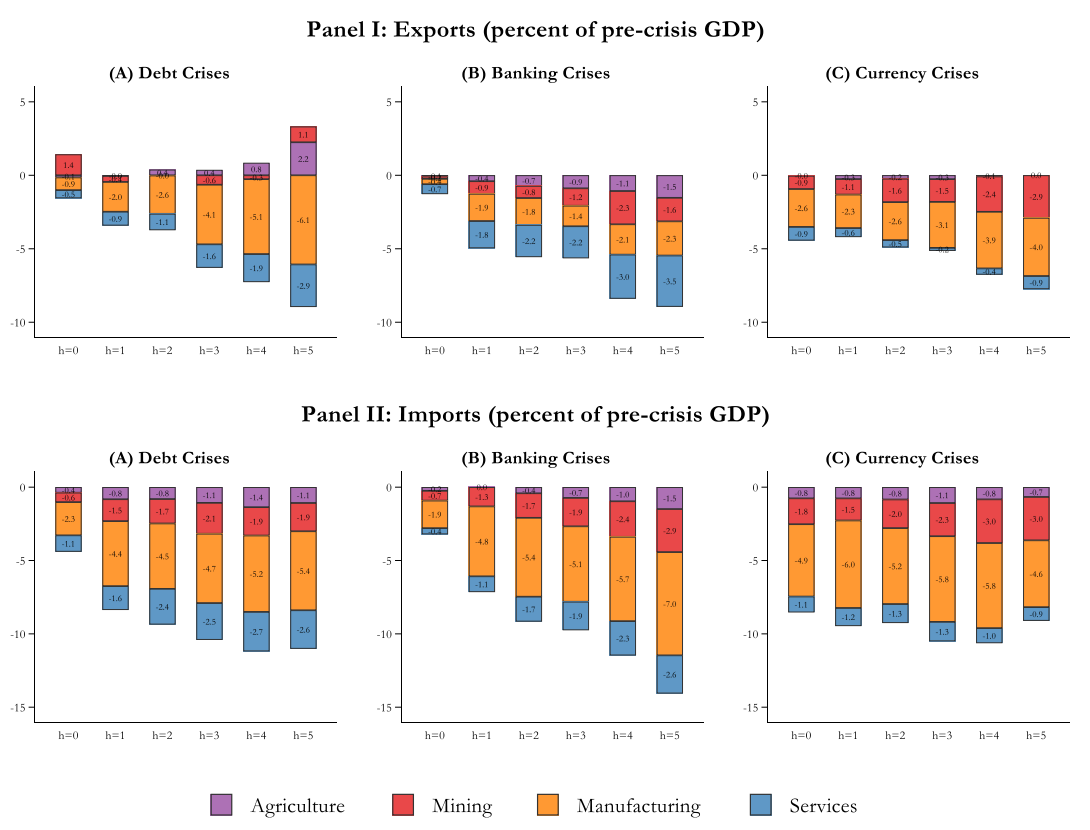

Notes: Robust standard errors clustered at the country-level in parentheses. AIPW estimates. The dependent variables are 100 times the cumulative change of agricultural, mining, manufacturing, and services exports and imports rela tive to the year prior to the onset of the crisis for years $1-5$ after the onset of the crisis, sca led precrisis GDP. Accumulated losses over five years. Maximum weights truncated at 10. 


\section{C.3. Manufacturing trade}

Our results point to a systematic and large reduction of the trade in manufactured goods in the aftermath of financial crises. The losses from financial crises on manufacturing exports are fairly important over five years and correspond to 6.1, 4 and 2.3 pp. of pre-crisis GDP for debt, currency, and banking crises, respectively. They are even higher for imports and equal to $4.6,5.4$, and $7 \mathrm{pp}$. for currency, debt, and banking crises, respectively. Besides, we note that except for the effects of banking crises on manufacturing exports, the collapse of manufactured trade contributes the most to the total drop of international trade in the aftermath of financial crises in emerging countries. These contributions equal to 107,51, and 26 percent of the total collapse of exports for debt, currency, and banking crises, respectively, and around 50 percent of the total collapse of imports for all types of crises. Moreover, as manufacturing imports fall more than manufacturing exports, the adverse effects of financial crises on the trade in manufactured goods are driven by the increase in overall trade balance highlighted for debt and banking crises. These findings are consistent with previous microlevel studies using data of manufacturing industries, including Iacovone and Zavaka (2009); Amiti and Weinstein (2011); Minetti and Zhu (2011); Chor and Manova (2012); Manova (2013); Zymek (2012) on the disruption channel, and Levchenko et al. (2010); Bricongne et al. (2012); Behrens et al. (2013); Eaton et al. (2016) on the income channel. However, despite revealing large effects of the occurrence of financial crises, the analysis of the trade of manufactured goods leaves unexplained a fairly large proportion of the trade losses at the aggregated level.

\section{C.4. Services trade}

Finally, similar to manufacturing trade, services trade is significantly reduced by all types of financial crises. We find that the losses from financial crises on trade in services are larger for exports and following banking crises; the losses reach $3.5 \mathrm{pp}$. of pre-crisis GDP over five years, or a contribution of 39 percent of the total export collapse. Also, exports contract in the aftermath of debt and currency crises by 2.9 and $0.9 \mathrm{pp}$. over five years. We find similar patterns for imports of services that are reduced by $2.6 \mathrm{pp}$. over five years following debt and banking crises and $0.9 \mathrm{pp}$. following currency crises. Therefore, compared with studies that focus on the trade of services following the global financial crises of 2008-09 (see e.g., Borchert and Mattoo, 2010; Ariu, 2016), we find that trade in services may also decline 
during crises. However, the trade of services presents a greater resilience compared with the trade of manufactured goods, except in the aftermath of banking crises, in line with the hypotheses of lower-income elasticity of demand and lower dependence on external financing.

To summarize, our sectoral analysis reveals that manufactured traded goods are the most affected in terms of magnitude in the aftermath of financial crises. However, the impact of financial crises on the other types of traded goods and services is far from being negligible. Trade in both mining goods and services also declines following several types of financial crises, while trade in agricultural goods seems to ben efit from a possible substitution effect, particularly following debt crises. In the following sections we discuss the robustness of our findings and emphasize the channels through which financial crises affect trade.

\section{ROBUSTNESS}

We further investigate the robustness of our findings using a wide variety of alternative specifications, including various samples, maximum weights in the treatment models, sources and definitions of crises, and econometric estimators.

\section{A. Alternative samples}

\section{A.1. The trade losses from combined financial crises}

The analysis performed so far focused on the effect of each financial crisis when controlling for the other types of crises in the prediction of the potential outcome and the computation of propensity scores. Given that financial crises seem to be connected (as shown previously), we now look at the trade effects of both combined and individual crises. Following Glick and Hutchison (2001) and Hutchison and Noy (2005), we define a combined crisis as a crisis occurring in a two-year band around a financial crisis of another type, i.e. a combined crisis occurs at time $t$ if another type of crisis occurs in any of the years spanning between $t-2$ and $t+2$. Similarly, an individual crisis is a crisis that occurs without any other crises in the years around.

The results reported in table D. 8 and fig. D. 3 show that combined financial crises trigger more significant and of a higher magnitude aggregated and sectoral trade losses, except for imports following debt crises. In addition, as shown by table D.9 and fig. D.4, the total and 
sectoral trade losses from individual financial crises are quite lower (more for exports than imports), except for imports following debt crises. Consequently, combined crises unveil more severe trade losses than individual crises, and studies that focus exclusively on a type of crisis without controlling for the others may suffer from an overestimation bias. In addition, our benchmark findings remain valid.

\section{A.2. Dropping the post-GFC period}

We drop the post-GFC period (from 2008 onwards) that incorporates the great trade collapse. The results are reported in table D.10 and fig. D.5. Removing this period leads to comparable results for the total and sectoral export losses from banking crises and currency crises, while the losses from debt crises are significantly reduced. In addition, the trade losses from financial crises on total and sectoral imports present a lower magnitude. Consequently, although the great trade collapse seems to have influenced the magnitude of the trade losses in some cases, our main results remain valid.

\section{B. Alternative maximum weights set in the treatment models}

Compared to the maximum weight of 10 for our treated and control groups used in the benchmark model, we now use a maximum weight of 20 in table D.11 and fig. D. 6 and 5 in table D.12 and fig. D.7. The choice of lower weights reduces the influence of country-year observations in the treated (control) group that receive a low (high) likelihood of financial crises. Estimations confirm the robustness of the significance and the size of the effect of financial crises on total and sectoral trade. In addition, the use of a maximum weight of 20 is associated with a somewhat lower magnitude of the trade losses only for some types of goods and financial crises. Overall, our main findings still hold when using alternative maximum weights, as recommended by Imbens (2004) and Cole and Hernán (2008).

\section{Alternative sources and definitions of crises}

Following Cruces and Trebesch (2013), debt crises now exclusively capture preemptive and post-default debt restructurings with private creditors (i.e. we drop restructurings with official creditors). Banking crises have the same definition but now come from the dataset of Reinhart and Rogoff (2009) (instead of Laeven and Valencia, 2018). Currency crises are redefined based on Reinhart and Rogoff (2009), namely by at least a 20 percent nominal depreciation of the local currency against the US dollar. Based on these new sources and 
definitions, our data now involves 41 debt crises, 44 banking crises, and 69 currency crises. Estimations reported in table D.13 and fig. D.8 show that, aside from lower trade losses for total and sectoral imports following debt and currency crises, our main findings still hold.

\section{ATE-IPW estimator}

Moving away from the Augmented Inverse Propensity Weighted (AIPW) estimator, we use the popular Inverse Propensity Weighted (IPW) estimator. The results presented in table D.14 and fig. D.9 are, aside from a lower magnitude especially for import trade losses, consistent with our main findings. Overall, this section confirms the robustness of our findings. Consequently, the next section is devoted to the analysis of the channels through which financial crises exert a negative effect on trade.

\section{Channels}

The existing literature on the channels through which financial crises impact international trade can be summarized into demand-side and supply-side factors. First, the demand-side argument sustains that the fall in income following crises hurts the demand of traded goods and services, especially in the aftermath of GFC (see, e.g. Freund, 2009; Levchenko et al., 2010; Bems et al., 2011; Bricongne et al., 2012; Behrens et al., 2013; Eaton et al., 2016; Abiad et al., 2014; Altomonte et al., 2014; Ariu, 2016). In this case, financial crises will differently affect the trade of agricultural, mining, and manufactured goods, and services, given their different income elasticity and degree of vertical linkages through global value chains. This channel may be more pronounced for imports and during times of generalized financial turmoil. Second, the supply-side argument suggests that financial crises are associated with significant reductions in the availability of external and trade finance (see, e.g. Iacovone and Zavaka, 2009; Amiti and Weinstein, 2011; Minetti and Zhu, 2011; Chor and Manova, 2012; Manova, 2013; Zymek, 2012). Consequently, financial crises will trigger different losses on the types of traded goods and services, given their different external financial needs.

Moving beyond this usual taxonomy, we believe that the two traditional channels can be supplemented by a third channel, namely the structural channel of financial crises on trade. We follow Beck (2002) and the standard assumption in international trade theory to assume that, unlike agricultural and mining goods, manufactured goods exhibit increasing returns to 
scale. Moreover, these products are relatively more credit-intensive, vertically integrated into global value chains, and their income elasticity is also higher, making them more vulnerable to financial crises. In addition, trade in services is mainly intermediate inputs (as shown by Miroudot et al., 2009), and they may require higher external finance compared to primary goods; therefore, they may also suffer more from financial crises. In contrast, countries that are specialized in the export of manufacturing goods or are diversified in terms of exports and/or partners may have a stronger resilience to crises, making total trade and the trade of manufactured goods to be less disrupted by crises (see also, Romeu and da Costa Neto, 2011; Abreha et al., 2020). Therefore, the structural channel is likely to capture two opposite effects: the vulnerability and the resilience of trade, and our estimations aims at identifying which one of them is dominant.

To assess the potential role of the different channels in shaping the trade costs of financial crises, we split our initial dummies of financial crises in two identical parts, along with the variables used as proxies for the channels. We use the median of these variables at the start of each financial crisis to have enough observations for both groups. First, we proxy the structural channel by the share of manufactured exports in total exports, an export diversification index, and a trading partners diversification index measured the year before the crises. Second, we proxy the demand-side channel by the evolution of trading partners' growth rate over the five years following crises. Third, we proxy the supply-side channel by the evolution of financial development, gross capital inflows, and investors' credit rating risks over the five years following crises. ${ }^{21}$ The evolution of the variable $\mathrm{x}$ over the five years following financial crises is computed as

$$
x_{t+5, t+1}=\frac{1}{5} \sum_{n=0}^{5}\left(x_{t+n}-x_{t+1}\right)
$$

As in the benchmark model, we estimate treatment models for the likelihood of financial crises, as well as the outcome models for the financial crises, above and below the median of

\footnotetext{
${ }^{21}$ Therefore, we can identify financial crises with and without a higher share of manufacturing exports, export diversifica tion, tra ding partners diversification for the compositional and structural channel; financial crises with or without a higher trading partners' growth for the demand-side channel; financial crises with or without a higher increa se of financial development, gross ca pital inflows, and investors' credit ra ting risks for the supply side channel.
} 
the channel variables, separately. Subsequently, we compute the ATE-AIPW estimates of the effect of financial crises above and below the median of the channel variables. For simplicity, our interpretations focus on the 5-year cumulated effects of financial crises.

\section{A. The structural channel}

We analyze the trade losses from financial crises in countries with a high and low share of manufacturing exports the year before the beginning of crises, in order to capture the differentiated effects of financial crises in countries with different export structure. Estimations reported in fig. D.10 and tables A.15a to A.15c show that total, manufacturing, and services exports and imports fall more after crises in countries with a lower (pre-crisis) share of manufacturing exports. In addition, the trade in agricultural and mining goods displays similar patterns across the two groups of countries. Consequently, countries with a higher share of manufacturing exports are more resilient to financial crises: in these countries, the resilience effect dominates the vulnerability effect. Financial crises act as an impediment to structural transformation for countries relying on primary goods, and reinforce their comparative advantage in primary goods by disrupting more their manufacturing and services trade structure. ${ }^{22}$

Second, we investigate the role of export diversification in shaping the trade losses from financial crises. To do so, we create two groups of financial crises with high and low export diversification the year before crises. Estimations presented in fig. D.11 and tables A.16a to A.16c reveal that financial crises generally lead to higher contraction of total, manufacturing, and services trade in countries with lower export diversification. These contractions are driven by the fall of manufacturing trade, except for exports following banking crises. Therefore, countries with a more diversified export structure will suffer less from financial crises, i.e. diversification strengthens the resilience of international trade to financial crises.

Third, we study the effects of financial crises in countries with high and low trading partners' diversification the year before crises. By doing so, we check whether having a diversified number of trading partners' helps alleviating the trade losses from financial crises.

\footnotetext{
${ }^{22}$ Note that our benchmark results, involving a total tra de collapse driven by the fall of manufacturing and services trade, remain valid.
} 
Estimations reported in fig. D.12 and tables A.17a to A.17c show that, except for banking crises, countries with more trading partners experience a lower adverse effect on their trade in the aftermath of debt and currency crises; thus, diversifying trading partners may help to significantly reduce the trade losses from financial crises, and increase the resilience of trade to crises.

Overall, the proxy variables show that the structure of trade, its diversification in terms of exported products, and trading partners matter for the losses from financial crises on trade, and the resilience of trade. We find that trade is more reduced in countries with a lower share of manufacturing exports, diversified exported products, and trading partners. These findings sustain that financial crises may act as an impediment to structural transformations, as they hurt more manufacturing exports in countries where the share of manufacturing exports is relatively lower. Besides, by diversifying their exports and partners, countries will increase their resilience to financial crises.

\section{B. The demand-side channel}

We explore the demand-side channel using as a proxy the trading partners' growth. We identify two sets of financial crises with high and low trading partners' growth. We expect higher trading partners' growth to be negatively associated with the reduction of both exports and imports, since the contraction of income may be lower in this case. Estimations reported in fig. D.13 and tables A.18a to A.18c confirm that, when associated with higher trading partners' growth, financial crises have either a milder or no adverse effect on international trade, except for banking crises. In particular, no effect is found for debt crises on either exports or imports, because of a large increase of agriculture and mining exports that offsets the collapse of manufacturing and services trade, and a small fall of agriculture and services imports that is compensated by the small increase of mining imports. In the aftermath of currency crises, the higher reduction of exports and imports in countries with lower trading partners' growth is driven by the fall of all types of goods and services, except for agriculture exports. In contrast, banking crises lead to similar or slightly higher trade losses when associated with higher trading partners' growth. 
In sum, financial crises associated with a lower demand for goods and services from trading partners will have more adverse trade losses; at the global level, such dynamics may result into an unprecedented collapse of international trade, as the one witnessed in the post-GFC period.

\section{The supply-side channel}

We relate the supply-side channel to the availability of external financing, which is particularly needed during periods of financial turmoil. First, we look at the credit channel using the evolution of financial development in the aftermath of financial crises, by distinguishing between crises associated with and without a high increase in financial development. Estimations presented in fig. D.14 and tables A.19a to A.19c suggest all types of financial crises associated with a low increase (or a contraction) of financial development lead to a higher decline of trade. These findings reinforce the idea that financial crises drive the collapse of trade because of their disruptive effects on the monetary and financial sector. Second, aside from domestic financial development, international trade also depends on the ability to access external or trade credit from other countries, or attract foreign direct investments; besides, financial crises are very often associated with sudden stops or capital reversals (see, e.g. Bordo, 2006; Reinhart and Rogoff, 2009; Mendoza, 2010). Therefore, we investigate the potential role played by the evolution of gross capital inflows in shaping the dynamics of the trade losses from financial crises. Estimations shown in fig. D.15 and tables A.20a to A.20c confirm that all types of financial crises associated with a large reduction of gross capital inflows generate a stronger reduction of total and sectoral trade compared to crises with milder reduction (or increase) in gross capital inflows. This trade reduction trade is driven by the fall of manufacturing exports for debt and currency crises, service exports for banking crises, and manufacturing imports for all crises.

Finally, we look at the evolution of investors' credit ratings risks as a proxy of the international financial conditions and the losses from borrowing. Estimations presented in fig. D.16 and tables A.20a to A.20c show that, when associated with a higher deterioration of investors' sentiment, financial crises mostly trigger a detrimental effect on total and sectoral trade, compared with crises associated with a lower reduction (or increase) in investors' credit ratings risks. 
Overall, the supply-side channel influences the way financial crises shape the dynamics of international trade. When associated with a deterioration of the domestic financial development and external financial conditions, and sudden stops, financial crises reduce international trade, mainly acting through manufacturing and services trade.

\section{CONCLUDING REMARKS}

This paper assesses the sectoral trade losses from financial crises. Compared with the existing literature that mainly focuses on the total trade of goods and, in the context of the recent great recession, on manufacturing trade, we look at the response of different types of trade (i.e. agricultural, mining, and manufactured goods, and services) following various types of financial crises (i.e. debt, banking, and currency crises). To this end, we draw upon a methodology that combines impact assessment and local projections to capture a causal dynamic effect running from financial crises to the trade activity.

While we confirm that aggregate exports and imports significantly decrease following most financial crises, our analysis reveals interesting patterns at the disaggregated level. Manufacturing goods are the most affected by financial crises. However, the impact of financial crises on the other types of traded goods and especially on services is far from being negligible. Trade in both mining goods and services also declines following several types of financial crises, while trade in agricultural goods seems to benefit from a possible substitution effect particularly following debt crises. When looking at the losses from combined crises, we find that they exert a significant and higher decline of trade, compared to crises occurring without any other crisis in the years around. These findings are robust to a wide variety of alternative samples, maximum weights in the treatment models, sources and definitions of crises, and estimators.

In addition, we provide new evidence that financial crises negatively affect trade through three channels: a structural, a demand-side, and a supply-side channel. First, regarding the structural channel, we find that financial crises may act as an impediment of structural transformation, as they hurt more manufacturing exports in countries where the share of manufacturing exports is relatively lower; besides, by diversifying their exports and partners, countries may increase their resilience to financial crises. Second, regarding the demand-side 
channel, financial crises associated with a lower demand of goods and services from trading partners experience higher trade losses. Third, regarding the supply-side channel, when associated with a deterioration of the domestic financial development and external financial conditions, and sudden stops, financial crises induce higher international trade losses. Policy implications from our findings are that diversification of exports, trading partners, and improvements of financial development increase the resilience of trade to financial crises. Moreover, policies needed to reduce the occurrence of financial crises and increase creditors' confidence, i.e., sound macroeconomic policies, macroprudential policies, multilateral policies coping with the contagion of crises, may help to alleviate the trade losses from financial crises, specifically in countries with lower industrialization where crises are found to impede structural transformations.

Consequently, our paper unveils the complex panorama of the trade losses from financial crises. Through illustrating the differentiated effects of various financial crises on sectoral and total international trade, and by investigating the channels through which these effects transit, our analysis contributes to the general understanding of the trade effects of financial crises, and provides insightful support for the design and implementation of policies aimed at coping with these effects. 


\section{REFERENCES}

Abiad, A., P. Mishra, And P. Topalova (2014): "How does trade evolve in the aftermath of financial crises?" IMF Economic Review, 62, 213-247.

Abreha, K. G., V. Smeets, And F. Warzynski (2020): "Coping with the crisis and export diversification," World Economy, 43, 1452-1481.

Altomonte, C., F. Di Mauro, G. Ottaviano, A. Rungi, And V. Vicard (2014): Global Value Chains during the Great Trade Collapse.

Amiti, M. And D. Weinstein (2011): “Exports and financial shocks," Quarterly Journal of Economics, 126, 1841-1877.

Ariu, A. (2016): "Crisis-proof services: Why trade in services did not suffer during the 20082009 collapse,” Journal of International Economics, 98, 138-149.

Asonuma, T., M. Chamon, And A. Sasahara (2016): "Trade Costs of Sovereign Debt Restructurings: Does a Market-Friendly Approach Improve the Outcome?" IMF Working Paper No. 16/222.

Auerbach, A. And Y. Gorodnichenko (2012a): "Measuring the output responses to fiscal policy,” American Economic Journal: Economic Policy, 4, 1-27.

Auerbach, A. J. And Y. Gorodnichenko (2012b): Fiscal Multipliers in Recession and Expansion, University of Chicago Press.

Baldwin, R. (2011): The Great Trade Collapse: Causes, Consequences and Prospects, Centre for Economic Policy Research.

Beck, T. (2002): "Financial development and international trade: Is there a link?" Journal of International Economics, 57, 107-131.

Beck, T. And A. Demirguc-Kunt (2009): "Financial Institutions and Markets Across

Countries And Over Time - Data And Analysis," World Bank Policy Research Working Paper No. 4943.

Behrens, K., G. Corcos, And G. Mion (2013): “Trade crisis? What trade crisis?” Review of Economics and Statistics, 95, 702-709. 
Bems, R., R. C. Johnson, And K. M. Yi (2011): "Vertical linkages and the collapse of global trade," American Economic Review, 101, 308-312.

Berman, N. And P. Martin (2012): "The vulnerability of Sub-Saharan Africa to financial crises: The case of trade," IMF Economic Review, 60, 329-364.

Bernard, A. And B. Jensen (1999): "Exceptional exporter performance: cause, effect, or both?" Journal of International Economics, 47, 1-25.

Borchert, I. And A. Mattoo (2010): “The crisis-resilience of services trade,” Service Industries Journal, 30, 2115-2136.

Bordo, M. D. (2006): “Sudden Stops Financial Crises and Original Sin in Emerging Countries: Deja Vu?" NBER Working Paper No. 12393, 1-36.

Bricongne, J. C., L. Fontagne, G. Gaulier, D. Taglioni, And V. Vicard (2012): “Firms and the global crisis: French exports in the turmoil," Journal of International Economics, 87, 134-146.

Burstein, A. And J. Cravino (2015): "Measured aggregate gains from international trade," American Economic Journal: Macroeconomics, 7, 181-218.

Chinn, M. D. And H. Ito (2008): “A New Measure of Financial Openness,” Journal of Comparative Policy Analysis: Research and Practice, 10,309-322.

Chor, D. And K. Manova (2012): "Off the cliff and back? Credit conditions and international trade during the global financial crisis," Journal of International Economics, 87, 117-133.

Cole, S. And M. Hernan (2008): "Constructing inverse probability weights for marginal structural models," American Journal of Epidemiology, 168, 656-664.

Cruces, J. And C. Trebesch (2013): "Sovereign defaults: The price of haircuts," American Economic Journal: Macroeconomics, 5, 85-117.

Dollar, D. (1992): “Outward-Oriented Developing Economies Really Do Grow More Rapidly: Evidence from 95 LDCs, 1976-1985," Economic Development and Cultural Change, 40, 523-544.

Eaton, J., S. Kortum, B. Neiman, And J. Romalis (2016): “Trade and the global recession," American Economic Review, 106, 3401-3438. 
Edmond, C., V. Midrigan, And D. Xu (2015): "Competition, markups, and the gains from international trade," American Economic Review, 105, 3183-3221.

Edwards, S. (1998): “Openness, productivity and growth: What do we really know?" The Economic Journal, 108,383-398.

Eichengreen, B. And A. Rose (1999): "Contagious Currency Crises: Channels of Conveyance," Changes in Exchange Rates in Rapidly Developing Countries: Theory, Practice, and Policy Issues (NBER book), 7.

Feyrer, J. (2009a): "Distance, Trade, and Income: The 1967 to 1975 Closing of the Suez Canal as a Natural Experiment," NBER Working Paper No. w, 1-31.

_ (2009b): "Trade and Income -Exploiting Time Series in Geography," SSRN Electronic Journal.

Forbes, K. (2001): “Are Trade Linkages Important Determinants of Country Vulnerability to Crises?” NBER Working Paper No. 8194.

Forni, L., C. Richmond, G. Palomba, And J. Pereira (2016): “Sovereign Debt Restructuring and Growth," IMF Working Paper No. 16/147, 16, 1.

Frankel, J. A. And D. Romer (1999): “Does trade cause growth?” American Economic Review, 89, 379-399.

Frankel, J. A. And A. K. Rose (1996): “Currency crashes in emerging markets: An empirical treatment," Journal of International Economics, 41, 351-366.

Freund, C. (2009): “The Trade Response to Global Downturns: Historical Evidence,” World Bank Policy Research Working Paper No. 5015.

Glick, R. And M. Hutchison (2001): "Banking and Currency Crises: How Common Are Twins?" University of California Santa Cruz, Department of Economics Working Paper No. 488.

Glick, R. And A. K. Rose (1999): “Contagion and trade: Why are currency crises regional?" Journal of International Money and Finance, 18, 603-617.

Glynn, A. And K. Quinn (2009): “An introduction to the augmented inverse propensity weighted estimator," Political Analysis, 18, 36-56. 
Hutchison, M. M. And I. Noy (2005): “How Bad are Twins? Output Costs of Currency and Banking Crises," SSRN Electronic Journal, 37, 725-752.

Iacovone, L. And V. Zavaka (2009): "Banking Crises and Exports Lessons from the Past," World Bank Policy Research Working Paper No. 5016.

Ilzetzki, E., C. Reinhart, And K. Rogoff (2017): “The Country Chronologies to Exchange Rate Arrangements into the 21 st Century: Will the Anchor Currency Hold?"NBER Working Paper No. 23135.

Imai, K. And M. Ratkovic (2014): “Covariate balancing propensity score," Journal of the Royal Statistical Society. Series B: Statistical Methodology, 76, 243-263.

Imbens, G. (2004): "Nonparametric estimation of average treatment effects under exogeneity: A review," Review of Economics and statistics, 86, 4-29.

Johns, B., M. Brenton, M. Cali, M. Hoppe, And R. Piermartini (2015): "The role of trade in ending poverty," World Bank and World Trade Organization report No. 97607: Geneva. Jorda, O. (2005): “Estimation and inference of impulse responses by local projections," American Economic Review, 95, 161-182.

Jorda, O., M. Schularick, And A. M. Taylor (2016): "Sovereigns versus banks: Credit, crises, and consequences," Journal of the European Economic Association, 14, 45-79.

Kreif, N., R. Grieve, R. Radice, And J. Sekhon (2013): "Regression-adjusted matching and double-robust methods for estimating average treatment effects in health economic evaluation," Health Services and Outcomes Research Methodology, 13, 174-202. Krugman, P. (1979): “A Model of Balance-of-Payments Crises,” Journal of Money, Credit and Banking, 11, 311-325.

Kuvshinov, D. And K. Zimmermann (2019): "Sovereigns going bust: Estimating the cost of default," European Economic Review, 119, 1-21.

Laeven, L. And F. Valencia (2018): “Systemic Banking Crises Revisited,” IMF Working paper No. 18/206, 18.

Leon, S., A. Tsiatis, And M. Davidian (2003): "Semiparametric Estimation of Treatment Effect in a Pretest-Posttest Study," Biometrics, 59, 1046-1055. 
Levchenko, A. A., L. T. Lewis, And L. L. Tesar (2010): "The collapse of international trade during the 2008-09 crisis: In search of the smoking gun,” IMF Economic Review, 58, 214 253.

Lunceford, J. K. And M. Davidian (2004): "Stratification and weighting via the propensity score in estimation of causal treatment effects: A comparative study," Statistics in Medicine, 23, 2937-2960.

Ma, Z. And L. Cheng (2005): "The Effects of Financial Crises on International Trade," NBER Working Paper No. 10172.

Manova, K. (2013): "Credit constraints, heterogeneous firms, and international trade," Review of Economic Studies, 80, 711-744.

Martinez, J. And G. Sandleris (2011): "Is it punishment? sovereign defaults and the decline in trade," Journal of International Money and Finance, 30,909-930.

Mbaye, S., M. Moreno Badia, And K. Chae (2018): “Global Debt Database: Methodology and Sources," IMF Working Papers, 18, 1.

Mendoza, E. G. (2010): "Sudden Stops, financial crises, and leverage," American Economic Review, 100, 1941-1966.

Minetti, R. And S. C. Zhu (2011): "Credit constraints and firm export: Microeconomic evidence from Italy,” Journal of International Economics, 83, 109-125.

Miroudot, S., A. Ragoussis, And R. Lanz (2009): “Trade in Intermediate Goods and Services," OECD Trade Policy Papers, 1-66.

Owyang, M., V. Ramey, And S. Zubairy (2013): “Are government spending multipliers greater during periods of slack? Evidence from twentieth-century historical data," American Economic Review, 103, 129-134.

Pavcnik, N. (2002): "Trade Liberalization, Exit and Productivity Improvements: Evidence from Chilean Plants," Review of Economic Studies, 69, 245-276.

Reinhart, C. M. And K. S. Rogoff (2009): This time is different: eight centuries of financial folly, Princeton University Press. 
Rodriguez, F. And D. Rodrik (2000): “Trade policy and economic growth: A skeptic's guide to the cross-national evidence," NBER Macroeconomics Annual, 15, 228-325.

Romeu, R. And N. C. Da Costa Neto (2011): "Did Export Diversification Soften the Impact of the Global Financial Crisis?” IMF Working Papers No. 11/99, 11, 1. 36

Rose, A. (2005): “One reason countries pay their debts: Renegotiation and international trade," Journal of Development Economics, 77, 189-206.

Rosenbaum, P. And D. Rubin (1983): “The central role of the propensity score in observational studies for causal effects," Biometrika, 70, 41-55.

Rubin, D. (2002): “Using propensity scores to help design observational studies: Application to the tobacco litigation," Health Services and Outcomes Research Methodology, 2, 169188.

Sachs, J. And A. Warner (1995): "Economic Reform and the Process of Global Integration," Brookings Papers on Economic Activity, 26, 1-118.

Trefler, D. (2004): “The long and short of the Canada-U.S. free trade agreement," American Economic Review, 94, 870-895.

Tsiatis, A. And M. Davidian (2007): “Comment: Demystifying double robustness: A comparison of alternative strategies for estimating a population mean from incomplete data," Statistical Science, 22, 540-543.

Wooldridge, J. (2007): "Inverse probability weighted estimation for general missing data problems," Journal of Econometrics, 141, 1281-1301.

Zymek, R. (2012): “Sovereign default, international lending, and trade," IMF Economic Review, 60, 365-394. 


\section{APPENDIX I. SAMPLE, VARIABLES DESCRIPTIONS AND SOURCES}

\section{A. Financial crises since 1980 in all emerging countries}

Figure A.1: Sample of countries and the starting date of the various financial crises since 1980

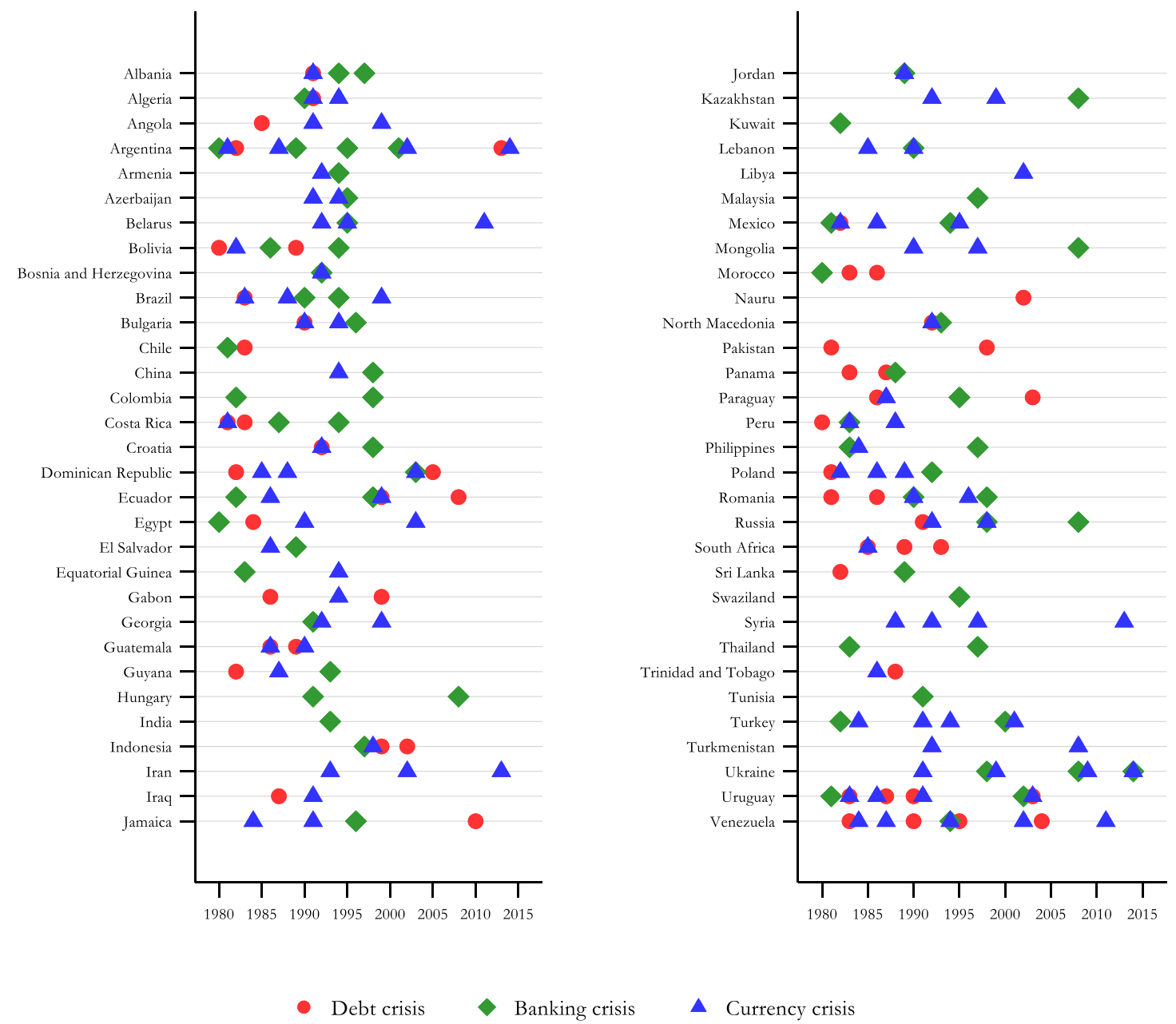

Notes: The graph reports the starting da te of the various crises since 1980 in all emerging countries.

\section{B. List of countries included in regressions analyses}

Albania, Algeria, Argentina, Armenia, Bolivia, Brazil, Chile, China, Colombia, Costa Rica, Croatia, Dominican Republic, Ecuador, Egypt, Arab Rep., Gabon, Georgia, Guatemala, Hungary, India, Indonesia, Jamaica, Jordan, Lebanon, Mexico, Morocco, Pakistan, Panama, Paraguay, Peru, Philippines, Poland, Romania, Russian Federation, South Africa, Sri Lanka, Thailand, Tunisia, Turkey, Ukraine, Uruguay, Venezuela. 


\section{Data description and sources}

\section{Table A.1: Data sources and descriptions}

\begin{tabular}{|c|c|}
\hline Variables & Sources \\
\hline \multicolumn{2}{|c|}{ Trade variables } \\
\hline International trade in goods (agricultural, mining & World Integrated Trade Solution (WITS) code at 3-digit SITC classification \\
\hline International trade in services & United Nations Conference on Trade and Development (UNCTAD) \\
\hline $\begin{array}{l}\text { Cumulative change of trade variables from the } \\
\text { onset of financial crises to years } 1-5 \text { after crises, }\end{array}$ & Authors' calculation based in WITS and UNCTAD \\
\hline \multicolumn{2}{|l|}{ Financial crises } \\
\hline Debt crises & Reinhart and Rogoff (2009) and Cruces and Trebesch (2013) \\
\hline Banking crises & Laeven and Valencia (2018) and Reinhart and Rogoff (2009) \\
\hline Currency crises & $\begin{array}{l}\text { Authors' calculation based on exchange rate taken from Penn World Tables } 9.0 \\
\text { and Bruegel datasets, and using the definition in Frankel and Rose (1996) and }\end{array}$ \\
\hline \multicolumn{2}{|r|}{ 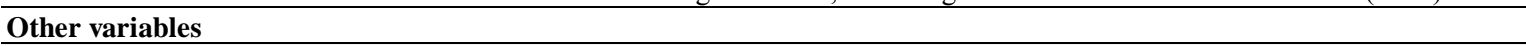 } \\
\hline Intensity of conflicts & Major episodes of political violence (MEPV) \\
\hline Log of real GDP & World Development Indicators \\
\hline Log. of public debt to GDP & Global Debt Database of the IMF (Mbaye et al. (2018)) \\
\hline Log. of domestic credit to GDP & World Economic Outlook, IMF, and World Development Indicators, WB \\
\hline Log. of liquid liabilities to GDP & Beck and Demirguc-Kunt (2009) \\
\hline Net capital inflows to GDP & $\begin{array}{l}\text { Authors' calculations based on the Balance of Payments and International } \\
\text { Investment Position dataset from the IMF }\end{array}$ \\
\hline Gross Capital inflows ( $\%$ of GDP) & $\begin{array}{l}\text { Authors' calculations based on the Balance of Payments and International } \\
\text { Investment Position dataset from the IMF }\end{array}$ \\
\hline Log. of foreign reserves to GDP & World Economic Outlook, IMF, and World Development Indicators, WB \\
\hline Current account to GDP & World Economic Outlook, IMF, and World Development Indicators, WB \\
\hline Financial openness index & Chinn and Ito (2008) \\
\hline Log of trade openness to GDP & World Development Indicators \\
\hline Terms of trade growth & Penn World Tables 9.1 \\
\hline Floating exchange rate regime & Authors' calculation based on Ilzetzki et al. (2017) \\
\hline Government accountability index & Varieties of Democracy (V-Dem) project \\
\hline Corruption index & Varieties of Democracy (V-Dem) project \\
\hline Trading partners' growth & Global Economic Environment, IMF \\
\hline US interest rate on gov.'s debt securities & Bank of International Settlements \\
\hline Exports diversification index & Export Diversification and Quality database, IMF \\
\hline Trading partners diversification index & Export Diversification and Quality database, IMF \\
\hline Financial development index & Financial development index from IMF \\
\hline Investors' credit ratings risks & Country Credit Ratings from the IMF \\
\hline
\end{tabular}


APPENDIX II.SUMMARY STATISTICS

Table B.2: Summary statistics for major variables

\begin{tabular}{|c|c|c|c|c|c|}
\hline & Obs. & Mean & Sd & Min & Max \\
\hline Cumulative change of total exports over 5 years (\% of pre-crisis GDP) & 766 & 19.690 & 20.795 & -18.277 & 124.255 \\
\hline Cumulative change of agricultural mining exports over 5 years ( $\%$ of pre-crisis GDP) & 766 & 2.646 & 3.923 & -2.543 & 44.719 \\
\hline Cumulative change of mining exports over 5 years ( $\%$ of pre-crisis GDP) & 766 & 3.291 & 8.324 & -18.363 & 72.770 \\
\hline Cumulative change of manufacturing exports over 5 years ( $\%$ of pre-crisis GDP) & 766 & 8.362 & 13.009 & -11.702 & 94.118 \\
\hline Cumulative change of services exports over 5 years ( $\%$ of pre-crisis GDP) & 766 & 5.392 & 7.282 & -9.869 & 49.547 \\
\hline Cumulative change of imports over 5 years (\% of pre-crisis GDP) & 766 & 23.338 & 27.805 & -20.333 & 179.063 \\
\hline Cumulative change of agricultural mining imports over 5 years (\% of pre-crisis GDP) & 766 & 2.228 & 3.039 & -4.678 & 25.207 \\
\hline Cumulative change of mining imports over 5 years (\% of pre-crisis GDP) & 766 & 3.819 & 5.958 & -10.939 & 34.175 \\
\hline Cumulative change of manufacturing imports over 5 years (\% of pre-crisis GDP) & 766 & 13.219 & 16.641 & -20.028 & 102.713 \\
\hline Cumulative change of services imports over 5 years (\% of pre-crisis GDP) & 766 & 4.072 & 5.516 & -4.676 & 40.976 \\
\hline Share of agricultural exports ( $\%$ of total exports) & 766 & 19.128 & 15.711 & 0.160 & 71.509 \\
\hline Share of mining exports (\% of total exports) & 766 & 17.572 & 21.172 & 0.001 & 95.987 \\
\hline Share of manufacturing exports (\% of total exports) & 766 & 34.545 & 21.392 & 0.306 & 86.902 \\
\hline Share of services exports (\% of total exports) & 766 & 28.755 & 19.331 & 2.558 & 90.934 \\
\hline Share of agricultural imports (\% of total imports) & 766 & 10.474 & 4.338 & 2.797 & 30.705 \\
\hline Share of mining imports (\% of total imports) & 766 & 13.775 & 7.875 & 0.804 & 46.405 \\
\hline Share of manufacturing imports (\% of total imports) & 766 & 55.141 & 10.704 & 26.701 & 80.015 \\
\hline Share of services imports (\% of total imports) & 766 & 20.610 & 7.227 & 5.017 & 49.055 \\
\hline 1 if Debt crises at start & 766 & 0.052 & 0.223 & 0.000 & 1.000 \\
\hline 1 if Banking crises at start & 766 & 0.048 & 0.215 & 0.000 & 1.000 \\
\hline 1 if Currency crises at start & 766 & 0.050 & 0.217 & 0.000 & 1.000 \\
\hline Intensity of conflicts & 766 & 1.219 & 2.227 & 0.000 & 10.000 \\
\hline Log of real GDP & 766 & 7.212 & 3.687 & -8.147 & 15.742 \\
\hline Log. of public debt to GDP & 765 & 3.661 & 0.696 & 0.991 & 5.355 \\
\hline Log. of domestic credit to GDP & 757 & 3.484 & 0.653 & 1.380 & 5.076 \\
\hline Log. of liquid liabilities to GDP & 760 & 3.635 & 0.573 & 1.687 & 5.482 \\
\hline Net capital inflows to GDP & 745 & 2.531 & 5.075 & -22.404 & 24.586 \\
\hline Log. of foreign reserves to GDP & 766 & 2.201 & 0.863 & -1.138 & 4.677 \\
\hline Current account to GDP & 766 & -2.588 & 5.050 & -29.363 & 22.671 \\
\hline Financial openness index & 765 & 0.469 & 0.336 & 0.000 & 1.000 \\
\hline Log of trade openness to GDP & 766 & 4.021 & 0.493 & 2.446 & 5.116 \\
\hline Terms of trade growth $(\%)$ & 766 & 0.005 & 0.053 & -0.323 & 0.360 \\
\hline Floating exchange rate regime & 766 & 0.110 & 0.313 & 0.000 & 1.000 \\
\hline Government accountability index & 766 & 0.647 & 0.827 & -1.529 & 1.986 \\
\hline Corruption index & 766 & -0.589 & 0.250 & -0.960 & -0.037 \\
\hline Trading partners' growth $(\%)$ & 751 & 3.607 & 2.034 & -4.810 & 13.262 \\
\hline US interest rate on gov.'s debt securities (\%) & 766 & 4.847 & 4.159 & 0.125 & 22.000 \\
\hline Exports diversification index & 728 & 2.840 & 0.793 & 1.498 & 5.558 \\
\hline Trading partners diversification index & 728 & 2.657 & 0.550 & 1.651 & 4.614 \\
\hline Financial development index & 766 & 0.279 & 0.121 & 0.061 & 0.632 \\
\hline Investors' credit ratings risks & 761 & 42.797 & 14.103 & 7.650 & 81.050 \\
\hline
\end{tabular}




\section{APPENDIX III. BALANCE AND OVERLAP CHECKS}

\section{A. Balance checks}

Table C.3: Balance diagnostics between the treated and control groups, Debt crises

\begin{tabular}{|c|c|c|c|c|c|c|c|c|c|c|c|c|}
\hline \multicolumn{13}{|c|}{ Debt crises } \\
\hline \multirow[b]{3}{*}{ Variables } & \multicolumn{4}{|c|}{ (1) Non weighted } & \multicolumn{8}{|c|}{ (2) Weighted } \\
\hline & \multirow[b]{2}{*}{ Treated } & \multirow[b]{2}{*}{ Control } & \multirow[b]{2}{*}{ Std. mean } & \multirow[b]{2}{*}{ Var. ratio } & \multicolumn{4}{|c|}{ (21) Covariate Balancing propensity score } & \multicolumn{4}{|c|}{ (22) Pooled probit } \\
\hline & & & & & Treated & Control & Std. mean & Var. ratio & Treated & Control & Std. mean & Var. ratio \\
\hline \# of Banking crises over past- 5 years $(t-5, t)$ & 0.316 & 0.147 & 0.405 & 1.767 & 0.211 & 0.211 & 0.000 & 1.026 & 0.238 & 0.156 & 0.205 & 1.413 \\
\hline \# of Currency crises over past- 5 years $(t-5, t)$ & 0.474 & 0.148 & 0.687 & 2.245 & 0.247 & 0.247 & 0.000 & 0.944 & 0.320 & 0.167 & 0.337 & 1.671 \\
\hline Intensity of conflicts $(\mathrm{t}-1)$ & 0.816 & 1.251 & -0.219 & 0.533 & 1.161 & 1.161 & 0.000 & 1.042 & 1.109 & 1.232 & -0.059 & 0.732 \\
\hline Log of Real GDP per capita (t-1) & 5.490 & 7.356 & -0.427 & 1.994 & 6.388 & 6.388 & 0.000 & 3.001 & 6.418 & 7.233 & -0.174 & 2.484 \\
\hline Log. of public debt to GDP (t-1) & 3.985 & 3.657 & 0.507 & 0.785 & 3.832 & 3.832 & 0.000 & 0.760 & 3.823 & 3.678 & 0.236 & 0.591 \\
\hline Log. of domestic credit to GDP (t-1) & 3.308 & 3.486 & -0.297 & 0.634 & 3.326 & 3.326 & 0.000 & 0.673 & 3.251 & 3.472 & -0.384 & 0.509 \\
\hline Log. of liquid liabilities to GDP (t-1) & 3.361 & 3.655 & -0.517 & 0.968 & 3.470 & 3.470 & 0.000 & 0.604 & 3.417 & 3.637 & -0.440 & 0.497 \\
\hline Net capital inflows to GDP (t-1) & 3.733 & 2.443 & 0.247 & 1.120 & 3.788 & 3.789 & 0.000 & 1.272 & 2.516 & 2.544 & -0.005 & 1.075 \\
\hline Log. of foreign reserves to GDP (t-1) & 1.269 & 2.276 & -1.147 & 1.294 & 1.747 & 1.747 & 0.000 & 0.508 & 1.675 & 2.211 & -0.642 & 0.893 \\
\hline Current account to GDP (t-1) & -3.434 & -2.426 & -0.192 & 1.250 & -3.585 & -3.585 & 0.000 & 1.479 & -2.305 & -2.512 & 0.040 & 1.207 \\
\hline Financial openness index (t-1) & 0.392 & 0.480 & -0.257 & 1.097 & 0.440 & 0.440 & 0.000 & 1.067 & 0.517 & 0.474 & 0.124 & 1.096 \\
\hline Log of trade openness to GDP (t-1) & 3.885 & 4.031 & -0.283 & 1.237 & 3.980 & 3.980 & 0.000 & 0.635 & 3.849 & 4.024 & -0.357 & 0.931 \\
\hline Terms of trade growth $(\mathrm{t}-1)$ & 0.009 & 0.005 & 0.069 & 2.131 & 0.016 & 0.016 & 0.000 & 0.516 & 0.013 & 0.006 & 0.136 & 1.023 \\
\hline Floating exchange rate regime (t-1) & 0.395 & 0.091 & 0.751 & 2.969 & 0.269 & 0.269 & 0.000 & 1.026 & 0.225 & 0.111 & 0.305 & 1.807 \\
\hline Government accountability index & 0.379 & 0.683 & -0.338 & 1.499 & 0.381 & 0.381 & 0.000 & 1.354 & 0.630 & 0.655 & -0.029 & 1.295 \\
\hline Corruption index & -0.593 & -0.589 & -0.016 & 1.170 & -0.632 & -0.632 & 0.000 & 1.041 & -0.637 & -0.591 & -0.187 & 0.903 \\
\hline Trading partners' growth (t-1) & 2.761 & 3.702 & -0.496 & 0.799 & 3.153 & 3.153 & 0.000 & 0.924 & 3.338 & 3.633 & -0.158 & 0.717 \\
\hline US interest rate on gov.'s securities (t-1) & 8.409 & 4.442 & 0.916 & 1.570 & 7.299 & 7.299 & 0.000 & 0.435 & 6.878 & 4.786 & 0.501 & 0.908 \\
\hline
\end{tabular}

Table C.4: Balance diagnostics between the treated and control groups, Banking crises

\begin{tabular}{|c|c|c|c|c|c|c|c|c|c|c|c|c|}
\hline \multirow[b]{4}{*}{ Variables } & \multicolumn{8}{|c|}{ Banking crises } & & & & \\
\hline & \multirow{2}{*}{\multicolumn{4}{|c|}{ (1) Non weighted }} & \multicolumn{8}{|c|}{ (2) Weighted } \\
\hline & & & & & \multicolumn{4}{|c|}{ (21) Covariate Balancing propensity score } & \multicolumn{4}{|c|}{ (22) Pooled probit } \\
\hline & Treated & Control & Std. mean & Var. ratio & Treated & Control & Std. mean & Var. ratio & Treated & 1 Control & Std. mean & Var. ratio \\
\hline \# of Debt crises over past- 5 years $(t-5, t)$ & 0.147 & 0.149 & -0.005 & 1.266 & 0.154 & 0.154 & 0.000 & 1.431 & 0.173 & 0.149 & 0.051 & 1.778 \\
\hline \# of Currency crises over past- 5 years $(t-5, t)$ & 0.206 & 0.163 & 0.106 & 1.114 & 0.161 & 0.161 & 0.000 & 0.943 & 0.210 & 0.166 & 0.109 & 1.118 \\
\hline Intensity of conflicts $(\mathrm{t}-1)$ & 1.353 & 1.222 & 0.053 & 1.471 & 1.184 & 1.184 & 0.000 & 1.593 & 1.142 & 1.230 & -0.036 & 1.379 \\
\hline Log of Real GDP per capita (t-1) & 6.890 & 7.277 & -0.099 & 1.258 & 7.238 & 7.238 & 0.000 & 1.708 & 7.286 & 7.259 & 0.007 & 1.268 \\
\hline Log. of public debt to GDP (t-1) & 3.551 & 3.680 & -0.161 & 1.835 & 3.582 & 3.582 & 0.000 & 1.087 & 3.668 & 3.673 & -0.007 & 1.434 \\
\hline Log. of domestic credit to GDP (t-1) & 3.617 & 3.470 & 0.235 & 0.818 & 3.546 & 3.546 & 0.000 & 0.515 & 3.554 & 3.477 & 0.131 & 0.598 \\
\hline Log. of liquid liabilities to GDP (t-1) & 3.438 & 3.650 & -0.374 & 0.933 & 3.592 & 3.592 & 0.000 & 0.469 & 3.583 & 3.639 & -0.112 & 0.516 \\
\hline Net capital inflows to GDP (t-1) & 3.389 & 2.467 & 0.198 & 0.646 & 2.583 & 2.584 & 0.000 & 0.638 & 2.402 & 2.514 & -0.023 & 0.798 \\
\hline Log. of foreign reserves to GDP (t-1) & 1.809 & 2.244 & -0.503 & 1.073 & 2.136 & 2.136 & 0.000 & 0.779 & 2.050 & 2.222 & -0.198 & 1.039 \\
\hline Current account to GDP ( $\mathrm{t}-1)$ & -3.308 & -2.438 & -0.191 & 0.640 & -2.473 & -2.474 & 0.000 & 0.625 & -2.259 & -2.485 & 0.048 & 0.759 \\
\hline Financial openness index $(\mathrm{t}-1)$ & 0.367 & 0.480 & -0.347 & 0.911 & 0.483 & 0.483 & 0.000 & 1.038 & 0.482 & 0.475 & 0.021 & 1.089 \\
\hline Log of trade openness to GDP ( $t-1)$ & 3.822 & 4.033 & -0.372 & 1.768 & 4.009 & 4.009 & 0.000 & 1.623 & 4.057 & 4.023 & 0.059 & 1.755 \\
\hline Terms of trade growth $(\mathrm{t}-1)$ & 0.013 & 0.005 & 0.181 & 0.539 & 0.010 & 0.010 & 0.000 & 0.517 & 0.009 & 0.005 & 0.073 & 0.461 \\
\hline Floating exchange rate regime $(\mathrm{t}-1)$ & 0.176 & 0.103 & 0.211 & 1.616 & 0.115 & 0.115 & 0.000 & 1.029 & 0.110 & 0.107 & 0.010 & 1.056 \\
\hline Government accountability index & 0.537 & 0.673 & -0.157 & 1.287 & 0.713 & 0.713 & 0.000 & 1.010 & 0.713 & 0.666 & 0.056 & 1.132 \\
\hline Corruption index & -0.581 & -0.589 & 0.035 & 0.914 & -0.553 & -0.553 & 0.000 & 1.161 & -0.524 & -0.588 & 0.235 & 1.327 \\
\hline Trading partners' growth (t-1) & 4.225 & 3.625 & 0.356 & 0.384 & 3.984 & 3.984 & 0.000 & 0.357 & 3.983 & 3.655 & 0.191 & 0.446 \\
\hline US interest rate on gov.'s securities (t-1) & 6.973 & 4.535 & 0.567 & 1.434 & 4.984 & 4.984 & 0.000 & 0.312 & 5.393 & 4.669 & 0.204 & 0.521 \\
\hline
\end{tabular}


Table C.5: Balance diagnostics between the treated and control groups, Currency crises

\begin{tabular}{|c|c|c|c|c|c|c|c|c|c|c|c|c|}
\hline \multicolumn{13}{|c|}{ Currency crises } \\
\hline \multirow[b]{3}{*}{ Variables } & \multicolumn{4}{|c|}{ (1) Non weighted } & \multicolumn{8}{|c|}{ (2) Weighted } \\
\hline & \multirow[b]{2}{*}{ Treated } & \multirow[b]{2}{*}{ Control } & \multirow[b]{2}{*}{ Std. mean } & \multirow[b]{2}{*}{ Var. ratio } & \multicolumn{4}{|c|}{ (21) Covariate Balancing propensity score } & \multicolumn{4}{|c|}{ (22) Pooled probit } \\
\hline & & & & & Treated & Control & Std. mean & Var. ratio & Treated & Control & Std. mean & Var. ratio \\
\hline \# of Debt crises over past -5 years $(t-5, t)$ & 0.500 & 0.131 & 0.735 & 2.773 & 0.220 & 0.220 & 0.000 & 1.231 & 0.212 & 0.148 & 0.152 & 1.399 \\
\hline$\#$ of Banking crises over past- 5 years $(t-5, t)$ & 0.472 & 0.139 & 0.767 & 2.134 & 0.327 & 0.327 & 0.000 & 1.027 & 0.264 & 0.162 & 0.248 & 1.468 \\
\hline Intensity of conflicts $(\mathrm{t}-1)$ & 0.944 & 1.243 & -0.149 & 0.554 & 0.994 & 0.994 & 0.000 & 0.653 & 0.509 & 1.219 & -0.394 & 0.297 \\
\hline Log of Real GDP per capita (t-1) & 5.308 & 7.360 & -0.490 & 1.707 & 6.914 & 6.915 & 0.000 & 1.319 & 7.130 & 7.262 & -0.035 & 1.174 \\
\hline Log. of public debt to GDP (t-1) & 3.749 & 3.670 & 0.114 & 1.039 & 3.764 & 3.764 & 0.000 & 1.276 & 3.983 & 3.678 & 0.427 & 1.167 \\
\hline Log. of domestic credit to GDP (t-1) & 3.374 & 3.482 & -0.167 & 0.913 & 3.474 & 3.474 & 0.000 & 1.125 & 3.603 & 3.477 & 0.197 & 0.872 \\
\hline Log. of liquid liabilities to GDP $(\mathrm{t}-1)$ & 3.432 & 3.651 & -0.375 & 1.078 & 3.622 & 3.622 & 0.000 & 0.868 & 3.790 & 3.640 & 0.262 & 0.981 \\
\hline Net capital inflows to GDP (t-1) & 3.975 & 2.434 & 0.336 & 0.591 & 3.604 & 3.603 & 0.000 & 0.745 & 3.617 & 2.554 & 0.220 & 0.788 \\
\hline Log. of foreign reserves to GDP (t-1) & 1.252 & 2.274 & -1.314 & 0.750 & 1.688 & 1.688 & 0.000 & 0.302 & 1.816 & 2.205 & -0.467 & 0.749 \\
\hline Current account to GDP (t-1) & -3.531 & -2.424 & -0.243 & 0.631 & -3.158 & -3.157 & 0.000 & 0.736 & -3.259 & -2.499 & -0.163 & 0.756 \\
\hline Financial openness index (t-1) & 0.327 & 0.483 & -0.504 & 0.702 & 0.401 & 0.401 & 0.000 & 1.061 & 0.496 & 0.473 & 0.064 & 1.362 \\
\hline Log of trade openness to GDP (t-1) & 3.665 & 4.042 & -0.740 & 1.230 & 3.840 & 3.840 & 0.000 & 0.591 & 3.912 & 4.018 & -0.223 & 0.797 \\
\hline Terms of trade growth $(\mathrm{t}-1)$ & 0.013 & 0.005 & 0.154 & 1.399 & 0.009 & 0.009 & 0.000 & 0.829 & 0.005 & 0.006 & -0.005 & 0.669 \\
\hline Floating exchange rate regime (t-1) & 0.389 & 0.092 & 0.733 & 2.923 & 0.213 & 0.213 & 0.000 & 1.027 & 0.140 & 0.109 & 0.092 & 1.270 \\
\hline Government accountability index & 0.455 & 0.678 & -0.256 & 1.304 & 0.326 & 0.326 & 0.000 & 0.793 & 0.234 & 0.648 & -0.486 & 1.077 \\
\hline Corruption index & -0.579 & -0.589 & 0.040 & 1.150 & -0.598 & -0.598 & 0.000 & 1.550 & -0.652 & -0.588 & -0.230 & 1.480 \\
\hline Trading partners' growth $(\mathrm{t}-1)$ & 3.501 & 3.661 & -0.090 & 0.532 & 3.436 & 3.435 & 0.000 & 0.506 & 3.263 & 3.638 & -0.216 & 0.483 \\
\hline US interest rate on gov.'s securities ( $\mathrm{t}-1)$ & 7.388 & 4.507 & 0.669 & 1.466 & 6.088 & 6.088 & 0.000 & 1.265 & 5.335 & 4.718 & 0.139 & 1.432 \\
\hline
\end{tabular}

\section{B. Overlap checks}

Figure C.2: Kernel density of the distribution of the propensity scores for the treated and control groups
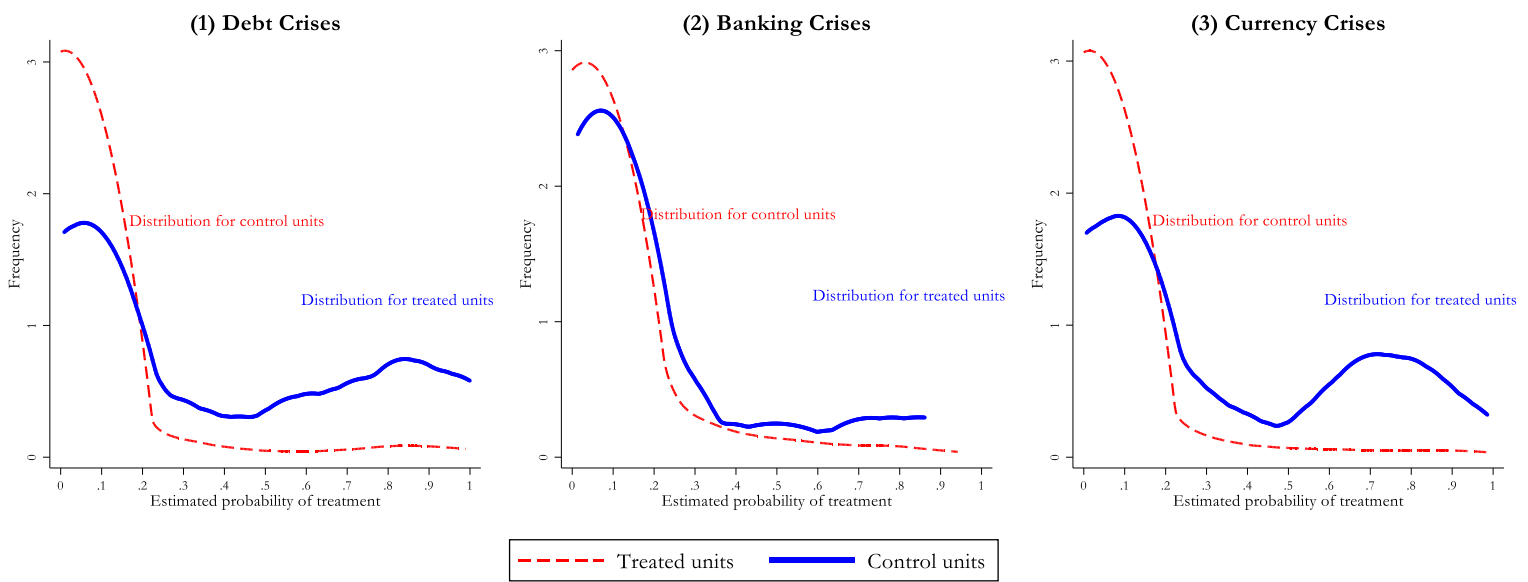

Notes: The predicted propensity scores in (1), (2), and (3) a re obtained a fter a pplying the CBPS estimator. The dependent variable equals to 1 at the start of financial crises, 0 in country-years observations without crises (unfolding). We use the la rgest set of controlvariables described in the data section and included with lags to reduce potential issues of endogeneity. These figures display a high probability of financial crises for the treated groups (especially for debt and currency crises) and a low probability for their counterparts. More importantly, they show a significant overlap between the treated and control groups. Since some observations receive a la rge weight, we set the maximum weight to 10 for the ATE-AIPWestimates. 


\section{APPENDIX IV. SUPPLEMENTARY GRAPHS AND TABLES}

\section{A. Graphs}

\section{A.1. Benchmark and robustness results}

Figure D.3: Robustness, cumulative trade losses over five years after combined financial crises

Panel I: Exports (percent of pre-crisis GDP)
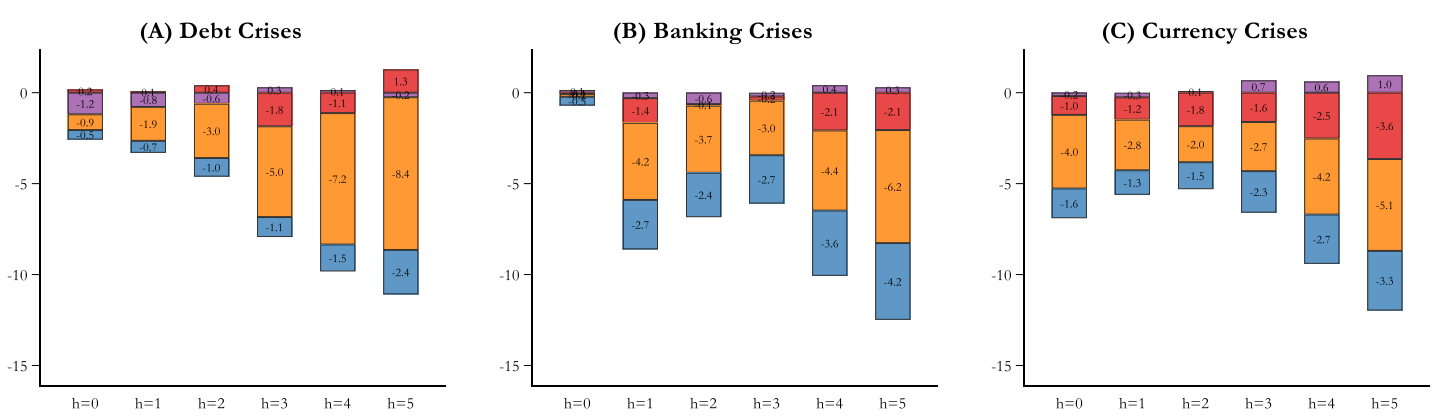

Panel II: Imports (percent of pre-crisis GDP)

(A) Debt Crises

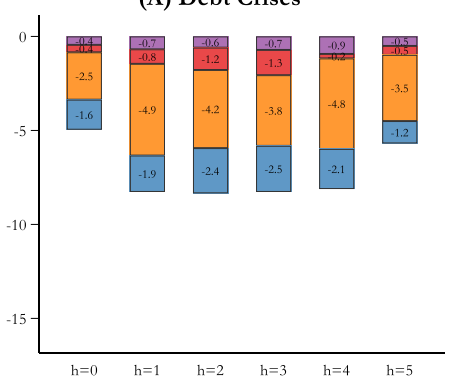

Agriculture
(B) Banking Crises

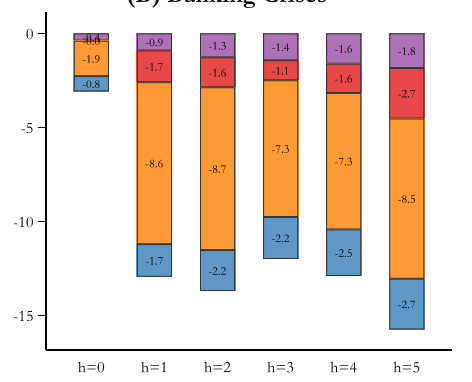

Mining

Manufacturing

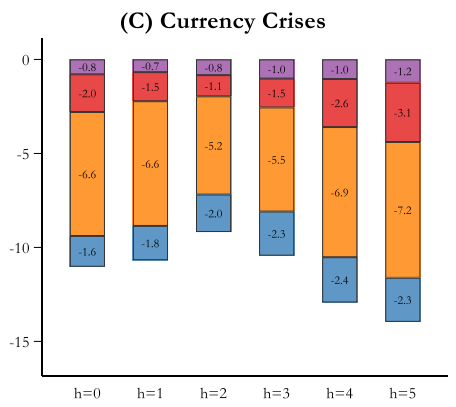

Services

Notes: Robust standard errors clustered at the country-level in parentheses. AIPW estimates. The dependent variables are 100 times the cumulative change of agricultural, mining, manufacturing, and services exports and imports rela tive to the year prior to the onset of the crisis for years $1-5$ a fter the onset of the crisis, sca led precrisis GDP. Accumulated losses over five years. Maximum weights truncated at 10. 
Figure D.4: Robustness, cumulative trade losses over five years after individual financial crises

Panel I: Exports (percent of pre-crisis GDP)

(A) Debt Crises

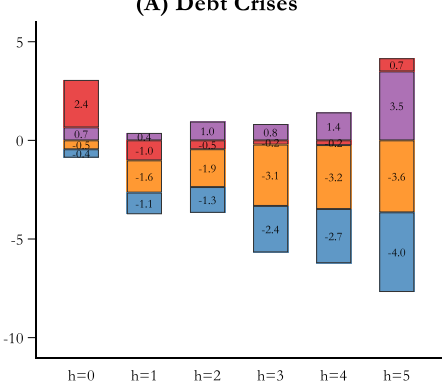

(B) Banking Crises

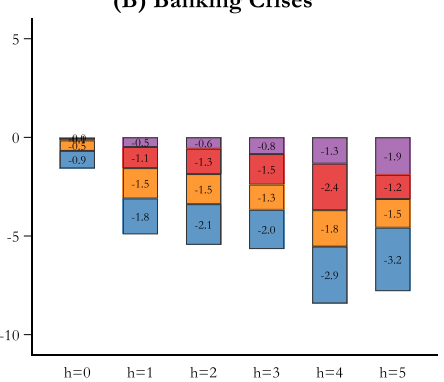

(C) Currency Crises

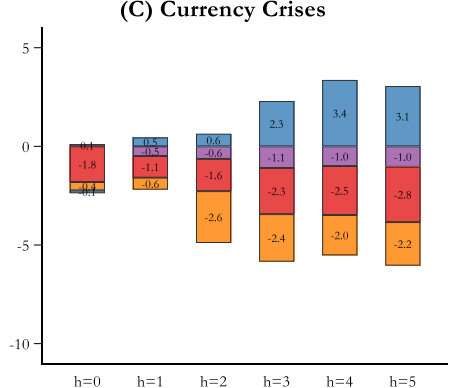

Panel II: Imports (percent of pre-crisis GDP)

(A) Debt Crises

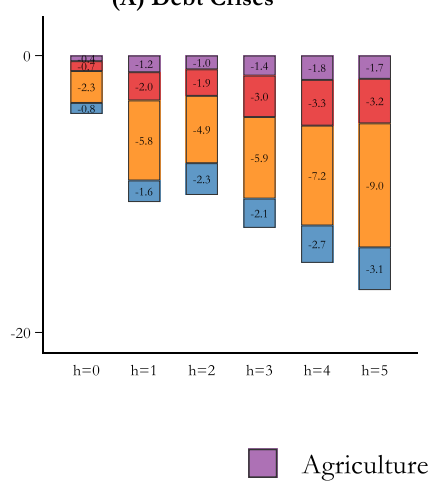

(B) Banking Crises

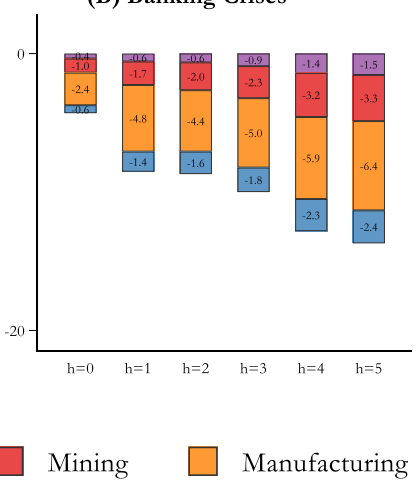

(C) Currency Crises

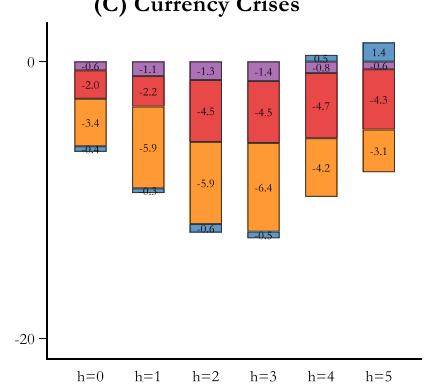

Services

Notes: Robust standard errors clustered at the country-level in parentheses. AIPW estimates. The dependent variables are 100 times the cumulative change of agricultural, mining, manufacturing, and services exports and imports rela tive to the year prior to the onset of the crisis for years $1-5$ a fter the onset of the crisis, sca led precrisis GDP. Accumulated losses over fiveyears. Maximum weights truncated at 10. 
Figure D.5: Robustness, Drop the period 2008 onwards, cumulative trade losses over five years after financial

Panel I: Exports (percent of pre-crisis GDP)
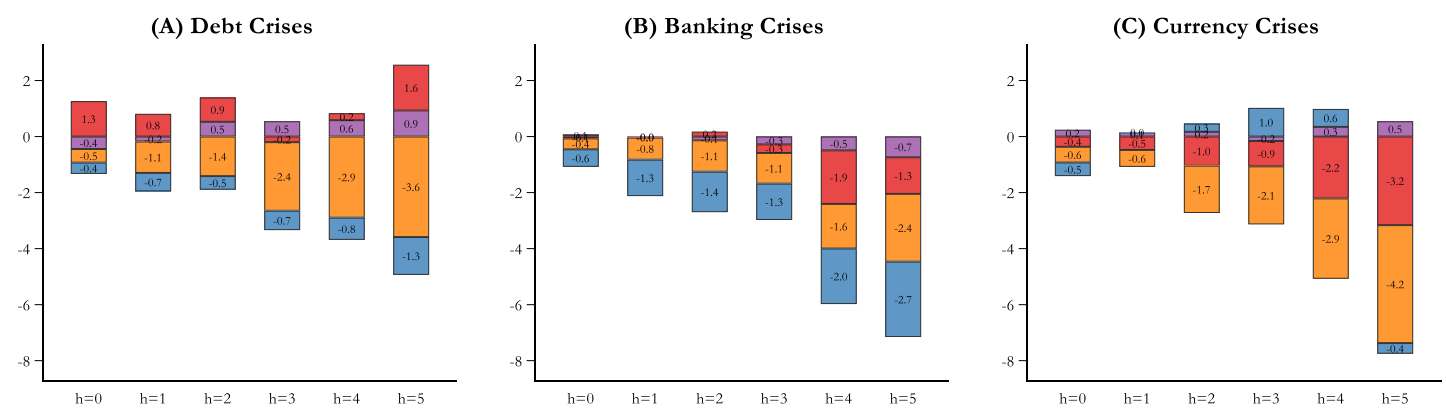

Panel II: Imports (percent of pre-crisis GDP)

(A) Debt Crises

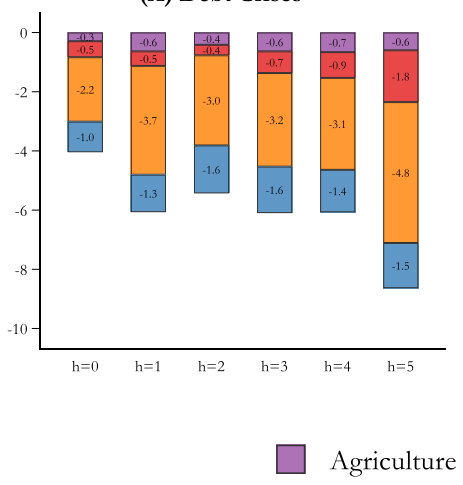

(B) Banking Crises

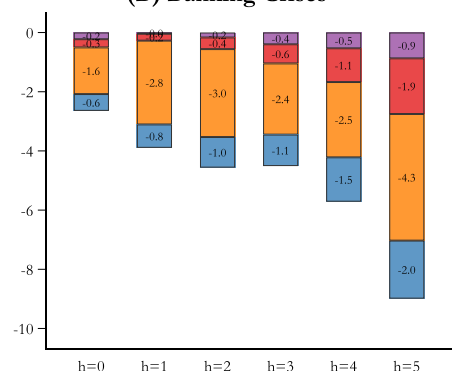

Mining
Manufacturing
(C) Currency Crises

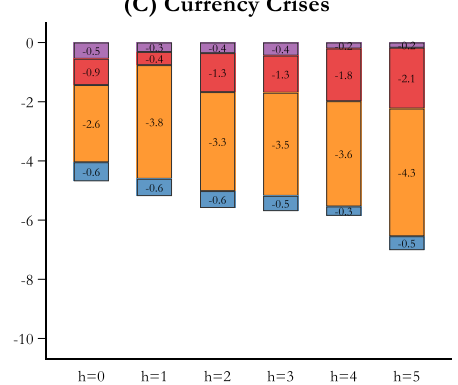

Services

Notes: Robust standard errors clustered at the country-level in parentheses. AIPW estimates. The dependent variables are 100 times the cumulative change of agricultural, mining, manufacturing, and services exports and imports rela tive to the year prior to the onset of the crisis for years $1-5$ a fter the onset of the crisis, sca led precrisis GDP. Accumulated losses over five years. Maximum weights truncated at 10. 
Figure D.6: Robustness, Maximum weight set to 20, cumulative trade losses over five years after financial

Panel I: Exports (percent of pre-crisis GDP)

(A) Debt Crises

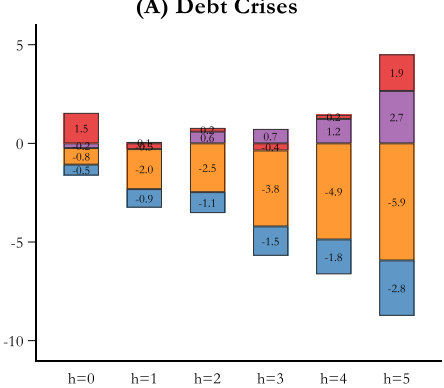

(B) Banking Crises

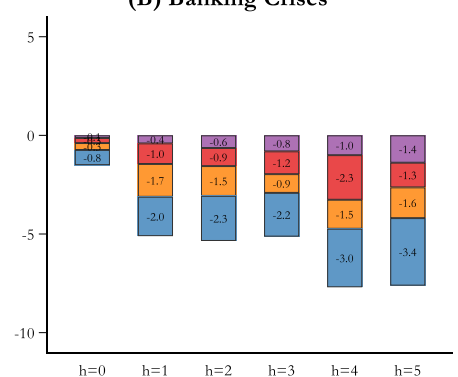

(C) Currency Crises

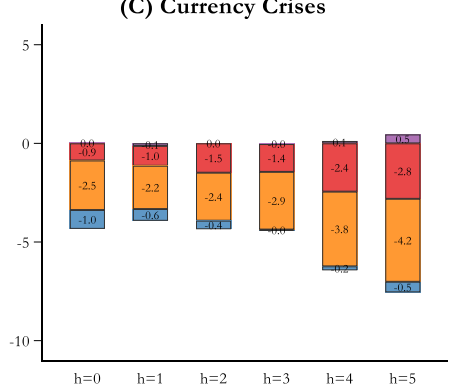

Panel II: Imports (percent of pre-crisis GDP)

(A) Debt Crises

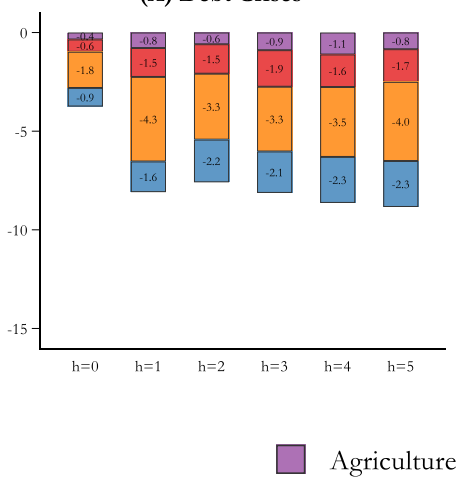

(B) Banking Crises

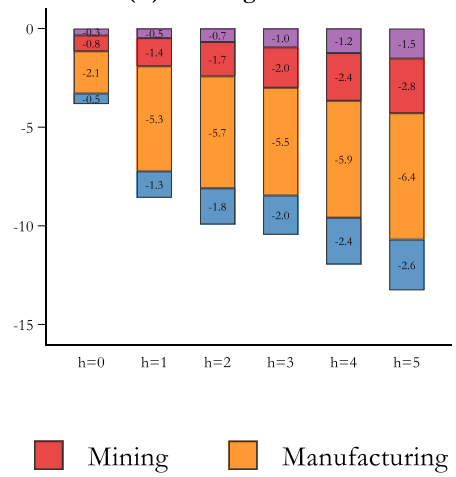

(C) Currency Crises

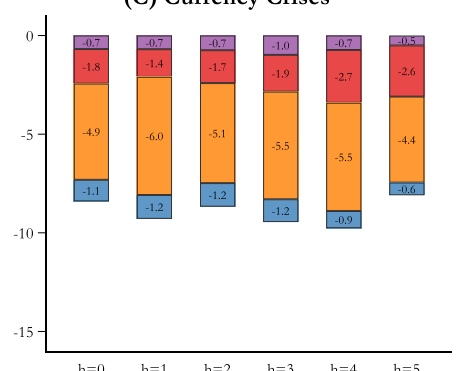

Services

Notes: Robust standard errors clustered at the country-level in parentheses. AIPW estimates. The dependent variables are 100 times the cumulative change of agricultural, mining, manufacturing, and services exports and imports rela tive to the year prior to the onset of the crisis for years $1-5$ a fter the onset of the crisis, sca led precrisis GDP. Accumulated losses over five years. Maximum weights truncated at 20. 
Figure D.7: Robustness, Maximum weight set to 5, cumulative trade losses over five years after financial

Panel I: Exports (percent of pre-crisis GDP)

(A) Debt Crises

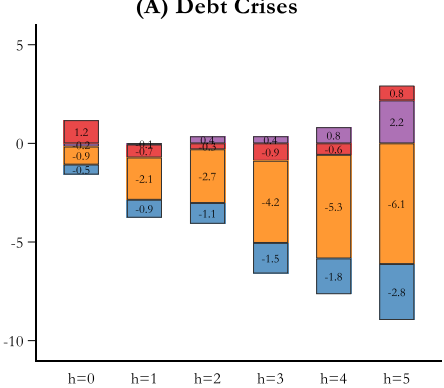

(B) Banking Crises

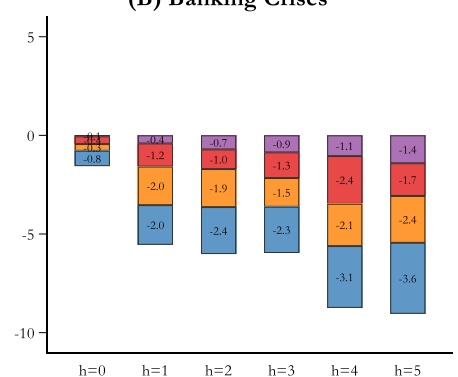

(C) Currency Crises

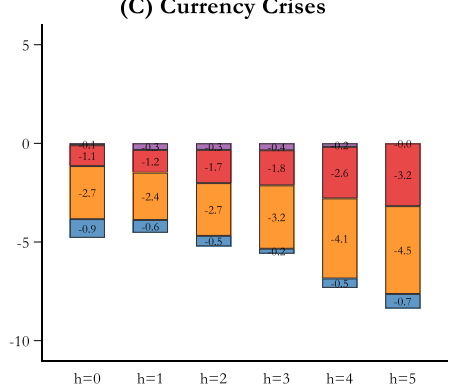

Panel II: Imports (percent of pre-crisis GDP)

(A) Debt Crises

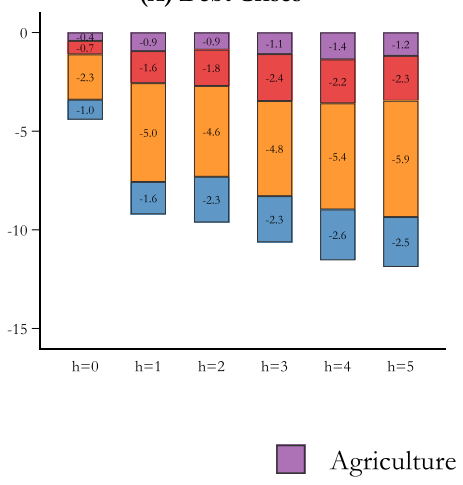

(B) Banking Crises

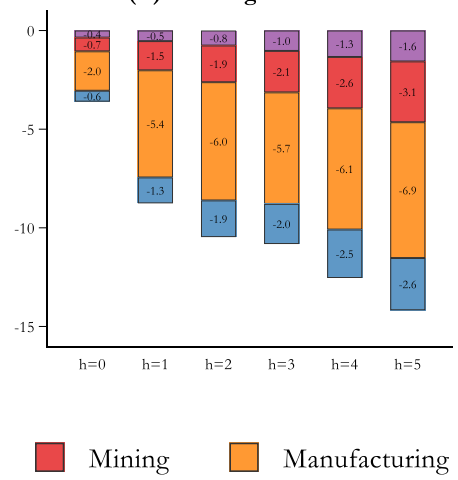

(C) Currency Crises

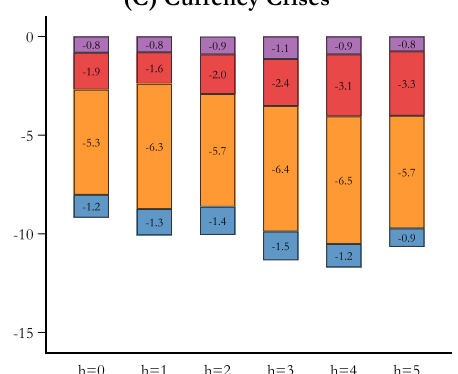

Services

Notes: Robust standard errors clustered at the country-level in parentheses. AIPW estimates. The dependent variables are 100 times the cumulative change of agricultural, mining, manufacturing, and services exports and imports rela tive to the year prior to the onset of the crisis for years $1-5$ after the onset of the crisis, sca led precrisis GDP. Accumulated losses over fiveyears. Maximum weights truncated at 5. 
Figure D.8: Robustness, Alternative sources and de finitions of crises, cumulative trade losses over five years

Panel I: Exports (percent of pre-crisis GDP)

(A) Debt Crises

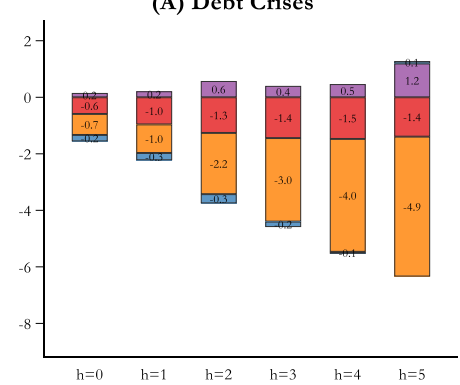

(B) Banking Crises

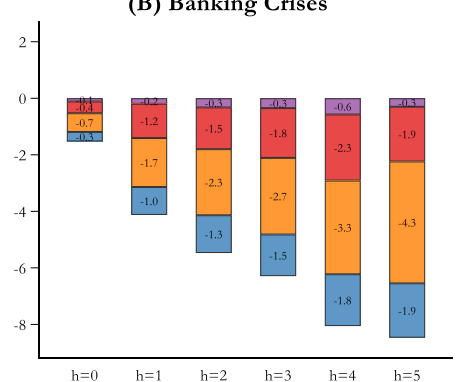

(C) Currency Crises

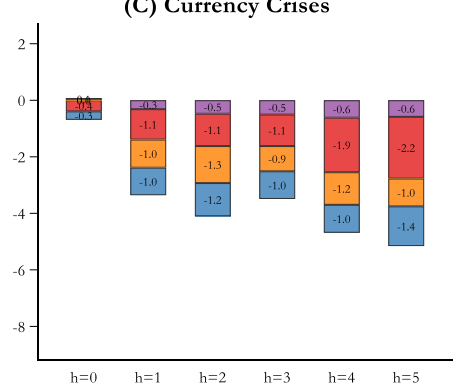

Panel II: Imports (percent of pre-crisis GDP)

(A) Debt Crises

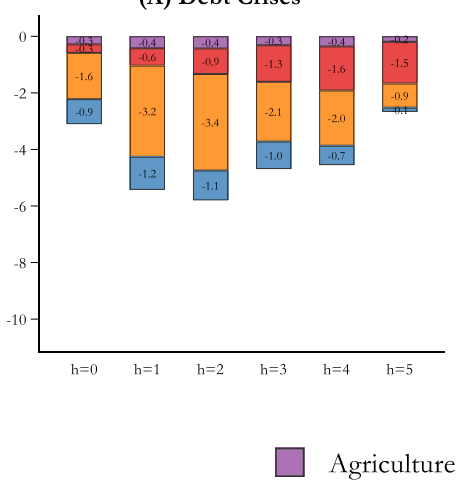

(B) Banking Crises

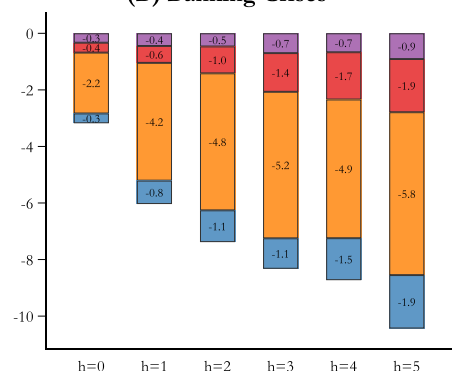

Mining
Manufacturing
(C) Currency Crises

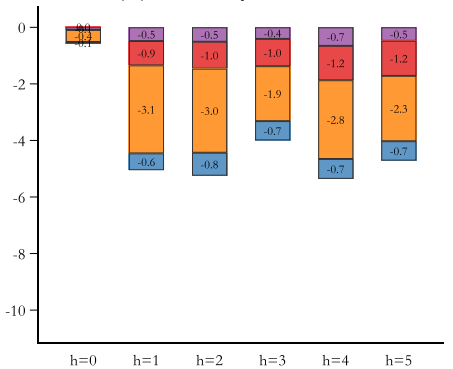

Services

Notes: Robust standard errors clustered at the country-level in parentheses. AIPW estimates. The dependent variables are 100 times the cumulative change of agricultural, mining, manufacturing, and services exports and imports rela tive to the year prior to the onset of the crisis for years $1-5$ after the onset of the crisis, sca led precrisis GDP. Accumulated losses over five years. Maximum weights truncated at 10. 
Figure D.9: Robustness, Inverse Probability Weighted (IPW) estimator, cumulative trade losses over five

Panel I: Exports (percent of pre-crisis GDP)

(A) Debt Crises

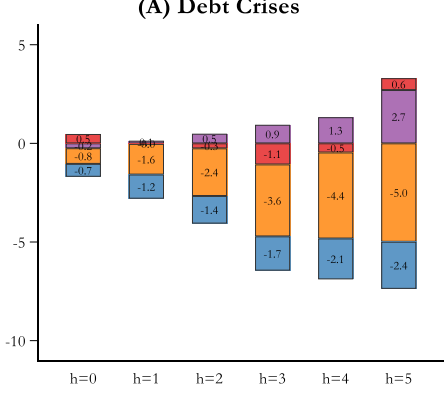

(B) Banking Crises

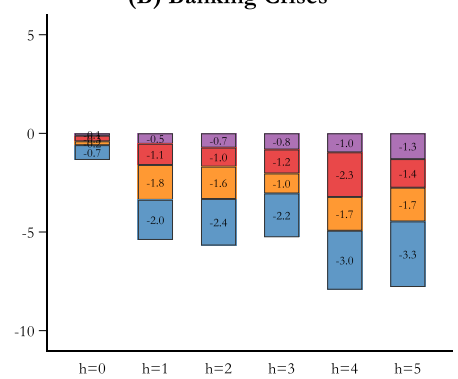

(C) Currency Crises

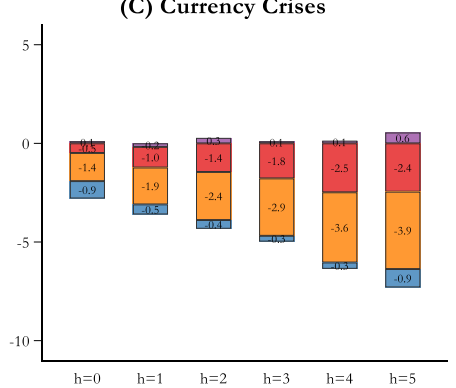

Panel II: Imports (percent of pre-crisis GDP)

(A) Debt Crises

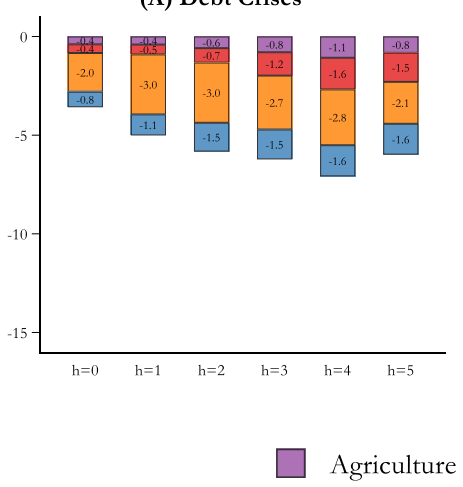

(B) Banking Crises

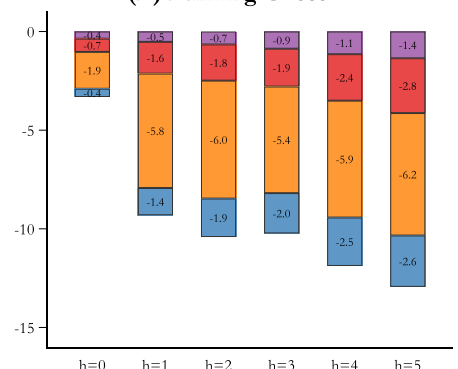

Mining
Manufacturing
(C) Currency Crises

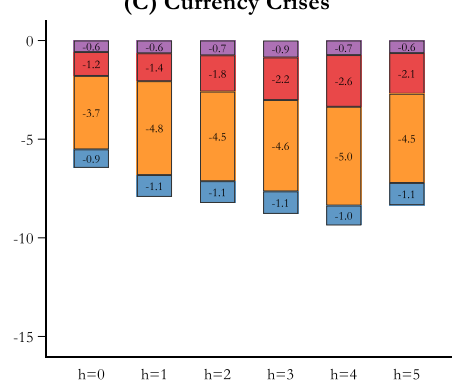

Services

Notes: Robust standard errors clustered at the country-level in parentheses. AIPW estimates. The dependent variables are 100 times the cumulative change of agricultural, mining, manufacturing, and services exports and imports rela tive to the year prior to the onset of the crisis for years $1-5$ after the onset of the crisis, sca led precrisis GDP. Accumulated losses over five years. Maximum weights truncated at 10. 


\section{A.2. Channels}

Figure D.10: Channels, cumulative trade costs over five years after financial crises with and without a higher share of manufacturing exports

\section{Panel I: Higher Manufacturing exports at T-1}

(A): Exports (percent of pre-crisis GDP)
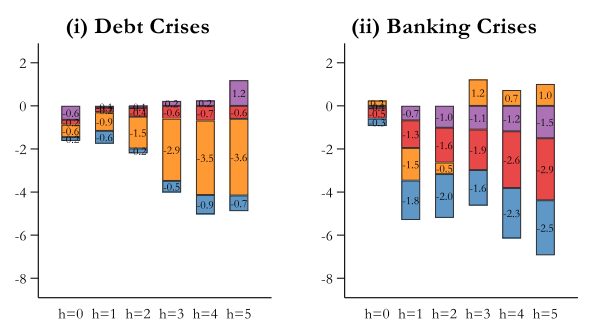

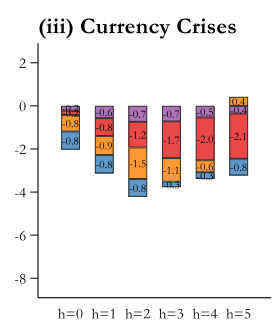

(B): Imports (percent of pre-crisis GDP)
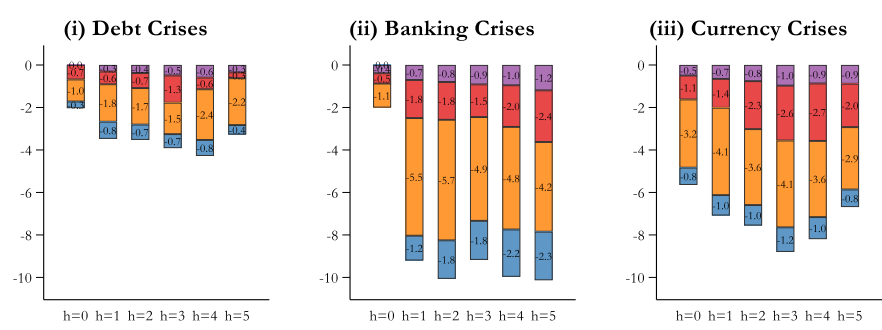

Panel II: Lower Manufacturing exports at T-1

(A): Exports (percent of pre-crisis GDP)

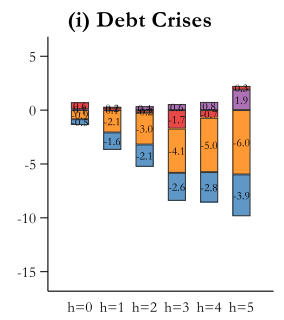

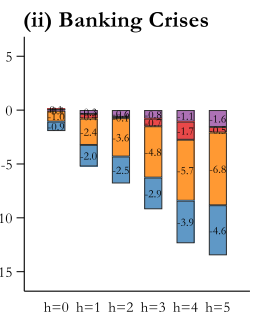

Agriculture

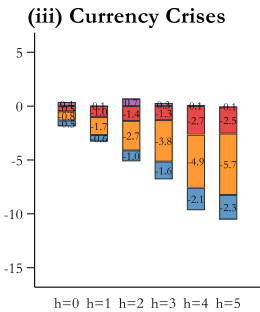

$h=0 h=1 h=2 h=3 h=4 h=5$

(B): Imports (percent of pre-crisis GDP)

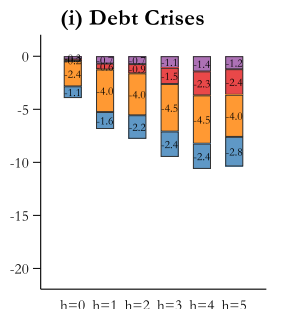

$h=0 \quad h=1 \quad h=2 \quad h=3 \quad h=4 h=5$

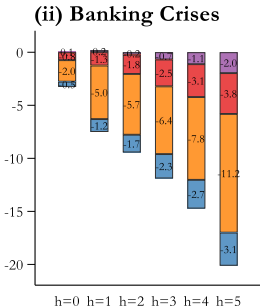

$h=0 h=1 h=2 h=3 h=4 h=5$

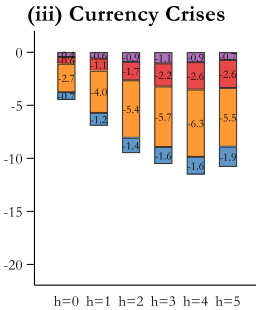

Manufacturing

Services

Notes: Robust standard errors clustered at the country-level in parentheses. AIPW estimates. The dependent variables are 100 times the cumulative change of a gricultural, mining, manufacturing, and services exports and imports relative to the year prior to the onset of the crisis for years $1-5$ after the onset of the crisis, scaled pre-crisis GDP. Accumulated losses over five years. Maximum weights truncated at 10 
Figure D.11: Channels, cumulative trade costs over five years after financial crises with and without a higher export diversi fication

\section{Panel I: Higher Export diversification at T-1}

(A): Exports (percent of pre-crisis GDP)

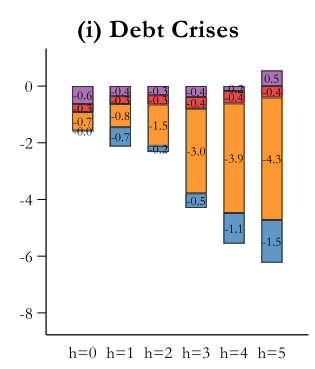

(ii) Banking Crises

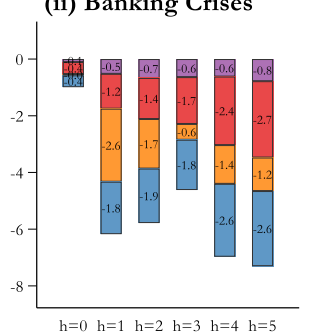

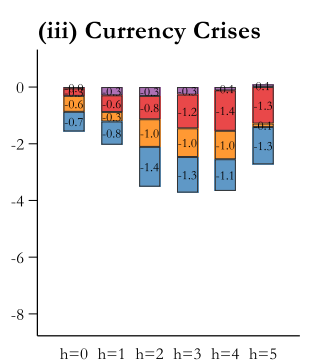

(B): Imports (percent of pre-crisis GDP)
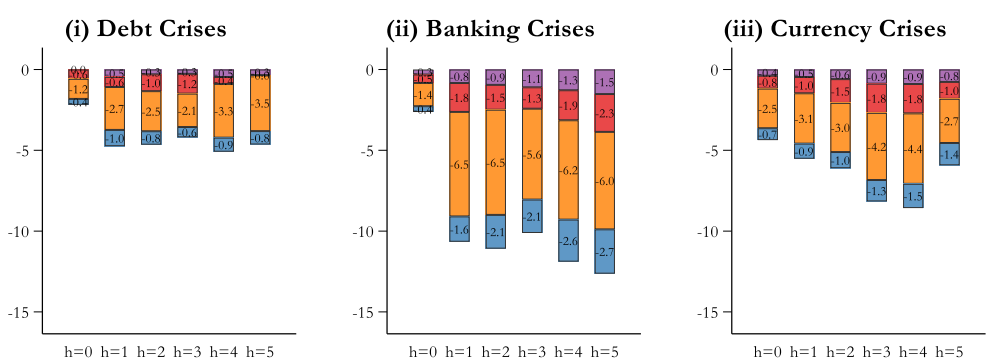

Panel II: Lower Export diversification at T-1

(A): Exports (percent of pre-crisis GDP)

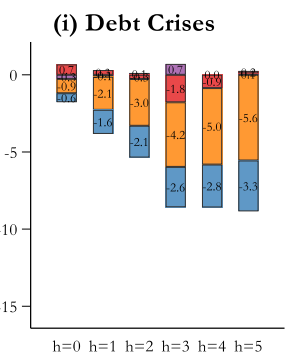

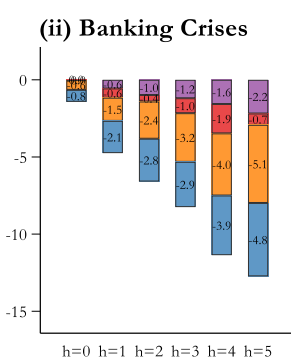

Agriculture

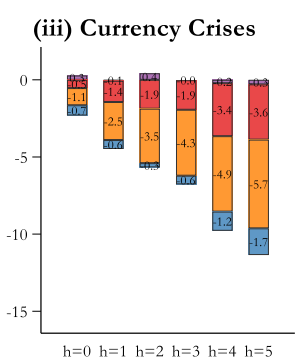

Mining

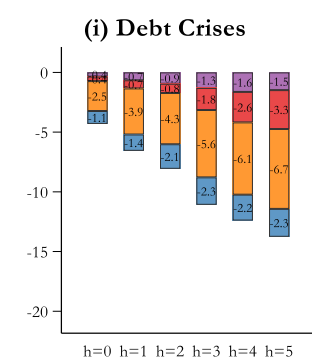

(B): Imports (percent of pre-crisis GDP)

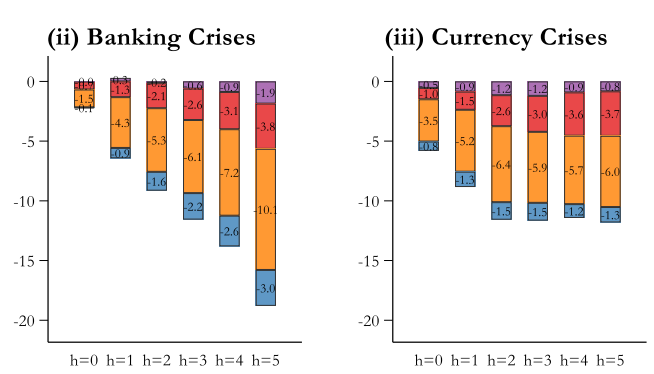

Manufacturing

Notes: Robust standard errors clustered at the country-level in parentheses. AIPW estimates. The dependent variables are 100 times the cumulative change of a gricultural, mining, manufacturing, and services exports and imports relative to the year prior to the onset of the crisis f or years $1-5$ after the onset of the crisis, scaled pre-crisis GDP. Accumulated losses over five years. Maximum weights truncated at 10 
Figure D.12: Channels, cumulative trade costs over five years after financial crises with and without a higher trading partne rs diversification

\section{Panel I: Higher Trading partners diversification at T-1}

(A): Exports (percent of pre-crisis GDP)
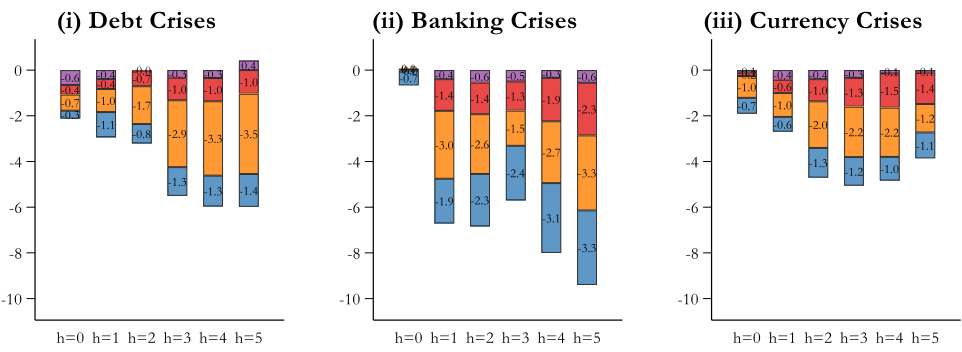

(B): Imports (percent of pre-crisis GDP)

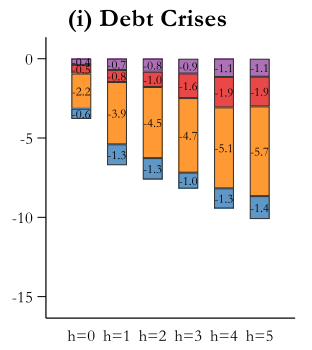

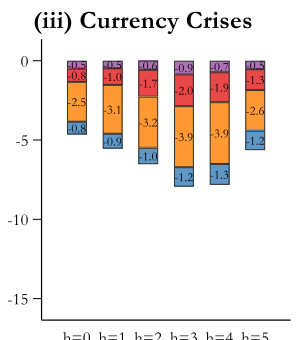

Panel II: Lower Trading partners diversification at T-1

(A): Exports (percent of pre-crisis GDP)

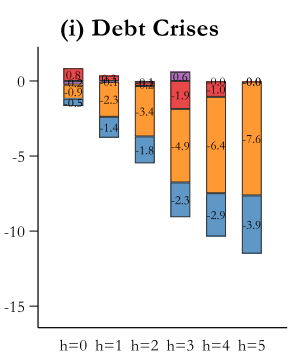

(ii) Banking Crises

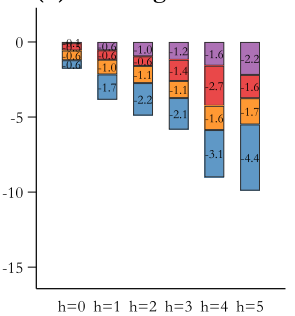

Agriculture (iii) Currency Crises

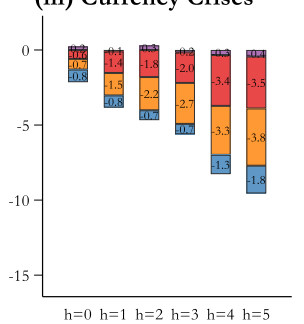

Mining
(B): Imports (percent of pre-crisis GDP)
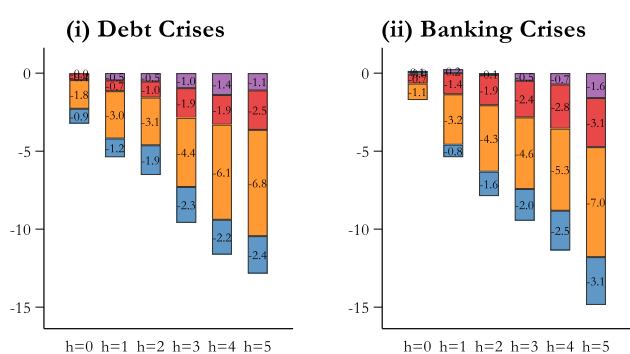

(iii) Currency Crises

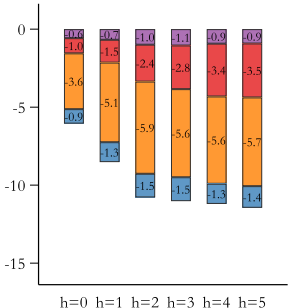

Notes: Robust standard errors clustered at the country-level in parentheses. AIPW estimates. The dependent variables a re 100 times the cumulative change of a gricultural, mining, manufacturing, and services exports and imports relative to the year prior to the onset of the crisis for years $1-5$ after the onset of the crisis, scaled pre-crisis GDP. Accumulated losses over five years. Maximum weights truncated at 10 
Figure D.13: Channels, cumulative trade costs over five years after financial crises with and without a higher trading partners' growth

Panel I: Higher Trading partners' growth over $\mathbf{T}+0$ to $\mathbf{T}+5$

(A): Exports (percent of pre-crisis GDP)

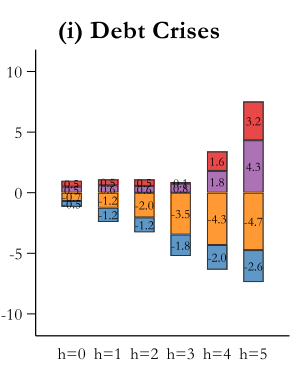

(ii) Banking Crises

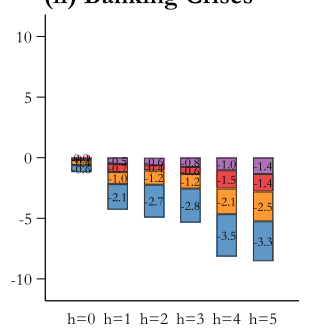

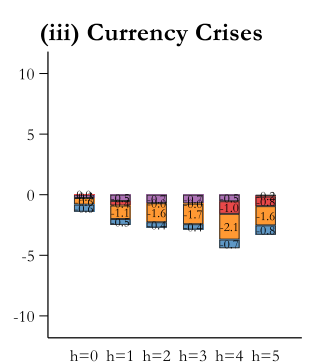

(B): Imports (percent of pre-crisis GDP)

Panel II: Lower Trading partners' growth over $\mathbf{T}+0$ to $\mathrm{T}+5$

(A): Exports (percent of pre-crisis GDP)

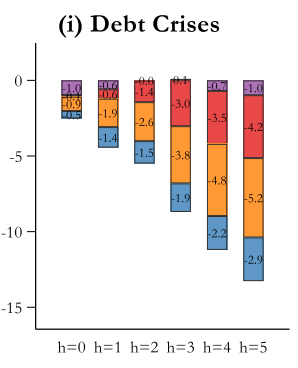

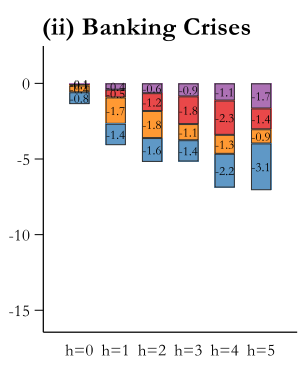

Agriculture

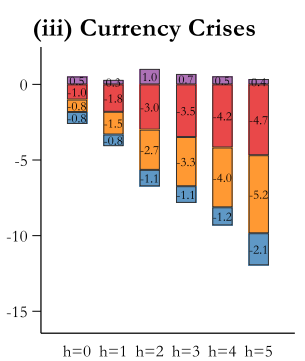

Mining

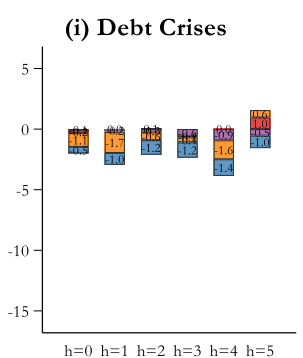

(B): Imports (percent of pre-crisis GDP)
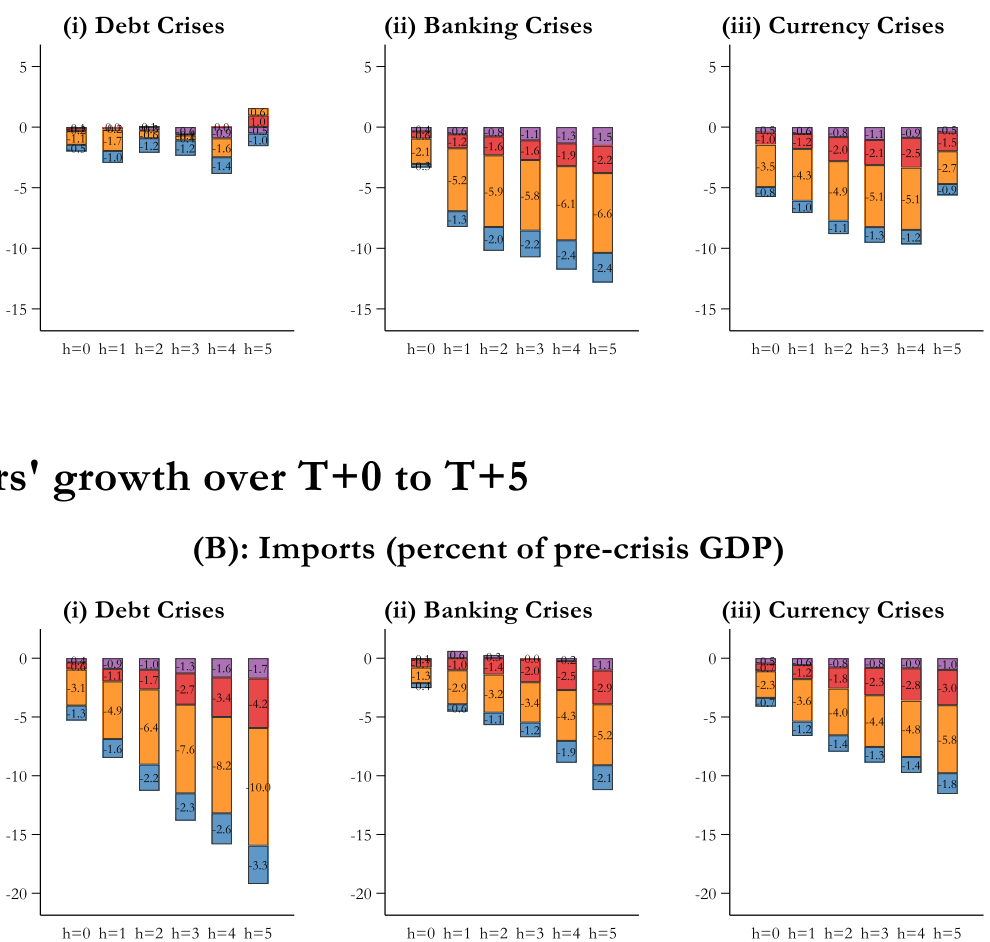

Notes: Robust standard errors clustered at the country-level in pa rentheses. AIPW estimates. The dependent variables a re 100 times the cumulative change of a gricultural, mining, manufacturing, and services exports and imp orts relative to the year prior to the onset of the crisis for years $1-5$ after the onset of the crisis, scaled pre-crisis GDP. Accumulated losses over five years. Maximum weights truncated at 10 
Figure D.14: Channels, cumulative trade costs over five years after financial crises with and without a higher financial development

\section{Panel I: Higher Financial Development over $\mathbf{T}+0$ to $\mathbf{T}+5$}

(A): Exports (percent of pre-crisis GDP)
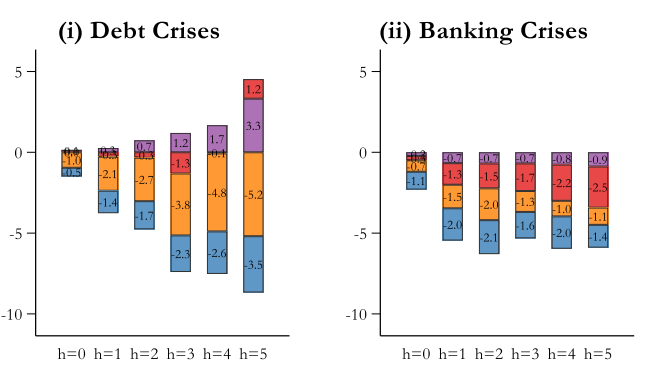
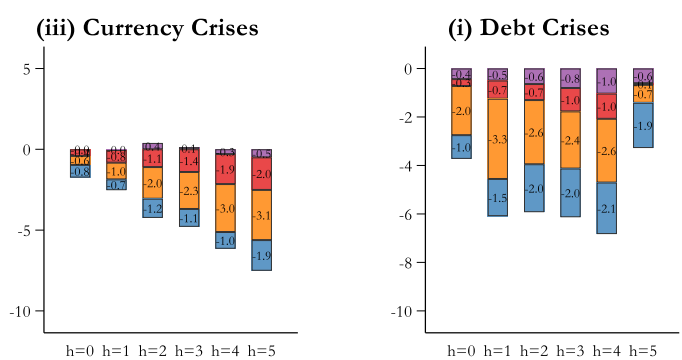

(B): Imports (percent of pre-crisis GDP)

$h=0 \quad h=1 \quad h=2 \quad h=3 \quad h=4 \quad h=5$
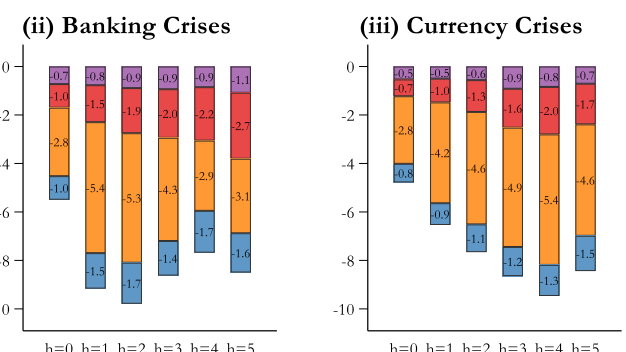

Panel II: Lower Financial Development over $\mathbf{T}+0$ to $\mathrm{T}+5$

(A): Exports (percent of pre-crisis GDP)

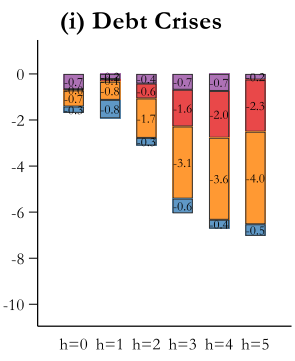

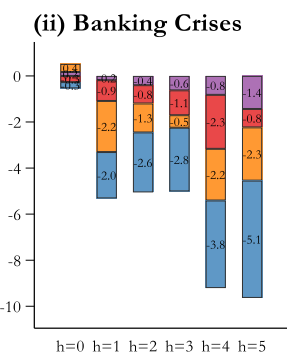

Agriculture

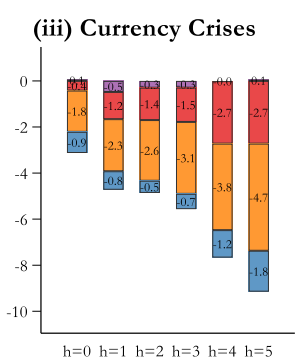

Mining
(B): Imports (percent of pre-crisis GDP)
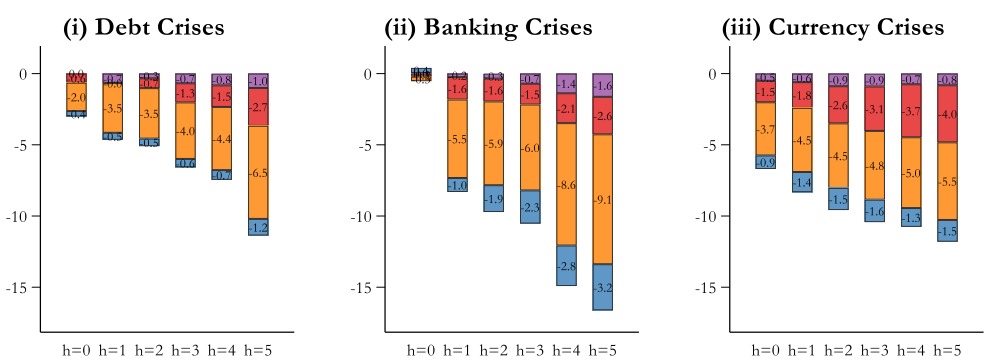

Manufacturing

Services

Notes: Robust standard errors clustered at the country-level in pa rentheses. AIPW estimates. The dependent variables a re 100 times the cumulative change of a gricultural, mining, manufacturing, and services exports and imports relative to theyear prior to the onset of the crisis for years $1-5$ after the onset of the crisis, scaled pre-crisis GDP. Accumulated losses over five years. Maximum weights truncated at 10 
Figure D.15: Channels, cumulative trade costs over five years after financial crises with and without higher gross capital inflows

\section{Panel I: Higher Gross Capital inflows over $\mathbf{T}+0$ to $\mathbf{T}+5$}

(A): Exports (percent of pre-crisis GDP)

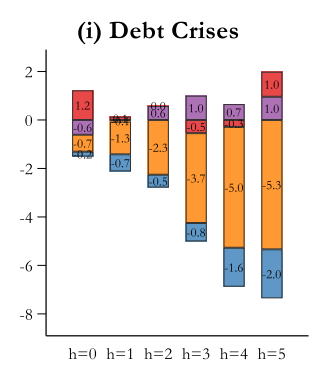

(ii) Banking Crises

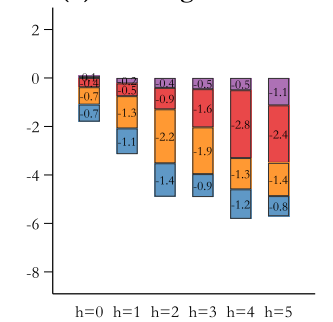

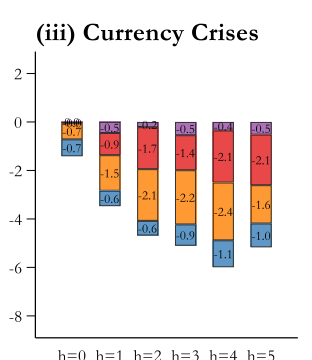

(B): Imports (percent of pre-crisis GDP)

Panel II: Lower Gross Capital inflows over $\mathrm{T}+0$ to $\mathrm{T}+5$

(A): Exports (percent of pre-crisis GDP)

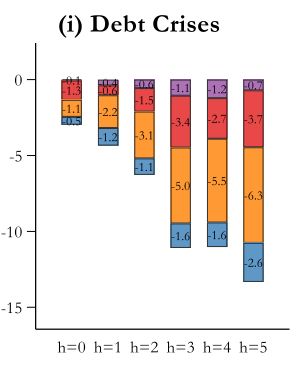

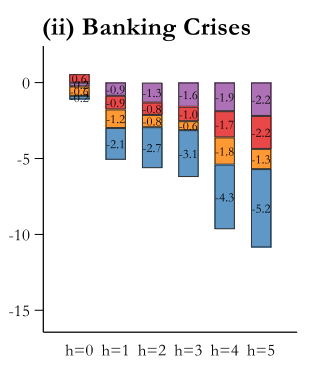

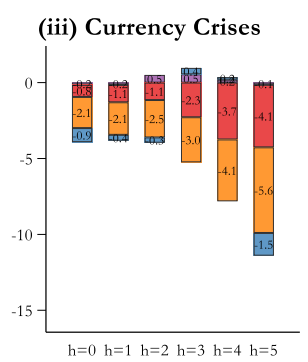

Agriculture
Mining
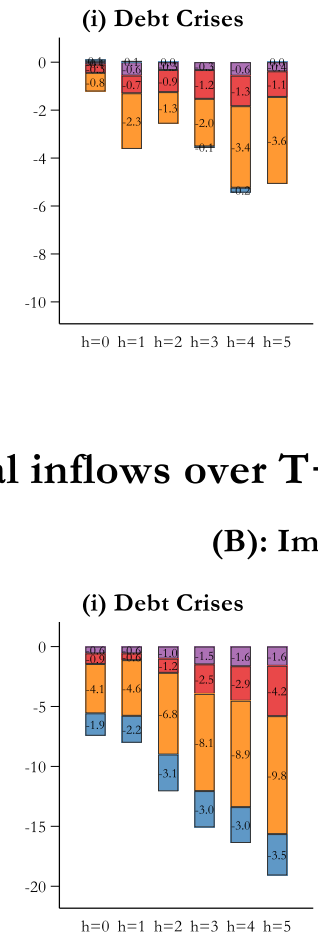

(B): Imports (percent of pre-crisis GDP)
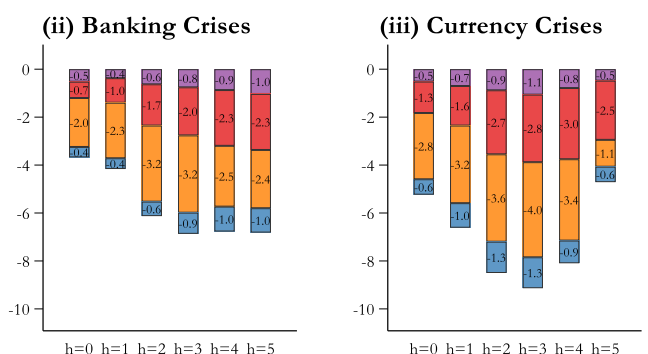

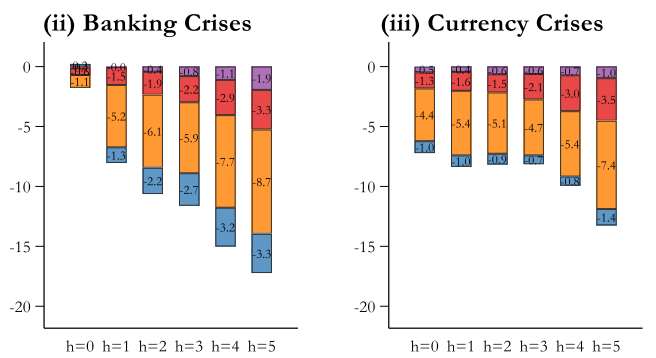

Manufacturing

Services

Notes: Robust standard errors clustered at the country-level in parentheses. AIPW estimates. The dependent variables are 100 times the cumulative change of a gricultural, mining, manufacturing, and services exports and imports relative to the year prior to the onset of the crisis for years $1-5$ after the onset of the crisis, scaled pre-crisis GDP. Accumulated losses over five years. Maximum weights truncated at 10 
Figure D.16: Channels, cumulative trade costs over five years after financial crises with and without a higher investors' cre dit rating risks

Panel I: Higher Investors' credit ratings risks over 'T+0 to 'T+5

(A): Exports (percent of pre-crisis GDP)
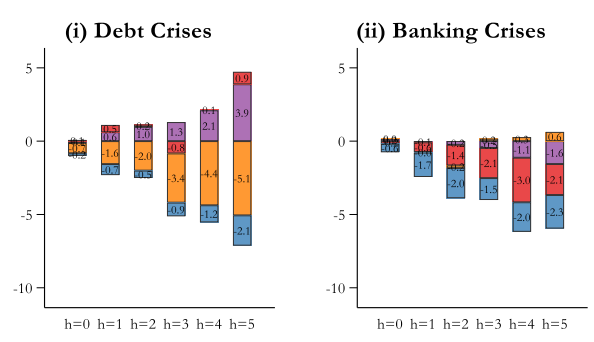

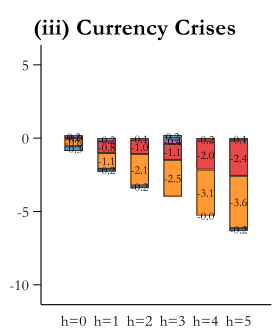

(B): Imports (percent of pre-crisis GDP)
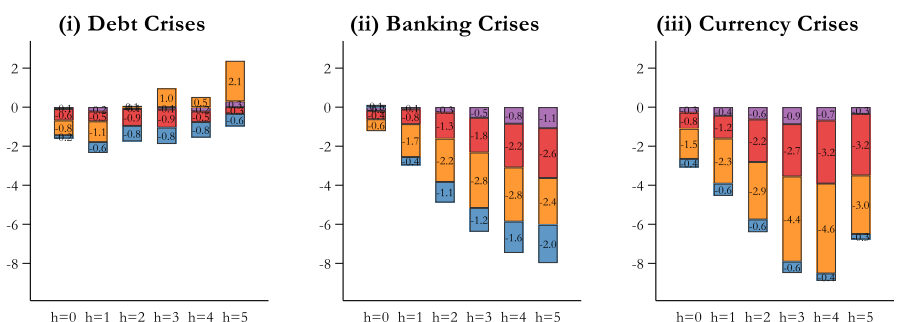

Panel II: Higher Investors' credit ratings risks over $\mathbf{T}+0$ to $\mathbf{T}+5$

(A): Exports (percent of pre-crisis GDP)

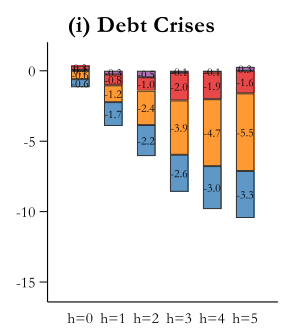

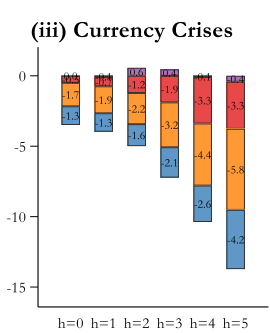

Mining
(B): Imports (percent of pre-crisis GDP)
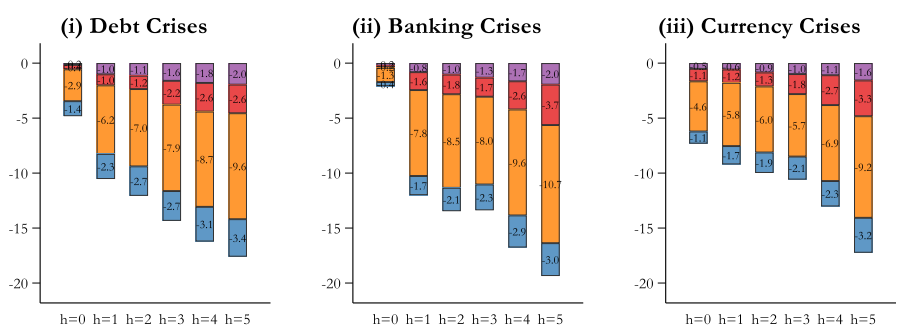

Agriculture

Manufacturing

Services

Notes: Robust standard errors clustered at the country-level in pa rentheses. AIPW estimates. The dependent variables are 100 times the cumulative change of a gricultural, mining, manufacturing, and services exports and imports relative to theyear prior to the onset of the crisis for years $1-5$ after the onset of the crisis, sca led pre-crisis GDP. Accumulated losses over five years. Maximum weights truncated at 10 


\section{B. Tables}

\section{B.1. First stage model, pooled probit}

Table D.6: Treatment models predicting the likelihood of financial crises, pooled probit, average marginal effects

\begin{tabular}{|c|c|c|c|}
\hline & (1) & $(2)$ & (3) \\
\hline & Debt & Banking & Currency \\
\hline \multirow[t]{2}{*}{ \# of Debt crises over past-5 years $(\mathrm{t}-5, \mathrm{t})$} & & -0.012 & $0.034^{* *}$ \\
\hline & & $(0.022)$ & $(0.014)$ \\
\hline \multirow[t]{2}{*}{$\#$ of Banking crises over past- 5 years $(t-5, t)$} & 0.026 & & $0.060 * * *$ \\
\hline & $(0.016)$ & & $(0.016)$ \\
\hline \multirow[t]{2}{*}{$\#$ of Currency crises over past- 5 years $(t-5, t)$} & 0.018 & 0.010 & \\
\hline & $(0.016)$ & $(0.023)$ & \\
\hline \multirow[t]{2}{*}{ Intensity of conflicts $(\mathrm{t}-1)$} & -0.004 & -0.002 & -0.006 \\
\hline & $(0.004)$ & $(0.004)$ & $(0.004)$ \\
\hline \multirow{2}{*}{ Log of real GDP (t-1) } & -0.001 & -0.002 & $-0.005 * *$ \\
\hline & $(0.002)$ & $(0.002)$ & $(0.002)$ \\
\hline \multirow[t]{2}{*}{ Log. of public debt to GDP (t-1) } & $0.042 * * *$ & 0.004 & -0.002 \\
\hline & $(0.015)$ & $(0.013)$ & $(0.012)$ \\
\hline \multirow[t]{2}{*}{ Log. of domestic credit to GDP (t-1) } & 0.010 & $0.049 * * *$ & 0.010 \\
\hline & $(0.015)$ & $(0.019)$ & $(0.014)$ \\
\hline \multirow{2}{*}{ Log. of liquid liabilities to GDP (t-1) } & -0.026 & $-0.051 * *$ & 0.019 \\
\hline & $(0.019)$ & $(0.022)$ & $(0.019)$ \\
\hline \multirow[t]{2}{*}{ Net capital inflows to GDP (t-1) } & 0.002 & 0.001 & 0.002 \\
\hline & $(0.005)$ & $(0.007)$ & $(0.005)$ \\
\hline \multirow[t]{2}{*}{ Log. of foreign reserves to GDP (t-1) } & $-0.038 * * *$ & -0.013 & $-0.034 * * *$ \\
\hline & $(0.010)$ & $(0.012)$ & $(0.011)$ \\
\hline \multirow{2}{*}{ Current account to GDP (t-1) } & 0.003 & -0.001 & -0.002 \\
\hline & $(0.005)$ & $(0.007)$ & $(0.005)$ \\
\hline \multirow[t]{2}{*}{ Financial openness index $(\mathrm{t}-1)$} & $0.051^{*}$ & -0.035 & -0.002 \\
\hline & $(0.027)$ & $(0.026)$ & $(0.026)$ \\
\hline \multirow[t]{2}{*}{ Log of trade openness to GDP (t-1) } & 0.008 & -0.015 & $-0.038 * *$ \\
\hline & $(0.017)$ & $(0.018)$ & $(0.017)$ \\
\hline \multirow[t]{2}{*}{ Terms of trade growth $(\mathrm{t}-1)$} & 0.000 & 0.107 & 0.050 \\
\hline & $(0.101)$ & $(0.132)$ & $(0.104)$ \\
\hline \multirow[t]{2}{*}{ Floating exchange rate regime $(\mathrm{t}-1)$} & $0.054 * * *$ & -0.028 & $0.047 * *$ \\
\hline & $(0.020)$ & $(0.030)$ & $(0.018)$ \\
\hline \multirow[t]{2}{*}{ Government accountability index } & -0.000 & -0.000 & -0.009 \\
\hline & $(0.012)$ & $(0.012)$ & $(0.011)$ \\
\hline \multirow[t]{2}{*}{ Corruption index } & -0.008 & 0.002 & 0.003 \\
\hline & $(0.034)$ & $(0.036)$ & $(0.035)$ \\
\hline \multirow[t]{2}{*}{ Trading partners' growth (t-1) } & $-0.010 * *$ & $0.010 * *$ & 0.001 \\
\hline & $(0.004)$ & $(0.005)$ & $(0.004)$ \\
\hline \multirow[t]{2}{*}{ US interest rate on gov.'s debt securities ( $\mathrm{t}-1$ ) } & $0.004 * *$ & 0.002 & -0.001 \\
\hline & $(0.002)$ & $(0.002)$ & $(0.002)$ \\
\hline Observations & 732 & 732 & 732 \\
\hline \# of crises & 38 & 34 & 36 \\
\hline Classification & 94.262 & 95.219 & 95.082 \\
\hline Model AUC & 0.922 & 0.769 & 0.915 \\
\hline s.e. AUC & 0.016 & 0.038 & 0.019 \\
\hline pseudo R2 & 0.338 & 0.121 & 0.343 \\
\hline
\end{tabular}




\section{B.2. Benchmark and robustness results}

Table D.7: Benchmark results, Cumulative trade losses over five years after financial crises

\begin{tabular}{|c|c|c|c|c|c|c|c|c|c|c|c|c|c|}
\hline \multicolumn{7}{|c|}{ Panel I: Exports (percent of pre-crisis GDP) } & \multicolumn{7}{|c|}{ Panel II: Imports (percent of pre-crisis GDP) } \\
\hline & (1) & (2) & (3) & (4) & (5) & (6) & & (1) & (2) & (3) & (4) & (5) & (6) \\
\hline & $\mathrm{h}=\mathbf{0}$ & $h=1$ & $\mathrm{~h}=2$ & $\mathrm{~h}=3$ & $h=4$ & $h=5$ & & $h=0$ & $\mathrm{~h}=1$ & $h=2$ & $\mathrm{~h}=\mathbf{3}$ & $h=4$ & $\mathrm{~h}=5$ \\
\hline \multicolumn{7}{|l|}{ Panel A: Debt Crises } & \multicolumn{7}{|l|}{ Panel A': Debt Crises } \\
\hline ATE-AIPW Total & $\begin{array}{c}-0.134 \\
(0.342)\end{array}$ & $\begin{array}{c}-3.415 * * * \\
(0.466)\end{array}$ & $\begin{array}{c}-3.348 * * * * \\
(0.597)\end{array}$ & $\begin{array}{c}-5.925 * * * * \\
(0.860)\end{array}$ & $\begin{array}{c}-6.413^{* * * *} \\
(1.093)\end{array}$ & $\begin{array}{c}-5.639 * * * \\
(1.514)\end{array}$ & ATE-AIPW Total & $\begin{array}{c}-4.397 * * * * \\
(0.471)\end{array}$ & $\begin{array}{c}-8.365 * * * \\
(0.649)\end{array}$ & $\begin{array}{c}-9.358^{* * * *} \\
(1.004)\end{array}$ & $\begin{array}{c}-10.403 * * * \\
(1.322)\end{array}$ & $\begin{array}{c}-11.188 * * * \\
(1.668)\end{array}$ & $\begin{array}{c}-11.012 * * * * \\
(2.246)\end{array}$ \\
\hline ATE-AIPW Agriculture & $\begin{array}{l}-0.146 \\
(0.122)\end{array}$ & $\begin{array}{l}-0.048 \\
(0.141)\end{array}$ & $\begin{array}{l}0.382^{* *} \\
(0.184)\end{array}$ & $\begin{array}{c}0.364 \\
(0293)\end{array}$ & $\begin{array}{l}0.846 * * \\
(0.395)\end{array}$ & $\begin{array}{c}2.248^{* * * *} \\
(0.623)\end{array}$ & ATE-AIPW Agriculture & $\begin{array}{l}-0.375^{* * * *} \\
(0.073)\end{array}$ & $\begin{array}{c}-0.822 * * * \\
(0.081)\end{array}$ & $\begin{array}{c}-0.810^{* * * *} \\
(0.134)\end{array}$ & $\begin{array}{c}-1.069 * * * \\
(0.159)\end{array}$ & $\begin{array}{l}-1.363 * * * \\
(0.188)\end{array}$ & $\begin{array}{c}-1.077^{* * *} \\
(0.245)\end{array}$ \\
\hline ATE-AIPW Mining & $\begin{array}{l}1.420^{* * * *} \\
(0.215)\end{array}$ & $\begin{array}{l}-0.404^{*} \\
(0.226)\end{array}$ & $\begin{array}{l}-0.013 \\
(0.260)\end{array}$ & $\begin{array}{l}-0.639^{*} \\
(0.351)\end{array}$ & $\begin{array}{l}-0.263 \\
(0.425)\end{array}$ & $\begin{array}{l}1.068^{*} \\
(0.590)\end{array}$ & ATE-AIPW Mining & $\begin{array}{c}-0.644 * * * * \\
(0.093)\end{array}$ & $\begin{array}{c}-1.492 * * * \\
(0.156)\end{array}$ & $\begin{array}{c}-1.664 * * * \\
(0.215)\end{array}$ & $\begin{array}{c}-2.103 * * * \\
(0.298)\end{array}$ & $\begin{array}{c}-1.934 * * * \\
(0.381)\end{array}$ & $\begin{array}{c}-1.927 * * * \\
(0.531)\end{array}$ \\
\hline ATE-AIPW Manufacturing & $\begin{array}{c}-0.862^{2 * * *} \\
(0.145)\end{array}$ & $\begin{array}{c}-2.026 * * * \\
(0.257)\end{array}$ & $\begin{array}{c}-2.605 * * * \\
(0.327)\end{array}$ & $\begin{array}{c}-4.057 * * * * \\
(0.418)\end{array}$ & $\begin{array}{c}-5.098 * * * \\
(0.540)\end{array}$ & $\begin{array}{c}-6.065 * * * \\
(0.736)\end{array}$ & ATE-AIPW Manufacturing & $\begin{array}{c}-2.265 * * * \\
(0.305)\end{array}$ & $\begin{array}{c}-4.432 * * * \\
(0.414)\end{array}$ & $\begin{array}{c}-4.456 * * * \\
(0.612)\end{array}$ & $\begin{array}{c}-4.730 * * * \\
(0.800)\end{array}$ & $\begin{array}{c}-5.207 * * * \\
(1.011)\end{array}$ & $\begin{array}{c}-5.388 * * * \\
(1.358)\end{array}$ \\
\hline ATE-AIPW Services & $\begin{array}{c}-0.546 * * * * * \\
(0.082)\end{array}$ & $\begin{array}{c}-0.936 * * * * \\
(0.128) \\
\end{array}$ & $\begin{array}{c}-1.113 * * * * \\
(0.187)\end{array}$ & $\begin{array}{c}-1.592 * * * * \\
(0.246)\end{array}$ & $\begin{array}{c}-1.898^{* * * * *} \\
(0.293)\end{array}$ & $\begin{array}{c}-2.890 * * * * \\
(0.380) \\
\end{array}$ & ATE-AIPW Services & $\begin{array}{c}-1.113 * * * * \\
(0.114)\end{array}$ & $\begin{array}{c}-1.619 * * * \\
(0.153) \\
\end{array}$ & $\begin{array}{c}-2.429 * * * * \\
(0.209)\end{array}$ & $\begin{array}{c}-2.502 * * * \\
(0.241)\end{array}$ & $\begin{array}{c}-2.685 * * * * \\
(0.290)\end{array}$ & $\begin{array}{c}-2.611^{* * * *} \\
(0.346) \\
\end{array}$ \\
\hline Observations & 732 & 732 & 732 & 732 & 732 & 732 & Observations & 732 & 732 & 732 & 732 & 732 & 732 \\
\hline \# of Crises & 38 & 38 & 38 & 38 & 38 & 38 & \# of Crises & 38 & 38 & 38 & 38 & 38 & 38 \\
\hline \# of Countries & 41 & 41 & 41 & 41 & 41 & 41 & \# of Countries & 41 & 41 & 41 & 41 & 41 & 41 \\
\hline P-value Total Exports= Total Imports & 0.000 & 0.000 & 0.000 & 0.000 & 0.000 & 0.231 & $\underline{P \text {-value Total Exports= Total Imports }}$ & 0.000 & 0.000 & 0.000 & 0.000 & 0.000 & 0.231 \\
\hline \multicolumn{7}{|l|}{ Panel B: Banking Crises } & \multicolumn{7}{|l|}{ Panel B': Banking Crises } \\
\hline ATE-AIPW Total & $\begin{array}{c}-1.274 * * * * \\
(0.321)\end{array}$ & $\begin{array}{c}-4.957 * * * \\
(0.519)\end{array}$ & $\begin{array}{l}-5.561 * * * \\
(0.618)\end{array}$ & $\begin{array}{c}-5.642 * * * \\
(0.747)\end{array}$ & $\begin{array}{c}-8.392^{* * * *} \\
(0.960)\end{array}$ & $\begin{array}{c}-8.943 * * * \\
(1.130)\end{array}$ & ATE-AIPW Total & $\begin{array}{c}-3.208^{* * * *} \\
(0.484)\end{array}$ & $\begin{array}{c}-7.119 * * * \\
(0.840)\end{array}$ & $\begin{array}{c}-9.158^{* * * *} \\
(0.959)\end{array}$ & $\begin{array}{c}-9.746 * * * \\
(1.069)\end{array}$ & $\begin{array}{c}-11.466 * * * \\
(1.388)\end{array}$ & $\begin{array}{c}-14.059 * * * \\
(1.571)\end{array}$ \\
\hline ATE-AIPW Agriculture & $\begin{array}{l}-0.086 \\
(0.070)\end{array}$ & $\begin{array}{c}-0.403 * * * * \\
(0.097)\end{array}$ & $\begin{array}{c}-0.724 * * * * \\
(0.133)\end{array}$ & $\begin{array}{c}-0.885 * * * \\
(0.158)\end{array}$ & $\begin{array}{c}-1.071^{* * * *} \\
(0.192)\end{array}$ & $\begin{array}{c}-1.530 * * * \\
(0.212)\end{array}$ & ATE-AIPW Agriculture & $\begin{array}{c}-0.248^{* * * *} \\
(0.081)\end{array}$ & $\begin{array}{c}0.027 \\
(0.139)\end{array}$ & $\begin{array}{c}-0.417 * * * \\
(0.149)\end{array}$ & $\begin{array}{c}-0.732 * * * \\
(0.149)\end{array}$ & $\begin{array}{c}-0.962 * * * \\
(0.180)\end{array}$ & $\begin{array}{c}-1.493 * * * \\
(0.173)\end{array}$ \\
\hline ATE-AIPW Mining & $\begin{array}{l}-0.156 \\
(0.165)\end{array}$ & $\begin{array}{c}-0.857 * * * * \\
(0.238)\end{array}$ & $\begin{array}{c}-0.824 * * * \\
(0.280)\end{array}$ & $\begin{array}{c}-1.185^{* * * *} \\
(0.315)\end{array}$ & $\begin{array}{c}-2.262 * * * * \\
(0.353)\end{array}$ & $\begin{array}{c}-1.604 * * * \\
(0.480)\end{array}$ & ATE-AIPW Mining & $\begin{array}{c}-0.666^{* * * * *} \\
(0.112)\end{array}$ & $\begin{array}{c}-1.310^{* * * *} \\
(0.163)\end{array}$ & $\begin{array}{c}-1.669 * * * \\
(0.185)\end{array}$ & $\begin{array}{c}-1.938 * * * \\
(0.222)\end{array}$ & $\begin{array}{c}-2.421 * * * * \\
(0.271)\end{array}$ & $\begin{array}{c}-2.934 * * * \\
(0.307)\end{array}$ \\
\hline ATE-AIPW Manufacturing & $\begin{array}{c}-0.362^{* * *} \\
(0.152)\end{array}$ & $\begin{array}{c}-1.853 * * * \\
(0.305)\end{array}$ & $\begin{array}{c}-1.830^{* * * *} \\
(0.385)\end{array}$ & $\begin{array}{c}-1.399 * * * * \\
(0.480)\end{array}$ & $\begin{array}{c}-2.065 * * * \\
(0.599)\end{array}$ & $\begin{array}{c}-2.326 * * * \\
(0.728)\end{array}$ & ATE-AIPW Manufacturing & $\begin{array}{c}-1.880^{* * * *} \\
(0.271)\end{array}$ & $\begin{array}{c}-4.767 * * * \\
(0.509)\end{array}$ & $\begin{array}{c}-5.380 * * * \\
(0.578)\end{array}$ & $\begin{array}{c}-5.140 * * * \\
(0.644)\end{array}$ & $\begin{array}{c}-5.748 * * * \\
(0.849)\end{array}$ & $\begin{array}{c}-7.038 * * * \\
(0.989)\end{array}$ \\
\hline ATE-AIPW Services & $\begin{array}{c}-0.669^{* * * *} \\
(0.102)\end{array}$ & $\begin{array}{c}-1.844 * * * \\
(0.170)\end{array}$ & $\begin{array}{c}-2.183 * * * \\
(0.238)\end{array}$ & $\begin{array}{c}-2.174 * * * * \\
(0.318)\end{array}$ & $\begin{array}{c}-2.994 * * * * \\
(0.394)\end{array}$ & $\begin{array}{c}-3.484 * * * \\
(0.503) \\
\end{array}$ & ATE-AIPW Services & $\begin{array}{c}-0.414 * * * * \\
(0.108)\end{array}$ & $\begin{array}{c}-1.070 * * * * \\
(0.134)\end{array}$ & $\begin{array}{c}-1.692^{* * *} \\
(0.187)\end{array}$ & $\begin{array}{c}-1.937 * * * \\
(0.219)\end{array}$ & $\begin{array}{c}-2.334 * * * \\
(0.262)\end{array}$ & $\begin{array}{c}-2.594 * * * \\
(0.293)\end{array}$ \\
\hline Observations & 732 & 732 & 732 & 732 & 732 & 732 & Observations & 732 & 732 & 732 & 732 & 732 & 732 \\
\hline \# of Crises & 34 & 34 & 34 & 34 & 34 & 34 & \# of Crises & 34 & 34 & 34 & 34 & 34 & 34 \\
\hline \# of Countries & 41 & 41 & 41 & 41 & 41 & 41 & \# of Countries & 41 & 41 & 41 & 41 & 41 & 41 \\
\hline P-value Total Exports= Total Imports & 0.019 & 0.000 & 0.002 & 0.250 & 0.008 & 0.011 & P-value Total Exports= Total Imports & 0.019 & 0.000 & 0.002 & 0.250 & 0.008 & 0.011 \\
\hline \multicolumn{7}{|l|}{ Panel C: Currency Crises } & \multicolumn{7}{|l|}{ Panel C': Currency Crises } \\
\hline ATE-AIPW Total & $\begin{array}{c}-4.435 * * * \\
(0.356)\end{array}$ & $\begin{array}{c}-4.198 * * * \\
(0.440)\end{array}$ & $\begin{array}{c}-4.901 * * * * \\
(0.616)\end{array}$ & $\begin{array}{c}-5.135 * * * \\
(0.776)\end{array}$ & $\begin{array}{c}-6.757^{* * * *} \\
(0.896)\end{array}$ & $\begin{array}{c}-7.702 * * * \\
(1.113)\end{array}$ & ATE-AIPW Total & $\begin{array}{c}-8.533 * * * * \\
(0.506)\end{array}$ & $\begin{array}{c}-9.463 * * * \\
(0.629)\end{array}$ & $\begin{array}{c}-9.255 * * * \\
(0.871)\end{array}$ & $\begin{array}{c}-10.500 * * * * \\
(1.098)\end{array}$ & $\begin{array}{c}-10.630 * * * \\
(1.308)\end{array}$ & $\begin{array}{c}-9.105 * * * \\
(1.640)\end{array}$ \\
\hline ATE-AIPW Agriculture & $\begin{array}{l}-0.037 \\
(0.076)\end{array}$ & $\begin{array}{c}-0.257 * * \\
(0.123)\end{array}$ & $\begin{array}{l}-0.234 \\
(0.230)\end{array}$ & $\begin{array}{l}-0.261 \\
(0.250)\end{array}$ & $\begin{array}{l}-0.079 \\
(0.235)\end{array}$ & $\begin{array}{c}0.039 \\
(0.317)\end{array}$ & ATE-AIPW Agriculture & $\begin{array}{c}-0.761 * * * \\
(0.084)\end{array}$ & $\begin{array}{c}-0.764 * * * \\
(0.078)\end{array}$ & $\begin{array}{c}-0.838^{* * *} \\
(0.105)\end{array}$ & $\begin{array}{c}-1.080^{* * *} \\
(0.118)\end{array}$ & $\begin{array}{c}-0.831 * * * \\
(0.144)\end{array}$ & $\begin{array}{c}-0.667 * * * \\
(0.170)\end{array}$ \\
\hline ATE-AIPW Mining & $\begin{array}{c}-0.898 * * * * \\
(0.204)\end{array}$ & $\begin{array}{c}-1.053 * * * \\
(0.176)\end{array}$ & $\begin{array}{c}-1.591 * * * * \\
(0.263)\end{array}$ & $\begin{array}{c}-1.548^{* * * * *} \\
(0.296)\end{array}$ & $\begin{array}{c}-2.404 * * * * \\
(0.336)\end{array}$ & $\begin{array}{c}-2.896 * * * \\
(0.402)\end{array}$ & ATE-AIPW Mining & $\begin{array}{c}-1.765 * * * \\
(0.112)\end{array}$ & $\begin{array}{c}-1.508 * * * \\
(0.144)\end{array}$ & $\begin{array}{c}-1.952 * * * \\
(0.209)\end{array}$ & $\begin{array}{c}-2.263 * * * \\
(0.250)\end{array}$ & $\begin{array}{c}-2.978 * * * \\
(0.282)\end{array}$ & $\begin{array}{c}-2.957 * * * \\
(0.389)\end{array}$ \\
\hline ATE-AIPW Manufacturing & $\begin{array}{c}-2.578 * * * * \\
(0.195)\end{array}$ & $\begin{array}{c}-2.282 * * * \\
(0.256)\end{array}$ & $\begin{array}{c}-2.584 * * * \\
(0.314)\end{array}$ & $\begin{array}{c}-3.127 * * * * \\
(0.416)\end{array}$ & $\begin{array}{c}-3.852^{* * * *} \\
(0.507)\end{array}$ & $\begin{array}{c}-3.959 * * * \\
(0.616)\end{array}$ & ATE-AIPW Manufacturing & $\begin{array}{c}-4.930 * * * \\
(0.311)\end{array}$ & $\begin{array}{c}-5.963 * * * \\
(0.392)\end{array}$ & $\begin{array}{c}-5.179 * * * \\
(0.514)\end{array}$ & $\begin{array}{c}-5.839 * * * \\
(0.642)\end{array}$ & $\begin{array}{c}-5.801 * * * \\
(0.778)\end{array}$ & $\begin{array}{c}-4.557 * * * \\
(0.948)\end{array}$ \\
\hline ATE-AIPW Services & $\begin{array}{c}-0.923 * * * * \\
(0.089)\end{array}$ & $\begin{array}{c}-0.605 * * * * \\
(0.150)\end{array}$ & $\begin{array}{c}-0.491 * * \\
(0.211)\end{array}$ & $\begin{array}{r}-0.199 \\
(0.315)\end{array}$ & $\begin{array}{c}-0.422 \\
(0.352)\end{array}$ & $\begin{array}{c}-0.886^{* *} \\
(0.407)\end{array}$ & ATE-AIPW Services & $\begin{array}{c}-1.077 * * * * \\
(0.087)\end{array}$ & $\begin{array}{c}-1.229 * * * \\
(0.131)\end{array}$ & $\begin{array}{c}-1.286^{* * *} \\
(0.191)\end{array}$ & $\begin{array}{c}-1.318 * * * \\
(0.244)\end{array}$ & $\begin{array}{c}-1.021 * * * \\
(0.281)\end{array}$ & $\begin{array}{c}-0.925 * * * \\
(0.312)\end{array}$ \\
\hline Observations & 732 & 732 & 732 & 732 & 732 & 732 & Observations & 732 & 732 & 732 & 732 & 732 & 732 \\
\hline \# of Crises & 36 & 36 & 36 & 36 & 36 & 36 & \# of Crises & 36 & 36 & 36 & 36 & 36 & 36 \\
\hline \# of Countries & 41 & 41 & 41 & 41 & 41 & 41 & \# of Countries & 41 & 41 & 41 & 41 & 41 & 41 \\
\hline P-value Total Exports= Total Imports & 0.093 & 0.000 & 0.000 & 0.000 & 0.004 & 0.879 & P-value Total Exports= Total Imports & 0.093 & 0.000 & 0.000 & 0.000 & 0.004 & 0.879 \\
\hline
\end{tabular}


Table D.8: Robustness, Cumulative trade losses over five years after combined financial crises

\begin{tabular}{|c|c|c|c|c|c|c|}
\hline \multicolumn{7}{|c|}{ Panel I: Exports (\% of pre-crisis GDP) } \\
\hline & (1) & (2) & (3) & (4) & (5) & (6) \\
\hline & $\mathrm{h}=\mathbf{0}$ & $h=1$ & $h=2$ & $\mathrm{~h}=\mathbf{3}$ & $h=4$ & $h=5$ \\
\hline \multicolumn{7}{|l|}{ Panel A: Debt Crises } \\
\hline ATE-AIPW Total & $\begin{array}{c}-2.398^{* * * * *} \\
(0.308)\end{array}$ & $\begin{array}{c}-3.242 * * * * \\
(0.498)\end{array}$ & $\begin{array}{c}-4.211 * * * * \\
(0.652)\end{array}$ & $\begin{array}{c}-7.640 * * * * \\
(0.918)\end{array}$ & $\begin{array}{c}-9.691 * * * * \\
(1.077)\end{array}$ & $\begin{array}{c}-9.805 * * * * \\
(1.328)\end{array}$ \\
\hline ATE-AIPW Agriculture & $\begin{array}{c}-1.190^{* * * *} \\
(0.119)\end{array}$ & $\begin{array}{c}-0.780^{* * * * *} \\
(0.133)\end{array}$ & $\begin{array}{c}-0.609 * * * * \\
(0.187)\end{array}$ & $\begin{array}{c}0.292 \\
(0.297)\end{array}$ & $\begin{array}{c}0.137 \\
(0.318)\end{array}$ & $\begin{array}{c}-0.249 \\
(0.342)\end{array}$ \\
\hline ATE-AIPW Mining & $\begin{array}{c}0.173 \\
(0.119)\end{array}$ & $\begin{array}{c}0.061 \\
(0.230)\end{array}$ & $\begin{array}{c}0.400 \\
(0.272)\end{array}$ & $\begin{array}{c}-1.849 * * * * \\
(0.345)\end{array}$ & $\begin{array}{c}-1.124 * * * * \\
(0.405)\end{array}$ & $\begin{array}{l}1.272 * * \\
(0.575)\end{array}$ \\
\hline ATE-AIPW Manufacturing & $\begin{array}{c}-0.8655^{* * * * * *} \\
(0.150)\end{array}$ & $\begin{array}{c}-1.866 * * * * \\
(0.273)\end{array}$ & $\begin{array}{c}-2.984 * * * * \\
(0.347)\end{array}$ & $\begin{array}{c}-4.990^{* * * * * *} \\
(0.450)\end{array}$ & $\begin{array}{c}-7.223 * * * * * \\
(0.562)\end{array}$ & $\begin{array}{c}-8.395 * * * * \\
(0.673)\end{array}$ \\
\hline ATE-AIPW Services & $\begin{array}{c}-0.517 * * * * * \\
(0.089)\end{array}$ & $\begin{array}{c}-0.658 * * * * \\
(0.144)\end{array}$ & $\begin{array}{c}-1.019 * * * * \\
(0.205)\end{array}$ & $\begin{array}{c}-1.093^{* * * * *} \\
(0.260)\end{array}$ & $\begin{array}{c}-1.481 * * * * \\
(0.303)\end{array}$ & $\begin{array}{c}-2.433 * * * * \\
(0.378) \\
\end{array}$ \\
\hline Observations & 689 & 689 & 689 & 689 & 689 & 689 \\
\hline \# of Crises & 24 & 24 & 24 & 24 & 24 & 24 \\
\hline \# of Countries & 40 & 40 & 40 & 40 & 40 & 40 \\
\hline P-value Total Exports= Total Imports & 0.000 & 0.000 & 0.000 & 0.461 & 0.087 & 0.000 \\
\hline \multicolumn{7}{|l|}{ Panel B: Banking Crises } \\
\hline ATE-AIPW Total & $\begin{array}{c}-0.561 \\
(0.378)\end{array}$ & $\begin{array}{c}-8.605 * * * * \\
(0.488)\end{array}$ & $\begin{array}{c}-6.842 * * * * \\
(0.686)\end{array}$ & $\begin{array}{c}-6.090^{* * * * *} \\
(0.780)\end{array}$ & $\begin{array}{c}-9.662^{* * * * *} \\
(0.910)\end{array}$ & $\begin{array}{c}-12.192 * * * \\
(1.054)\end{array}$ \\
\hline ATE-AIPW Agriculture & $\begin{array}{l}0.140^{*} \\
(0.077)\end{array}$ & $\begin{array}{c}-0.299 * * * \\
(0.091)\end{array}$ & $\begin{array}{c}-0.627 * * * * \\
(0.137)\end{array}$ & $\begin{array}{c}-0.209 \\
(0.172)\end{array}$ & $\begin{array}{l}0.405^{*} \\
(0.213)\end{array}$ & $\begin{array}{c}0.291 \\
(0.229)\end{array}$ \\
\hline ATE-AIPW Mining & $\begin{array}{c}-0.066 \\
(0.154)\end{array}$ & $\begin{array}{c}-1.362 * * * * \\
(0.219)\end{array}$ & $\begin{array}{l}-0.090 \\
(0.314)\end{array}$ & $\begin{array}{c}-0.229 \\
(0.351)\end{array}$ & $\begin{array}{c}-2.077 * * * * \\
(0.417)\end{array}$ & $\begin{array}{c}-2.056 * * * * \\
(0.542)\end{array}$ \\
\hline ATE-AIPW Manufacturing & $\begin{array}{c}-0.155 \\
(0.177)\end{array}$ & $\begin{array}{c}-4.234 * * * * \\
(0.283)\end{array}$ & $\begin{array}{c}-3.686 * * * * \\
(0.354)\end{array}$ & $\begin{array}{c}-3.002 * * * * \\
(0.449)\end{array}$ & $\begin{array}{c}-4.403 * * * * \\
(0.581)\end{array}$ & $\begin{array}{c}-6.214 * * * * \\
(0.703)\end{array}$ \\
\hline ATE-AIPW Services & $\begin{array}{c}-0.481 * * * * \\
(0.114)\end{array}$ & $\begin{array}{c}-2.710^{* * * * *} \\
(0.184) \\
\end{array}$ & $\begin{array}{c}-2.439 * * * * \\
(0.264)\end{array}$ & $\begin{array}{c}-2.650^{* * * * *} \\
(0.328)\end{array}$ & $\begin{array}{c}-3.586^{* * * * *} \\
(0.422)\end{array}$ & $\begin{array}{c}-4.214 * * * * \\
(0.541)\end{array}$ \\
\hline Observations & 689 & 689 & 689 & 689 & 689 & 689 \\
\hline \# of Crises & 17 & 17 & 17 & 17 & 17 & 17 \\
\hline \# of Countries & 40 & 40 & 40 & 40 & 40 & 40 \\
\hline P-value Total Exports= Total Imports & 0.000 & 0.000 & 0.000 & 0.000 & 0.001 & 0.003 \\
\hline \multicolumn{7}{|l|}{ Panel C: Currency Crises } \\
\hline ATE-AIPW Total & $\begin{array}{c}-6.901^{* * * * *} \\
(0.325)\end{array}$ & $\begin{array}{c}-5.610 * * * \\
(0.475)\end{array}$ & $\begin{array}{c}-5.217 * * * * \\
(0.651)\end{array}$ & $\begin{array}{c}-5.917 * * * * \\
(0.877)\end{array}$ & $\begin{array}{c}-8.798 * * * * \\
(0.972)\end{array}$ & $\begin{array}{c}-11.019 * * * * \\
(1.201)\end{array}$ \\
\hline ATE-AIPW Agriculture & $\begin{array}{c}-0.187 * * \\
(0.079)\end{array}$ & $\begin{array}{c}-0.257^{* * *} \\
(0.130)\end{array}$ & $\begin{array}{c}0.088 \\
(0.240)\end{array}$ & $\begin{array}{c}0.677^{* * * *} \\
(0.258)\end{array}$ & $\begin{array}{c}0.608 * * \\
(0.238)\end{array}$ & $\begin{array}{c}0.953 * * * * \\
(0.322)\end{array}$ \\
\hline ATE-AIPW Mining & $\begin{array}{c}-1.031 \text { ***** } \\
(0.115)\end{array}$ & $\begin{array}{c}-1.226 * * * * * \\
(0.220)\end{array}$ & $\begin{array}{c}-1.844 * * * * \\
(0.289)\end{array}$ & $\begin{array}{c}-1.611 \text { **** } \\
(0.299)\end{array}$ & $\begin{array}{c}-2.519 * * * * \\
(0.356)\end{array}$ & $\begin{array}{c}-3.648 * * * * \\
(0.509)\end{array}$ \\
\hline ATE-AIPW Manufacturing & $\begin{array}{c}-4.049^{* * * * *} \\
(0.192)\end{array}$ & $\begin{array}{c}-2.782 * * * * \\
(0.272)\end{array}$ & $\begin{array}{c}-1.980 * * * * \\
(0.344)\end{array}$ & $\begin{array}{c}-2.704 * * * * * \\
(0.446)\end{array}$ & $\begin{array}{c}-4.183 * * * * \\
(0.574)\end{array}$ & $\begin{array}{c}-5.050 * * * * \\
(0.723)\end{array}$ \\
\hline ATE-AIPW Services & $\begin{array}{c}-1.634 * * * * \\
(0.108)\end{array}$ & $\begin{array}{c}-1.344 * * * * \\
(0.166) \\
\end{array}$ & $\begin{array}{c}-1.482 * * * * \\
(0.240)\end{array}$ & $\begin{array}{c}-2.277 * * * * \\
(0.506)\end{array}$ & $\begin{array}{c}-2.705 * * * * \\
(0.479)\end{array}$ & $\begin{array}{c}-3.274 * * * * \\
(0.476)\end{array}$ \\
\hline Observations & 689 & 689 & 689 & 689 & 689 & 689 \\
\hline & 24 & 24 & 24 & 24 & 24 & 24 \\
\hline \# of Countries & 40 & 40 & 40 & 40 & 40 & 40 \\
\hline P-value Total Exports= Total Imports & 0.000 & 0.000 & 0.000 & 0.000 & 0.000 & 0.003 \\
\hline
\end{tabular}

\begin{tabular}{llccccc}
\multicolumn{7}{c}{ Panel II: Imports (\% of pre-crisis GDP) } \\
\hline \multicolumn{7}{c}{$\mathbf{( 1 )}$} \\
\hline
\end{tabular}

Panel B': Banking Crises

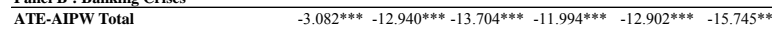

$\begin{array}{lcccccc} & (0.586) & (1.003) & (1.262) & (1.328) & (1.350) & (1.677) \\ \text { ATE-AIPW Agriculture } & -0.382 * * * & -0.907 * * * & -1.271 * * * & -1.427 * * * & -1.606 * * * & -1.840 * * *\end{array}$

$\begin{array}{lllllll} & (0.078) & (0.145) & (0.172) & (0.162) & (0.158) & (0.188) \\ \text { ATE-AIPW Mining } & -0.008 & -1.687 * * * & -1.592 * * * & -1.065 * * & -1.558 * * & -2.685 * * *\end{array}$

$\begin{array}{lcccccc} & (0.128) & (0.199) & (0.242) & (0.275) & (0.295) & (0.347) \\ \text { ATE-AIPW Manufacturing } & -1.882 * * * * & 8.617 * * * & 8.660 * * * & -7.272 * * * & -7.263 * * * & -8.524 * * *\end{array}$

$\begin{array}{lcccccc} & (0.340) & (0.590) & (0.738) & (0.767) & (0.786) & (1.016) \\ \text { ATE-AIPW Services } & -0.810 * * & -1.730 * * * & -2.179 * * * & -2.230 * * * & -2.475 * * * & -2.697 * * *\end{array}$

\begin{tabular}{lcccccc} 
& $(0.109)$ & $(0.141)$ & $(0.195)$ & $(0.235)$ & $(0.252)$ & $(0.276)$ \\
\hline Observations & 17 & 17 & 17 & 689 & 689 & 689
\end{tabular}

Observations

\# of Countrie

\begin{tabular}{lcccccc} 
& 40 & 40 & 40 & 40 & 40 & 40 \\
P-value Total Exports= Total Imports & 0.000 & 0.000 & 0.000 & 0.000 & 0.001 & 0.003 \\
\hline
\end{tabular}

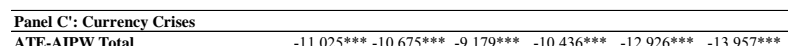
\begin{tabular}{lllllll}
\hline ATE-AIPW Total & $-11.025^{* * *}$ & $-10.675^{* * *}$ & $-9.179^{* * * *}$ & $-10.436^{* * *}$ & $-12.926^{* * * *}$ & $-13.957 * *$ \\
& $(0.495)$ & $(0.653)$ & $(0.852)$ & $(1.251)$ & $(1.401)$ & $(1.697)$
\end{tabular}

ATE-AIPW Agriculture $\quad-0.791 * 0$

$\begin{array}{lllllll} & (0.085) & (0.085) & (0.102) & (0.173) & (0.156) & (0.193) \\ \text { ATE-AIPW Mining } & -2.005 * * * & -1.546 * * * * & -1.128 * * * & -1.537 * * * & -2.557 * * * & -3.148 * * *\end{array}$

$\begin{array}{ccccccc} & -2.005 * * * & -1.546 * * & -1.128 * * & -1.537 * * & -2.557 * * * & -3.148^{* * *} \\ & (0.101) & (0.143) & (0.186) & (0.260) & (0.290) & (0.411)\end{array}$

ATE-AIPW Manufacturing $\quad-6.593 * * * \quad-6.633 * * * \quad-5.223 * * * \begin{array}{lllll}0.535 * * * & -6.925 * * * & -7.226 * * *\end{array}$

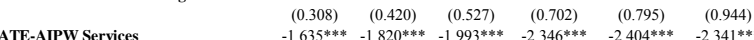

\begin{tabular}{ccccccc}
$(0.095)$ & $(0.122)$ & $(0.179)$ & $(0.345)$ & $(0.384)$ & $(0.356)$ \\
\hline
\end{tabular}

\begin{tabular}{lcccccc} 
& $(0.095)$ & $(0.122)$ & $(0.179)$ & $(0.345)$ & $(0.384)$ & $(0.356)$ \\
\hline Observations & 689 & 689 & 689 & 689 & 689 & 689
\end{tabular}

\begin{tabular}{lcccc} 
\# of Countries & 40 & 40 & 40 & 40 \\
P-value Total Exports= Total Imports & 0.000 & 0.000 & 0.000 & 0.000 \\
\hline
\end{tabular}

Pes. The dependent variables are 100 times the cumulative change of agricultural, mining manufacturing, services, and total exports and imports relative to the year prior to the onset of the crisis for years $1-5$

aled pre-crisis GDP. Accumulated costs over five years. Observations in the treated and control groups are weighted by ensity scores predicted in the treatment model. Maximum weights truncated at 10. 
Table D.9: Robustness, Cumulative trade losses over five years after individual financial crises

\begin{tabular}{|c|c|c|c|c|c|c|c|c|c|c|c|c|c|}
\hline \multicolumn{7}{|c|}{ Panel I: Exports (\% of pre-crisis GDP) } & \multicolumn{7}{|c|}{ Panel II: Imports (\% of pre-crisis GDP) } \\
\hline & (1) & (2) & (3) & (4) & (5) & (6) & & (1) & (2) & (3) & (4) & (5) & (6) \\
\hline & $h=0$ & $h=1$ & $h=2$ & $h=3$ & $h=4$ & $h=5$ & & $h=0$ & $h=1$ & $h=2$ & $h=3$ & $h=4$ & $h=5$ \\
\hline \multicolumn{7}{|l|}{ Panel A: Debt Crises } & \multicolumn{7}{|l|}{ Panel A': Debt Crises } \\
\hline ATE-AIPW Total & $\begin{array}{c}2.186^{* * * *} \\
(0.433)\end{array}$ & $\begin{array}{c}-3.367 * * * \\
(0.601)\end{array}$ & $\begin{array}{c}-2.720^{* * * *} \\
(0.880)\end{array}$ & $\begin{array}{c}-4.850^{* * * *} \\
(1.331)\end{array}$ & $\begin{array}{c}-4.808 * * * \\
(1.572)\end{array}$ & $\begin{array}{l}-3.521^{*} \\
(1.899)\end{array}$ & ATE-AIPW Total & $\begin{array}{c}-4.211 * * * \\
(0.464)\end{array}$ & $\begin{array}{c}-10.576^{* * * *} \\
(0.662)\end{array}$ & $\begin{array}{c}-10.066 * * * \\
(1.140)\end{array}$ & $\begin{array}{c}-12.441 * * * \\
(1.468)\end{array}$ & $\begin{array}{c}-14.970 * * * \\
(2.040)\end{array}$ & $\begin{array}{c}-16.934 * * * \\
(2.776)\end{array}$ \\
\hline ATE-AIPW Agriculture & $\begin{array}{c}0.658^{* * * *} \\
(0.075)\end{array}$ & $\begin{array}{c}0.375 * * * \\
(0.121)\end{array}$ & $\begin{array}{l}0.950^{* * * *} \\
(0.163)\end{array}$ & $\begin{array}{c}0.827 * * * * \\
(0.215)\end{array}$ & $\begin{array}{c}1.417 * * * \\
(0.313)\end{array}$ & $\begin{array}{c}3.495 * * * \\
(0.390)\end{array}$ & ATE-AIPW Agriculture & $\begin{array}{c}-0.408 * * * * \\
(0.115)\end{array}$ & $\begin{array}{c}-1.204 * * * \\
(0.122)\end{array}$ & $\begin{array}{c}-0.994 * * * \\
(0.164)\end{array}$ & $\begin{array}{c}-1.448 * * * \\
(0.185)\end{array}$ & $\begin{array}{c}-1.759 * * * \\
(0.243)\end{array}$ & $\begin{array}{c}-1.679 * * * \\
(0.317)\end{array}$ \\
\hline ATE-AIPW Mining & $\begin{array}{c}2.403^{* * * *} \\
(0.252)\end{array}$ & $\begin{array}{c}-1.013^{* * * * *} \\
(0.268)\end{array}$ & $\begin{array}{l}-0.450 \\
(0.346)\end{array}$ & $\begin{array}{l}-0.211 \\
(0.432)\end{array}$ & $\begin{array}{l}-0.239 \\
(0.597)\end{array}$ & $\begin{array}{c}0.666 \\
(0.606)\end{array}$ & ATE-AIPW Mining & $\begin{array}{c}-0.712 * * * * \\
(0.107)\end{array}$ & $\begin{array}{c}-2.037 * * * \\
(0.153)\end{array}$ & $\begin{array}{c}-1.914 * * * \\
(0.255)\end{array}$ & $\begin{array}{c}-2.991 * * * * \\
(0.334)\end{array}$ & $\begin{array}{c}-3.302 * * * \\
(0.446)\end{array}$ & $\begin{array}{c}-3.217 * * * * \\
(0.601)\end{array}$ \\
\hline ATE-AIPW Manufacturing & $\begin{array}{c}-0.452^{* * *} \\
(0.183)\end{array}$ & $\begin{array}{c}-1.633 * * * \\
(0.322)\end{array}$ & $\begin{array}{c}-1.917 * * * * \\
(0.454)\end{array}$ & $\begin{array}{c}-3.110^{\text {******* }} \\
(0.722)\end{array}$ & $\begin{array}{c}-3.241 * * * * \\
(0.793)\end{array}$ & $\begin{array}{c}-3.648 * * * * \\
(0.993)\end{array}$ & ATE-AIPW Manufacturing & $\begin{array}{c}-2.3011^{* * * * *} \\
(0.276)\end{array}$ & $\begin{array}{c}-5.782 * * * \\
(0.420)\end{array}$ & $\begin{array}{c}-4.867 * * * * \\
(0.673)\end{array}$ & $\begin{array}{c}-5.891 * * * * \\
(0.855)\end{array}$ & $\begin{array}{c}-7.210^{* * * *} \\
(1.187)\end{array}$ & $\begin{array}{c}-8.958 * * * * \\
(1.617)\end{array}$ \\
\hline ATE-AIPW Services & $\begin{array}{c}-0.422 * * * * \\
(0.162) \\
\end{array}$ & $\begin{array}{c}-1.096^{* * * *} \\
(0.195) \\
\end{array}$ & $\begin{array}{c}-1.303 * * * \\
(0.283) \\
\end{array}$ & $\begin{array}{c}-2.356 \text { **** } \\
(0.388) \\
\end{array}$ & $\begin{array}{c}-2.745^{* * * *} \\
(0.442) \\
\end{array}$ & $\begin{array}{c}-4.035 * * * \\
(0.557) \\
\end{array}$ & ATE-AIPW Services & $\begin{array}{c}-0.791 * * * * \\
(0.094) \\
\end{array}$ & $\begin{array}{c}-1.553 * * * \\
(0.136) \\
\end{array}$ & $\begin{array}{c}-2.291 * * * \\
(0.210) \\
\end{array}$ & $\begin{array}{c}-2.110 * * * \\
(0.282) \\
\end{array}$ & $\begin{array}{c}-2.699 * * * * \\
(0.355) \\
\end{array}$ & $\begin{array}{c}-3.080 * * * \\
(0.451) \\
\end{array}$ \\
\hline Observations & 670 & 670 & 670 & 670 & 670 & 670 & Observations & 670 & 670 & 670 & 670 & 670 & 670 \\
\hline \# of Crises & 13 & 13 & 13 & 13 & 13 & 13 & \# of Crises & 13 & 13 & 13 & 13 & 13 & 13 \\
\hline \# of Countries & 40 & 40 & 40 & 40 & 40 & 40 & of Countries & 40 & 40 & 40 & 40 & 40 & 40 \\
\hline P-value Total Exports= Total Imports & 0.000 & 0.000 & 0.000 & 0.000 & 0.000 & 0.000 & P-value Total Exports= Total Imports & 0.000 & 0.000 & 0.000 & 0.000 & 0.000 & 0.000 \\
\hline \multicolumn{7}{|l|}{ Panel B: Banking } & \multicolumn{7}{|l|}{ Panel B': Banking Crises } \\
\hline ATE-AIPW Total & $\begin{array}{c}-1.570^{* * * * *} \\
(0.403)\end{array}$ & $\begin{array}{c}-4.914 * * * \\
(0.548)\end{array}$ & $\begin{array}{c}-5.442 * * * * \\
(0.651)\end{array}$ & $\begin{array}{c}-5.659 \text { **** } \\
(0.833)\end{array}$ & $\begin{array}{c}-8.415^{* * * *} \\
(1.199)\end{array}$ & $\begin{array}{c}-7.794 * * * \\
(1.225)\end{array}$ & ATE-AIPW Total & $\begin{array}{c}-4.305^{* * * *} \\
(0.524)\end{array}$ & $\begin{array}{c}-8.532 * * * \\
(1.021)\end{array}$ & $\begin{array}{c}-8.706 * * * \\
(1.163)\end{array}$ & $\begin{array}{c}-10.003 * * * \\
(1.462)\end{array}$ & $\begin{array}{c}-12.822 * * * \\
(2.028)\end{array}$ & $\begin{array}{c}-13.706 * * * \\
(2.020)\end{array}$ \\
\hline ATE-AIPW Agriculture & $\begin{array}{l}-0.037 \\
(0.076)\end{array}$ & $\begin{array}{c}-0.490^{* * * *} \\
(0.128)\end{array}$ & $\begin{array}{c}-0.578 * * * * \\
(0.146)\end{array}$ & $\begin{array}{c}-0.848^{* * * * *} \\
(0.170)\end{array}$ & $\begin{array}{c}-1.333 * * * \\
(0.200)\end{array}$ & $\begin{array}{c}-1.901 * * * * \\
(0.211)\end{array}$ & ATE-AIPW Agriculture & $\begin{array}{c}-0.360^{* * * *} \\
(0.085)\end{array}$ & $\begin{array}{c}-0.577 * * * \\
(0.119)\end{array}$ & $\begin{array}{c}-0.639 * * * \\
(0.133)\end{array}$ & $\begin{array}{c}-0.912 * * * \\
(0.177)\end{array}$ & $\begin{array}{c}-1.401 * * * \\
(0.247)\end{array}$ & $\begin{array}{c}-1.545 * * * \\
(0.237)\end{array}$ \\
\hline ATE-AIPW Mining & $\begin{array}{l}-0.117 \\
(0.241)\end{array}$ & $\begin{array}{c}-1.071 * * * \\
(0.185)\end{array}$ & $\begin{array}{c}-1.285 * * * \\
(0.219)\end{array}$ & $\begin{array}{c}-1.546 * * * * \\
(0.295)\end{array}$ & $\begin{array}{c}-2.359 * * * \\
(0.362)\end{array}$ & $\begin{array}{c}-1.226 * * \\
(0.481)\end{array}$ & ATE-AIPW Mining & $\begin{array}{c}-1.018^{* * * *} \\
(0.134)\end{array}$ & $\begin{array}{c}-1.693 * * * \\
(0.231)\end{array}$ & $\begin{array}{c}-2.009 * * * \\
(0.256)\end{array}$ & $\begin{array}{c}-2.313 * * * \\
(0.308)\end{array}$ & $\begin{array}{c}-3.181 * * * \\
(0.433)\end{array}$ & $\begin{array}{c}-3.337 * * * * \\
(0.384)\end{array}$ \\
\hline ATE-AIPW Manufacturing & $\begin{array}{c}-0.531^{* * * * *} \\
(0.194)\end{array}$ & $\begin{array}{c}-1.537 * * * \\
(0.332)\end{array}$ & $\begin{array}{c}-1.525 * * * \\
(0.421)\end{array}$ & $\begin{array}{c}-1.280 \text { *** } \\
(0.531)\end{array}$ & $\begin{array}{c}-1.843 * * \\
(0.725)\end{array}$ & $\begin{array}{l}-1.453^{*} \\
(0.783)\end{array}$ & ATE-AIPW Manufacturing & $\begin{array}{c}-2.356^{* * * *} \\
(0.300)\end{array}$ & $\begin{array}{c}-4.814 * * * \\
(0.597)\end{array}$ & $\begin{array}{c}-4.436 * * * \\
(0.662)\end{array}$ & $\begin{array}{c}-5.011 * * * * \\
(0.817)\end{array}$ & $\begin{array}{c}-5.923 * * * * \\
(1.127)\end{array}$ & $\begin{array}{c}-6.444 * * * \\
(1.209)\end{array}$ \\
\hline ATE-AIPW Services & $\begin{array}{c}-0.885^{* * * *} * \\
(0.105)\end{array}$ & $\begin{array}{c}-1.817^{* * * *} \\
(0.186)\end{array}$ & $\begin{array}{c}-2.054 * * * \\
(0.269)\end{array}$ & $\begin{array}{c}-1.986 * * * * \\
(0.373)\end{array}$ & $\begin{array}{c}-2.879 * * * \\
(0.493)\end{array}$ & $\begin{array}{c}-3.215 * * * * \\
(0.594)\end{array}$ & ATE-AIPW Services & $\begin{array}{c}-0.571 * * * \\
(0.099)\end{array}$ & $\begin{array}{c}-1.448 * * * \\
(0.171)\end{array}$ & $\begin{array}{c}-1.622 * * * \\
(0.239)\end{array}$ & $\begin{array}{c}-1.767 * * * \\
(0.295)\end{array}$ & $\begin{array}{c}-2.316^{* * * *} \\
(0.362)\end{array}$ & $\begin{array}{c}-2.380^{* * *} \\
(0.362)\end{array}$ \\
\hline Observations & 681 & 681 & 681 & 681 & 681 & 681 & Observations & 681 & 681 & 681 & 681 & 681 & 681 \\
\hline \# of Crises & 17 & 17 & 17 & 17 & 17 & 17 & \# of Crises & 17 & 17 & 17 & 17 & 17 & 17 \\
\hline \# of Countries & 41 & 41 & 41 & 41 & 41 & 41 & \# of Countries & 41 & 41 & 41 & 41 & 41 & 41 \\
\hline P-value Total Exports= Total Imports & 0.000 & 0.000 & 0.000 & 0.000 & 0.000 & 0.000 & P-value Total Exports= Total Imports & 0.000 & 0.000 & 0.000 & 0.000 & 0.000 & 0.000 \\
\hline Panel C: Currency Crises & & & & & & & Panel C': Currency Crises & & & & & & \\
\hline ATE-AIPW Total & $\begin{array}{c}-2.264 * * * * \\
(0.318)\end{array}$ & $\begin{array}{c}-1.741 * * * \\
(0.478)\end{array}$ & $\begin{array}{c}-4.252 * * * \\
(0.600)\end{array}$ & $\begin{array}{c}-3.546 * * * * \\
(0.811)\end{array}$ & $\begin{array}{c}-2.154^{* * *} \\
(0.954)\end{array}$ & $\begin{array}{c}-2.988 * * \\
(1.183)\end{array}$ & ATE-AIPW Total & $\begin{array}{c}-6.517 * * * * \\
(0.438)\end{array}$ & $\begin{array}{c}-9.494 * * * \\
(0.763)\end{array}$ & $\begin{array}{c}-12.343 * * * \\
(1.090)\end{array}$ & $\begin{array}{c}-12.761 * * * * \\
(1.265)\end{array}$ & $\begin{array}{c}-9.287 * * * \\
(1.490)\end{array}$ & $\begin{array}{c}-6.618 * * * \\
(1.802)\end{array}$ \\
\hline ATE-AIPW Agriculture & $\begin{array}{l}0.112^{*} \\
(0.059)\end{array}$ & $\begin{array}{c}-0.490^{* * * *} \\
(0.094)\end{array}$ & $\begin{array}{c}-0.635 * * * * \\
(0.113)\end{array}$ & $\begin{array}{c}-1.096 \text { **** } \\
(0.149)\end{array}$ & $\begin{array}{c}-0.996 * * * \\
(0.176)\end{array}$ & $\begin{array}{c}-1.036 * * * * \\
(0.223)\end{array}$ & ATE-AIPW Agriculture & $\begin{array}{c}-0.640^{* * * *} \\
(0.058)\end{array}$ & $\begin{array}{c}-1.054^{* * * *} \\
(0.094)\end{array}$ & $\begin{array}{c}-1.334 * * * * \\
(0.138)\end{array}$ & $\begin{array}{c}-1.411 * * * \\
(0.140)\end{array}$ & $\begin{array}{c}-0.832^{* * * *} \\
(0.163)\end{array}$ & $\begin{array}{c}-0.562 * * * * \\
(0.197)\end{array}$ \\
\hline ATE-AIPW Mining & $\begin{array}{c}-1.807 * * * * * \\
(0.216)\end{array}$ & $\begin{array}{c}-1.095 * * * * \\
(0.286)\end{array}$ & $\begin{array}{c}-1.635 * * * \\
(0.268)\end{array}$ & $\begin{array}{c}-2.340^{* * * * *} \\
(0.341)\end{array}$ & $\begin{array}{c}-2.483 * * * * \\
(0.393)\end{array}$ & $\begin{array}{c}-2.801 * * * * \\
(0.559)\end{array}$ & ATE-AIPW Mining & $\begin{array}{c}-2.042^{* * * * *} \\
(0.120)\end{array}$ & $\begin{array}{c}-2.197 * * * * \\
(0.165)\end{array}$ & $\begin{array}{c}-4.469 * * * * \\
(0.287)\end{array}$ & $\begin{array}{c}-4.466 * * * * \\
(0.343)\end{array}$ & $\begin{array}{c}-4.708 * * * * \\
(0.383)\end{array}$ & $\begin{array}{c}-4.350 * * * * \\
(0.453)\end{array}$ \\
\hline ATE-AIPW Manufacturing & $\begin{array}{c}-0.423^{* * * *} \\
(0.151)\end{array}$ & $\begin{array}{c}-0.607 * * * \\
(0.252)\end{array}$ & $\begin{array}{c}-2.625 * * * * \\
(0.331)\end{array}$ & $\begin{array}{c}-2.407 * \text { **** } \\
(0.440)\end{array}$ & $\begin{array}{c}-2.039 * * * * \\
(0.525)\end{array}$ & $\begin{array}{c}-2.206 * * * * \\
(0.628)\end{array}$ & ATE-AIPW Manufacturing & $\begin{array}{c}-3.440^{* * * * *} \\
(0.262)\end{array}$ & $\begin{array}{c}-5.908 * * * * \\
(0.469)\end{array}$ & $\begin{array}{c}-5.938 * * * * \\
(0.645)\end{array}$ & $\begin{array}{c}-6.410 * * * * \\
(0.745)\end{array}$ & $\begin{array}{c}-4.226 * * * * \\
(0.877)\end{array}$ & $\begin{array}{c}-3.079 * * * \\
(1.028)\end{array}$ \\
\hline ATE-AIPW Services & $\begin{array}{c}-0.145 \\
(0.116)\end{array}$ & $\begin{array}{l}0.451^{* *} \\
(0.180)\end{array}$ & $\begin{array}{l}0.642^{* * *} \\
(0.257)\end{array}$ & $\begin{array}{c}2.297 * * * \\
(0.348)\end{array}$ & $\begin{array}{c}3.365 * * * \\
(0.383)\end{array}$ & $\begin{array}{c}3.056^{* * * *} \\
(0.449)\end{array}$ & ATE-AIPW Services & $\begin{array}{c}-0.394 * * * * \\
(0.091)\end{array}$ & $\begin{array}{c}-0.336^{* * *} \\
(0.151)\end{array}$ & $\begin{array}{c}-0.602 * * * \\
(0.192)\end{array}$ & $\begin{array}{l}-0.475^{*} \\
(0.250)\end{array}$ & $\begin{array}{c}0.479 \\
(0.293) \\
\end{array}$ & $\begin{array}{c}1.372^{* * * *} \\
(0.336)\end{array}$ \\
\hline Observations & 681 & 681 & 681 & 681 & 681 & 681 & & 681 & 681 & 681 & 681 & 681 & 681 \\
\hline \# of Crises & 12 & 12 & 1 & 12 & 12 & 12 & & 12 & 12 & 12 & 12 & 12 & 12 \\
\hline \# of Countries & 41 & 41 & 41 & 41 & 41 & 41 & \# of Countries & 41 & 41 & 41 & 41 & 41 & 41 \\
\hline P-value Total Exports= Total Imports & 0.000 & 0.000 & 0.000 & 0.000 & 0.000 & 0.003 & P-value Total Exports= Total Imports & 0.000 & 0.000 & 0.000 & 0.000 & 0.000 & 0.003 \\
\hline
\end{tabular}


Table D.10: Robustness, Drop the period 2008 onwards, Cumulative trade losses over five years after financial crises

\begin{tabular}{|c|c|c|c|c|c|c|}
\hline \multicolumn{7}{|c|}{ Panel I: Exports (\% of pre-crisis GDP) } \\
\hline & (1) & (2) & (3) & (4) & (5) & (6) \\
\hline & $h=0$ & $\mathrm{~h}=1$ & $h=2$ & $h=3$ & $h=4$ & $h=5$ \\
\hline \multicolumn{7}{|l|}{ Panel A: Debt Crises } \\
\hline ATE-AIPW Total & $\begin{array}{c}-0.070 \\
(0.452)\end{array}$ & $\begin{array}{l}-1.142^{* *} \\
(0.567)\end{array}$ & $\begin{array}{c}-0.504 \\
(0.756)\end{array}$ & $\begin{array}{c}-2.795 * * \\
(1.128)\end{array}$ & $\begin{array}{l}-2.855 * * \\
(1.374)\end{array}$ & $\begin{array}{l}-2.373 \\
(1.830)\end{array}$ \\
\hline ATE-AIPW Agriculture & $\begin{array}{c}-0.444^{* * * * *} \\
(0.155)\end{array}$ & $\begin{array}{l}-0.179 \\
(0.151)\end{array}$ & $\begin{array}{l}0.528 * * \\
(0.225)\end{array}$ & $\begin{array}{c}0.544 \\
(0.395)\end{array}$ & $\begin{array}{c}0.584 \\
(0.419)\end{array}$ & $\begin{array}{l}0.929 * * \\
(0.415)\end{array}$ \\
\hline ATE-AIPW Mining & $\begin{array}{l}1.261^{* * * *} \\
(0.303)\end{array}$ & $\begin{array}{l}0.812 * * * \\
(0.312)\end{array}$ & $\begin{array}{l}0.864 * * * * \\
(0.333)\end{array}$ & $\begin{array}{c}-0.201 \\
(0.447)\end{array}$ & $\begin{array}{c}0.247 \\
(0.580)\end{array}$ & $\begin{array}{l}1.634^{*} \\
(0.909)\end{array}$ \\
\hline ATE-AIPW Manufacturing & $\begin{array}{c}-0.487 \text { ***** } \\
(0.150)\end{array}$ & $\begin{array}{l}-1.118^{* * * *} \\
(0.305)\end{array}$ & $\begin{array}{c}-1.414 * * * \\
(0.430)\end{array}$ & $\begin{array}{c}-2.449 * * * * \\
(0.574)\end{array}$ & $\begin{array}{l}-2.896 * * * * \\
(0.729)\end{array}$ & $\begin{array}{c}-3.589 * * * \\
(0.963)\end{array}$ \\
\hline ATE-AIPW Services & $\begin{array}{c}-0.400^{* * * *} \\
(0.106)\end{array}$ & $\begin{array}{c}-0.657 * * * \\
(0.173)\end{array}$ & $\begin{array}{c}-0.481^{*} \\
(0.265)\end{array}$ & $\begin{array}{c}-0.689^{* *} \\
(0.305)\end{array}$ & $\begin{array}{c}-0.790^{* * *} \\
(0.364)\end{array}$ & $\begin{array}{c}-1.348 * * * \\
(0.463)\end{array}$ \\
\hline Observations & 409 & 409 & 409 & 409 & 409 & 409 \\
\hline \# of Crises & 33 & 33 & 33 & 33 & 33 & 33 \\
\hline \# of Countries & 39 & 39 & 39 & 39 & 39 & 39 \\
\hline P-value Total Exports= Total Imports & 0.000 & 0.000 & 0.000 & 0.002 & 0.001 & 0.000 \\
\hline \multicolumn{7}{|l|}{ Panel B: Banking Crises } \\
\hline ATE-AIPW Total & $\begin{array}{c}-1.009^{* * * *} \\
(0.341)\end{array}$ & $\begin{array}{l}-2.124 * * * \\
(0.511)\end{array}$ & $\begin{array}{l}-2.521 * * * \\
(0.668)\end{array}$ & $\begin{array}{c}-2.977^{* * * * *} \\
(0.925)\end{array}$ & $\begin{array}{l}-5.977 * * * \\
(1.226)\end{array}$ & $\begin{array}{c}-7.152 * * * \\
(1.485)\end{array}$ \\
\hline ATE-AIPW Agriculture & $\begin{array}{c}0.070 \\
(0.095)\end{array}$ & $\begin{array}{l}-0.020 \\
(0.131)\end{array}$ & $\begin{array}{l}-0.136 \\
(0.182)\end{array}$ & $\begin{array}{l}-0.281 \\
(0.204)\end{array}$ & $\begin{array}{l}-0.494^{*} \\
(0.257)\end{array}$ & $\begin{array}{c}-0.741 * * * \\
(0.251)\end{array}$ \\
\hline ATE-AIPW Mining & $\begin{array}{l}-0.066 \\
(0.135)\end{array}$ & $\begin{array}{l}-0.018 \\
(0.195)\end{array}$ & $\begin{array}{c}0.176 \\
(0.273)\end{array}$ & $\begin{array}{l}-0.306 \\
(0.315)\end{array}$ & $\begin{array}{c}-1.912 * * * \\
(0.365)\end{array}$ & $\begin{array}{c}-1.305 * * \\
(0.628)\end{array}$ \\
\hline ATE-AIPW Manufacturing & $\begin{array}{c}-0.391 * * \\
(0.165)\end{array}$ & $\begin{array}{c}-0.789^{* *} \\
(0.310)\end{array}$ & $\begin{array}{c}-1.119 * * \\
(0.469)\end{array}$ & $\begin{array}{l}-1.095^{*} \\
(0.635)\end{array}$ & $\begin{array}{c}-1.591 * * \\
(0.794)\end{array}$ & $\begin{array}{c}-2.411^{* *} \\
(1.022)\end{array}$ \\
\hline ATE-AIPW Services & $\begin{array}{l}-0.622^{* * * *} \\
(0.152)\end{array}$ & $\begin{array}{l}-1.297 * * * \\
(0.219)\end{array}$ & $\begin{array}{l}-1.442 * * * \\
(0.301)\end{array}$ & $\begin{array}{l}-1.295^{* * * *} \\
(0.418)\end{array}$ & $\begin{array}{l}-1.981 * * * \\
(0.514)\end{array}$ & $\begin{array}{c}-2.686 * * * \\
(0.632)\end{array}$ \\
\hline \multirow{2}{*}{$\begin{array}{l}\text { Observations } \\
\text { \# of Crises }\end{array}$} & 409 & 409 & 409 & 409 & 409 & 409 \\
\hline & 31 & 31 & 31 & 31 & 31 & 31 \\
\hline \multirow{2}{*}{$\begin{array}{l}\text { \# of Countries } \\
\text { P-value Total Exports= Total Imports }\end{array}$} & 39 & 39 & 39 & 39 & 39 & 39 \\
\hline & 0.002 & 0.003 & 0.012 & 0.119 & 0.837 & 0.342 \\
\hline \multicolumn{7}{|l|}{ Panel C: Currency Crises } \\
\hline ATE-AIPW Total & $\begin{array}{c}-1.166^{* * * *} \\
(0.424)\end{array}$ & $\begin{array}{l}-0.930^{*} \\
(0.511)\end{array}$ & $\begin{array}{c}-2.269 * * * \\
(0.833)\end{array}$ & $\begin{array}{l}-2.112^{*} \\
(1.105)\end{array}$ & $\begin{array}{c}-4.091 * * * \\
(1.337)\end{array}$ & $\begin{array}{c}-7.208 * * * \\
(1.736)\end{array}$ \\
\hline ATE-AIPW Agriculture & $\begin{array}{l}0.244^{* * *} \\
(0.115)\end{array}$ & $\begin{array}{c}0.148 \\
(0.169)\end{array}$ & $\begin{array}{c}0.171 \\
(0.360)\end{array}$ & $\begin{array}{r}-0.159 \\
(0.344)\end{array}$ & $\begin{array}{c}0.347 \\
(0.287)\end{array}$ & $\begin{array}{l}0.542^{*} \\
(0.315)\end{array}$ \\
\hline ATE-AIPW Mining & $\begin{array}{c}-0.365 \\
(0.347)\end{array}$ & $\begin{array}{c}-0.479 \text { *** } \\
(0.219)\end{array}$ & $\begin{array}{c}-1.041 * * * * \\
(0.343)\end{array}$ & $\begin{array}{c}-0.906 * * \\
(0.369)\end{array}$ & $\begin{array}{c}-2.210^{* * * *} \\
(0.407)\end{array}$ & $\begin{array}{c}-3.164 * * * * \\
(0.525)\end{array}$ \\
\hline ATE-AIPW Manufacturing & $\begin{array}{c}-0.564 * * * * \\
(0.163)\end{array}$ & $\begin{array}{l}-0.603^{*} \\
(0.312)\end{array}$ & $\begin{array}{c}-1.686 * * * * \\
(0.447)\end{array}$ & $\begin{array}{c}-2.070^{* * * * *} \\
(0.653)\end{array}$ & $\begin{array}{c}-2.865 * * * * \\
(0.817)\end{array}$ & $\begin{array}{c}-4.210^{* * * * *} \\
(1.038)\end{array}$ \\
\hline ATE-AIPW Services & $\begin{array}{c}-0.482^{* * * * *} \\
(0.106)\end{array}$ & $\begin{array}{c}0.004 \\
(0.172)\end{array}$ & $\begin{array}{c}0.288 \\
(0.279)\end{array}$ & $\begin{array}{c}1.022 * * * \\
(0.393)\end{array}$ & $\begin{array}{c}0.636 \\
(0.458)\end{array}$ & $\begin{array}{c}-0.377 \\
(0.598)\end{array}$ \\
\hline Observations & 409 & 409 & 409 & 409 & 409 & 409 \\
\hline \# of Crises & 33 & 33 & 33 & 33 & 33 & 33 \\
\hline \# of Countries & 39 & 39 & 39 & 39 & 39 & 39 \\
\hline P-value Total Exports= Total Imports & 0.000 & 0.000 & 0.000 & 0.000 & 0.086 & 0.869 \\
\hline
\end{tabular}

\begin{tabular}{|c|c|c|c|c|c|c|}
\hline \multicolumn{7}{|c|}{ Panel II: Imports (\% of pre-crisis GDP) } \\
\hline & (1) & (2) & (3) & (4) & (5) & (6) \\
\hline & $h=0$ & $h=1$ & $h=2$ & $h=3$ & $h=4$ & $h=5$ \\
\hline \multicolumn{7}{|l|}{ Panel A': Debt Crises } \\
\hline ATE-AIPW Total & $\begin{array}{c}-4.044^{* * * * *} \\
(0.649)\end{array}$ & $\begin{array}{c}-6.069^{* * *} \\
(0.850)\end{array}$ & $\begin{array}{c}-5.434 * * * \\
(1.300)\end{array}$ & $\begin{array}{c}-6.101^{* * * *} \\
(1.576)\end{array}$ & $\begin{array}{c}-6.073 * * * \\
(1.858)\end{array}$ & $\begin{array}{c}-8.638^{* * * * *} \\
(2.300)\end{array}$ \\
\hline ATE-AIPW Agriculture & $\begin{array}{c}-0.293 * * \\
(0.148)\end{array}$ & $\begin{array}{c}-0.636 * * * * \\
(0.140)\end{array}$ & $\begin{array}{c}-0.414 * * \\
(0.200)\end{array}$ & $\begin{array}{c}-0.637 * * \\
(0.252)\end{array}$ & $\begin{array}{c}-0.662 * * * \\
(0.211)\end{array}$ & $\begin{array}{c}-0.600 * * \\
(0.270)\end{array}$ \\
\hline ATE-AIPW Mining & $\begin{array}{c}-0.540^{* * * * *} \\
(0.122)\end{array}$ & $\begin{array}{c}-0.489^{* * * *} \\
(0.156)\end{array}$ & $\begin{array}{l}-0.356 \\
(0.217)\end{array}$ & $\begin{array}{c}-0.732 * * \\
(0.318)\end{array}$ & $\begin{array}{c}-0.871 * * \\
(0.416)\end{array}$ & $\begin{array}{c}-1.751 * * * * \\
(0.544)\end{array}$ \\
\hline ATE-AIPW Manufacturing & $\begin{array}{c}-2.178^{* * * * *} \\
(0.419)\end{array}$ & $\begin{array}{c}-3.678^{* * * *} \\
(0.549)\end{array}$ & $\begin{array}{c}-3.045 * * * * \\
(0.817)\end{array}$ & $\begin{array}{c}-3.162 * * * * \\
(0.939)\end{array}$ & $\begin{array}{c}-3.106 * * * \\
(1.116)\end{array}$ & $\begin{array}{c}-4.758 * * * * \\
(1.330)\end{array}$ \\
\hline ATE-AIPW Services & $\begin{array}{c}-1.032^{* * * * *} \\
(0.170)\end{array}$ & $\begin{array}{c}-1.266 * * * * \\
(0.219)\end{array}$ & $\begin{array}{c}-1.619 * * * \\
(0.295)\end{array}$ & $\begin{array}{c}-1.570^{* * * *} \\
(0.314)\end{array}$ & $\begin{array}{c}-1.435 * * * * \\
(0.383)\end{array}$ & $\begin{array}{c}-1.528 * * * * \\
(0.449)\end{array}$ \\
\hline Observations & 409 & 409 & 409 & 409 & 409 & 409 \\
\hline \# of Crises & 33 & 33 & 33 & 33 & 33 & 33 \\
\hline \# of Countries & 39 & 39 & 39 & 39 & 39 & 39 \\
\hline P-value Total Exports= Total Imports & 0.000 & 0.000 & 0.000 & 0.002 & 0.001 & 0.000 \\
\hline \multicolumn{7}{|l|}{ Panel B': Banking Crises } \\
\hline ATE-AIPW Total & $\begin{array}{c}-2.645 * * * \\
(0.535)\end{array}$ & $\begin{array}{c}-3.893 * * * * \\
(0.754)\end{array}$ & $\begin{array}{c}-4.564 * * * \\
(0.992)\end{array}$ & $\begin{array}{c}-4.511 * * * * \\
(1.344)\end{array}$ & $\begin{array}{c}-5.715 * * * \\
(1.993)\end{array}$ & $\begin{array}{c}-8.990 * * * * \\
(2.723)\end{array}$ \\
\hline ATE-AIPW Agriculture & $\begin{array}{c}-0.226^{* * *} \\
(0.107)\end{array}$ & $\begin{array}{l}-0.040 \\
(0.125)\end{array}$ & $\begin{array}{l}-0.166 \\
(0.151)\end{array}$ & $\begin{array}{l}-0.398^{*} \\
(0.204)\end{array}$ & $\begin{array}{c}-0.533 * * \\
(0.250)\end{array}$ & $\begin{array}{c}-0.871 * * \\
(0.347)\end{array}$ \\
\hline ATE-AIPW Mining & $\begin{array}{c}-0.278 * * * * \\
(0.081)\end{array}$ & $\begin{array}{c}-0.234^{* * *} \\
(0.113)\end{array}$ & $\begin{array}{c}-0.394 * * * * \\
(0.144)\end{array}$ & $\begin{array}{c}-0.647 * * * \\
(0.212)\end{array}$ & $\begin{array}{c}-1.140 * * * \\
(0.354)\end{array}$ & $\begin{array}{c}-1.881 * * * * \\
(0.522)\end{array}$ \\
\hline ATE-AIPW Manufacturing & $\begin{array}{c}-1.576^{* * * * *} \\
(0.326)\end{array}$ & $\begin{array}{c}-2.831 * * * * \\
(0.495)\end{array}$ & $\begin{array}{c}-2.971 * * * \\
(0.641)\end{array}$ & $\begin{array}{c}-2.405 * * * \\
(0.839)\end{array}$ & $\begin{array}{c}-2.544 * * \\
(1.224)\end{array}$ & $\begin{array}{c}-4.279 * * * * \\
(1.642)\end{array}$ \\
\hline ATE-AIPW Services & $\begin{array}{c}-0.566^{* * * * *} \\
(0.150)\end{array}$ & $\begin{array}{c}-0.789^{* * * *} \\
(0.162) \\
\end{array}$ & $\begin{array}{c}-1.034 * * * * \\
(0.241) \\
\end{array}$ & $\begin{array}{c}-1.062 * * * \\
(0.289) \\
\end{array}$ & $\begin{array}{c}-1.498 * * * \\
(0.370) \\
\end{array}$ & $\begin{array}{c}-1.959 * * * * \\
(0.438)\end{array}$ \\
\hline Observations & 409 & 409 & 409 & 409 & 409 & 409 \\
\hline \# of Crises & 31 & 31 & 31 & 31 & 31 & 31 \\
\hline \# of Countries & 39 & 39 & 39 & 39 & 39 & 39 \\
\hline P-value Total Exports= Total Imports & 0.002 & 0.003 & 0.012 & 0.119 & 0.837 & 0.342 \\
\hline \multicolumn{7}{|l|}{ Panel C': Currency Crises } \\
\hline ATE-AIPW Total & $\begin{array}{c}-4.687 * * * * \\
(0.650)\end{array}$ & $\begin{array}{c}-5.187 * * * \\
(0.789)\end{array}$ & $\begin{array}{c}-5.589 * * * \\
(1.123)\end{array}$ & $\begin{array}{c}-5.694 * * * \\
(1.474)\end{array}$ & $\begin{array}{c}-5.854 * * * * \\
(1.874)\end{array}$ & $\begin{array}{c}-7.014 * * * * \\
(2.376)\end{array}$ \\
\hline ATE-AIPW Agriculture & $\begin{array}{c}-0.549 * * * * \\
(0.125)\end{array}$ & $\begin{array}{c}-0.318^{* * * *} \\
(0.115)\end{array}$ & $\begin{array}{c}-0.358^{* * *} \\
(0.141)\end{array}$ & $\begin{array}{c}-0.441 * * * * \\
(0.158)\end{array}$ & $\begin{array}{l}-0.202 \\
(0.172)\end{array}$ & $\begin{array}{c}-0.174 \\
(0.198)\end{array}$ \\
\hline ATE-AIPW Mining & $\begin{array}{c}-0.888^{* * * * *} \\
(0.136)\end{array}$ & $\begin{array}{c}-0.445 * * * * \\
(0.157)\end{array}$ & $\begin{array}{c}-1.317 * * * * \\
(0.270)\end{array}$ & $\begin{array}{c}-1.256 * * * \\
(0.296)\end{array}$ & $\begin{array}{c}-1.780 * * * * \\
(0.380)\end{array}$ & $\begin{array}{c}-2.058 * * * * \\
(0.449)\end{array}$ \\
\hline ATE-AIPW Manufacturing & $\begin{array}{c}-2.608 * * * * * \\
(0.413)\end{array}$ & $\begin{array}{c}-3.841 * * * * \\
(0.529)\end{array}$ & $\begin{array}{c}-3.345 * * * * \\
(0.701)\end{array}$ & $\begin{array}{c}-3.483 * * * \\
(0.951)\end{array}$ & $\begin{array}{c}-3.557 * * * * \\
(1.224)\end{array}$ & $\begin{array}{c}-4.313 * * * * \\
(1.555)\end{array}$ \\
\hline ATE-AIPW Services & $\begin{array}{c}-0.642^{* * * *} \\
(0.124)\end{array}$ & $\begin{array}{l}-0.582 * * * \\
(0.171)\end{array}$ & $\begin{array}{l}-0.569 * * \\
(0.245)\end{array}$ & $\begin{array}{l}-0.514^{*} \\
(0.301)\end{array}$ & $\begin{array}{l}-0.314 \\
(0.359)\end{array}$ & $\begin{array}{l}-0.469 \\
(0.442)\end{array}$ \\
\hline Observations & 409 & 409 & 409 & 409 & 409 & 409 \\
\hline \# of Crises & 33 & 33 & 33 & 33 & 33 & 33 \\
\hline \# of Countries & 39 & 39 & 39 & 39 & 39 & 39 \\
\hline P-value Total E & 0.000 & 0.000 & 0.000 & 0.000 & 0.086 & 0.869 \\
\hline
\end{tabular}

and total exports and imports relative to the year prior to the onset of the crisis for years 1-5 after the onset of the crisis, scaled pre-crisis GDP. Accumulated costs over five years. Observations in the treated and control groups are weighted by the propensity scores predicted in the treatment model. Maximum weights truncated at 10. 
Table D.11: Robustness, Maximum weight set to 20, Cumulative trade losses over five years after financial crises

\begin{tabular}{|c|c|c|c|c|c|c|}
\hline \multicolumn{7}{|c|}{ Panel I: Exports (\% of pre-crisis GDP) } \\
\hline & (1) & (2) & (3) & (4) & (5) & (6) \\
\hline & $h=0$ & $\mathrm{~h}=1$ & $h=2$ & $h=3$ & $h=4$ & $h=5$ \\
\hline \multicolumn{7}{|l|}{ Panel A: Debt Crises } \\
\hline ATE-AIPW Total & $\begin{array}{l}-0.080 \\
(0.548)\end{array}$ & $\begin{array}{c}-3.186 * * * \\
(0.646)\end{array}$ & $\begin{array}{c}-2.749 * * * \\
(0.849)\end{array}$ & $\begin{array}{c}-4.965 * * * \\
(1.291)\end{array}$ & $\begin{array}{c}-5.193 * * * \\
(1.693)\end{array}$ & $\begin{array}{l}-4.224^{*} \\
(2.526)\end{array}$ \\
\hline ATE-AIPW Agriculture & $\begin{array}{c}-0.239 \\
(0.220)\end{array}$ & $\begin{array}{c}0.069 \\
(0.244)\end{array}$ & $\begin{array}{l}0.595^{* * *} \\
(0.301)\end{array}$ & $\begin{array}{c}0.730 \\
(0.504)\end{array}$ & $\begin{array}{l}1.240^{*} \\
(0.706)\end{array}$ & $\begin{array}{c}2.661 * * \\
(1.181)\end{array}$ \\
\hline ATE-AIPW Mining & $\begin{array}{c}1.544^{* * * *} \\
(0.362)\end{array}$ & $\begin{array}{l}-0.291 \\
(0.370)\end{array}$ & $\begin{array}{c}0.188 \\
(0.401)\end{array}$ & $\begin{array}{c}-0.361 \\
(0.548)\end{array}$ & $\begin{array}{c}0.203 \\
(0.686)\end{array}$ & $\begin{array}{l}1.851^{*} \\
(1.003)\end{array}$ \\
\hline ATE-AIPW Manufacturing & $\begin{array}{c}-0.837 \text { ****** } \\
(0.186)\end{array}$ & $\begin{array}{c}-2.029 * * * * \\
(0.308)\end{array}$ & $\begin{array}{c}-2.474 * * * * \\
(0.413)\end{array}$ & $\begin{array}{c}-3.849 \text { **** } \\
(0.539)\end{array}$ & $\begin{array}{c}-4.870 * * * * \\
(0.731)\end{array}$ & $\begin{array}{c}-5.933 * * * * \\
(1.128)\end{array}$ \\
\hline ATE-AIPW Services & $\begin{array}{c}-0.547^{* * * * *} \\
(0.103)\end{array}$ & $\begin{array}{c}-0.936 * * * * \\
(0.155)\end{array}$ & $\begin{array}{c}-1.057 * * * * \\
(0.249)\end{array}$ & $\begin{array}{c}-1.485^{* * * * *} \\
(0.326)\end{array}$ & $\begin{array}{c}-1.766 * * * * \\
(0.358)\end{array}$ & $\begin{array}{c}-2.803 * * * * \\
(0.483)\end{array}$ \\
\hline Observations & 732 & 732 & 732 & 732 & 732 & 732 \\
\hline \# of Crises & 38 & 38 & 38 & 38 & 38 & 38 \\
\hline \# of Countries & 41 & 41 & 41 & 41 & 41 & 41 \\
\hline P-value Total Exports= Total Imports & 0.000 & 0.000 & 0.000 & 0.021 & 0.015 & 0.029 \\
\hline \multicolumn{7}{|l|}{ Panel B: Banking Crises } \\
\hline ATE-AIPW Total & $\begin{array}{c}-1.507 * * * * \\
(0.432)\end{array}$ & $\begin{array}{c}-5.105 * * * * \\
(0.658)\end{array}$ & $\begin{array}{c}-5.351 * * * * \\
(0.723)\end{array}$ & $\begin{array}{c}-5.129 * * * * \\
(0.934)\end{array}$ & $\begin{array}{c}-7.698^{* * * * *} \\
(1.229)\end{array}$ & $\begin{array}{c}-7.614 * * * * \\
(1.429)\end{array}$ \\
\hline ATE-AIPW Agriculture & $\begin{array}{l}-0.131 \\
(0.092)\end{array}$ & $\begin{array}{c}-0.407 * * * * \\
(0.130)\end{array}$ & $\begin{array}{c}-0.639 * * * * \\
(0.184)\end{array}$ & $\begin{array}{c}-0.811^{* * * * *} \\
(0.207)\end{array}$ & $\begin{array}{c}-1.004 * * * * \\
(0.259)\end{array}$ & $\begin{array}{c}-1.383 * * * * \\
(0.286)\end{array}$ \\
\hline ATE-AIPW Mining & $\begin{array}{c}-0.259 \\
(0.232)\end{array}$ & $\begin{array}{c}-1.041^{* * * *} \\
(0.276)\end{array}$ & $\begin{array}{c}-0.919 * * * * \\
(0.320)\end{array}$ & $\begin{array}{c}-1.153^{* * * *} \\
(0.404)\end{array}$ & $\begin{array}{c}-2.258 * * * * \\
(0.433)\end{array}$ & $\begin{array}{c}-1.252^{*} \\
(0.658)\end{array}$ \\
\hline ATE-AIPW Manufacturing & $\begin{array}{l}-0.347 * \\
(0.193)\end{array}$ & $\begin{array}{c}-1.664 * * * * \\
(0.439)\end{array}$ & $\begin{array}{c}-1.508 * * * * \\
(0.528)\end{array}$ & $\begin{array}{c}-0.948 \\
(0.646)\end{array}$ & $\begin{array}{l}-1.470^{*} \\
(0.802)\end{array}$ & $\begin{array}{l}-1.559 \\
(0.997)\end{array}$ \\
\hline ATE-AIPW Services & $\begin{array}{c}-0.769^{* * * *} \\
(0.148)\end{array}$ & $\begin{array}{c}-1.994 * * * * \\
(0.248)\end{array}$ & $\begin{array}{c}-2.285 * * * * \\
(0.342)\end{array}$ & $\begin{array}{c}-2.217 * * * * \\
(0.466)\end{array}$ & $\begin{array}{c}-2.967 * * * * \\
(0.545)\end{array}$ & $\begin{array}{c}-3.419^{* * *} \\
(0.684)\end{array}$ \\
\hline Observations & 732 & 732 & 732 & 732 & 732 & 732 \\
\hline & 34 & 34 & 34 & 34 & 34 & 34 \\
\hline & 41 & 41 & 41 & 41 & 41 & 41 \\
\hline P-value Total Exports= Total Imports & 0.000 & 0.000 & 0.000 & 0.000 & 0.000 & 0.000 \\
\hline \multicolumn{7}{|l|}{ Panel C: Currency Crises } \\
\hline ATE-AIPW Total & $\begin{array}{c}-4.289^{* * * * *} \\
(0.497)\end{array}$ & $\begin{array}{c}-3.923 * * * * \\
(0.620)\end{array}$ & $\begin{array}{c}-4.340 * * * * \\
(0.918)\end{array}$ & $\begin{array}{c}-4.417 * * * * \\
(1.114)\end{array}$ & $\begin{array}{c}-6.314^{* * * * *} \\
(1.285)\end{array}$ & $\begin{array}{c}-7.098 * * * * \\
(1.619)\end{array}$ \\
\hline ATE-AIPW Agriculture & $\begin{array}{c}0.042 \\
(0.113)\end{array}$ & $\begin{array}{l}-0.127 \\
(0.211)\end{array}$ & $\begin{array}{c}0.011 \\
(0.422)\end{array}$ & $\begin{array}{l}-0.037 \\
(0.454)\end{array}$ & $\begin{array}{c}0.120 \\
(0.396)\end{array}$ & $\begin{array}{c}0.451 \\
(0.550)\end{array}$ \\
\hline ATE-AIPW Mining & $\begin{array}{c}-0.867 * * * * * * \\
(0.249)\end{array}$ & $\begin{array}{c}-1.007 * * * * * \\
(0.252)\end{array}$ & $\begin{array}{c}-1.485 * * * * \\
(0.405)\end{array}$ & $\begin{array}{c}-1.407 * * * * * \\
(0.408)\end{array}$ & $\begin{array}{c}-2.445 * * * * \\
(0.442)\end{array}$ & $\begin{array}{c}-2.810^{* * * *} \\
(0.548)\end{array}$ \\
\hline ATE-AIPW Manufacturing & $\begin{array}{c}-2.511 * * * * \\
(0.296)\end{array}$ & $\begin{array}{c}-2.195 * * * * \\
(0.351)\end{array}$ & $\begin{array}{c}-2.434 * * * * \\
(0.401)\end{array}$ & $\begin{array}{c}-2.924 * * * * * \\
(0.565)\end{array}$ & $\begin{array}{c}-3.789 * * * * \\
(0.675)\end{array}$ & $\begin{array}{c}-4.206 * * * * \\
(0.807)\end{array}$ \\
\hline \multirow[t]{2}{*}{ ATE-AIPW Services } & $-0.954 * * *$ & $-0.594 * * *$ & -0.433 & -0.049 & -0.200 & -0.533 \\
\hline & $(0.120)$ & $(0.217)$ & $(0.286)$ & $(0.423)$ & $(0.505)$ & $(0.590)$ \\
\hline Observa & 732 & 732 & 732 & 732 & 732 & 732 \\
\hline \# of Crises & 36 & 36 & 36 & 36 & 36 & 36 \\
\hline \# of Countries & 41 & 41 & 41 & 41 & 41 & 41 \\
\hline P-value Total Exports= Total Imports & 0.000 & 0.000 & 0.000 & 0.000 & 0.001 & 0.452 \\
\hline
\end{tabular}

\begin{tabular}{|c|c|c|c|c|c|c|}
\hline \multicolumn{7}{|c|}{ Panel II: Imports (\% of pre-crisis GDP) } \\
\hline & (1) & (2) & (3) & (4) & (5) & (6) \\
\hline & $h=0$ & $h=1$ & $h=2$ & $h=3$ & $h=4$ & $\mathrm{~h}=5$ \\
\hline \multicolumn{7}{|l|}{ Panel A': Debt Crises } \\
\hline ATE-AIPW Total & $\begin{array}{c}-3.748^{* * * * *} \\
(0.760)\end{array}$ & $\begin{array}{c}-8.087 * * * * \\
(0.935)\end{array}$ & $\begin{array}{c}-7.590^{* * * * *} \\
(1.596)\end{array}$ & $\begin{array}{c}-8.127 * * * \\
(2.012)\end{array}$ & $\begin{array}{c}-8.633 * * * * \\
(2.515)\end{array}$ & $\begin{array}{c}-8.839 * * \\
(3.475)\end{array}$ \\
\hline ATE-AIPW Agriculture & $\begin{array}{c}-0.352^{* * * * *} \\
(0.117)\end{array}$ & $\begin{array}{c}-0.783^{* * * *} \\
(0.118)\end{array}$ & $\begin{array}{c}-0.594 * * \\
(0.233)\end{array}$ & $\begin{array}{c}-0.896 * * * \\
(0.218)\end{array}$ & $\begin{array}{c}-1.113 * * * * \\
(0.271)\end{array}$ & $\begin{array}{c}-0.845 * * \\
(0.333)\end{array}$ \\
\hline ATE-AIPW Mining & $\begin{array}{c}-0.622^{* * * * *} \\
(0.126)\end{array}$ & $\begin{array}{c}-1.464 * * * * \\
(0.239)\end{array}$ & $\begin{array}{c}-1.491 * * * * \\
(0.334)\end{array}$ & $\begin{array}{c}-1.850 * * * * \\
(0.468)\end{array}$ & $\begin{array}{c}-1.648 * * * * \\
(0.590)\end{array}$ & $\begin{array}{c}-1.656 * * \\
(0.842)\end{array}$ \\
\hline ATE-AIPW Manufacturing & $\begin{array}{c}-1.834^{* * * * *} \\
(0.492)\end{array}$ & $\begin{array}{c}-4.289^{* * * *} * \\
(0.595)\end{array}$ & $\begin{array}{c}-3.342 * * * * \\
(0.968)\end{array}$ & $\begin{array}{c}-3.281 * * * * \\
(1.231)\end{array}$ & $\begin{array}{c}-3.542 * * \\
(1.573)\end{array}$ & $\begin{array}{l}-4.011^{*} \\
(2.202)\end{array}$ \\
\hline ATE-AIPW Services & $\begin{array}{c}-0.939^{* * * * *} \\
(0.188)\end{array}$ & $\begin{array}{c}-1.551^{* * * *} \\
(0.238)\end{array}$ & $\begin{array}{c}-2.164 * * * * \\
(0.332)\end{array}$ & $\begin{array}{c}-2.099 * * * * \\
(0.353)\end{array}$ & $\begin{array}{c}-2.330 * * * * \\
(0.427)\end{array}$ & $\begin{array}{c}-2.327 * * * * \\
(0.501)\end{array}$ \\
\hline & 732 & 732 & 732 & 732 & 732 & 732 \\
\hline & 38 & 38 & 38 & 38 & 38 & 38 \\
\hline
\end{tabular}

\begin{tabular}{lcccccc} 
\# of Countries & 41 & 41 & 41 & 41 & 41 & 41 \\
P-value Total Exports= Total Imports & 0.000 & 0.000 & 0.000 & 0.021 & 0.015 & 0.029 \\
\hline
\end{tabular}

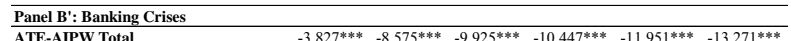

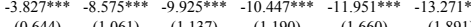

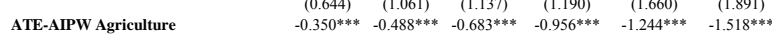

$\begin{array}{lllllll} & (0.115) & (0.149) & (0.170) & (0.159) & (0.193) & (0.192) \\ \text { ATE-AIPW Mining } & -0.802 * * * & -1.425 * * * & -1.742 * * * & -2.041 * * * & -2.414 * * * & -2.775 * * *\end{array}$

$-(0.139)-(0.193)-(0.209)-(0.253)-(0.318)-(0.361)$

$\begin{array}{lllllll}\text { ATE-AIPW Manufacturing } \quad-2.142 * * * & -5.332 * * * & -5.675 * * * & -5.466 * * * & -5.927 * * * & -6.406 * * *\end{array}$

\begin{tabular}{lcccccc} 
& $(0.372)$ & $(0.685)$ & $(0.722)$ & $(0.768)$ & $(1.084)$ & $(1.280)$ \\
ATE-AIPW Services & $-0.533 * * *$ & $-1.331 * * *$ & $-1.825 * * *$ & $-1.983 * *$ & $-2.365 * * *$ & $-2.572 * * *$ \\
\hline
\end{tabular}

\begin{tabular}{lcccccc} 
& $(0.152)$ & $(0.166)$ & $(0.252)$ & $(0.281)$ & $(0.328)$ & $(0.369)$ \\
\hline Observations & 732 & 732 & 732 & 732 & 732 & 732
\end{tabular}

Observations

\# of Countries

$\begin{array}{lcc}732 & 732 \\ 34 & 34 & 34\end{array}$

\begin{tabular}{lcccccc} 
& 41 & 41 & 41 & 41 & 41 & 41 \\
P-value Total Exports= Total Imports & 0.000 & 0.000 & 0.000 & 0.000 & 0.000 & 0.000 \\
\hline
\end{tabular}

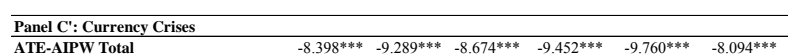
\begin{tabular}{lcccccc}
\hline ATE-AIPW Total & $-8.398^{* * * *}$ & $-9.289^{* * * *}$ & $-8.674^{* * *}$ & $-9.452^{* * *}$ & $-9.760 * * *$ & $-8.094 * * *$ \\
& $(0.790)$ & $(0.903)$ & $(1.243)$ & $(1.544)$ & $(1.869)$ & $(2.475)$
\end{tabular} $\begin{array}{lllllll}\text { ATE-AIPW Agriculture } & -0.684 * * * & -0.693 * * * & -0.744 * * * & -0.976 * * * & -0.730 * * * & -0.502 * *\end{array}$

$\begin{array}{lcccccc} & (0.145) & (0.117) & (0.156) & (0.162) & (0.202) & (0.256) \\ \text { ATE-AIPW Mining } & -1.751 * * * & -1.403 * * * & -1.668 * * * & -1.866 * * * & -2.679 * * * & -2.593 * * *\end{array}$

$\begin{array}{lllllll} & (0.157) & (0.206) & (0.308) & (0.366) & (0.385) & (0.606)\end{array}$

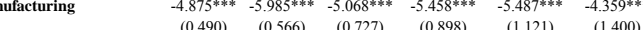

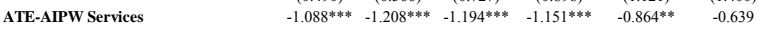

\begin{tabular}{lcccccc} 
& $(0.116)$ & $(0.182)$ & $(0.257)$ & $(0.330)$ & $(0.387)$ & $(0.430)$ \\
\hline Observations & 732 & 732 & 732 & 732 & 732 & 732
\end{tabular}

Observation
\# of Crises

$\begin{array}{lcccc}\text { \# of Crises } & 36 & 36 & 36 & 36 \\ \text { \# of Countries } & 41 & 41 & 41 & 4 \\ \text { P-value Total Exports= Total Imports } & 0.000 & 0.000 & 0.000 & 0.000\end{array}$ and total exports and imports relative to the year prior to the onset of the crisis for years 1-5 after the onset of the crisis, scaled pre-crisis GDP. Accumulated costs over five years. Observations in the treated and control groups are weighted by the propensity scores predicted in the treatment model. Maximum weights truncated at 10 
Table D.13: Robustness, Alternative sources and definitions of crises, Cumulative trade losses over five years after financial crises

\begin{tabular}{|c|c|c|c|c|c|c|c|c|c|c|c|c|c|}
\hline \multicolumn{7}{|c|}{ 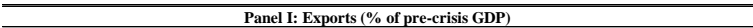 } & \multicolumn{7}{|c|}{ Panel II: Imports (\% of pre-crisis GDP) } \\
\hline & (1) & (2) & (3) & (4) & (5) & (6) & & (1) & (2) & (3) & (4) & (5) & (6) \\
\hline & $\mathbf{h = 0}$ & $h=1$ & $h=2$ & $\mathrm{~h}=3$ & $h=4$ & $\mathrm{~h}=5$ & & $\mathbf{h = 0}$ & $h=1$ & $h=2$ & $\mathrm{~h}=3$ & $\mathrm{~h}=4$ & $\mathrm{~h}=5$ \\
\hline \multicolumn{7}{|l|}{ Panel A: Debt Crises } & \multicolumn{7}{|l|}{ Panel A': Debt Crises } \\
\hline ATE-AIPW Total & $\begin{array}{c}-1.408^{* * * * *} \\
(0.384)\end{array}$ & $\begin{array}{c}-2.015^{* * * * *} \\
(0.551)\end{array}$ & $\begin{array}{c}-3.179 * * * \\
(0.769)\end{array}$ & $\begin{array}{c}-4.189^{* * * *} \\
(1.102)\end{array}$ & $\begin{array}{c}-5.069 * * * \\
(1.256)\end{array}$ & $\begin{array}{c}-5.063 * * * \\
(1.611)\end{array}$ & ATE-AIPW Total & $\begin{array}{c}-3.102 * * * \\
(0.464)\end{array}$ & $\begin{array}{c}-5.427 * * * \\
(0.702)\end{array}$ & $\begin{array}{c}-5.799 * * * \\
(1.044)\end{array}$ & $\begin{array}{c}-4.693 * * * \\
(1.385)\end{array}$ & $\begin{array}{l}-4.553 * * * \\
(1.582)\end{array}$ & $\begin{array}{l}-2.668 \\
(1806\end{array}$ \\
\hline ATE-AIPW Agriculture & $\begin{array}{c}(0.504) \\
0.151 \\
(0.115)\end{array}$ & $\begin{array}{c}0.212 \\
(0.160)\end{array}$ & $\begin{array}{c}0.574 * * * \\
(0.216)\end{array}$ & $\begin{array}{c}0.401 \\
(0.338)\end{array}$ & $\begin{array}{c}0.466 \\
(0.353)\end{array}$ & $\begin{array}{l}1.195 * * * * \\
(0.432)\end{array}$ & ATE-AIPW Agriculture & $\begin{array}{c}-0.4046^{* * * *} \\
(0.078)\end{array}$ & $\begin{array}{c}-0.422^{* * *} \\
(0.092)\end{array}$ & $\begin{array}{c}-0.429 * * * \\
(0.112)\end{array}$ & $\begin{array}{l}-0.318^{*} \\
(0.191)\end{array}$ & $\begin{array}{c}-0.359 * * \\
(0.161)\end{array}$ & $\begin{array}{l}-0.191 \\
-0.184)\end{array}$ \\
\hline ATE-AIPW Mining & $\begin{array}{c}-0.589^{* * *} \\
(0.239)\end{array}$ & $\begin{array}{c}-0.961 * * * * \\
(0.251)\end{array}$ & $\begin{array}{c}-1.262 * * * \\
(0.349)\end{array}$ & $\begin{array}{c}-1.445^{* * * *} \\
(0.481)\end{array}$ & $\begin{array}{c}-1.474 * * * * \\
(0.518)\end{array}$ & $\begin{array}{c}-1.393 * * \\
(0.672)\end{array}$ & ATE-AIPW Mining & $\begin{array}{c}-0.296 * * * * \\
(0.084)\end{array}$ & $\begin{array}{c}-0.614 * * * \\
(0.128)\end{array}$ & $\begin{array}{c}-0.905 * * * * \\
(0.198)\end{array}$ & $\begin{array}{c}-1.289 * * * \\
(0.259)\end{array}$ & $\begin{array}{c}-1.556 * * * * \\
(0.303)\end{array}$ & $\begin{array}{c}-1.478 * * * * \\
(0.471)\end{array}$ \\
\hline ATE-AIPW Manufacturing & $-0.743 * * *$ & $\begin{array}{l}-1.010^{* * * *} \\
(0269)\end{array}$ & $\begin{array}{l}-2.167 * * * \\
(0.367 *\end{array}$ & $\begin{array}{l}-2.953 * * * * \\
(0.493 *\end{array}$ & $\begin{array}{l}-3.993 * * * \\
0.633 *\end{array}$ & $\begin{array}{l}-4.949 * * * \\
0.786\end{array}$ & ATE-AIPW Manufacturing & $\begin{array}{l}-1.642 * * * \\
(0305 *\end{array}$ & $\begin{array}{l}-3.224 * * * \\
(0.461\end{array}$ & $\begin{array}{l}-3.412 * * * \\
0.663 *\end{array}$ & $\begin{array}{l}-2.116 * * \\
(0878)\end{array}$ & $\begin{array}{l}-1.952^{*} \\
0\end{array}$ & $\begin{array}{l}-0.854 \\
-1059\end{array}$ \\
\hline ATE-AIPW Services & $\begin{array}{c}-0.227 * * * * \\
(0.082)\end{array}$ & $\begin{array}{l}-0.257^{*} \\
(0.133)\end{array}$ & $\begin{array}{c}-0.325 \\
(0.199)\end{array}$ & $\begin{array}{c}-0.192 \\
(0.240)\end{array}$ & $\begin{array}{c}-0.068 \\
(0.312)\end{array}$ & $\begin{array}{c}0.084 \\
(0.398)\end{array}$ & ATE-AIPW Services & $\begin{array}{c}-0.878^{* * * *} \\
(0.111)\end{array}$ & $\begin{array}{c}-1.168 * * * \\
(0.163)\end{array}$ & $\begin{array}{c}-1.053 * * * * \\
(0.230)\end{array}$ & $\begin{array}{c}-0.970^{* * *} \\
(0.249)\end{array}$ & $\begin{array}{c}-0.686^{* *} \\
(0.288)\end{array}$ & $\begin{array}{c}-0.145 \\
(0.315)\end{array}$ \\
\hline Observations & 5900 & 590 & 590 & $\frac{5000}{590}$ & 590 & $\frac{(0.590)}{590}$ & Observations & $\frac{(1.11)}{590}$ & 590 & 590 & 590 & 590 & $\frac{5.3117}{590}$ \\
\hline \# of Crises & 41 & 41 & 41 & 41 & 41 & 41 & \# of Crises & 41 & 41 & 41 & 41 & 41 & 41 \\
\hline \# of Countries & 31 & 31 & 31 & 31 & 31 & 31 & $\#$ of Countries & 31 & 31 & 31 & 31 & 31 & 31 \\
\hline P-value Total Exports= Total Imports & 0.000 & 0.000 & 0.001 & 0.552 & 0.559 & 0.014 & P-value Total Exports= Total Imports & 0.000 & 0.000 & 0.001 & 0.552 & 0.559 & 0.014 \\
\hline \multicolumn{7}{|l|}{ Panel B: Banking Crises } & \multicolumn{7}{|l|}{ Panel B': Banking Crises } \\
\hline ATE-AIPW Total & $\begin{array}{c}-1.525 * * * * \\
(0.340)\end{array}$ & $\begin{array}{c}-4.126^{* * * *} \\
(0.474)\end{array}$ & $\begin{array}{c}-5.473 * * * \\
(0.589)\end{array}$ & $\begin{array}{c}-6.291 * * * * \\
(0.789)\end{array}$ & $\begin{array}{c}-8.058^{* * * * *} \\
(1.044)\end{array}$ & $\begin{array}{c}-8.470 * * * * \\
(1.252)\end{array}$ & ATE-AIPW Total & $\begin{array}{c}-3.179 * * * \\
(0.529)\end{array}$ & $\begin{array}{c}-6.036 * * * \\
(0.761)\end{array}$ & $\begin{array}{c}-7.383 * * * * \\
(0.952)\end{array}$ & $\begin{array}{c}-8.324 * * * \\
(1.048)\end{array}$ & $\begin{array}{c}-8.729 * * * \\
(1.325)\end{array}$ & $\begin{array}{c}-10.438 * * * * \\
(1.577)\end{array}$ \\
\hline ATE-AIPW Agriculture & $\begin{array}{c}-0.117 \\
(0.093)\end{array}$ & $\begin{array}{c}-0.196 \\
(0.131)\end{array}$ & $\begin{array}{l}-0.325^{*} \\
(0.195)\end{array}$ & $\begin{array}{c}-0.349 \\
(0.219)\end{array}$ & $\begin{array}{c}-0.574 * * \\
(0.257)\end{array}$ & $\begin{array}{c}-0.300 \\
(0.354)\end{array}$ & ATE-AIPW Agriculture & $\begin{array}{c}-0.331 \text { **** } \\
(0.113)\end{array}$ & $\begin{array}{c}-0.446 * * * \\
(0.118)\end{array}$ & $\begin{array}{c}-0.464 * * * * \\
(0.133)\end{array}$ & $\begin{array}{c}-0.699 * * * \\
(0.139)\end{array}$ & $\begin{array}{c}-0.670^{* * * *} \\
(0.139)\end{array}$ & $\begin{array}{c}-0.908 * * * * \\
(0.160)\end{array}$ \\
\hline ATE-AIPW Mining & $\begin{array}{c}-0.414^{* * * * *} \\
(0.156)\end{array}$ & $\begin{array}{c}-1.211^{* * * *} \\
(0.221)\end{array}$ & $\begin{array}{c}-1.476 * * * * \\
(0.267)\end{array}$ & $\begin{array}{c}-1.760 * * * * \\
(0.341)\end{array}$ & $\begin{array}{c}-2.339 * * * \\
(0.414)\end{array}$ & $\begin{array}{c}-1.938 * * * * \\
(0.551)\end{array}$ & ATE-AIPW Mining & $\begin{array}{c}-0.350^{* * * * *} \\
(0.086)\end{array}$ & $\begin{array}{c}-0.596 * * * * \\
(0.132)\end{array}$ & $\begin{array}{c}-0.951 * * * * \\
(0.157)\end{array}$ & $\begin{array}{c}-1.367 * * * \\
(0.178)\end{array}$ & $\begin{array}{c}-1.670 * * * * \\
(0.235)\end{array}$ & $\begin{array}{c}-1.883 * * * * \\
(0.290)\end{array}$ \\
\hline ATE-AIPW Manufacturing & $\begin{array}{c}-0.659^{* * * * *} \\
(0.209)\end{array}$ & $\begin{array}{c}-1.733^{* * * *} \\
(0.303)\end{array}$ & $\begin{array}{c}-2.339 * * * \\
(0.408)\end{array}$ & $\begin{array}{c}-2.712 * * * \\
(0.555)\end{array}$ & $\begin{array}{c}-3.316 * * * \\
(0.706)\end{array}$ & $\begin{array}{c}-4.311 * * * * \\
(0.836)\end{array}$ & ATE-AIPW Manufacturing & $\begin{array}{c}-2.153 * * * \\
(0.338)\end{array}$ & $\begin{array}{c}-4.167 * * * \\
(0.516)\end{array}$ & $\begin{array}{c}-4.845 * * * * \\
(0.639)\end{array}$ & $\begin{array}{c}-5.182 * * * \\
(0.717)\end{array}$ & $\begin{array}{c}-4.906 * * * * \\
(0.925)\end{array}$ & $\begin{array}{c}-5.760 * * * * \\
(1.114)\end{array}$ \\
\hline ATE-AIPW Services & $\begin{array}{c}-0.335^{* * * * *} \\
(0.102)\end{array}$ & $\begin{array}{c}-0.986^{* * * *} \\
(0.168)\end{array}$ & $\begin{array}{c}-1.333 * * * \\
(0.220)\end{array}$ & $\begin{array}{c}-1.470^{* * * *} \\
(0.264)\end{array}$ & $\begin{array}{c}-1.830 * * * \\
(0.336)\end{array}$ & $\begin{array}{c}-1.922 * * * * \\
(0.392)\end{array}$ & ATE-AIPW Services & $\begin{array}{c}-0.345^{* * * *} \\
(0.095)\end{array}$ & $\begin{array}{c}-0.827 * * * \\
(0.114)\end{array}$ & $\begin{array}{c}-1.123 * * * * \\
(0.180)\end{array}$ & $\begin{array}{c}-1.075 * * * \\
(0.205)\end{array}$ & $\begin{array}{c}-1.483 * * * * \\
(0.229)\end{array}$ & $\begin{array}{c}-1.887 * * * \\
(0.263)\end{array}$ \\
\hline Observations & 590 & 590 & 590 & 590 & 590 & 590 & Observations & 590 & 590 & 590 & 590 & 590 & 590 \\
\hline \# of Crises & 44 & 44 & 44 & 44 & 44 & 44 & \# of Crises & 44 & 44 & 44 & 44 & 44 & 44 \\
\hline \# of Countries & 31 & 31 & 31 & 31 & 31 & 31 & \# of Countries & 31 & 31 & 31 & 31 & 31 & 31 \\
\hline P-value Total Exports= Total Imports & 0.001 & 0.001 & 0.006 & 0.004 & 0.379 & 0.063 & P-value Total Exports= Total Imports & 0.001 & 0.001 & 0.006 & 0.004 & 0.379 & 0.063 \\
\hline \multicolumn{7}{|l|}{ Panel C: Currency Crises } & \multicolumn{7}{|l|}{ Panel C': Currency Crises } \\
\hline ATE-AIPW Total & $\begin{array}{c}-0.609 \\
(0.462)\end{array}$ & $\begin{array}{c}-3.360^{* * * * *} \\
(0.656)\end{array}$ & $\begin{array}{c}-4.102 * * * \\
(0.727)\end{array}$ & $\begin{array}{c}-3.490^{* * * * *} \\
(0.945)\end{array}$ & $\begin{array}{c}-4.686^{* * * *} \\
(1.332)\end{array}$ & $\begin{array}{c}-5.157 * * * \\
(1.739)\end{array}$ & ATE-AIPW Total & $\begin{array}{c}-0.548 \\
(0.512)\end{array}$ & $\begin{array}{c}-5.051 * * * \\
(0.762)\end{array}$ & $\begin{array}{c}-5.245^{* * * *} \\
(0.958)\end{array}$ & $\begin{array}{c}-3.995 * * * \\
(1.163)\end{array}$ & $\begin{array}{c}-5.357 * * * \\
(1.473)\end{array}$ & $\begin{array}{c}-4.713 * * \\
(2.081)\end{array}$ \\
\hline ATE-AIPW Agriculture & $\begin{array}{c}0.003 \\
(0.168)\end{array}$ & $\begin{array}{l}-0.317^{*} \\
(0.175)\end{array}$ & $\begin{array}{c}-0.475 * * * \\
(0.182)\end{array}$ & $\begin{array}{c}-0.507 * * \\
(0.222)\end{array}$ & $\begin{array}{c}-0.616 * * * \\
(0.229)\end{array}$ & $\begin{array}{c}-0.584 * * \\
(0.296)\end{array}$ & ATE-AIPW Agriculture & $\begin{array}{c}-0.092 \\
(0.060)\end{array}$ & $\begin{array}{c}-0.484 * * * \\
(0.083)\end{array}$ & $\begin{array}{c}-0.508^{* * * *} \\
(0.108)\end{array}$ & $\begin{array}{c}-0.408 * * * \\
(0.140)\end{array}$ & $\begin{array}{c}-0.653 * * * * \\
(0.156)\end{array}$ & $\begin{array}{c}-0.475 * * \\
(0.207)\end{array}$ \\
\hline ATE-AIPW Mining & $\begin{array}{c}-0.394 \\
(0.248)\end{array}$ & $\begin{array}{c}-1.075 * * * \\
(0.275)\end{array}$ & $\begin{array}{c}-1.147 * * * \\
(0.348)\end{array}$ & $\begin{array}{c}-1.115^{* * * * *} \\
(0.407)\end{array}$ & $\begin{array}{c}-1.933 * * * * \\
(0.478)\end{array}$ & $\begin{array}{c}-2.186 * * * \\
(0.577)\end{array}$ & ATE-AIPW Mining & $\begin{array}{l}0.028 \\
0.124)\end{array}$ & $\begin{array}{l}-0.861 * * * \\
(0.149)\end{array}$ & $\begin{array}{l}-0.953 * * * \\
(0.175)\end{array}$ & $\begin{array}{c}-0.968 * * * \\
(0.217)\end{array}$ & $\begin{array}{c}-1.219 * * * \\
(0.258)\end{array}$ & $\begin{array}{c}-1.239 * * * \\
(0.361)\end{array}$ \\
\hline ATE-AIPW Manufacturing & $\begin{array}{c}0.075 \\
(0.220)\end{array}$ & $\begin{array}{c}-0.994 * * * \\
(0.383)\end{array}$ & $\begin{array}{c}-1.309 * * * \\
(0.473)\end{array}$ & $\begin{array}{c}-0.894 \\
(0.656)\end{array}$ & $\begin{array}{l}-1.150 \\
(0.934)\end{array}$ & $\begin{array}{c}-0.984 \\
(1.262)\end{array}$ & ATE-AIPW Manufacturing & $\begin{array}{c}-0.424 \\
(0.331)\end{array}$ & $\begin{array}{c}-3.112 * * * \\
(0.533)\end{array}$ & $\begin{array}{c}-2.973 * * * * \\
(0.668)\end{array}$ & $\begin{array}{c}-1.941 * * \\
(0.823)\end{array}$ & $\begin{array}{c}-2.783 * * * \\
(1.023)\end{array}$ & $\begin{array}{l}-2.315^{*} \\
(1.398)\end{array}$ \\
\hline ATE-AIPW Services & $\begin{array}{c}-0.294^{* * *} \\
(0.121)\end{array}$ & $\begin{array}{c}-0.974 * * * \\
(0.194)\end{array}$ & $\begin{array}{c}-1.171 * * * \\
(0.245)\end{array}$ & $\begin{array}{c}-0.975 * * * * \\
(0.318)\end{array}$ & $\begin{array}{c}-0.988^{* *} \\
(0.432)\end{array}$ & $\begin{array}{c}-1.403 * * * \\
(0.462)\end{array}$ & ATE-AIPW Services & $\begin{array}{c}-0.059 \\
(0.111)\end{array}$ & $\begin{array}{c}-0.594 * * * \\
(0.129)\end{array}$ & $\begin{array}{c}-0.811 * * * * \\
(0.181)\end{array}$ & $\begin{array}{c}-0.679 * * * \\
(0.218)\end{array}$ & $\begin{array}{c}-0.702 * * \\
(0.291)\end{array}$ & $\begin{array}{l}-0.684^{*} \\
(0.370)\end{array}$ \\
\hline Observations & 590 & 590 & 590 & 590 & 590 & 590 & Observations & 590 & 590 & 590 & 590 & 590 & 590 \\
\hline \# of Crises & 69 & 69 & 69 & 69 & 69 & 69 & \# of Crises & 69 & 69 & 69 & 69 & 69 & 69 \\
\hline \# of Countries & 31 & 31 & 31 & 31 & 31 & 31 & \# of Countries & 31 & 31 & 31 & 31 & 31 & 31 \\
\hline P-value Total Exports= Total Imports & 0.898 & 0.004 & 0.154 & 0.590 & 0.557 & 0.715 & P-value Total Exports= Total Imports & 0.898 & 0.004 & 0.154 & 0.590 & 0.557 & 0.715 \\
\hline
\end{tabular}


Table D.14: Robustness, Inverse Probability Weighted (IPW) estimator, Cumulative trade losses over five years after financial crises

\begin{tabular}{|c|c|c|c|c|c|c|c|c|c|c|c|c|c|}
\hline \multicolumn{7}{|c|}{ Panel I: Exports (\% of pre-crisis GDP) } & \multicolumn{7}{|c|}{ Panel II: Imports (\% of pre-crisis GDP) } \\
\hline & (1) & (2) & (3) & (4) & (5) & (6) & & (1) & (2) & (3) & (4) & (5) & (6) \\
\hline & $h=0$ & $h=1$ & $h=2$ & $h=3$ & $h=4$ & $\mathrm{~h}=5$ & & $h=0$ & $\mathrm{~h}=\mathbf{1}$ & $h=2$ & $h=3$ & $h=4$ & $h=5$ \\
\hline \multicolumn{7}{|l|}{ Panel A: Debt Crises } & \multicolumn{7}{|l|}{ Panel A': Debt Crises } \\
\hline ATE-IPW Total & $\begin{array}{c}-1.217^{* * * * *} \\
(0.284)\end{array}$ & $\begin{array}{c}2.667 * * * \\
(0.898)\end{array}$ & $\begin{array}{c}-3.576 * * * \\
(1.112)\end{array}$ & $\begin{array}{c}-5.509 * * * * \\
(1.164)\end{array}$ & $\begin{array}{c}-5.567^{* * * *} \\
(1.066)\end{array}$ & $\begin{array}{c}-4.068 * * * \\
(0.850)\end{array}$ & ATE-IPW Total & $\begin{array}{c}-5.012^{* * * *} \\
(0.838)\end{array}$ & $\begin{array}{c}-5.826 * * * \\
(1.027)\end{array}$ & $\begin{array}{c}-6.225 * * * \\
(1.407)\end{array}$ & $\begin{array}{c}-7.082 * * * \\
(2.219)\end{array}$ & $\begin{array}{c}-5.982 * * * \\
(1.460)\end{array}$ & $\begin{array}{c}-3.581 * * * * \\
(0.280)\end{array}$ \\
\hline ATE-IPW Agriculture & $\begin{array}{c}-0.246 \\
(0.300)\end{array}$ & $\begin{array}{c}0.134 \\
(0.241)\end{array}$ & $\begin{array}{c}0.488^{* * * *} \\
(0.186)\end{array}$ & $\begin{array}{c}0.940 * * * \\
(0.224)\end{array}$ & $\begin{array}{l}1.325 * * \\
(0.549)\end{array}$ & $\begin{array}{l}2.702^{*} \\
(1.387)\end{array}$ & ATE-IPW Agriculture & $\begin{array}{c}-0.405^{* * * *} \\
(0.096)\end{array}$ & $\begin{array}{c}-0.588 * * * \\
(0.167)\end{array}$ & $\begin{array}{c}-0.795 * * * \\
(0.228)\end{array}$ & $\begin{array}{c}-1.074 * * * \\
(0.318)\end{array}$ & $\begin{array}{c}-0.823 * * \\
(0.327)\end{array}$ & $\begin{array}{c}-0.396 * * * * \\
(0.067)\end{array}$ \\
\hline ATE-IPW Mining & $\begin{array}{l}0.474^{*} \\
(0.253)\end{array}$ & $\begin{array}{c}-0.029 \\
(0.493)\end{array}$ & $\begin{array}{c}-0.252 \\
(0.380)\end{array}$ & $\begin{array}{c}-1.069^{* * * *} \\
(0.256)\end{array}$ & $\begin{array}{c}-0.461 \\
(0.398)\end{array}$ & $\begin{array}{c}0.602 \\
(0.702)\end{array}$ & ATE-IPW Mining & $\begin{array}{c}-0.501 * * \\
(0.199)\end{array}$ & $\begin{array}{c}-0.733 * * * \\
(0.253)\end{array}$ & $\begin{array}{c}-1.183 * * * * \\
(0.333)\end{array}$ & $\begin{array}{c}-1.607 * * * \\
(0.282)\end{array}$ & $\begin{array}{c}-1.472 * * * * \\
(0.335)\end{array}$ & $\begin{array}{c}-0.441^{* * * *} \\
(0.099)\end{array}$ \\
\hline ATE-IPW Manufacturing & $\begin{array}{c}-0.793 * * * * \\
(0.235)\end{array}$ & $\begin{array}{c}-1.551^{* * * *} \\
(0.358)\end{array}$ & $\begin{array}{c}-2.414 * * * * \\
(0.555)\end{array}$ & $\begin{array}{c}-3.646 * * * * * \\
(0.675)\end{array}$ & $\begin{array}{c}-4.360^{* * * *} \\
(0.921)\end{array}$ & $\begin{array}{c}-4.986 * * * * \\
(1.067)\end{array}$ & ATE-IPW Manufacturing & $\begin{array}{c}-3.042 * * * * \\
(0.520)\end{array}$ & $\begin{array}{c}-3.047 * * * * \\
(0.624)\end{array}$ & $\begin{array}{c}-2.735 * * * \\
(0.747)\end{array}$ & $\begin{array}{c}-2.826 * * * \\
(1.120)\end{array}$ & $\begin{array}{c}-2.125 * * \\
(0.903)\end{array}$ & $\begin{array}{c}-1.960 * * * * \\
(0.209)\end{array}$ \\
\hline ATE-IPW Services & $\begin{array}{c}-0.652^{* * * * *} \\
(0.142)\end{array}$ & $\begin{array}{c}-1.221^{* * * *} \\
(0.302)\end{array}$ & $\begin{array}{c}-1.398 * * * \\
(0.368)\end{array}$ & $\begin{array}{c}-1.735^{* * * * *} \\
(0.595)\end{array}$ & $\begin{array}{c}-2.071 * * * * \\
(0.740)\end{array}$ & $\begin{array}{c}-2.387 * * * \\
(0.780)\end{array}$ & ATE-IPW Services & $\begin{array}{c}-1.064^{* * * *} \\
(0.241)\end{array}$ & $\begin{array}{c}-1.458^{* * *} \\
(0.254)\end{array}$ & $\begin{array}{c}-1.512 * * * \\
(0.474)\end{array}$ & $\begin{array}{c}-1.574 * * \\
(0.658)\end{array}$ & $\begin{array}{c}-1.562 * * \\
(0.631)\end{array}$ & $\begin{array}{c}-0.784 * * * * \\
(0.082)\end{array}$ \\
\hline Observations & 732 & 732 & 732 & 732 & 732 & 732 & Observations & 732 & 732 & 732 & 732 & 732 & 732 \\
\hline \# of Crises & 38 & 38 & 38 & 38 & 38 & 38 & \# of Crises & 38 & 38 & 38 & 38 & 38 & 38 \\
\hline \# of Countries & 41 & 41 & 41 & 41 & 41 & 41 & \# of Countries & 41 & 41 & 41 & 41 & 41 & 41 \\
\hline P-value Total Exports= Total Imports & 0.027 & 0.053 & 0.119 & 0.690 & 0.361 & 0.434 & P-value Total Exports= Total Imports & 0.053 & 0.119 & 0.690 & 0.361 & 0.434 & 0.027 \\
\hline \multicolumn{7}{|l|}{ Panel B: Banking Crises } & \multicolumn{7}{|l|}{ Panel B': Banking Crises } \\
\hline ATE-IPW Total & $\begin{array}{c}-1.344^{* * * * *} \\
(0.440)\end{array}$ & $\begin{array}{c}-5.400^{* * * * *} \\
(1.868)\end{array}$ & $\begin{array}{c}-5.681 * * * \\
(1.819)\end{array}$ & $\begin{array}{c}5.263 * * * * \\
(1.843)\end{array}$ & $\begin{array}{c}-7.923 * * * * \\
(2.405)\end{array}$ & $\begin{array}{c}-7.786 * * * \\
(2.647)\end{array}$ & ATE-IPW Total & $\begin{array}{c}-9.309 * * * * \\
(2.975)\end{array}$ & $\begin{array}{c}-10.412^{* * * * *} \\
(3.369)\end{array}$ & $\begin{array}{c}-10.230^{* * * *} \\
(3.722)\end{array}$ & $\begin{array}{c}-11.879 * * * * \\
(4.541)\end{array}$ & $\begin{array}{c}-12.939 * * * * \\
(4.912)\end{array}$ & $\begin{array}{c}-3.315 * * * * \\
(0.525)\end{array}$ \\
\hline ATE-IPW Agriculture & $\begin{array}{c}-0.119^{* * *} \\
(0.060)\end{array}$ & $\begin{array}{c}-0.530^{* * * *} \\
(0.178)\end{array}$ & $\begin{array}{c}-0.722 * * * \\
(0.215)\end{array}$ & $\begin{array}{c}-0.819^{* * * * *} \\
(0.206)\end{array}$ & $\begin{array}{c}-0.961 * * * * \\
(0.279)\end{array}$ & $\begin{array}{c}-1.304 * * * * \\
(0.276)\end{array}$ & ATE-IPW Agriculture & $\begin{array}{c}-0.521^{* * *} \\
(0.244)\end{array}$ & $\begin{array}{c}-0.655 * * \\
(0.302)\end{array}$ & $\begin{array}{c}-0.869 * * \\
(0.349)\end{array}$ & $\begin{array}{c}-1.149 * * \\
(0.453)\end{array}$ & $\begin{array}{c}-1.354 * * * * \\
(0.502)\end{array}$ & $\begin{array}{c}-0.361 * * * \\
(0.070)\end{array}$ \\
\hline ATE-IPW Mining & $\begin{array}{c}-0.282^{* * *} \\
(0.127)\end{array}$ & $\begin{array}{c}-1.073^{*} \\
(0.550)\end{array}$ & $\begin{array}{c}-0.964^{*} \\
(0.551)\end{array}$ & $\begin{array}{c}-1.213^{* *} \\
(0.514)\end{array}$ & $\begin{array}{c}-2.262 * * * * \\
(0.635)\end{array}$ & $\begin{array}{c}-1.447^{*} \\
(0.835)\end{array}$ & ATE-IPW Mining & $\begin{array}{c}-1.611 * * * * \\
(0.582)\end{array}$ & $\begin{array}{c}-1.832^{* * * *} \\
(0.577)\end{array}$ & $\begin{array}{c}-1.920 * * * \\
(0.584)\end{array}$ & $\begin{array}{c}-2.354 * * * \\
(0.722)\end{array}$ & $\begin{array}{c}-2.779^{* * * *} \\
(0.873)\end{array}$ & $\begin{array}{c}-0.669 * * * * \\
(0.121)\end{array}$ \\
\hline ATE-IPW Manufacturing & $\begin{array}{c}-0.198 \\
(0.236)\end{array}$ & $\begin{array}{c}-1.767 * * \\
(0.835)\end{array}$ & $\begin{array}{c}-1.639 * * \\
(0.640)\end{array}$ & $\begin{array}{l}-1.012^{*} \\
(0.599)\end{array}$ & $\begin{array}{c}-1.711 * * \\
(0.867)\end{array}$ & $\begin{array}{c}-1.713^{*} \\
(0.888)\end{array}$ & ATE-IPW Manufacturing & $\begin{array}{c}-5.798^{* * * *} \\
(1.842)\end{array}$ & $\begin{array}{c}-5.978 * * * \\
(2.001)\end{array}$ & $\begin{array}{l}-5.402 * * \\
(2.153)\end{array}$ & $\begin{array}{l}-5.924 * * \\
(2.629)\end{array}$ & $\begin{array}{c}-6.206 * * \\
(2.775)\end{array}$ & $\begin{array}{c}-1.868 * * * \\
(0.315)\end{array}$ \\
\hline ATE-IPW Services & $\begin{array}{c}-0.745^{* * * * *} \\
(0.105)\end{array}$ & $\begin{array}{c}-2.031^{* * * * *} \\
(0.352)\end{array}$ & $\begin{array}{c}-2.357 * * * * \\
(0.483)\end{array}$ & $\begin{array}{c}-2.219^{* * * * *} \\
(0.637)\end{array}$ & $\begin{array}{c}-2.989 * * * \\
(0.762)\end{array}$ & $\begin{array}{c}-3.321 * * * \\
(0.794)\end{array}$ & ATE-IPW Services & $\begin{array}{c}-1.379 * * * \\
(0.329)\end{array}$ & $\begin{array}{c}-1.947 * * * \\
(0.512)\end{array}$ & $\begin{array}{c}-2.040^{* * * *} \\
(0.659)\end{array}$ & $\begin{array}{c}-2.452 * * * \\
(0.763)\end{array}$ & $\begin{array}{c}-2.600 * * * * \\
(0.795)\end{array}$ & $\begin{array}{c}-0.416 * * * * \\
(0.130)\end{array}$ \\
\hline Observations & 732 & 732 & 732 & 732 & 732 & 732 & Observations & 732 & 732 & 732 & 732 & 732 & 732 \\
\hline \# of Crises & 34 & 34 & 34 & 34 & 34 & 34 & \# of Crises & 34 & 34 & 34 & 34 & 34 & 34 \\
\hline \# of Countries & 41 & 41 & 41 & 41 & 41 & 41 & \# of Countries & 41 & 41 & 41 & 41 & 41 & 41 \\
\hline P-value Total Exports= Total Imports & 0.024 & 0.000 & 0.000 & 0.000 & 0.003 & 0.002 & P-value Total Exports= Total Imports & 0.000 & 0.000 & 0.000 & 0.003 & 0.002 & 0.024 \\
\hline Panel C: Currency Crises & & & & & & & Panel C': Currency Crises & & & & & & \\
\hline ATE-IPW Total & $\begin{array}{c}-2.687^{*} \\
(1.387)\end{array}$ & $\begin{array}{c}-3.601 * * * \\
(1.256)\end{array}$ & $\begin{array}{c}-4.047 * * * \\
(1.254)\end{array}$ & $\begin{array}{c}-4.871 * * * * \\
(1.526)\end{array}$ & $\begin{array}{c}-6.220^{* * * *} \\
(1.600)\end{array}$ & $\begin{array}{c}-6.749^{* * * *} \\
(1.248)\end{array}$ & ATE-IPW Total & $\begin{array}{c}-7.923 * * * * \\
(2.038)\end{array}$ & $\begin{array}{c}-8.230^{* * *} \\
(2.072)\end{array}$ & $\begin{array}{c}-8.786^{* * *} \\
(2.678)\end{array}$ & $\begin{array}{c}-9.370^{* * *} \\
(3.115)\end{array}$ & $\begin{array}{c}-8.338^{* * * *} \\
(2.305)\end{array}$ & $\begin{array}{c}-6.451 * * * * \\
(1.924)\end{array}$ \\
\hline ATE-IPW Agriculture & $\begin{array}{c}0.106 \\
(0.174)\end{array}$ & $\begin{array}{l}-0.176 \\
(0.157)\end{array}$ & $\begin{array}{c}0.279 \\
(0.313)\end{array}$ & $\begin{array}{c}0.106 \\
(0.193)\end{array}$ & $\begin{array}{c}0.136 \\
(0.192)\end{array}$ & $\begin{array}{l}0.550^{*} \\
(0.282)\end{array}$ & ATE-IPW Agriculture & $\begin{array}{c}-0.644^{* * * *} \\
(0.192)\end{array}$ & $\begin{array}{c}-0.749^{* * * *} \\
(0.240)\end{array}$ & $\begin{array}{c}-0.857 * * * \\
(0.304)\end{array}$ & $\begin{array}{c}-0.736 * * \\
(0.336)\end{array}$ & $\begin{array}{c}-0.634 * * \\
(0.293)\end{array}$ & $\begin{array}{c}-0.584 * * * * \\
(0.144)\end{array}$ \\
\hline ATE-IPW Mining & $\begin{array}{c}-0.487 \\
(0.297)\end{array}$ & $\begin{array}{c}-1.046^{* * * * *} \\
(0.297)\end{array}$ & $\begin{array}{c}-1.449 * * * * \\
(0.318)\end{array}$ & $\begin{array}{c}-1.775^{* * * *} \\
(0.418)\end{array}$ & $\begin{array}{c}-2.481 * * * * \\
(0.424)\end{array}$ & $\begin{array}{c}-2.447 * * * \\
(0.366)\end{array}$ & ATE-IPW Mining & $\begin{array}{c}-1.415^{* * * *} \\
(0.372)\end{array}$ & $\begin{array}{c}-1.839 * * * \\
(0.324)\end{array}$ & $\begin{array}{c}-2.158 * * * \\
(0.377)\end{array}$ & $\begin{array}{c}-2.620 * * * \\
(0.503)\end{array}$ & $\begin{array}{c}-2.063 * * * * \\
(0.376)\end{array}$ & $\begin{array}{c}-1.210^{* * * *} \\
(0.356)\end{array}$ \\
\hline ATE-IPW Manufacturing & $\begin{array}{c}-1.427 * * \\
(0.705)\end{array}$ & $\begin{array}{c}-1.872 * * * \\
(0.577)\end{array}$ & $\begin{array}{c}-2.436 * * * \\
(0.429)\end{array}$ & $\begin{array}{c}-2.911 * * * * \\
(0.542)\end{array}$ & $\begin{array}{c}-3.557 * * * * \\
(0.686)\end{array}$ & $\begin{array}{c}-3.922 * * * \\
(0.560)\end{array}$ & ATE-IPW Manufacturing & $\begin{array}{c}-4.759 * * * * \\
(1.209)\end{array}$ & $\begin{array}{c}-4.541 * * * \\
(1.278)\end{array}$ & $\begin{array}{c}-4.631 * * * \\
(1.580)\end{array}$ & $\begin{array}{c}-5.008 * * * \\
(1.800)\end{array}$ & $\begin{array}{c}-4.520 * * * * \\
(1.326)\end{array}$ & $\begin{array}{c}-3.723 * * * * \\
(1.197)\end{array}$ \\
\hline ATE-IPW Services & $-0.879 * * *$ & -0.506 & -0.440 & -0.292 & -0.318 & $-0.931^{*}$ & ATE-IPW Services & $-1.105 * * *$ & $-1.100^{* * *}$ & $-1.139 * *$ & $-1.005^{*}$ & $-1.121 * *$ & $-0.934 * * *$ \\
\hline & $(0.242)$ & $(0.309)$ & $(0.451)$ & $(0.575)$ & $(0.531)$ & $(0.505)$ & & $(0.300)$ & $(0.366)$ & $(0.505)$ & $(0.533)$ & $(0.521)$ & $(0.253)$ \\
\hline Observations & 732 & 732 & 732 & 732 & 732 & 732 & Observations & 732 & 732 & 732 & 732 & 732 & 732 \\
\hline \# of Crises & 36 & 36 & 36 & 36 & 36 & 36 & \# of Crises & 36 & 36 & 36 & 36 & 36 & 36 \\
\hline \# of Countries & 41 & 41 & 41 & 41 & 41 & 41 & \# of Countries & 41 & 41 & 41 & 41 & 41 & 41 \\
\hline P-value Total Exports= Total Imports & 0.000 & 0.000 & 0.004 & 0.004 & 0.028 & 0.376 & P-value Total Exports= Total Imports & 0.000 & 0.004 & 0.004 & 0.028 & 0.376 & 0.000 \\
\hline
\end{tabular}




\section{B.3. Channels}

Table A.15a: Channels, Cumulative trade losses over five years after debt crises with higher and lower manufacturing exports

\begin{tabular}{|c|c|c|c|c|c|c|c|c|c|c|c|c|c|}
\hline \multicolumn{7}{|c|}{ Panel I: Exports (\% of pre-crisis GDP) } & \multicolumn{7}{|c|}{ Panel II: Imports (\% of pre-crisis GDP) } \\
\hline & (1) & (2) & (3) & (4) & (5) & (6) & & (1) & (2) & (3) & (4) & (5) & (6) \\
\hline & $h=0$ & $\mathrm{~h}=1$ & $\mathrm{~h}=\mathbf{2}$ & $h=3$ & $h=4$ & $h=5$ & & $\mathbf{h}=\mathbf{0}$ & $h=1$ & $\mathrm{~h}=\mathbf{2}$ & $h=3$ & $h=4$ & $h=5$ \\
\hline \multicolumn{7}{|c|}{ Panel A: Debt crises } & \multicolumn{7}{|c|}{ Panel A: Debt crises } \\
\hline Panel a: Total & & & & & & & Panel a: Total & & & & & & \\
\hline ATE-AIPW High & $\begin{array}{c}-1.621^{* * * *} \\
(0.300)\end{array}$ & $\begin{array}{c}-1.750^{* * * *} \\
(0.480)\end{array}$ & $\begin{array}{c}-2.203 * * * \\
(0.620)\end{array}$ & $\begin{array}{c}* 3.785^{* * *} \\
(0.812)\end{array}$ & $\begin{array}{c}-4.775 * * * \\
(1.002)\end{array}$ & $\begin{array}{c}-3.693^{* * *} \\
(1.285)\end{array}$ & ATE-AIPW High & $\begin{array}{c}-2.023^{* * *} \\
(0.505)\end{array}$ & $\begin{array}{c}-3.473^{* * *} \\
(0.641)\end{array}$ & $\begin{array}{c}-3.523 * * * \\
(0.937)\end{array}$ & $\begin{array}{c}-3.911 * * * \\
(1.123)\end{array}$ & $\begin{array}{c}-4.280^{* * * *} \\
(1.399)\end{array}$ & $\begin{array}{c}-3.274^{* * *} \\
(1.633)\end{array}$ \\
\hline ATE-AIPW Low & $\begin{array}{l}-0.649^{*} \\
(0.336)\end{array}$ & $\begin{array}{c}-3.375 * * * \\
(0.455)\end{array}$ & $\begin{array}{c}-4.900^{* * *} \\
(0.620)\end{array}$ & $\begin{array}{c}*-7.863 * * * \\
(0.873)\end{array}$ & $\begin{array}{c}-7.811 * * * \\
(1.091)\end{array}$ & $\begin{array}{c}-7.610^{* * *} \\
(1.437)\end{array}$ & ATE-AIPW Low & $\begin{array}{c}-3.935 * * * \\
(0.540)\end{array}$ & $\begin{array}{c}-6.851 * * * \\
(0.692)\end{array}$ & $\begin{array}{c}-7.775 * * * \\
(1.014)\end{array}$ & $\begin{array}{c}-9.486^{* * *} \\
(1.225)\end{array}$ & $\begin{array}{c}-10.617^{* * *} \\
(1.539)\end{array}$ & $\begin{array}{c}-10.384^{* * *} \\
(2.014)\end{array}$ \\
\hline P-value High=Low & 0.000 & 0.000 & 0.000 & 0.000 & 0.000 & 0.000 & P-value High=Low & 0.000 & 0.000 & 0.000 & 0.000 & 0.000 & 0.000 \\
\hline Avg.(trade) in countries above cutoff & 3.030 & 6.212 & 9.802 & 13.553 & 17.101 & 21.167 & Avg.(trade) in countries above cutoff & 3.678 & 7.557 & 11.744 & 16.187 & 20.486 & 25.232 \\
\hline Avg.(trade) in countries below cutoff & 2.844 & 5.659 & 8.548 & 11.798 & 14.526 & 17.317 & Avg.(trade) in countries below cutoff & 3.305 & 6.505 & 9.622 & 13.326 & 17.041 & 20.623 \\
\hline \multicolumn{7}{|l|}{ Panel b: Agriculture } & Panel b: Agriculture & & & & & & \\
\hline ATE-AIPW High & $\begin{array}{c}-0.645^{* * *} \\
(0.111)\end{array}$ & $\begin{array}{l}-0.090 \\
(0.112)\end{array}$ & $\begin{array}{l}-0.103 \\
(0.156)\end{array}$ & $\begin{array}{c}0.229 \\
(0.210)\end{array}$ & $\begin{array}{c}0.246 \\
(0.237)\end{array}$ & $\begin{array}{c}1.188^{* * *} \\
(0.278)\end{array}$ & ATE-AIPW High & $\begin{array}{c}0.009 \\
(0.096)\end{array}$ & $\begin{array}{c}-0.310^{* * *} \\
(0.088)\end{array}$ & $\begin{array}{c}-0.376^{* * *} \\
(0.135)\end{array}$ & $\begin{array}{c}-0.494 * * * \\
(0.133)\end{array}$ & $\begin{array}{c}-0.593^{* * * *} \\
(0.159)\end{array}$ & $\begin{array}{c}-0.349^{* *} \\
(0.174)\end{array}$ \\
\hline ATE-AIPW Low & $\begin{array}{c}0.075 \\
(0.102) \\
\end{array}$ & $\begin{array}{c}0.081 \\
(0.134) \\
\end{array}$ & $\begin{array}{l}0.354^{*} \\
(0.181)\end{array}$ & $\begin{array}{l}0.553^{* *} \\
(0.281)\end{array}$ & $\begin{array}{l}0.756^{*} \\
(0.393)\end{array}$ & $\begin{array}{c}1.901 * * * \\
(0.631) \\
\end{array}$ & ATE-AIPW Low & $\begin{array}{c}-0.293 * * * \\
(0.101)\end{array}$ & $\begin{array}{c}-0.688^{* * *} \\
(0.088)\end{array}$ & $\begin{array}{c}-0.742 * * * \\
(0.138) \\
\end{array}$ & $\begin{array}{c}-1.099^{* * *} \\
(0.133) \\
\end{array}$ & $\begin{array}{c}-1.434 * * * \\
(0.160)\end{array}$ & $\begin{array}{c}-1.226 * * * \\
(0.182) \\
\end{array}$ \\
\hline P-value High=Low & 0.000 & 0.181 & 0.003 & 0.230 & 0.166 & 0.252 & P-value High=Low & 0.000 & 0.000 & 0.000 & 0.000 & 0.000 & 0.000 \\
\hline Avg.(trade) in countries above cutoff & 0.368 & 0.728 & 1.160 & 1.597 & 2.034 & 2.546 & Avg.(trade) in countries above cutoff & 0.330 & 0.691 & 1.072 & 1.495 & 1.928 & 2.415 \\
\hline Avg.(trade) in countries below cutoff & 0.422 & 0.937 & 1.471 & 2.103 & 2.536 & 3.161 & Avg.(trade) in countries below cutoff & 0.329 & 0.634 & 0.951 & 1.325 & 1.653 & 1.951 \\
\hline \multicolumn{7}{|l|}{ Panel c: Mining } & Panel c: Mining & & & & & & \\
\hline ATE-AIPW High & $\begin{array}{c}-0.232^{*} \\
(0.127)\end{array}$ & $\begin{array}{l}-0.212 \\
(0.195)\end{array}$ & $\begin{array}{l}-0.397 \\
(0.247)\end{array}$ & $\begin{array}{l}-0.598^{*} \\
(0.321)\end{array}$ & $\begin{array}{l}-0.683^{*} \\
(0.401)\end{array}$ & $\begin{array}{l}-0.598 \\
(0.483)\end{array}$ & ATE-AIPW High & $\begin{array}{c}-0.683^{* * *} \\
(0.087)\end{array}$ & $\begin{array}{c}-0.599^{* * *} \\
(0.149)\end{array}$ & $\begin{array}{c}-0.713 * * * \\
(0.194)\end{array}$ & $\begin{array}{c}-1.283^{* * *} \\
(0.269)\end{array}$ & $\begin{array}{c}-0.552^{*} \\
(0.329)\end{array}$ & $\begin{array}{l}-0.276 \\
(0.423)\end{array}$ \\
\hline ATE-AIPW Low & $\begin{array}{c}0.646^{* * *} \\
(0.210)\end{array}$ & $\begin{array}{c}0.228 \\
(0.242)\end{array}$ & $\begin{array}{l}-0.232 \\
(0.276)\end{array}$ & $\begin{array}{c}-1.717 * * * \\
(0.365)\end{array}$ & $\begin{array}{l}-0.713^{*} \\
(0.426)\end{array}$ & $\begin{array}{c}0.338 \\
(0.591)\end{array}$ & ATE-AIPW Low & $\begin{array}{c}-0.175^{* *} \\
(0.088)\end{array}$ & $\begin{array}{c}-0.558^{* * *} \\
(0.170) \\
\end{array}$ & $\begin{array}{c}-0.871 * * * \\
(0.213) \\
\end{array}$ & $\begin{array}{c}-1.519 * * * \\
(0.268)\end{array}$ & $\begin{array}{c}-2.261^{* * * *} \\
(0.326) \\
\end{array}$ & $\begin{array}{c}-2.406 * * * \\
(0.430) \\
\end{array}$ \\
\hline P-value High=Low & 0.000 & 0.018 & 0.305 & 0.000 & 0.915 & 0.036 & $\overline{P \text {-value High=Low }}$ & 0.000 & 0.750 & 0.268 & 0.230 & 0.000 & 0.000 \\
\hline Avg.(trade) in countries above cutoff & 0.341 & 0.761 & 1.246 & 1.756 & 2.230 & 2.730 & Avg.(trade) in countries above cutoff & 0.642 & 1.346 & 2.126 & 2.960 & 3.709 & 4.479 \\
\hline Avg.(trade) in countries below cutoff & 0.975 & 1.833 & 2.767 & 3.778 & 4.560 & 5.295 & Avg.(trade) in countries below cutoff & 0.444 & 0.902 & 1.356 & 1.839 & 2.191 & 2.551 \\
\hline \multicolumn{7}{|l|}{ Panel d: Manufacturing } & Panel d: Manufacturing & & & & & & \\
\hline ATE-AIPW High & $\begin{array}{c}-0.573 * * * \\
(0.147)\end{array}$ & $\begin{array}{c}-0.857 * * * \\
(0.262)\end{array}$ & $\begin{array}{c}-1.480^{* * *} \\
(0.319)\end{array}$ & $\begin{array}{c}-2.883^{* * *} \\
(0.409)\end{array}$ & $\begin{array}{c}-3.455 * * * \\
(0.514)\end{array}$ & $\begin{array}{c}-3.561^{* * *} \\
(0.670)\end{array}$ & ATE-AIPW High & $\begin{array}{c}-1.036^{* * *} \\
(0.317)\end{array}$ & $\begin{array}{c}-1.763^{* * *} \\
(0.405)\end{array}$ & $\begin{array}{c}-1.717^{* * *} \\
(0.573)\end{array}$ & $\begin{array}{c}-1.478^{* *} \\
(0.661)\end{array}$ & $\begin{array}{c}-2.384 * * * \\
(0.815)\end{array}$ & $\begin{array}{c}-2.205 * * \\
(0.921)\end{array}$ \\
\hline ATE-AIPW Low & $\begin{array}{c}-0.851^{* * *} \\
(0.136)\end{array}$ & $\begin{array}{c}-2.074^{* * * *} \\
(0.222)\end{array}$ & $\begin{array}{c}-2.963^{* * * *} \\
(0.308)\end{array}$ & $\begin{array}{c}-4.102^{* * * *} \\
(0.401)\end{array}$ & $\begin{array}{c}-5.047 * * * \\
(0.509)\end{array}$ & $\begin{array}{c}-5.975^{* * *} \\
(0.663)\end{array}$ & ATE-AIPW Low & $\begin{array}{c}-2.371^{* * * *} \\
(0.342)\end{array}$ & $\begin{array}{c}-4.014^{* * *} \\
(0.427)\end{array}$ & $\begin{array}{c}-3.951^{* * *} \\
(0.618)\end{array}$ & $\begin{array}{c}-4.481 * * * \\
(0.761)\end{array}$ & $\begin{array}{c}-4.544 * * * \\
(0.972)\end{array}$ & $\begin{array}{c}-3.966 * * * \\
(1.305)\end{array}$ \\
\hline P-value High=Low & 0.000 & 0.000 & 0.000 & 0.000 & 0.000 & 0.000 & P-value High=Low & 0.000 & 0.000 & 0.000 & 0.000 & 0.002 & 0.086 \\
\hline Avg.(trade) in countries above cutoff & 1.502 & 3.078 & 4.808 & 6.585 & 8.254 & 10.168 & Avg.(trade) in countries above cutoff & 2.093 & 4.242 & 6.542 & 8.920 & 11.275 & 13.933 \\
\hline Avg.(trade) in countries below cutoff & 0.648 & 1.295 & 1.865 & 2.645 & 3.324 & 4.003 & Avg.(trade) in countries below cutoff & 1.949 & 3.816 & 5.627 & 7.811 & 10.218 & 12.546 \\
\hline \multicolumn{7}{|l|}{ Panel e: Services } & Panel e: Services & & & & & & \\
\hline ATE-AIPW High & $\begin{array}{c}-0.171 * * \\
(0.084)\end{array}$ & $\begin{array}{c}-0.590^{* * * *} \\
(0.135)\end{array}$ & $\begin{array}{c}-0.223 \\
(0.195)\end{array}$ & $\begin{array}{c}-0.533^{* *} \\
(0.243)\end{array}$ & $\begin{array}{c}-0.882^{* * * *} \\
(0.291)\end{array}$ & $\begin{array}{c}-0.722 * * \\
(0.353)\end{array}$ & ATE-AIPW High & $\begin{array}{c}-0.312^{* * *} \\
(0.106)\end{array}$ & $\begin{array}{c}-0.802^{* * *} \\
(0.131)\end{array}$ & $\begin{array}{c}-0.717 * * * \\
(0.174)\end{array}$ & $\begin{array}{c}-0.655^{* * *} \\
(0.207)\end{array}$ & $\begin{array}{c}-0.751 * * * \\
(0.251)\end{array}$ & $\begin{array}{l}-0.444 \\
(0.298)\end{array}$ \\
\hline \multirow[t]{2}{*}{ ATE-AIPW Low } & $-0.520^{* * *}$ & $-1.610^{* * *}$ & $-2.060^{* * *}$ & $-2.597 * * *$ & $-2.807 * * *$ & $-3.874 * * *$ & ATE-AIPW Low & $-1.095^{* * *}$ & $-1.590 * * *$ & $-2.212 * * *$ & $-2.387^{* * *}$ & $-2.378^{* * *}$ & $-2.787^{* * *}$ \\
\hline & $(0.078)$ & $(0.132)$ & $(0.191)$ & $(0.244)$ & $(0.290)$ & $(0.349)$ & & $(0.113)$ & $(0.143)$ & $(0.200)$ & $(0.229)$ & $(0.271)$ & $(0.305)$ \\
\hline P-value High=Low & 0.000 & 0.000 & 0.000 & 0.000 & 0.000 & 0.000 & P-value High=Low & 0.000 & 0.000 & 0.000 & 0.000 & 0.000 & 0.000 \\
\hline Avg.(trade) in countries above cutoff & 0.819 & 1.645 & 2.587 & 3.614 & 4.583 & 5.723 & Avg.(trade) in countries above cutoff & 0.614 & 1.277 & 2.004 & 2.812 & 3.573 & 4.404 \\
\hline Avg.(trade) in countries below cutoff & 0.799 & 1.594 & 2.445 & 3.272 & 4.106 & 4.857 & Avg.(trade) in countries below cutoff & 0.582 & 1.154 & 1.688 & 2.349 & 2.980 & 3.576 \\
\hline Observations & 709 & 709 & 709 & 709 & 709 & 709 & Observations & 709 & 709 & 709 & 709 & 709 & 709 \\
\hline$\#$ of Crises & 20 & 20 & 20 & 20 & 20 & 20 & \# of Crises & 20 & 20 & 20 & 20 & 20 & 20 \\
\hline Cutoff of channel variable, median & 17.031 & 17.031 & 17.031 & 17.031 & 17.031 & 17.031 & Cutoff of channel variable, median & 17.031 & 17.031 & 17.031 & 17.031 & 17.031 & 17.031 \\
\hline
\end{tabular}

CInternational Monetary Fund. Not for Redistribution 
Table A.15b: Channels, Cumulative trade losses over five years after banking crises with higher and lower manufacturing exports

\begin{tabular}{|c|c|c|c|c|c|c|}
\hline \multicolumn{7}{|c|}{ Panel I: Exports (\% of pre-crisis GDP) } \\
\hline & (1) & (2) & (3) & (4) & (5) & (6) \\
\hline & $\mathrm{h}=\mathbf{0}$ & $\mathrm{h}=1$ & $\mathbf{h}=\mathbf{2}$ & $h=3$ & $h=4$ & $h=5$ \\
\hline \multicolumn{7}{|c|}{ Panel B: Banking crises } \\
\hline \multicolumn{7}{|l|}{ Panel a: Total } \\
\hline ATE-AIPW High & $\begin{array}{c}-0.693^{* *} \\
(0.303)\end{array}$ & $\begin{array}{c}-5.293 * * * \\
(0.492)\end{array}$ & $\begin{array}{c}-5.197 * * * \\
(0.592)\end{array}$ & $\begin{array}{c}*-3.396^{* * *} \\
(0.754)\end{array}$ & $\begin{array}{c}-5.414^{* * *} \\
(0.911)\end{array}$ & $\begin{array}{c}-5.917 * * * \\
(1.137)\end{array}$ \\
\hline \multirow[t]{2}{*}{ ATE-AIPW Low } & $-1.800^{* * *}$ & $-5.228 * * *$ & $-6.804 * * *$ & $*-9.202 * * *$ & $-12.355 * * *$ & $*-13.474 * * *$ \\
\hline & $(0.287)$ & $(0.475)$ & $(0.589)$ & $(0.739)$ & $(0.874)$ & $(1.071)$ \\
\hline P-value High=Low & 0.000 & 0.787 & 0.000 & 0.000 & 0.000 & 0.000 \\
\hline Avg.(trade) in countries above cutoff & 3.326 & 6.776 & 10.597 & 14.705 & 18.538 & 22.813 \\
\hline Avg.(trade) in countries below cutoff & 2.526 & 5.128 & 7.980 & 10.952 & 13.618 & 16.620 \\
\hline \multicolumn{7}{|l|}{ Panel b: Agriculture } \\
\hline ATE-AIPW High & $\begin{array}{l}-0.112^{*} \\
(0.059)\end{array}$ & $\begin{array}{c}-0.674^{* * * *} \\
(0.081)\end{array}$ & $\begin{array}{c}-1.013^{* * * *} \\
(0.103)\end{array}$ & $\begin{array}{c}* 1.100^{* * * *} \\
(0.137)\end{array}$ & $\begin{array}{c}-1.181^{* * *} \\
(0.161)\end{array}$ & $\begin{array}{c}-1.503^{* * * *} \\
(0.191)\end{array}$ \\
\hline \multirow[t]{2}{*}{ ATE-AIPW Low } & -0.063 & $-0.346^{* * *}$ & $-0.621 * * *$ & $*_{-}-0.790^{* * *}$ & $-1.073^{* * *}$ & $-1.563^{* * *}$ \\
\hline & $(0.064)$ & $(0.094)$ & $(0.136)$ & $(0.162)$ & $(0.183)$ & $(0.213)$ \\
\hline P-value High=Low & 0.352 & 0.000 & 0.000 & 0.007 & 0.409 & 0.653 \\
\hline Avg.(trade) in countries above cutoff & 0.346 & 0.705 & 1.100 & 1.511 & 1.928 & 2.389 \\
\hline Avg.(trade) in countries below cutoff & 0.431 & 0.887 & 1.432 & 2.024 & 2.485 & 3.133 \\
\hline \multicolumn{7}{|l|}{ Panel c: Mining } \\
\hline \multirow[t]{2}{*}{ ATE-AIPW High } & $-0.484 * * *$ & ${ }^{*}-1.281^{* * *}$ & $-1.619^{* * *}$ & $*-1.879^{* * *}$ & $-2.633^{* * *}$ & $-2.880^{* * *}$ \\
\hline & $(0.140)$ & $(0.226)$ & $(0.249)$ & $(0.271)$ & $(0.325)$ & $(0.410)$ \\
\hline \multirow[t]{2}{*}{ ATE-AIPW Low } & 0.136 & $-0.446^{*}$ & -0.132 & $-0.710^{* *}$ & $-1.676^{* * * *}$ & -0.521 \\
\hline & $(0.166)$ & $(0.238)$ & $(0.276)$ & $(0.311)$ & $(0.353)$ & $(0.482)$ \\
\hline $\begin{array}{l}\text { P-value High=Low } \\
\end{array}$ & 0.000 & 0.000 & 0.000 & 0.000 & 0.000 & 0.000 \\
\hline Avg.(trade) in countries above cutoff & 0.308 & 0.640 & 1.038 & 1.474 & 1.853 & 2.258 \\
\hline Avg.(trade) in countries below cutoff & 0.778 & 1.584 & 2.462 & 3.378 & 4.167 & 4.938 \\
\hline \multicolumn{7}{|l|}{ Panel d: Manufacturing } \\
\hline \multirow[t]{2}{*}{ ATE-AIPW High } & 0.241 & $-1.514 * * *$ & -0.538 & $1.225^{* *}$ & 0.731 & 1.014 \\
\hline & $(0.166)$ & $(0.293)$ & $(0.381)$ & $(0.484)$ & $(0.559)$ & $(0.693)$ \\
\hline \multirow[t]{2}{*}{ ATE-AIPW Low } & $-1.004 * * *$ & $*-2.437 * * *$ & $-3.557 * * *$ & $*-4.765^{* * * *}$ & $-5.660^{* * *}$ & $-6.751^{* * *}$ \\
\hline & $(0.126)$ & $(0.221)$ & $(0.308)$ & $(0.406)$ & $(0.484)$ & $(0.586)$ \\
\hline P-value High=Low & 0.000 & 0.000 & 0.000 & 0.000 & 0.000 & 0.000 \\
\hline Avg.(trade) in countries above cutoff & 1.779 & 3.641 & 5.676 & 7.799 & 9.775 & 11.987 \\
\hline Avg.(trade) in countries below cutoff & 0.609 & 1.235 & 1.845 & 2.552 & 3.203 & 3.961 \\
\hline \multicolumn{7}{|l|}{ Panel e: Services } \\
\hline ATE-AIPW High & $-0.338^{* * *}$ & $-1.824^{* * *}$ & $-2.027^{* * *}$ & * $-1.641^{* * * *}$ & $-2.331^{* * *}$ & $-2.549^{* * *}$ \\
\hline \multirow{2}{*}{ ATE-AIPW Low } & $\begin{array}{c}(0.096) \\
-0.868 * * *\end{array}$ & $\begin{aligned} & (0.166) \\
- & -1.999 * * *\end{aligned}$ & $=(0.242)$ & $\begin{aligned} & (0.322) \\
* & -2.937 * * *\end{aligned}$ & $\begin{array}{c}(0.394) \\
-3.946 * * *\end{array}$ & $\begin{array}{c}(0.515) \\
-4.639^{* * *}\end{array}$ \\
\hline & $(0.093)$ & $(0.142)$ & $(0.193)$ & $(0.259)$ & $(0.332)$ & $(0.416)$ \\
\hline P-value High=Low & 0.000 & 0.121 & 0.003 & 0.000 & 0.000 & 0.000 \\
\hline Avg.(trade) in countries above cutoff & 0.894 & 1.791 & 2.784 & 3.921 & 4.982 & 6.178 \\
\hline Avg.(trade) in countries below cutoff & 0.708 & 1.422 & 2.240 & 2.999 & 3.764 & 4.589 \\
\hline Observations & 711 & 711 & 711 & 711 & 711 & 711 \\
\hline \# of Crises & 19 & 19 & 19 & 19 & 19 & 19 \\
\hline Cutoff of channel variable, median & 27.083 & 27.083 & 27.083 & 27.083 & 27.083 & 27.083 \\
\hline
\end{tabular}

\begin{tabular}{|c|c|c|c|c|c|c|}
\hline \multicolumn{7}{|c|}{ Panel II: Imports (\% of pre-crisis GDP) } \\
\hline & (1) & (2) & (3) & (4) & (5) & (6) \\
\hline & $\mathbf{h}=\mathbf{0}$ & $\mathrm{h}=1$ & $\mathrm{~h}=\mathbf{2}$ & $\mathrm{h}=\mathbf{3}$ & $h=4$ & $h=5$ \\
\hline \multirow{2}{*}{\multicolumn{7}{|c|}{ Panel B: Banking crises }} \\
\hline \multicolumn{6}{|l|}{ Panel a: Total } & \\
\hline ATE-AIPW High & $\begin{array}{c}-1.995^{* * *} \\
(0.432)\end{array}$ & $\begin{array}{c}-9.200^{* * * *} \\
(0.807)\end{array}$ & $\begin{array}{c}-10.062^{* * * *} \\
(1.000)\end{array}$ & $\begin{array}{c}-9.171^{* * * *} \\
(1.149)\end{array}$ & $\begin{array}{c}-9.966 * * * \\
(1.395)\end{array}$ & $\begin{array}{c}-10.131 * * * \\
(1.696)\end{array}$ \\
\hline ATE-AIPW Low & $-3.188 * * *$ & $-7.324 * * *$ & $-9.441 * * *$ & $-11.890^{* * *}$ & $-14.729 * * *$ & $-20.120^{* * *}$ \\
\hline & $(0.450)$ & $(0.727)$ & $(0.936)$ & $(1.107)$ & $(1.338)$ & $(1.601)$ \\
\hline P-value High=Low & 0.001 & 0.000 & 0.198 & 0.000 & 0.000 & 0.000 \\
\hline Avg.(trade) in countries above cutoff & 3.997 & 8.298 & 12.933 & 17.784 & 22.317 & 27.123 \\
\hline Avg.(trade) in countries below cutoff & 3.028 & 5.932 & 8.867 & 12.317 & 15.947 & 19.893 \\
\hline
\end{tabular}

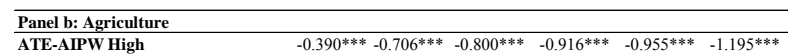

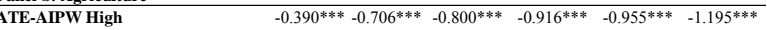
\begin{tabular}{lcccccc} 
& $(0.059)$ & $(0.097)$ & $(0.117)$ & $(0.130)$ & $(0.165)$ & $(0.191)$ \\
ATE-AIPW Low & 0.067 & $0.188^{*}$ & $-0.223^{*}$ & $-0.685 * *$ & $-1.128^{* * *}$ & $-1.969 * * *$ \\
\hline
\end{tabular} \begin{tabular}{lcccccc} 
& $(0.069)$ & $(0.105)$ & $(0.124)$ & $(0.134)$ & $(0.159)$ & $(0.186)$ \\
\hline P-value High=Low & 0.000 & 0.000 & 0.000 & 0.001 & 0.032 & 0.000
\end{tabular} \begin{tabular}{lllllll} 
Avg.(trade) in countries above cutoff & 0.000 & 0.000 & 0.000 & 0.001 & 0.032 & 0.000 \\
& 0.340 & 0.704 & 1.116 & 1.572 & 2.020 & 2.496 \\
\hline
\end{tabular} \begin{tabular}{lllllll} 
Avg.(trade) in countries below cutoff & 0.315 & 0.638 & 0.938 & 1.289 & 1.638 & 2.021 \\
\hline
\end{tabular}

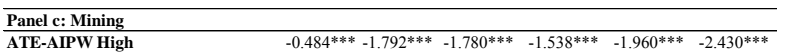

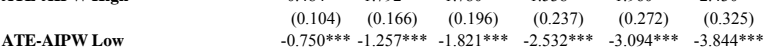
\begin{tabular}{lcccccc} 
& $(0.094)$ & $(0.161)$ & $(0.194)$ & $(0.235)$ & $(0.275)$ & $(0.323)$ \\
\hline P-value High=Low & 0.000 & 0.000 & 0.509 & 0.000 & 0.000 & 0.000
\end{tabular} $\begin{array}{lllllll}\text { Avg.(trade) in countries above cutoff } & 0.674 & 1.499 & 2.391 & 3.357 & 4.204 & 5.030\end{array}$ \begin{tabular}{lllllll} 
Avg.(trade) in countries below cutoff & 0.478 & 0.870 & 1.302 & 1.744 & 2.119 & 2.562 \\
\hline
\end{tabular}

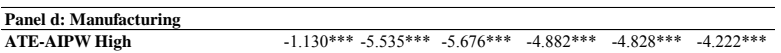
$\begin{array}{lllllll} & (0.248) & (0.495) & (0.601) & (0.680) & (0.838) & (1.040)\end{array}$

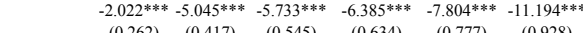
\begin{tabular}{lcccccc} 
& $(0.262)$ & $(0.417)$ & $(0.545)$ & $(0.634)$ & $(0.777)$ & $(0.928)$ \\
\hline P-value High=Low & 0.000 & 0.132 & 0.861 & 0.000 & 0.000 & 0.000
\end{tabular} \begin{tabular}{lllllll} 
Avg.(trade) in countries above cutoff & 2.295 & 4.655 & 7.205 & 9.771 & 12.191 & 14.835 \\
\hline
\end{tabular} \begin{tabular}{lllllll} 
Avg.(trade) in countries below cutoff & 1.738 & 3.435 & 5.104 & 7.116 & 9.417 & 11.889 \\
\hline
\end{tabular}

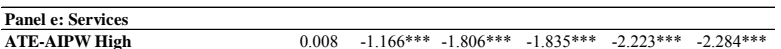
$\begin{array}{lllllll}(0.097) & (0.139) & (0.196) & (0.236) & (0.271) & (0.308)\end{array}$

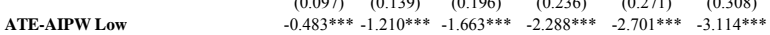

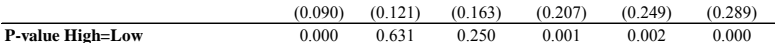
$\begin{array}{lllllll}\text { Avg(trade) in countries above cutoff } & 0.688 & 1.439 & 2.221 & 3.084 & 3.902 & 4.762\end{array}$ $\begin{array}{llllll} & \end{array}$ \begin{tabular}{lcccccc} 
Avg.(trade) in countries below cutoff & 0.496 & 0.988 & 1.522 & 2.168 & 2.773 & 3.422 \\
\hline Observations & 711 & 711 & 711 & 711 & 711 & 711
\end{tabular}

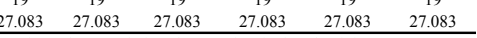
Notes: Robust standard errors clustered at the country-level in parentheses. ${ }^{*} p<0.1,{ }^{* *} \mathrm{p}<0.05,{ }^{* * *} \mathrm{p}<0.01$. IPW estimates. The dependent variables are 100 times the cummative change of agricultura, mining,

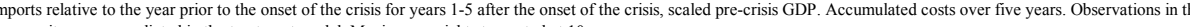
treated and control groups are weighted by the propensity scores predicted in the treatment model. Maximum weights truncated at 10. 
Table A.15c: Channels, Cumulative trade losses over five years after currency crises with higher and lower manufacturing exports

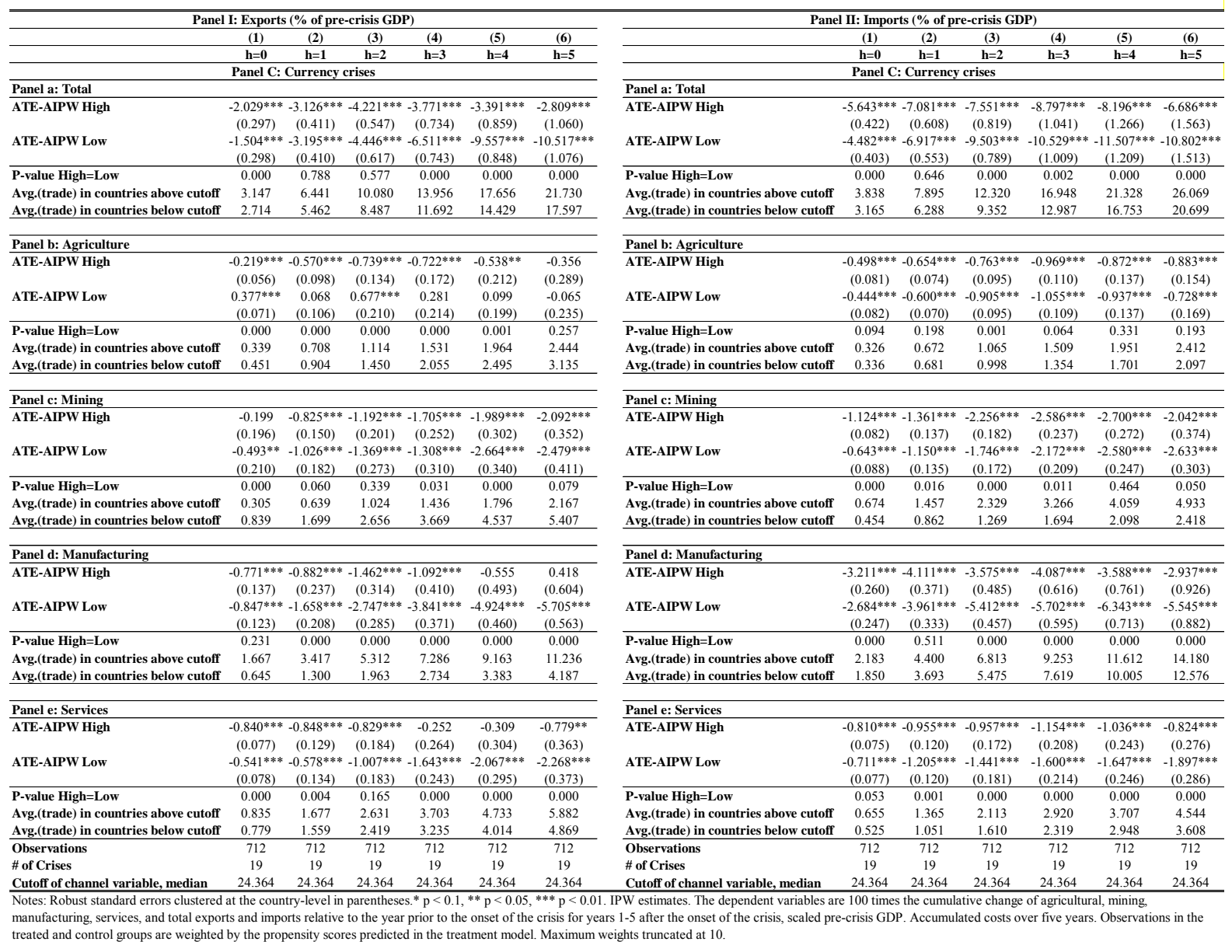


Table A.16a: Channels, Cumulative trade losses over five years after debt crises with higher and lower export diversification

\begin{tabular}{|c|c|c|c|c|c|c|}
\hline \multicolumn{7}{|c|}{ Panel I: Exports (\% of pre-crisis GDP) } \\
\hline & (1) & (2) & (3) & (4) & (5) & (6) \\
\hline & $\mathrm{h}=\mathbf{0}$ & $\mathrm{h}=1$ & $\mathrm{~h}=\mathbf{2}$ & $h=3$ & $h=4$ & $\mathrm{~h}=5$ \\
\hline \multicolumn{7}{|c|}{ Panel A: Debt crises } \\
\hline \multicolumn{7}{|l|}{ Panel a: Total } \\
\hline ATE-AIPW High & $\begin{array}{c}-1.600^{* * *} * \\
(0.277)\end{array}$ & $\begin{array}{c}-2.127 * * * * \\
(0.470)\end{array}$ & $\begin{array}{c}-2.328^{* * * *} \\
(0.639)\end{array}$ & $\begin{array}{c}-4.299 * * * \\
(0.843)\end{array}$ & $\begin{array}{c}-5.555^{* * *} \\
(1.031)\end{array}$ & $\begin{array}{c}-5.678^{* * *} \\
(1.271)\end{array}$ \\
\hline ATE-AIPW Low & $\begin{array}{c}-1.104 * * * * \\
(0.322)\end{array}$ & $\begin{array}{c}-3.529 * * * * \\
(0.443)\end{array}$ & $\begin{array}{c}-5.243 * * * \\
(0.636)\end{array}$ & $\begin{array}{c}-7.874 * * * \\
(0.896)\end{array}$ & $\begin{array}{c}-8.565 * * * \\
(1.042)\end{array}$ & $\begin{array}{c}-8.603^{* * *} \\
(1.232)\end{array}$ \\
\hline P-value High=Low & 0.051 & 0.000 & 0.000 & 0.000 & 0.000 & 0.000 \\
\hline Avg.(trade) in countries above cutoff & 3.217 & 6.663 & 10.494 & 14.540 & 18.218 & 22.318 \\
\hline Avg.(trade) in countries below cutoff & 2.355 & 4.456 & 6.711 & 9.156 & 11.463 & 14.078 \\
\hline \multicolumn{7}{|l|}{ Panel b: Agriculture } \\
\hline ATE-AIPW High & $\begin{array}{c}-0.631 * * * * \\
(0.111)\end{array}$ & $\begin{array}{c}-0.356 * * * \\
(0.107)\end{array}$ & $\begin{array}{c}-0.325^{* *} \\
(0.156)\end{array}$ & $\begin{array}{c}-0.387^{* *} \\
(0.195)\end{array}$ & $\begin{array}{c}-0.173 \\
(0.235)\end{array}$ & $\begin{array}{l}0.549^{*} \\
(0.292)\end{array}$ \\
\hline ATE-AIPW Low & $\begin{array}{c}-0.267 * * * * \\
(0.082)\end{array}$ & $\begin{array}{c}-0.127 \\
(0.102)\end{array}$ & $\begin{array}{c}0.119 \\
(0.159)\end{array}$ & $\begin{array}{c}0.706^{* *} \\
(0.274)\end{array}$ & $\begin{array}{c}0.032 \\
(0.290)\end{array}$ & $\begin{array}{c}0.094 \\
(0.284)\end{array}$ \\
\hline P-value High=Low & 0.000 & 0.007 & 0.000 & 0.000 & 0.411 & 0.092 \\
\hline Avg.(trade) in countries above cutoff & 0.371 & 0.766 & 1.213 & 1.653 & 2.107 & 2.602 \\
\hline Avg.(trade) in countries below cutoff & 0.394 & 0.795 & 1.293 & 1.911 & 2.239 & 2.793 \\
\hline \multicolumn{7}{|l|}{ Panel c: Mining } \\
\hline ATE-AIPW High & $\begin{array}{c}-0.287^{* * *} * \\
(0.109)\end{array}$ & $\begin{array}{c}-0.273 \\
(0.191)\end{array}$ & $\begin{array}{c}-0.323 \\
(0.269)\end{array}$ & $\begin{array}{c}-0.412 \\
(0.344)\end{array}$ & $\begin{array}{c}-0.440 \\
(0.431)\end{array}$ & $\begin{array}{c}-0.403 \\
(0.503)\end{array}$ \\
\hline ATE-AIPW Low & $\begin{array}{c}0.675^{* * *} * \\
(0.200)\end{array}$ & $\begin{array}{c}0.303 \\
(0.238)\end{array}$ & $\begin{array}{c}-0.273 \\
(0.297) \\
\end{array}$ & $\begin{array}{c}-1.781 * * * \\
(0.388)\end{array}$ & $\begin{array}{l}-0.860^{*} \\
(0.455)\end{array}$ & $\begin{array}{c}0.154 \\
(0.611)\end{array}$ \\
\hline P-value High=Low & 0.000 & 0.002 & 0.754 & 0.000 & 0.111 & 0.210 \\
\hline Avg.(trade) in countries above cutoff & 0.409 & 0.908 & 1.515 & 2.157 & 2.718 & 3.256 \\
\hline Avg.(trade) in countries below cutoff & 0.793 & 1.434 & 2.029 & 2.677 & 3.204 & 3.837 \\
\hline \multicolumn{7}{|l|}{ Panel d: Manufacturing } \\
\hline ATE-AIPW High & $\begin{array}{c}-0.652 * * * * \\
(0.141)\end{array}$ & $\begin{array}{c}-0.822 * * * * \\
(0.261)\end{array}$ & $\begin{array}{c}-1.458^{* * * *} \\
(0.323)\end{array}$ & $\begin{array}{c}-2.985^{* * *} \\
(0.413)\end{array}$ & $\begin{array}{c}-3.864 * * * \\
(0.512)\end{array}$ & $\begin{array}{c}-4.319^{* * *} \\
(0.624)\end{array}$ \\
\hline ATE-AIPW Low & $\begin{array}{c}-0.928^{* * * *} \\
(0.129)\end{array}$ & $\begin{array}{c}-2.141^{* * * *} \\
(0.225)\end{array}$ & $\begin{array}{c}-3.031^{* * * *} \\
(0.316)\end{array}$ & $\begin{array}{c}-4.186^{* * * *} \\
(0.407)\end{array}$ & $\begin{array}{c}-4.956 * * * \\
(0.502)\end{array}$ & $\begin{array}{c}-5.551^{* * *} \\
(0.610)\end{array}$ \\
\hline P-value High=Low & 0.000 & 0.000 & 0.000 & 0.000 & 0.000 & 0.000 \\
\hline Avg.(trade) in countries above cutoff & 1.567 & 3.224 & 5.004 & 6.901 & 8.624 & 10.625 \\
\hline Avg.(trade) in countries below cutoff & 0.496 & 0.941 & 1.399 & 1.855 & 2.397 & 2.863 \\
\hline \multicolumn{7}{|l|}{ Panel e: Services } \\
\hline ATE-AIPW High & $\begin{array}{c}-0.031 \\
(0.077)\end{array}$ & $\begin{array}{c}-0.677^{* * * *} \\
(0.128)\end{array}$ & $\begin{array}{c}-0.221 \\
(0.189)\end{array}$ & $\begin{array}{c}-0.515^{* *} \\
(0.237)\end{array}$ & $\begin{array}{c}-1.079^{* * *} * \\
(0.284)\end{array}$ & $\begin{array}{c}-1.505^{* * *} \\
(0.340)\end{array}$ \\
\hline ATE-AIPW Low & $\begin{array}{c}-0.584 * * * \\
(0.074)\end{array}$ & $\begin{array}{c}-1.564 * * * \\
(0.127)\end{array}$ & $\begin{array}{c}-2.059 * * * \\
(0.189)\end{array}$ & $\begin{array}{c}-2.614 * * * \\
(0.243)\end{array}$ & $\begin{array}{c}-2.780^{* * * *} \\
(0.285)\end{array}$ & $\begin{array}{c}-3.301^{* * *} \\
(0.343)\end{array}$ \\
\hline P-value High=Low & 0.000 & 0.000 & 0.000 & 0.000 & 0.000 & 0.000 \\
\hline Avg.(trade) in countries above cutoff & 0.869 & 1.764 & 2.762 & 3.829 & 4.769 & 5.835 \\
\hline Avg.(trade) in countries below cutoff & 0.673 & 1.286 & 1.990 & 2.713 & 3.624 & 4.585 \\
\hline Observations & 707 & 707 & 707 & 707 & 707 & 707 \\
\hline \# of Crises & 19 & 19 & 19 & 19 & 19 & 19 \\
\hline Cutoff of channel variable, median & -3.200 & -3.200 & -3.200 & -3.200 & -3.200 & -3.200 \\
\hline
\end{tabular}

\begin{tabular}{|c|c|c|c|c|c|c|}
\hline \multicolumn{7}{|c|}{ Panel II: Imports (\% of pre-crisis GDP) } \\
\hline & (1) & (2) & (3) & (4) & (5) & (6) \\
\hline & $\mathbf{h}=\mathbf{0}$ & $\mathrm{h}=1$ & $\mathrm{~h}=2$ & $\mathrm{~h}=\mathbf{3}$ & $h=4$ & $h=5$ \\
\hline \multicolumn{7}{|c|}{ Panel A: Debt crises } \\
\hline \multicolumn{7}{|l|}{ Panel a: Total } \\
\hline ATE-AIPW High & $\begin{array}{c}-2.183 * * * * \\
(0.459)\end{array}$ & $\begin{array}{c}-4.744 * * * \\
(0.625)\end{array}$ & $\begin{array}{c}-4.650 * * * \\
(0.924)\end{array}$ & $\begin{array}{c}-4.192 * * * \\
(1.146)\end{array}$ & $\begin{array}{c}-5.084^{* * * *} \\
(1.356)\end{array}$ & $\begin{array}{c}-4.638^{* * *} \\
(1.605)\end{array}$ \\
\hline ATE-AIPW Low & $-4.309 * * *$ & $-6.566 * * *$ & $-8.070^{* * * *}$ & $-11.081^{* * *}$ & $-12.402 * * *$ & $-13.761 * * *$ \\
\hline & $(0.516)$ & $(0.680)$ & $(0.992)$ & $(1.186)$ & $(1.407)$ & $(1.605)$ \\
\hline P-value High=Low & 0.000 & 0.000 & 0.000 & 0.000 & 0.000 & 0.000 \\
\hline Avg.(trade) in countries above cutoff & 3.849 & 7.770 & 12.059 & 16.650 & 21.042 & 25.598 \\
\hline
\end{tabular}

\begin{tabular}{lllllll} 
Avg.(trade) in countries above cutoff & 3.849 & 7.770 & 12.059 & 16.650 & 21.042 & 25.598 \\
Avg.(trade) in countries below cutoff & 2.883 & 5.931 & 8.759 & 12.002 & 15.415 & 19.295 \\
\hline
\end{tabular}

\begin{tabular}{lcccccc}
\hline Panel b: Agriculture & \multicolumn{10}{l}{} \\
\hline ATE-AIPW High & 0.002 & $-0.455^{* * *}$ & $-0.295^{* *}$ & -0.266 & $-0.461^{* * *}$ & $-0.342^{*}$ \\
& $(0.116)$ & $(0.107)$ & $(0.139)$ & $(0.177)$ & $(0.161)$ & $(0.188)$
\end{tabular}

$\begin{array}{lrrrrrr} & (0.116) & (0.107) & (0.139) & (0.177) & (0.161) & (0.188) \\ \text { ATE-AIPW Low } & -0.357 * * & -0.661 * * & -0.948 * * * & -1.303^{* * *} & -1.634^{* * *} & -1.483^{* * *}\end{array}$

\begin{tabular}{lcccccc} 
& $(0.121)$ & $(0.109)$ & $(0.143)$ & $(0.181)$ & $(0.162)$ & $(0.190)$ \\
\hline P-value High=Low & 0.000 & 0.000 & 0.000 & 0.000 & 0.000 & 0.000
\end{tabular} \begin{tabular}{lllllll} 
Avg.(trade) in countries above cutoff & 0.340 & 0.691 & 0.000 & 0.000 & 0.000 & 0.000 \\
& 0.308 & 0.63 & 0.909 & 1.509 & 1.933 & 2.380 \\
\hline
\end{tabular} \begin{tabular}{lllllll} 
Avg.(trade) in countries below cutoff & 0.308 & 0.634 & 0.909 & 1.290 & 1.642 & 2.027 \\
\hline
\end{tabular}

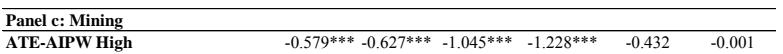

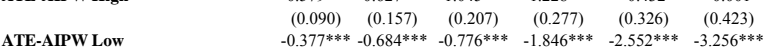
\begin{tabular}{lcccccc} 
& $(0.093)$ & $(0.174)$ & $(0.214)$ & $(0.263)$ & $(0.315)$ & $(0.370)$ \\
\hline P-value High=Low & 0.000 & 0.654 & 0.067 & 0.001 & 0.000 & 0.000
\end{tabular} \begin{tabular}{lllllll} 
Avg.(trade) in countries above cutoff & 0.654 & 1.341 & 2.095 & 2.924 & 3.671 & 4.403 \\
Avg.(trade) in countries below cutoff & 0.416 & 0.915 & 1.448 & 1.942 & 2.316 & 2.745 \\
\hline
\end{tabular} Avg.(trade) in countries below cutof 0.046

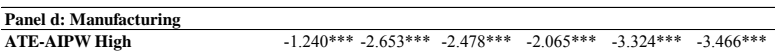

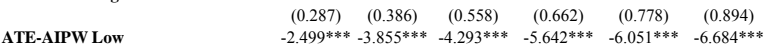

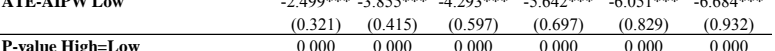
$\begin{array}{lllllll} & 0.000 & 0.000 & 0.000 & 0.000 & 0.000 & 0.000 \\ \text { Avg.(trade) in countries above cutoff } & 2.230 & 4.450 & 6.843 & 9.398 & 11.911 & 14.567\end{array}$ \begin{tabular}{lllllll} 
Avg.(trade) in countries below cutoff & 1.601 & 3.242 & 4.783 & 6.422 & 8.338 & 10.520 \\
\hline
\end{tabular}

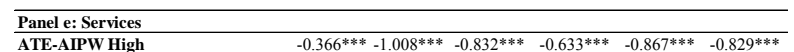

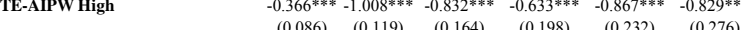

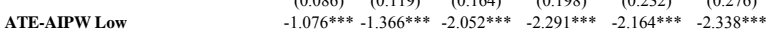
\begin{tabular}{lcccccc} 
& $(0.103)$ & $(0.137)$ & $(0.198)$ & $(0.227)$ & $(0.275)$ & $(0.303)$ \\
\hline P-value High=Low & 0.000 & 0.001 & 0.000 & 0.000 & 0.000 & 0.000
\end{tabular} $\begin{array}{lllllll}\text { Avg.(trade) in countries above cutoff } & 0.626 & 1.288 & 2.034 & 2.819 & 3.527 & 4.248\end{array}$

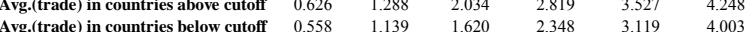
\begin{tabular}{lccccccc} 
Avg.(trade) in countries below cutoff & 0.558 & 1.139 & 1.620 & 2.348 & 3.119 & 4.003 \\
\hline Observations & 707 & 707 & 707 & 707 & 707 & 707
\end{tabular} \# of Crises \begin{tabular}{cccccc}
19 & 19 & 19 & 19 & 19 & 19 \\
-3.200 & -3.200 & -3.200 & -3.200 & -3.200 & -3.200 \\
\hline
\end{tabular} Notes: Robust standard errors clustered at the country-level in parentheses." $\mathrm{p}<0.1,+\mathrm{p}<0.05, \cdots \mathrm{p}<0.01$. IPW estimates. The dependent variables are 100 times the cumulative change of agricultural, mining,

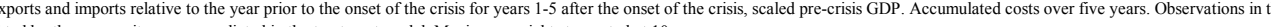
treated and control groups are weighted by the propensity scores predicted in the treatment model. Maximum weights truncated at 10. 
Table A.16b: Channels, Cumulative trade losses over five years after banking crises with higher and lower export diversification

\begin{tabular}{|c|c|c|c|c|c|c|}
\hline \multicolumn{7}{|c|}{ Panel I: Exports (\% of pre-crisis GDP) } \\
\hline & (1) & (2) & (3) & (4) & (5) & (6) \\
\hline & $\mathrm{h}=\mathbf{0}$ & $\mathrm{h}=1$ & $\mathrm{~h}=\mathbf{2}$ & $h=3$ & $h=4$ & $\mathrm{~h}=5$ \\
\hline \multicolumn{7}{|c|}{ Panel B: Banking crises } \\
\hline \multicolumn{7}{|l|}{ Panel a: Total } \\
\hline ATE-AIPW High & $\begin{array}{c}-0.991 * * * \\
(0.294)\end{array}$ & $\begin{array}{c}-6.176 * * * \\
(0.477)\end{array}$ & $\begin{array}{c}-5.784 * * * \\
(0.575)\end{array}$ & $\begin{array}{c}-4.618 * * * \\
(0.730)\end{array}$ & $\begin{array}{c}-6.971 * * * \\
(0.893)\end{array}$ & $\begin{array}{c}-7.303 * * * \\
(1.113)\end{array}$ \\
\hline \multirow[t]{2}{*}{ ATE-AIPW Low } & $-1.383^{* * * *}$ & $-4.750^{* * * *}$ & $\begin{array}{l}-6.592 * * * \\
-0580 *\end{array}$ & - $-8.249 * * *$ & $-11.364 * * *$ & * $-12.734 * * *$ \\
\hline & $\begin{array}{c}(0.293) \\
0.108\end{array}$ & $(0.479)$ & $(0.580)$ & $(0.730)$ & $(0.901)$ & $\frac{(1.084)}{0.000}$ \\
\hline Avg.(trade) in countries above $\mathrm{ct}$ & 3.742 & 7.485 & $\begin{array}{l}.001 \\
11.588\end{array}$ & $\begin{array}{l}.0 .000 \\
15.922\end{array}$ & 19.878 & 24.287 \\
\hline Avg.(trade) in countries below cutoff & 2.528 & 5.211 & 8.193 & 11.371 & 14.286 & 17.555 \\
\hline \multicolumn{7}{|l|}{ Panel b: Agriculture } \\
\hline ATE-AIPW High & $\begin{array}{l}-0.107^{*} \\
(0.056)\end{array}$ & $\begin{array}{c}-0.521^{* * * *} \\
(0.084)\end{array}$ & $\begin{array}{c}-0.668^{* * *} \\
(0.113)\end{array}$ & $\begin{array}{c}-0.638^{* * *} \\
(0.145)\end{array}$ & $\begin{array}{c}-0.617 * * * \\
(0.177)\end{array}$ & $\begin{array}{c}-0.780^{* * * *} \\
(0.201)\end{array}$ \\
\hline ATE-AIPW Low & $\begin{array}{l}-0.009 \\
(0.063)\end{array}$ & $\begin{array}{c}-0.559 * * * \\
(0.093)\end{array}$ & $\begin{array}{c}-0.984 * * * \\
(0.131)\end{array}$ & $\begin{array}{c}-1.195 * * * \\
(0.150)\end{array}$ & $\begin{array}{c}-1.568 * * * \\
(0.165)\end{array}$ & $\begin{array}{c}-2.182 * * * \\
(0.179)\end{array}$ \\
\hline P-value High=Low & 0.054 & 0.571 & 0.002 & 0.000 & 0.000 & 0.000 \\
\hline Avg.(trade) in countries above cutoff & 0.420 & 0.849 & 1.308 & 1.808 & 2.304 & 2.872 \\
\hline Avg.(trade) in countries below cutoff & 0.352 & 0.729 & 1.191 & 1.673 & 2.046 & 2.524 \\
\hline \multicolumn{7}{|l|}{ Panel c: Mining } \\
\hline ATE-AIPW High & $\begin{array}{c}-0.421^{* * * *} \\
(0.137)\end{array}$ & $\begin{array}{c}-1.229 * * * \\
(0.222)\end{array}$ & $\begin{array}{c}-1.447^{* * * *} \\
(0.242)\end{array}$ & $\begin{array}{c}-1.651^{* * * *} \\
(0.268)\end{array}$ & $\begin{array}{c}-2.418^{* * *} \\
(0.320)\end{array}$ & $\begin{array}{c}-2.692^{* * *} \\
(0.401)\end{array}$ \\
\hline ATE-AIPW Low & $\begin{array}{c}0.041 \\
(0.165)\end{array}$ & $\begin{array}{c}-0.602^{* *} \\
(0.235)\end{array}$ & $\begin{array}{l}-0.422 \\
(0.272)\end{array}$ & $\begin{array}{c}-0.968^{* * * *} \\
(0.313)\end{array}$ & $\begin{array}{c}-1.904 * * * \\
(0.352)\end{array}$ & $\begin{array}{r}-0.737 \\
(0.478) \\
\end{array}$ \\
\hline P-value High=Low & 0.000 & 0.000 & 0.000 & 0.000 & 0.001 & 0.000 \\
\hline Avg.(trade) in countries above cutoff & 0.382 & 0.773 & 1.206 & 1.633 & 1.959 & 2.286 \\
\hline Avg.(trade) in countries below cutoff & 0.593 & 1.218 & 1.924 & 2.696 & 3.383 & 4.088 \\
\hline \multicolumn{7}{|l|}{ Panel d: Manufacturing } \\
\hline ATE-AIPW High & $\begin{array}{l}-0.048 \\
(0.159)\end{array}$ & $\begin{array}{c}-2.576 * * * \\
(0.256)\end{array}$ & $\begin{array}{c}-1.749 * * * \\
(0.323)\end{array}$ & $\begin{array}{l}-0.557 \\
(0.427)\end{array}$ & $\begin{array}{c}-1.365 * * \\
(0.533)\end{array}$ & $\begin{array}{l}-1.184^{*} \\
(0.666)\end{array}$ \\
\hline ATE-AIPW Low & $\begin{array}{c}-0.641^{* * *} \\
(0.141)\end{array}$ & $-1.501 * * *$ & $\begin{array}{c}-2.410^{* * *} \\
(0.377)\end{array}$ & $\begin{array}{c}-3.154 * * * \\
(0.477)\end{array}$ & $\begin{array}{c}-4.026 * * * \\
(0.539)\end{array}$ & $\begin{array}{c}-5.059 * * * \\
(0.644)\end{array}$ \\
\hline P-value High=Low & 0.000 & $\frac{0.2000}{0.000}$ & 0.010 & 0.000 & 0.000 & 0.000 \\
\hline Avg.(trade) in countries above cutoff & 2.070 & 4.176 & 6.469 & 8.908 & 11.156 & 13.706 \\
\hline Avg.(trade) in countries below cutoff & 0.800 & 1.661 & 2.559 & 3.505 & 4.400 & 5.405 \\
\hline \multicolumn{7}{|l|}{ Panel e: Services } \\
\hline ATE-AIPW High & $\begin{array}{c}-0.416^{* * * *} \\
(0.089)\end{array}$ & $\begin{array}{c}-1.850^{* * * *} \\
(0.138)\end{array}$ & $\begin{array}{c}-1.921^{* * *} \\
(0.198)\end{array}$ & $\begin{array}{c}-1.772^{* * * *} \\
(0.282)\end{array}$ & $\begin{array}{c}-2.571^{* * *} \\
(0.358)\end{array}$ & $\begin{array}{c}-2.647^{* * *} \\
(0.491)\end{array}$ \\
\hline ATE-AIPW Low & $\begin{array}{c}-0.774^{* * * *} \\
(0.099)\end{array}$ & $-2.088 * * *$ & $-2.776 * *$ & $-2.932 * * *$ & $-3.867 * * *$ & $\begin{array}{c}-4.755^{* * *} \\
(0.448)\end{array}$ \\
\hline P-value High=Low & 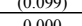 & $(0.165)$ & $(0.230)$ & $(0.298)$ & $(0.378)$ & $(0.448)$ \\
\hline Avg.(trade) in countr & 0.870 & $\begin{array}{l}0.687 \\
1.687\end{array}$ & $\begin{array}{l}0.600 \\
2.605\end{array}$ & 3.574 & 4.459 & $\begin{array}{l}0.400 \\
5.422\end{array}$ \\
\hline Avg.(trade) in countries below cutoff & 0.784 & 1.602 & 2.519 & 3.496 & 4.456 & 5.538 \\
\hline Observations & 710 & 710 & 710 & 710 & 710 & 710 \\
\hline \# of Crises & 18 & 18 & 18 & 18 & 18 & 18 \\
\hline Cutoff of channel variable, median & -2.445 & -2.445 & -2.445 & -2.445 & -2.445 & -2.445 \\
\hline
\end{tabular}

\begin{tabular}{|c|c|c|c|c|c|c|}
\hline \multicolumn{7}{|c|}{ Panel II: Imports (\% of pre-crisis GDP) } \\
\hline & (1) & (2) & (3) & (4) & (5) & (6) \\
\hline & $\mathrm{h}=\mathbf{0}$ & $\mathrm{h}=\mathbf{1}$ & $\mathrm{h}=\mathbf{2}$ & $\mathrm{h}=\mathbf{3}$ & $h=4$ & $\mathrm{~h}=5$ \\
\hline \multicolumn{7}{|c|}{ Panel B: Banking crises } \\
\hline \multicolumn{7}{|l|}{ Panel a: Total } \\
\hline ATE-AIPW High & $\begin{array}{c}-2.628^{* * *} \\
(0.421)\end{array}$ & $\begin{array}{c}-10.660^{* * * *} \\
(0.757)\end{array}$ & $\begin{array}{c}-11.084^{* * *} \\
(0.949)\end{array}$ & $\begin{array}{c}-10.113^{* * *} \\
(1.136)\end{array}$ & $\begin{array}{c}-11.891 * * * \\
(1.448)\end{array}$ & $\begin{array}{c}-12.633 * * * \\
(1.766)\end{array}$ \\
\hline ATE-AIPW Low & $-2.252^{* * *}$ & $-6.143 * * *$ & $-9.148^{* * *}$ & $-11.568^{* * *}$ & $-13.811 * * *$ & $-18.793 * * *$ \\
\hline & $(0.447)$ & $(0.721)$ & $(0.925)$ & $(1.113)$ & $(1.440)$ & $(1.700)$ \\
\hline P-value High=Low & 0.310 & 0.000 & 0.000 & 0.002 & 0.007 & 0.000 \\
\hline & 3.906 & 7.937 & & 16.945 & 21.150 & 25.699 \\
\hline Avg.(trade) in countries below & 3.395 & 6.870 & 10.444 & 14.451 & 18.529 & 22.795 \\
\hline
\end{tabular}

\begin{tabular}{lcccccc}
\hline Panel b: Agriculture & \multicolumn{10}{c}{} \\
\hline ATE-AIPW High & $-0.310^{* * *}$ & $-0.835^{* * *}$ & $-0.947^{* * *}$ & $-1.102^{* * *}$ & $-1.282^{* * *}$ & $-1.517^{* * *}$ \\
& $(0.054)$ & $(0.090)$ & $(0.111)$ & $(0.136)$ & $(0.173)$ & $(0.204)$
\end{tabular}

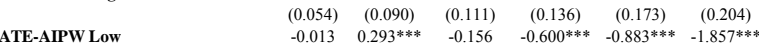

\begin{tabular}{lllllll} 
ATE-AIPW Low & -0.013 & $0.293^{* * *}$ & -0.156 & $-0.600^{* * *}$ & $-0.883^{* * *}$ & $-1.857^{* * *}$ \\
\hline
\end{tabular}

\begin{tabular}{lcccccc}
\hline P-value High=Low & $(0.073)$ & $(0.108)$ & $(0.128)$ & $(0.144)$ & $(0.180)$ & $(0.205)$ \\
\hline
\end{tabular} \begin{tabular}{lllllll} 
Avg.(trade) in countries above cutoff & 0.000 & 0.000 & 0.000 & 0.000 & 0.000 & 0.000 \\
& 0.278 & 0.575 & 0.919 & 1.274 & 1.634 & 2.002 \\
\hline
\end{tabular} \begin{tabular}{lllllll} 
Avg.(trade) in countries below cutoff & 0.362 & 0.736 & 1.110 & 1.554 & 1.985 & 2.452 \\
\hline
\end{tabular}

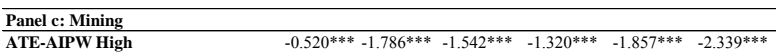

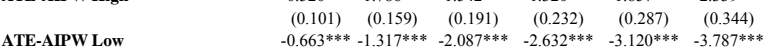
\begin{tabular}{lcccccc} 
& $(0.096)$ & $(0.157)$ & $(0.190)$ & $(0.228)$ & $(0.285)$ & $(0.340)$ \\
\hline P-value High=Low & 0.008 & 0.000 & 0.000 & 0.000 & 0.000 & 0.000
\end{tabular} \begin{tabular}{lllllll} 
Avg.(trade) in countries above cutoff & 0.741 & 1.542 & 2.417 & 3.327 & 4.125 & 4.902 \\
\hline
\end{tabular} \begin{tabular}{lllllll} 
Avg.(trade) in countries below cutoff & 0.498 & 1.036 & 1.621 & 2.256 & 2.809 & 3.383 \\
\hline
\end{tabular}

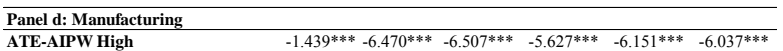
$\begin{array}{lllllll} & (0.251) & (0.465) & (0.573) & (0.670) & (0.857) & (1.067)\end{array}$

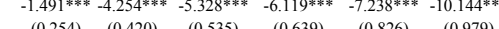
\begin{tabular}{lcccccc}
\hline P-value High=Low & 0.804 & 0.000 & 0.000 & 0.128 & 0.033 & 0.000 \\
& 0.825 & $(0.420$ & $(0.535)$ & $(0.639)$ & $(0.826$ & $(0.979)$ \\
\hline
\end{tabular} \begin{tabular}{lllllll} 
Avg.(trade) in countries above cutoff & 2.272 & 4.538 & 7.019 & 9.582 & 11.941 & 14.602 \\
\hline
\end{tabular} \begin{tabular}{lllllll} 
Avg.(trade) in countries below cutoff & 1.931 & 3.872 & 5.842 & 7.993 & 10.338 & 12.785 \\
\hline
\end{tabular}

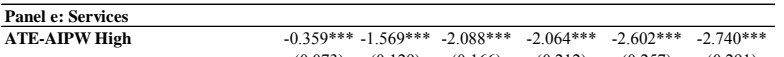
\begin{tabular}{ccccccc}
$-0.359^{* * *}$ & $-1.569^{* * *}$ & $-2.088^{* * *}$ & $-2.064^{* * *}$ & $-2.602^{* * *}$ & $-2.740 *$ \\
\hline & $(0.073)$ & $(0.129)$ & $(0.166)$ & $(0.212)$ & $(0.257)$ & $(0.291)$
\end{tabular} $\begin{array}{lllllll}\text { ATE-AIPW Low } & -0.084 & -0.864^{* * *} & -1.577^{* * *} & -2.218^{* * *} & -2.569^{* * *} & -3.005 * * *\end{array}$ \begin{tabular}{lcccccc}
\hline P-value High=Low & $(0.110)$ & $(0.123)$ & $(0.182)$ & $(0.222)$ & $(0.273)$ & $(0.314)$ \\
\hline
\end{tabular} $\begin{array}{lllllll}\text { Avg.(trade) in countries above cutoff } & 0.614 & 1.282 & 2.005 & 2.762 & 3.450 & 4.193\end{array}$

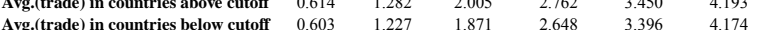
\begin{tabular}{lcccccc} 
Avg.(trade) in countries below cutoff & 0.603 & 1.227 & 1.871 & 2.648 & 3.396 & 4.174 \\
\hline Observations & 710 & 710 & 710 & 710 & 710 & 710
\end{tabular}

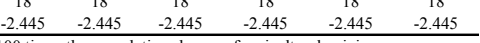
Notes: Robust standard errors clustered at the country-level in parentheses. ${ }^{*} \mathrm{p}<0.1,{ }^{* *} \mathrm{p}<0.05,{ }^{* * *} \mathrm{p}<0.01$. IPW estimates. The dependent variables are 100 .

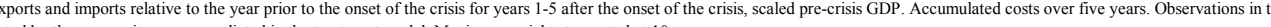
treated and control groups are weighted by the propensity scores predicted in the treatment model. Maximum weights truncated at 10 . 
Table A.16c: Channels, Cumulative trade losses over five years after currency crises with higher and lower export diversification

\begin{tabular}{|c|c|c|c|c|c|c|}
\hline \multicolumn{7}{|c|}{ Panel I: Exports (\% of pre-crisis GDP) } \\
\hline & (1) & (2) & (3) & (4) & (5) & (6) \\
\hline & $\mathrm{h}=\mathbf{0}$ & $\mathrm{h}=1$ & $\mathrm{~h}=\mathbf{2}$ & $h=3$ & $h=4$ & $h=5$ \\
\hline \multicolumn{7}{|c|}{ Panel C: Currency crises } \\
\hline \multicolumn{7}{|l|}{ Panel a: Total } \\
\hline ATE-AIPW High & $\begin{array}{c}-1.563^{* * * *} \\
(0.282)\end{array}$ & $\begin{array}{c}-2.033^{* * * *} \\
(0.404)\end{array}$ & $\begin{array}{c}-3.514 * * * \\
(0.540)\end{array}$ & $\begin{array}{c}*-3.720^{* * * *} \\
(0.727)\end{array}$ & $\begin{array}{c}-3.663 * * * \\
(0.860)\end{array}$ & $\begin{array}{c}-2.633^{* *} \\
(1.098)\end{array}$ \\
\hline \multirow[t]{2}{*}{ ATE-AIPW Low } & $-2.035 * * *$ & $-4.481 * * *$ & $-5.249 * * *$ & $*-6.774 * * *$ & $-9.782 * * *$ & $-11.354 * * *$ \\
\hline & $(0.285)$ & $(0.405)$ & $(0.604)$ & $(0.721)$ & $(0.833)$ & $(0.974)$ \\
\hline P-value High=Low & 0.001 & 0.000 & 0.000 & 0.000 & 0.000 & 0.000 \\
\hline Avg.(trade) in countries above cutoff & 3.590 & 7.303 & 11.296 & 15.768 & 19.602 & 23.775 \\
\hline Avg.(trade) in countries below cutoff & 2.526 & 5.128 & 8.085 & 11.048 & 13.954 & 17.291 \\
\hline \multicolumn{7}{|l|}{ Panel b: Agriculture } \\
\hline ATE-AIPW High & $\begin{array}{l}-0.046 \\
(0.054)\end{array}$ & $\begin{array}{c}-0.293^{* * * *} \\
(0.082)\end{array}$ & $\begin{array}{c}-0.312^{* * * *} \\
(0.112)\end{array}$ & $\begin{array}{r}-0.265^{*} \\
(0.157)\end{array}$ & $\begin{array}{c}-0.117 \\
(0.186)\end{array}$ & $\begin{array}{c}0.093 \\
(0.249)\end{array}$ \\
\hline \multirow[t]{2}{*}{ ATE-AIPW Low } & $0.278^{* * *}$ & -0.062 & $0.421^{* *}$ & -0.026 & -0.218 & -0.298 \\
\hline & $(0.072)$ & $(0.107)$ & $(0.213)$ & $(0.213)$ & $(0.190)$ & $(0.221)$ \\
\hline P-value High=Low & 0.000 & 0.014 & 0.000 & 0.226 & 0.532 & 0.082 \\
\hline Avg.(trade) in countries above cutoff & 0.435 & 0.878 & 1.344 & 1.820 & 2.271 & 2.796 \\
\hline Avg.(trade) in countries below cutoff & 0.334 & 0.696 & 1.153 & 1.651 & 2.046 & 2.548 \\
\hline \multicolumn{7}{|l|}{ Panel c: Mining } \\
\hline \multirow[t]{2}{*}{ ATE-AIPW High } & -0.262 & $-0.585 * * *$ & $-0.822^{* * *}$ & $*-1.192 * * *$ & $-1.425^{* * *}$ & $-1.287 * * *$ \\
\hline & $(0.169)$ & $(0.150)$ & $(0.205)$ & $(0.261)$ & $(0.313)$ & $(0.383)$ \\
\hline \multirow[t]{2}{*}{ ATE-AIPW Low } & $-0.539^{* * *}$ & $*-1.380^{* * * *}$ & $-1.874 * * *$ & $*-1.913^{* * * *}$ & $-3.437 * * *$ & $-3.577^{* * *}$ \\
\hline & $(0.185)$ & $(0.178)$ & $(0.262)$ & $(0.296)$ & $(0.318)$ & $(0.373)$ \\
\hline P-value High=Low & 0.001 & 0.000 & 0.000 & 0.000 & 0.000 & 0.000 \\
\hline Avg.(trade) in countries above cutoff & 0.355 & 0.729 & 1.126 & 1.540 & 1.857 & 2.149 \\
\hline Avg.(trade) in countries below cutoff & 0.633 & 1.294 & 2.053 & 2.869 & 3.597 & 4.365 \\
\hline \multicolumn{7}{|l|}{ Panel d: Manufacturing } \\
\hline \multirow[t]{2}{*}{ ATE-AIPW High } & $-0.565^{* * *}$ & -0.338 & $-0.976 * * *$ & ${ }^{*}-1.011^{* *}$ & $-1.006 * *$ & -0.123 \\
\hline & $(0.134)$ & $(0.227)$ & $(0.305)$ & $(0.412)$ & $(0.500)$ & $(0.602)$ \\
\hline \multirow[t]{2}{*}{ ATE-AIPW Low } & $-1.110^{* * *}$ & $*-2.462 * * *$ & $-3.531 * * *$ & * - $-4.274 * * *$ & $-4.888 * * *$ & $-5.749 * * *$ \\
\hline & $(0.126)$ & $(0.214)$ & $(0.290)$ & $(0.372)$ & $(0.464)$ & $(0.560)$ \\
\hline P-value High=Low & 0.000 & 0.000 & 0.000 & 0.000 & 0.000 & 0.000 \\
\hline Avg.(trade) in countries above cutoff & 1.933 & 3.972 & 6.128 & 8.669 & 10.862 & 13.242 \\
\hline Avg.(trade) in countries below cutoff & 0.781 & 1.572 & 2.438 & 3.165 & 3.970 & 4.954 \\
\hline \multicolumn{7}{|l|}{ Panel e: Services } \\
\hline \multirow[t]{2}{*}{ ATE-AIPW High } & $-0.690^{* * * *}$ & $k^{*}-0.818^{* * *}$ & $-1.404 * * *$ & $-1.253^{* * *}$ & $-1.116^{* * *}$ & $-1.316^{* * *}$ \\
\hline & $(0.081)$ & $(0.143)$ & $(0.184)$ & $(0.253)$ & $(0.305)$ & $(0.386)$ \\
\hline \multirow[t]{2}{*}{ ATE-AIPW Low } & $-0.664 * * *$ & * $-0.576^{* * *}$ & -0.265 & $-0.561^{* *}$ & $-1.240^{* * *}$ & $-1.731^{* * *}$ \\
\hline & $(0.076)$ & $(0.119)$ & $(0.177)$ & $(0.249)$ & $(0.292)$ & $(0.339)$ \\
\hline P-value High=Low & 0.611 & 0.010 & 0.000 & 0.000 & 0.597 & 0.150 \\
\hline Avg.(trade) in countries above cutoff & 0.867 & 1.724 & 2.699 & 3.740 & 4.611 & 5.588 \\
\hline Avg.(trade) in countries below cutoff & 0.778 & 1.566 & 2.441 & 3.364 & 4.342 & 5.424 \\
\hline Observations & 710 & 710 & 710 & 710 & 710 & 710 \\
\hline \# of Crises & 19 & 19 & 19 & 19 & 19 & 19 \\
\hline Cutoff of channel variable, median & -2.626 & -2.626 & -2.626 & -2.626 & -2.626 & -2.626 \\
\hline
\end{tabular}

\begin{tabular}{|c|c|c|c|c|c|c|}
\hline \multicolumn{7}{|c|}{ Panel II: Imports (\% of pre-crisis GDP) } \\
\hline & (1) & (2) & (3) & (4) & (5) & (6) \\
\hline & $\mathrm{h}=\mathbf{0}$ & $\mathrm{h}=\mathbf{1}$ & $\mathrm{h}=\mathbf{2}$ & $\mathrm{h}=\mathbf{3}$ & $h=4$ & $\mathrm{~h}=5$ \\
\hline \multirow{2}{*}{\multicolumn{7}{|c|}{ Panel C: Currency crises }} \\
\hline \multicolumn{5}{|l|}{ Panel a: Total } & & \\
\hline ATE-AIPW High & $\begin{array}{c}-4.368 * * * \\
(0.407)\end{array}$ & $\begin{array}{c}-5.522 * * * \\
(0.564)\end{array}$ & $\begin{array}{c}-6.105 * * * \\
(0.777)\end{array}$ & $\begin{array}{c}-8.160^{* * *} \\
(0.995)\end{array}$ & $\begin{array}{c}-8.572 * * * * \\
(1.220)\end{array}$ & $\begin{array}{c}-5.926 * * * \\
(1.575)\end{array}$ \\
\hline ATE-AIPW Low & $-5.811 * * *$ & $-8.841^{* * *}$ & $-11.575^{* * *}$ & $-11.655 * * *$ & $-11.432^{* * *}$ & $-11.809 * * *$ \\
\hline & $(0.409)$ & $(0.576)$ & $(0.806)$ & $(1.002)$ & $(1.210)$ & $(1.376)$ \\
\hline value High=Low & 0.000 & 0.000 & 0.000 & 0.000 & 0.000 & 0.000 \\
\hline & 3.939 & 8.0 & 12.409 & 17.110 & 21.235 & 25.790 \\
\hline Avg.(trade) in countries below & 3.320 & 6.673 & 10.222 & 14.087 & 18.213 & 22.447 \\
\hline
\end{tabular}

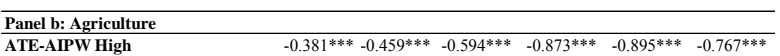
$\begin{array}{lllllll} & (0.079) & (0.070) & (0.093) & (0.107) & (0.135) & (0.169) \\ \text { ATE-AIPW Low } & -0.544^{* * *} & 0.854^{* * *} & -1.154^{* * *} & -1.208 * * * & 0.917 * * * & -0.831 * *\end{array}$ \begin{tabular}{lcccccc} 
& $-0.544^{* * *}$ & $-0.854^{* * *}$ & $-1.154^{* * *}$ & $-1.208^{* * *}$ & $-0.917 * * *$ & $-0.831 * *$ \\
\hline P-value High=Low & $(0.080)$ & $(0.074)$ & $(0.098)$ & $(0.111)$ & $(0.138)$ & $(0.151)$ \\
\hline
\end{tabular} \begin{tabular}{lllllll}
\hline P-value High=Low & 0.000 & 0.000 & 0.000 & 0.000 & 0.726 & 0.578
\end{tabular} \begin{tabular}{lllllll} 
Avg.(rade) in countries above cutof & 0.306 & 0.647 & 1.007 & 1.406 & 1.772 & 2.157 \\
\hline
\end{tabular} \begin{tabular}{lllllll} 
Avg.(trade) in countries below cutoff & 0.349 & 0.697 & 1.063 & 1.482 & 1.916 & 2.379 \\
\hline
\end{tabular}

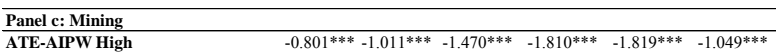
$\begin{array}{lllllll} & (0.076) & (0.130) & (0.167) & (0.221) & (0.260) & (0.352) \\ \text { ATE-AIPW Low } & -0.952 * * * & -1.519 * * * & -2.599 * * * & -3.016 * * * & -3.626 * * * & -3.725 * * *\end{array}$ \begin{tabular}{lcccccc} 
& $(0.093)$ & $(0.138)$ & $(0.180)$ & $(0.211)$ & $(0.250)$ & $(0.279)$ \\
\hline P-value High=Low & 0.018 & 0.000 & 0.000 & 0.000 & 0.000 & 0.000
\end{tabular} \begin{tabular}{lllllll} 
Avg.(trade) in countries above cutoff & 0.750 & 1.581 & 2.385 & 3.265 & 4.025 & 4.842 \\
\hline
\end{tabular} \begin{tabular}{lllllll} 
Avg.(trade) in countries below cutoff & 0.468 & 0.958 & 1.568 & 2.199 & 2.758 & 3.282 \\
\hline
\end{tabular}

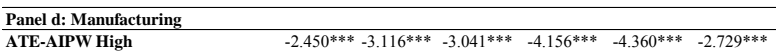
$\begin{array}{lllllll} & (0.251) & (0.340) & (0.458) & (0.590) & (0.726) & (0.913) \\ \text { ATE-AIPW Low } & -3.53 * * 253) & -5.18357 * & -6.357 * & -5.939 * & -5.735^{* * *} & -5.962 * * *\end{array}$ \begin{tabular}{cccccc}
$-3.538^{* * * *}$ & $-5.188^{* * * *}$ & $-6.357^{* * *}$ & $-5.939 * * *$ & $-5.735^{* * *}$ & $-5.962^{* * *}$ \\
$(0.253)$ & $(0.357)$ & $(0.480)$ & $(0.596)$ & $(0.720)$ & $(0.826)$ \\
\hline
\end{tabular} \begin{tabular}{lcccccc}
\hline P-value High=Low & 0.000 & 0.000 & 0.000 & 0.000 & 0.000 & 0.000 \\
\hline
\end{tabular} \begin{tabular}{llllllll} 
Avg.(trade) in countries blow cutoff & 1.910 & 3.831 & 5.784 & 7.574 & 11.889 & 14.544 \\
\hline
\end{tabular} \begin{tabular}{llllll}
\hline Panel e: Services & & & \\
\hline ATE
\end{tabular}

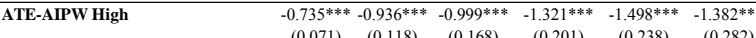
$\begin{array}{llllll}\text { ATE-AIPW Low } \quad-0.777 * * * & -1.281 * * * & -1.465^{* * *} & -1.492 * * * & -1.155^{* * *} & -1.291 * * *\end{array}$ \begin{tabular}{lllllll} 
& $(0.075)$ & $(0.116)$ & $(0.168)$ & $(0.207)$ & $(0.241)$ & $(0.270)$ \\
\hline
\end{tabular}

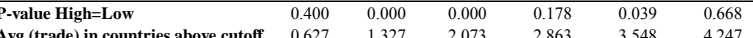
\begin{tabular}{lllllll} 
Avg (tre & 0.178 & 0.039 & 0.668 \\
\hline
\end{tabular} \begin{tabular}{lcccccc} 
Avg.(trade) in countries below cutoff & 0.593 & 1.187 & 1.807 & 2.561 & 3.317 & 4.132 \\
\hline Observations & 710 & 710 & 710 & 710 & 710 & 710
\end{tabular} \# of Crises \begin{tabular}{cccccc}
19 & 19 & 19 & 19 & 19 & 19 \\
-2.626 & -2.626 & -2.626 & -2.626 & -2.626 & -2.626 \\
\hline
\end{tabular}

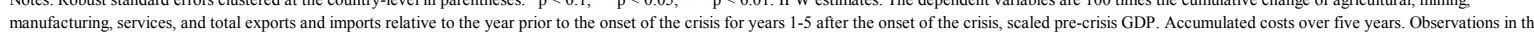
mantact 
Table A.17a: Channels, Cumulative trade losses over five years after debt crises with higher and lower partners' diversification

\begin{tabular}{|c|c|c|c|c|c|c|}
\hline \multicolumn{7}{|c|}{ Panel I: Exports (\% of pre-crisis GDP) } \\
\hline & (1) & (2) & (3) & (4) & (5) & (6) \\
\hline & $\mathbf{h}=\mathbf{0}$ & $\mathrm{h}=1$ & $\mathrm{~h}=\mathbf{2}$ & $h=3$ & $h=4$ & $h=5$ \\
\hline \multicolumn{7}{|c|}{ Panel A: Debt crises } \\
\hline \multicolumn{7}{|l|}{ Panel a: Total } \\
\hline ATE-AIPW High & $\begin{array}{c}-2.122 * * * \\
(0.273)\end{array}$ & $\begin{array}{c}-2.932 * * * \\
(0.438)\end{array}$ & $\begin{array}{c}-3.205 * * * \\
(0.601)\end{array}$ & $\begin{array}{c}-5.505 * * * \\
(0.786)\end{array}$ & $\begin{array}{c}-5.963 * * * \\
(0.995)\end{array}$ & $\begin{array}{c}-5.571^{* * *} \\
(1.371)\end{array}$ \\
\hline \multirow[t]{2}{*}{ ATE-AIPW Low } & $-0.819^{* * *}$ & $-3.430^{* * * *}$ & $-5.488 * * *$ & $-8.469 * * *$ & $-10.352 * * *$ & $*-11.499 * * *$ \\
\hline & $(0.316)$ & $(0.414)$ & $(0.580)$ & $(0.824)$ & $(0.995)$ & $(1.342)$ \\
\hline P-value High=Low & 0.000 & 0.067 & 0.000 & 0.000 & 0.000 & 0.000 \\
\hline Avg.(trade) in countries above cutoff & 3.408 & 6.906 & 10.623 & 14.548 & 18.010 & 21.646 \\
\hline Avg.(trade) in countries below cutoff & 2.498 & 5.122 & 8.162 & 11.422 & 14.550 & 18.278 \\
\hline \multicolumn{7}{|l|}{$\overline{\text { Panel b: Agriculture }}$} \\
\hline ATE-AIPW High & $\begin{array}{c}-0.649^{* * * *} \\
(0.111)\end{array}$ & $\begin{array}{c}-0.394 * * * \\
(0.108)\end{array}$ & $\begin{array}{c}-0.022 \\
(0.172)\end{array}$ & $\begin{array}{l}-0.332^{*} \\
(0.199)\end{array}$ & $\begin{array}{c}-0.348 \\
(0.247)\end{array}$ & $\begin{array}{c}0.410 \\
(0.320)\end{array}$ \\
\hline ATE-AIPW Low & $\begin{array}{c}-0.244 * * * \\
(0.079)\end{array}$ & $\begin{array}{l}-0.056 \\
(0.097)\end{array}$ & $\begin{array}{l}-0.096 \\
(0.151)\end{array}$ & $\begin{array}{l}0.609 * * \\
(0.269)\end{array}$ & $\begin{array}{c}-0.027 \\
(0.280)\end{array}$ & $\begin{array}{l}-0.019 \\
(0.278)\end{array}$ \\
\hline P-value High=Low & 0.000 & 0.000 & 0.591 & 0.000 & 0.216 & 0.150 \\
\hline Avg.(trade) in countries above cutoff & 0.444 & 0.926 & 1.461 & 2.018 & 2.498 & 3.046 \\
\hline Avg.(trade) in countries below cutoff & 0.302 & 0.606 & 0.981 & 1.390 & 1.740 & 2.210 \\
\hline \multicolumn{7}{|l|}{ Panel c: Mining } \\
\hline ATE-AIPW High & $\begin{array}{c}-0.426^{* * *} \\
(0.110)\end{array}$ & $\begin{array}{c}-0.435^{* *} \\
(0.175)\end{array}$ & $\begin{array}{c}-0.686^{* * * *} \\
(0.230)\end{array}$ & $\begin{array}{c}-0.990^{* * * *} \\
(0.304)\end{array}$ & $\begin{array}{c}-1.016^{* * *} \\
(0.392)\end{array}$ & $\begin{array}{c}-1.037^{* *} \\
(0.472)\end{array}$ \\
\hline ATE-AIPW Low & $\begin{array}{c}0.847 * * * \\
(0.197)\end{array}$ & 0.348 & -0.234 & $\begin{array}{c}-1.860^{* * * *} \\
(0.350)\end{array}$ & $\begin{array}{c}-1.028^{* *} \\
(0.413)\end{array}$ & $\begin{array}{l}-0.022 \\
(0.580)\end{array}$ \\
\hline P-value High=Low & 0.000 & 0.000 & 0.004 & $\frac{(0.5000}{0.000}$ & $\frac{0.413)}{0.964}$ & $\frac{(0.580)}{0.021}$ \\
\hline Avg.(trade) in countries above cutoff & 0.573 & 1.149 & 1.764 & 2.415 & 2.977 & 3.436 \\
\hline Avg.(trade) in countries below cutoff & 0.449 & 0.942 & 1.530 & 2.164 & 2.706 & 3.387 \\
\hline \multicolumn{7}{|l|}{ Panel d: Manufacturing } \\
\hline ATE-AIPW High & $\begin{array}{c}-0.703 * * * \\
(0.147)\end{array}$ & $\begin{array}{c}-1.007 * * * \\
(0.253)\end{array}$ & $\begin{array}{c}-1.654 * * * \\
(0.326)\end{array}$ & $\begin{array}{c}-2.928 * * * \\
(0.418)\end{array}$ & $\begin{array}{c}-3.255^{* * *} \\
(0.542)\end{array}$ & $\begin{array}{c}-3.510^{* * *} \\
(0.739)\end{array}$ \\
\hline \multirow[t]{2}{*}{ ATE-AIPW Low } & $-0.944 * * *$ & $-2.327^{* * *}$ & $-3.363 * * *$ & $-4.899 * * *$ & $-6.421 * * *$ & $-7.584^{* * *}$ \\
\hline & $(0.137)$ & $(0.224)$ & $(0.318)$ & $(0.412)$ & $(0.536)$ & $(0.732)$ \\
\hline P-value High=Low & 0.000 & 0.000 & 0.000 & 0.000 & 0.000 & 0.000 \\
\hline Avg.(trade) in countries above cutoff & 1.506 & 3.075 & 4.661 & 6.321 & 7.771 & 9.344 \\
\hline Avg.(trade) in countries below cutoff & 1.010 & 2.072 & 3.309 & 4.654 & 6.009 & 7.602 \\
\hline \multicolumn{7}{|l|}{ Panel e: Services } \\
\hline ATE-AIPW High & $\begin{array}{c}-0.344^{* * *} \\
(0.081)\end{array}$ & $\begin{array}{c}-1.096^{* * * *} \\
(0.134)\end{array}$ & $\begin{array}{c}-0.844^{* * * *} \\
(0.194)\end{array}$ & $\begin{array}{c}-1.256^{* * * *} \\
(0.247)\end{array}$ & $\begin{array}{c}-1.344^{* * *} \\
(0.296)\end{array}$ & $\begin{array}{c}-1.435^{* * *} \\
(0.379)\end{array}$ \\
\hline \multirow[t]{2}{*}{ ATE-AIPW Low } & $-0.479 * * *$ & $-1.394 * * *$ & $-1.794 * * *$ & $-2.318 * * *$ & $-2.876 * * *$ & $-3.874 * * *$ \\
\hline & $(0.078)$ & $(0.131)$ & $(0.188)$ & $(0.244)$ & $(0.290)$ & $(0.377)$ \\
\hline P-value High=Low & 0.001 & 0.000 & 0.000 & 0.000 & 0.000 & 0.000 \\
\hline Avg.(trade) in countries above cutoff & 0.885 & 1.756 & 2.737 & 3.794 & 4.764 & 5.820 \\
\hline Avg.(trade) in countries below cutoff & 0.737 & 1.502 & 2.343 & 3.214 & 4.096 & 5.079 \\
\hline Observations & 708 & 708 & 708 & 708 & 708 & 708 \\
\hline \# of Crises & 20 & 20 & 20 & 20 & 20 & 20 \\
\hline Cutoff of channel variable, median & -2.647 & -2.647 & -2.647 & -2.647 & -2.647 & -2.647 \\
\hline
\end{tabular}

\begin{tabular}{|c|c|c|c|c|c|c|}
\hline \multirow{2}{*}{\multicolumn{7}{|c|}{ Panel II: Imports (\% of pre-crisis GDP) }} \\
\hline & & & & (4) & (5) & (6) \\
\hline & $\mathrm{h}=\mathbf{0}$ & $\mathrm{h}=1$ & $\mathrm{~h}=2$ & $h=3$ & $h=4$ & $h=5$ \\
\hline \multicolumn{7}{|c|}{ Panel A: Debt crises } \\
\hline \multicolumn{7}{|l|}{ Panel a: Total } \\
\hline ATE-AIPW High & $\begin{array}{c}-3.793 * * * \\
(0.390)\end{array}$ & $\begin{array}{c}-6.716^{* * * *} \\
(0.594)\end{array}$ & $\begin{array}{c}-7.603 * * * \\
(0.894)\end{array}$ & $\begin{array}{c}-8.189^{* * * *} \\
(1.086)\end{array}$ & $\begin{array}{c}-9.440 * * * \\
(1.382)\end{array}$ & $\begin{array}{c}-10.110^{* * * *} \\
(1.759)\end{array}$ \\
\hline ATE-AIPW Low & $\begin{array}{c}-3.227 * * * \\
(0.452)\end{array}$ & $\begin{array}{c}-5.393 * * * \\
(0.647)\end{array}$ & $\begin{array}{c}-6.527 * * * \\
(0.941)\end{array}$ & $\begin{array}{c}-9.592 * * * \\
(1.095)\end{array}$ & $\begin{array}{c}-11.627^{* * *} \\
(1397)\end{array}$ & $=-12.841^{* * *}$ \\
\hline alue & 0.074 & 0.001 & 0.034 & 0.017 & 0.001 & 0.002 \\
\hline g.(trade) in countries & 3.969 & 7.939 & 12.020 & 16.432 & 20.518 & 24.673 \\
\hline Avg.(trade) in countries below cutoff & 3.157 & 6.540 & 10.233 & 14.240 & 18.398 & 22.999 \\
\hline
\end{tabular}

\begin{tabular}{|c|}
\hline $\begin{array}{l}\text { Panel b: Agriculture } \\
\text { ATE-AIPW High }\end{array}$ \\
\hline
\end{tabular}

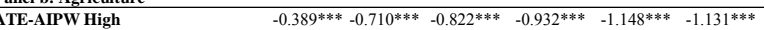
$\begin{array}{lllllll} & (0.073) & (0.076) & (0.124) & (0.121) & (0.162) & (0.187) \\ \text { ATE-AIPW Low } & -0.017 & -0.464 * * * & -0.535 * * * & -0.966 * * * & -1.402 * * * & -1.110^{* * *}\end{array}$ \begin{tabular}{ccccccc} 
& -0.017 & $-0.464^{* * *}$ & $-0.535^{* *}$ & $-0.966^{* * *}$ & $-1.402^{* * *}$ & $-1.110^{* * *}$ \\
& $(0.064)$ & $(0.077)$ & $(0.125)$ & $(0.125)$ & $(0.161)$ & $(0.183)$ \\
\hline
\end{tabular} \begin{tabular}{lllllll}
\hline P-value High=Low & 0.000 & 0.000 & 0.000 & 0.594 & 0.000 & 0.816
\end{tabular} \begin{tabular}{lllllll} 
Avg.(trade) in countries above cutoff & 0.330 & 0.700 & 1.079 & 1.493 & 1.899 & 2.306 \\
Avg.(trade) in countries below cutoff & 0.334 & 0.654 & 1.001 & 1.406 & 1.807 & 2.265 \\
\hline
\end{tabular} \begin{tabular}{llllllll} 
Avg.(trade) in countries below cutoff & 0.334 & 0.654 & 1.001 & 1.406 & 1.807 & 2.265 \\
\hline & & & &
\end{tabular}

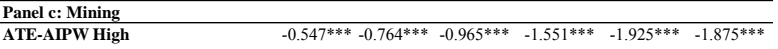
$\begin{array}{lcccccc} & (0.092) & (0.148) & (0.198) & (0.278) & (0.350) & (0.474) \\ \text { ATE-AIPW Low } & -0.432 * * * & -0.697 * * * & -1.030 * * * & -1.900 * * * & -1.903 * * * & -2.524 * * *\end{array}$ \begin{tabular}{lcccccc} 
& $(0.088)$ & $(0.165)$ & $(0.207)$ & $(0.256)$ & $(0.316)$ & $(0.397)$ \\
\hline P-value High=Low & 0.055 & 0.603 & 0.669 & 0.076 & 0.906 & 0.027
\end{tabular} \begin{tabular}{lllllll} 
Avg.(trade) in countries above cutoff & 0.700 & 1.425 & 2.161 & 2.955 & 3.563 & 4.132 \\
\hline
\end{tabular} \begin{tabular}{lllllll} 
Avg.(trade) in countries below cutoff & 0.466 & 1.001 & 1.643 & 2.316 & 3.000 & 3.739 \\
\hline
\end{tabular}

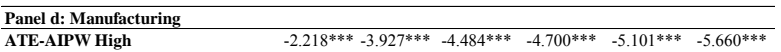
$\begin{array}{lllllll} & (0.244) & (0.364) & (0.537) & (0.624) & (0.789) & (0.968) \\ \text { ATE-AIPW Low } & -1.83 * * & -3.033 * * & -3.060^{* * *} & 4.431^{* * *} & -6.093^{* * *} & -6.815 * * *\end{array}$

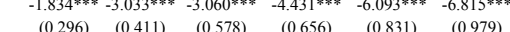
\begin{tabular}{lcccccc}
\hline P-value High=Low & 0.057 & 0.000 & 0.000 & 0.435 & 0.019 & 0.013 \\
& & 0.007 &
\end{tabular} \begin{tabular}{lllllll} 
Avg.(trade) in countries above culf & 2.297 & 4.536 & 6.786 & 9.185 & 11.553 & 13.961 \\
\hline
\end{tabular} \begin{tabular}{lllllll} 
Avg.(trade) in countries below cutoff & 1.788 & 3.670 & 5.742 & 7.941 & 10.269 & 12.914 \\
\hline
\end{tabular}

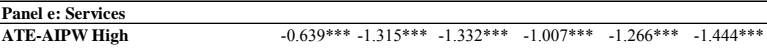
$\begin{array}{lllllll} & (0.090) & (0.129) & (0.170) & (0.201) & (0.240) & (0.305)\end{array}$

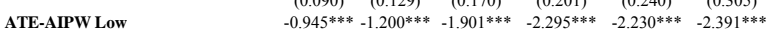
\begin{tabular}{lcccccc} 
& $(0.103)$ & $(0.143)$ & $(0.199)$ & $(0.227)$ & $(0.275)$ & $(0.323)$ \\
\hline P-value High=Low & 0.000 & 0.277 & 0.000 & 0.000 & 0.000 & 0.000
\end{tabular}

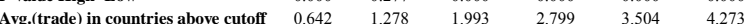

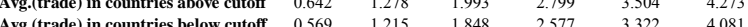
\begin{tabular}{lcccccc} 
Avg.(trade) in countries below cutoff & 0.569 & 1.215 & 1.848 & 2.577 & 3.322 & 4.081 \\
\hline Observations & 708 & 708 & 708 & 708 & 708 & 708
\end{tabular}

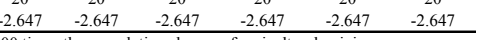
Notes: Robust standard errors clustered at the country-level in parentheses. ${ }^{*} p<0.1,{ }^{*} \mathrm{p}<0.05,{ }^{*} \mathrm{p}<<0.01$. IPW estimates. The dependent $v$

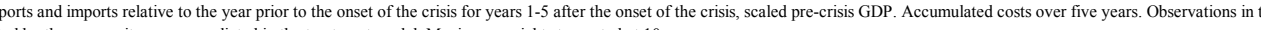
treated and control groups are weighted by the propensity scores predicted in the treatment model. Maximum weights truncated at 10 . 
Table A.17b: Channels, Cumulative trade losses over five years after banking crises with higher and lower partners' diversification

\begin{tabular}{|c|c|c|c|c|c|c|}
\hline \multicolumn{7}{|c|}{ Panel I: Exports (\% of pre-crisis GDP) } \\
\hline & (1) & (2) & (3) & (4) & (5) & (6) \\
\hline & $\mathbf{h}=\mathbf{0}$ & $\mathrm{h}=1$ & $\mathrm{~h}=2$ & $h=3$ & $h=4$ & $h=5$ \\
\hline \multicolumn{7}{|c|}{ Panel B: Banking crises } \\
\hline \multicolumn{7}{|l|}{ Panel a: Total } \\
\hline ATE-AIPW High & $\begin{array}{c}-0.586 \\
(0.368)\end{array}$ & $\begin{array}{c}-6.705^{* * *} \\
(0.512)\end{array}$ & $\begin{array}{c}*-6.833 * * * \\
(0.619)\end{array}$ & $\begin{array}{c}-5.696^{* * *} \\
(0.758)\end{array}$ & $\begin{array}{c}-8.003^{* * *} * \\
(0.998)\end{array}$ & $\begin{array}{c}-9.403 * * * \\
(1.131)\end{array}$ \\
\hline \multirow[t]{2}{*}{ ATE-AIPW Low } & $-1.773 * * *$ & * $-3.846^{* * * *}$ & * $-4.900 * * *$ & $-5.836 * * *$ & $-9.015 * * *$ & $-9.904 * * *$ \\
\hline & $(0.291)$ & $(0.501)$ & $(0.643)$ & $(0.781)$ & $(1.028)$ & $(1.149)$ \\
\hline P-value High=Low & 0.000 & 0.000 & 0.000 & 0.729 & 0.042 & 0.349 \\
\hline Avg.(trade) in countries above cutoff & 3.323 & 6.806 & 10.544 & 14.475 & 17.794 & 21.415 \\
\hline Avg.(trade) in countries below cutoff & 2.673 & 5.405 & 8.500 & 11.824 & 15.120 & 18.851 \\
\hline \multicolumn{7}{|l|}{ Panel b: Agriculture } \\
\hline ATE-AIPW High & $\begin{array}{l}-0.019 \\
(0.072)\end{array}$ & $\begin{array}{c}-0.399^{* * *} \\
(0.091)\end{array}$ & $\begin{array}{c}-0.554^{* * *} \\
(0.116)\end{array}$ & $\begin{array}{c}-0.498^{* * *} \\
(0.149)\end{array}$ & $\begin{array}{c}-0.336^{*} \\
(0.189)\end{array}$ & $\begin{array}{c}-0.554^{* * *} \\
(0.211)\end{array}$ \\
\hline ATE-AIPW Low & $\begin{array}{c}-0.082 \\
(0.065)\end{array}$ & $\begin{array}{c}-0.554^{* * * *} \\
(0.095)\end{array}$ & $\begin{array}{c}-0.954 * * * \\
(0.128)\end{array}$ & $\begin{array}{c}-1.190^{* * *} \\
(0.148)\end{array}$ & $\begin{array}{c}-1.580^{* * * *} \\
(0.161)\end{array}$ & $\begin{array}{c}-2.190^{* * *} \\
(0.176)\end{array}$ \\
\hline$\overline{P \text {-value High=Low }}$ & 0.312 & 0.029 & 0.000 & 0.000 & 0.000 & 0.000 \\
\hline Avg.(trade) in countries above cutoff & 0.444 & 0.938 & 1.496 & 2.055 & 2.533 & 3.077 \\
\hline Avg.(trade) in countries below cutoff & 0.317 & 0.630 & 1.000 & 1.423 & 1.790 & 2.272 \\
\hline \multicolumn{7}{|l|}{ Panel c: Mining } \\
\hline ATE-AIPW High & $\begin{array}{c}0.063 \\
(0.180)\end{array}$ & $\begin{array}{c}-1.384^{* * * *} \\
(0.260)\end{array}$ & $\begin{array}{c}-1.377^{* * * *} \\
(0.291)\end{array}$ & $\begin{array}{c}-1.277^{* * *} \\
(0.318)\end{array}$ & $\begin{array}{c}-1.906^{* * * *} \\
(0.381)\end{array}$ & $\begin{array}{c}-2.307 * * * \\
(0.470)\end{array}$ \\
\hline ATE-AIPW Low & $\begin{array}{c}-0.486^{* * *} \\
(0.162)\end{array}$ & $\begin{array}{c}-0.624^{* *} \\
(0.266)\end{array}$ & $\begin{array}{c}-0.639 * * \\
(0.310)\end{array}$ & $\begin{array}{c}-1.407 * * * \\
(0.312)\end{array}$ & $\begin{array}{c}-2.674 * * * \\
(0.357)\end{array}$ & $\begin{array}{c}-1.556^{* * *} \\
(0.507)\end{array}$ \\
\hline$\overline{P \text {-value High=Low }}$ & 0.000 & 0.000 & 0.000 & 0.415 & 0.000 & 0.006 \\
\hline Avg.(trade) in countries above cutoff & 0.536 & 1.112 & 1.726 & 2.360 & 2.898 & 3.336 \\
\hline Avg.(trade) in countries below cutoff & 0.496 & 0.998 & 1.590 & 2.241 & 2.806 & 3.482 \\
\hline \multicolumn{7}{|l|}{ Panel d: Manufacturing } \\
\hline ATE-AIPW High & $\begin{array}{c}0.023 \\
(0.177)\end{array}$ & $\begin{array}{c}-2.973 * * * \\
(0.273)\end{array}$ & $\begin{array}{c}-2.611^{* * *} \\
(0.325)\end{array}$ & $\begin{array}{c}-1.537^{* * *} \\
(0.439)\end{array}$ & $\begin{array}{c}-2.704 * * * \\
(0.564)\end{array}$ & $\begin{array}{c}-3.280^{* * *} \\
(0.647)\end{array}$ \\
\hline ATE-AIPW Low & $\begin{array}{c}-0.648^{* * *} \\
(0.147)\end{array}$ & $\begin{array}{c}{ }^{*}-0.985 * * * \\
(0.269)\end{array}$ & $\begin{array}{c}-1.147 * * * \\
(0.390)\end{array}$ & $\begin{array}{c}-1.138^{* *} \\
(0.493)\end{array}$ & $\begin{array}{c}-1.613^{* * *} \\
(0.598)\end{array}$ & $\begin{array}{c}-1.748^{* *} \\
(0.705)\end{array}$ \\
\hline$\overline{\text { P-value High=Low }}$ & 0.000 & 0.000 & 0.000 & 0.255 & 0.004 & 0.002 \\
\hline Avg.(trade) in countries above cutoff & 1.461 & 2.954 & 4.508 & 6.153 & 7.485 & 9.038 \\
\hline Avg.(trade) in countries below cutoff & 1.104 & 2.290 & 3.594 & 4.986 & 6.458 & 8.068 \\
\hline \multicolumn{7}{|l|}{ Panel e: Services } \\
\hline ATE-AIPW High & $\begin{array}{c}-0.652^{* * *} * \\
(0.102)\end{array}$ & $\begin{array}{c}*-1.949^{* * * *} \\
(0.147)\end{array}$ & $\begin{array}{c}-2.290^{* * *} \\
(0.208)\end{array}$ & $\begin{array}{c}-2.384^{* * *} \\
(0.285)\end{array}$ & $\begin{array}{c}-3.057^{* * *} * \\
(0.388)\end{array}$ & $\begin{array}{c}-3.262^{* * *} \\
(0.437)\end{array}$ \\
\hline \multirow[t]{2}{*}{ ATE-AIPW Low } & $-0.556 * * *$ & $-1.683^{* * *}$ & $-2.160^{* * *}$ & $-2.100^{* * *}$ & $-3.149 * * *$ & $-4.409 * * *$ \\
\hline & $(0.097)$ & $(0.167)$ & $(0.250)$ & $(0.338)$ & $(0.435)$ & $(0.468)$ \\
\hline P-value High=Low & 0.275 & 0.019 & 0.413 & 0.181 & 0.687 & 0.000 \\
\hline Avg.(trade) in countries above cutoff & 0.882 & 1.802 & 2.813 & 3.906 & 4.878 & 5.964 \\
\hline Avg.(trade) in countries below cutoff & 0.756 & 1.488 & 2.316 & 3.174 & 4.065 & 5.029 \\
\hline Observations & 710 & 710 & 710 & 710 & 710 & 710 \\
\hline$\#$ of Crises & 18 & 18 & 18 & 18 & 18 & 18 \\
\hline Cutoff of channel variable, median & -2.570 & -2.570 & -2.570 & -2.570 & -2.570 & -2.570 \\
\hline
\end{tabular}

\begin{tabular}{|c|c|c|c|c|c|c|}
\hline \multirow{2}{*}{\multicolumn{7}{|c|}{$\begin{array}{l}\text { Panel II: Imports (\% of pre-crisis GDP) } \\
\text { (1) }\end{array}$}} \\
\hline & (1) & (2) & (3) & (4) & (5) & (6) \\
\hline & $\mathrm{h}=\mathbf{0}$ & $\mathrm{h}=1$ & $h=2$ & $\mathrm{~h}=\mathbf{3}$ & $h=4$ & $h=5$ \\
\hline \multicolumn{7}{|c|}{ Panel B: Banking crises } \\
\hline \multicolumn{7}{|l|}{ Panel a: Total } \\
\hline ATE-AIPW High & $\begin{array}{c}-3.632 * * * \\
(0.539)\end{array}$ & $\begin{array}{c}-11.387 * * * \\
(0.817)\end{array}$ & $\begin{array}{c}-11.124 * * * \\
(0.987)\end{array}$ & $\begin{array}{c}-9.891^{* * * *} \\
(1.209)\end{array}$ & $\begin{array}{c}-12.012^{* * *} \\
(1.599)\end{array}$ & $\begin{array}{c}-13.812 * * * \\
(1.633)\end{array}$ \\
\hline ATE-AIPW Low & $\begin{array}{c}-1.576 * * * \\
(0.421)\end{array}$ & $\begin{array}{c}-5.140^{* * *} \\
(0.774)\end{array}$ & $\begin{array}{c}-7.882 * * * \\
(0.990)\end{array}$ & $\begin{array}{c}-9.455^{* * * *} \\
(1.216)\end{array}$ & $-11.356 * * *$ & $\begin{array}{c}-14.855^{* * * *} \\
(1.665)\end{array}$ \\
\hline alue & 0.000 & 0.000 & 0.000 & 0.377 & 0.372 & 0.197 \\
\hline de) in countri & 3.740 & 7.721 & 11.8 & 16.362 & 20.229 & 24.397 \\
\hline Avg.(trade) in countries below cutoff & 3.452 & 6.888 & 10.586 & 14.539 & 18.889 & 23.430 \\
\hline
\end{tabular}

\begin{tabular}{llllll}
\hline Panel b: Agriculture & \multicolumn{5}{l}{} \\
\hline ATE-AIPW High & $-0.419^{* * *}-0.598^{* * * *}$ & $-0.684^{* * *}$ & $-0.866^{* * * *}$ & $-1.156^{* * *}$ & $-1.193 * * *$
\end{tabular}

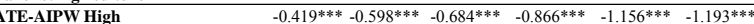
$\begin{array}{llllllc} & (0.065) & (0.086) & (0.105) & (0.140) & (0.211) & (0.200) \\ \text { ATE-AIPW Low } & -0.012 & 0.248^{* *} & -0.116 & -0.481^{* * *} & -0.732 * * * & -1.598 * * *\end{array}$

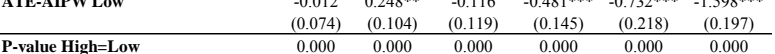
\begin{tabular}{lllllll} 
Avg.(trade) in countries above cutoff & 0.000 & 0.000 & 0.000 & 0.000 & 0.000 & 0.000 \\
& 0.311 & 0.683 & 1.074 & 1.510 & 1.902 & 2.313 \\
\hline
\end{tabular} \begin{tabular}{lllllll} 
Avg.(trade) in countries below cutoff & 0.351 & 0.675 & 1.014 & 1.400 & 1.813 & 2.263 \\
\hline
\end{tabular}

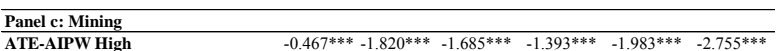

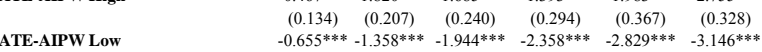
\begin{tabular}{lcccccc} 
& $(0.108)$ & $(0.203)$ & $(0.240)$ & $(0.273)$ & $(0.355)$ & $(0.322)$ \\
\hline P-value High=Low & 0.029 & 0.000 & 0.000 & 0.000 & 0.000 & 0.001
\end{tabular} $\begin{array}{lllllll}\text { Avg.(trade) in countries above cutoff } & 0.695 & 1.446 & 2.222 & 3.046 & 3.611 & 4.210 \\ \text { P. } & & & \end{array}$ Avg.(trade) in countries below cutoff

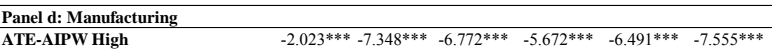
\begin{tabular}{lllllll} 
& $(0.300)$ & $(0.473)$ & $(0.557)$ & $(0.657)$ & $(0.851)$ & $(0.941)$ \\
\hline
\end{tabular}

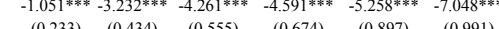
\begin{tabular}{lcccccc}
\hline P-value High=Low & 0.000 & 0.000 & 0.000 & 0.001 & 0.020 & 0.402 \\
\hline
\end{tabular} \begin{tabular}{lllllll} 
Avg.(trade) in countries above cutoff & 2.119 & 4.316 & 6.547 & 8.991 & 11.217 & 13.583 \\
\hline
\end{tabular} \begin{tabular}{lllllll} 
Avg.(trade) in countries below cutoff & 2.004 & 3.963 & 6.071 & 8.251 & 10.712 & 13.371 \\
\hline
\end{tabular}

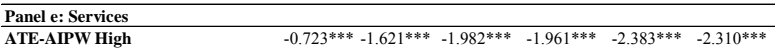

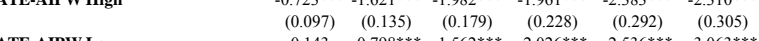
ATE-AIPW Low $\quad \begin{array}{llllll}0.143 & -0.798^{* * *} & -1.562 * * * & -2.026 * * * & -2.536^{* * *} & -3.063 * * *\end{array}$ \begin{tabular}{lcccccc}
\hline P-value High=Low & $(0.088)$ & $(0.123)$ & $(0.192)$ & $(0.246)$ & $(0.302)$ & $(0.315)$ \\
\hline
\end{tabular} $\begin{array}{lllllll}\text { Avg.(trade) in countries above cutoff } & 0.614 & 1.277 & 2.000 & 2.816 & 3.499 & 4.001\end{array}$

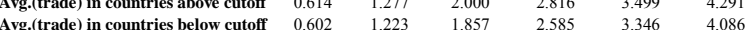
\begin{tabular}{lccccccc} 
Avg.(trade) in countries below cutoff & 0.602 & 1.223 & 1.857 & 2.585 & 3.346 & 4.086 \\
\hline Observations & 710 & 710 & 710 & 710 & 710 & 710
\end{tabular} \# of Crises
Cutoff of channel variable, median \begin{tabular}{cccccc}
18 & 18 & 18 & 18 & 18 & 18 \\
-2.570 & -2.570 & -2.570 & -2.570 & -2.570 & -2.570 \\
\hline
\end{tabular} Notes: Robust standard errors clustered at the country-level in parentheses. ${ }^{*} \mathrm{p}<0.1, * * \mathrm{p}<0.05,{ }^{* * *} \mathrm{p}<0.01$. IPW estimates. The dependent variables are 100 times the cumulative change of agricultural, mining,
manufacturing, services, and total exports and imports relative to the year prior to the onset of the crisis for years $1-5$ after the onset of the crisis, scaled pre-crisis GDP. Accumulated costs over five years. Observations in the manufacturing, services, and total exports and imports relative to the year prior to the onset of the crisis for years $1-5$ after the onset 0 the
treated and control groups are weighted by the propensity scores predicted in the treatment model. Maximum weights truncated at 10. 
Table A.17c: Channels, Cumulative trade losses over five years after currency crises with higher and lower partners' diversification

\begin{tabular}{|c|c|c|c|c|c|c|}
\hline \multicolumn{7}{|c|}{ Panel I: Exports (\% of pre-crisis GDP) } \\
\hline & (1) & (2) & (3) & (4) & (5) & (6) \\
\hline & $\mathrm{h}=\mathbf{0}$ & $\mathrm{h}=1$ & $\mathrm{~h}=\mathbf{2}$ & $h=3$ & $h=4$ & $\mathrm{~h}=5$ \\
\hline \multicolumn{7}{|c|}{ Panel C: Currency crises } \\
\hline \multicolumn{7}{|l|}{ Panel a: Total } \\
\hline ATE-AIPW High & $\begin{array}{c}-1.906 * * * * \\
(0.284)\end{array}$ & $\begin{array}{c}-2.691 * * * * \\
(0.390)\end{array}$ & $\begin{array}{c}-4.702 * * * \\
(0.543)\end{array}$ & $\begin{array}{c}-5.056^{* * * *} \\
(0.719)\end{array}$ & $\begin{array}{c}-4.832^{* * *} \\
(0.863)\end{array}$ & $\begin{array}{c}-3.864^{* * *} * \\
(1.180)\end{array}$ \\
\hline ATE-AIPW Low & $\begin{array}{c}-1.910^{* * * *} \\
(0.308)\end{array}$ & $\begin{array}{c}-3.838 * * * * \\
(0.422)\end{array}$ & $\begin{array}{c}-4.368 * * * \\
(0.612)\end{array}$ & $\begin{array}{c}-5.609 * * * * \\
(0.756)\end{array}$ & $\begin{array}{c}-8.273 * * * \\
(0.847)\end{array}$ & $\begin{array}{c}-9.555^{* * *} \\
(0.989)\end{array}$ \\
\hline P-value High=Low & 0.981 & 0.000 & 0.407 & 0.253 & 0.000 & 0.000 \\
\hline Avg.(trade) in countries above cutoff & 3.400 & 6.948 & 10.694 & 14.608 & 18.135 & 21.811 \\
\hline Avg.(trade) in countries below cutoff & 2.482 & 5.023 & 8.011 & 11.265 & 14.308 & 17.989 \\
\hline \multicolumn{7}{|l|}{ Panel b: Agriculture } \\
\hline ATE-AIPW High & $\begin{array}{c}-0.107 * * \\
(0.053)\end{array}$ & $\begin{array}{c}-0.426 * * * * \\
(0.087)\end{array}$ & $\begin{array}{c}-0.399 * * * \\
(0.122)\end{array}$ & $\begin{array}{l}-0.336^{*} \\
(0.172)\end{array}$ & $\begin{array}{l}-0.147 \\
(0.205)\end{array}$ & $\begin{array}{c}-0.109 \\
(0.284)\end{array}$ \\
\hline ATE-AIPW Low & $\begin{array}{c}0.237 * * * \\
(0.072)\end{array}$ & $\begin{array}{c}-0.097 \\
(0.105)\end{array}$ & $\begin{array}{c}0.306 \\
(0.214)\end{array}$ & $\begin{array}{c}-0.161 \\
(0.215)\end{array}$ & $\begin{array}{c}-0.333^{*} \\
(0.193)\end{array}$ & $\begin{array}{c}-0.437^{* *} \\
(0.223)\end{array}$ \\
\hline P-value High=Low & 0.000 & 0.001 & 0.001 & 0.407 & 0.311 & 0.214 \\
\hline Avg.(trade) in countries above cutoff & 0.437 & 0.921 & 1.452 & 2.001 & 2.481 & 3.028 \\
\hline Avg.(trade) in countries below cutoff & 0.306 & 0.604 & 0.979 & 1.393 & 1.740 & 2.209 \\
\hline \multicolumn{7}{|l|}{ Panel c: Mining } \\
\hline ATE-AIPW High & $\begin{array}{l}-0.155 \\
(0.196)\end{array}$ & $\begin{array}{c}-0.579 * * * * \\
(0.153)\end{array}$ & $\begin{array}{c}-0.968^{* * * *} \\
(0.210)\end{array}$ & $\begin{array}{c}-1.269^{* * * *} \\
(0.272)\end{array}$ & $\begin{array}{c}-1.498^{* * * *} \\
(0.323)\end{array}$ & $\begin{array}{c}-1.378^{* * *} \\
(0.392)\end{array}$ \\
\hline ATE-AIPW Low & $\begin{array}{c}-0.593 * * * * \\
(0.211)\end{array}$ & $\begin{array}{c}-1.431 * * * \\
(0.182)\end{array}$ & $\begin{array}{c}-1.805 * * * \\
(0.264)\end{array}$ & $\begin{array}{c}-2.032 * * * * \\
(0.298)\end{array}$ & $\begin{array}{c}-3.390 * * * \\
(0.324)\end{array}$ & $\begin{array}{c}-3.460^{* * *} \\
(0.377)\end{array}$ \\
\hline $\begin{array}{l}\text { P-value High=Low } \\
\end{array}$ & 0.000 & 0.000 & 0.000 & 0.000 & 0.000 & 0.000 \\
\hline Avg.(trade) in countries above cutoff & 0.564 & 1.137 & 1.755 & 2.395 & 2.958 & 3.418 \\
\hline Avg.(trade) in countries below cutoff & 0.457 & 0.950 & 1.535 & 2.182 & 2.720 & 3.407 \\
\hline \multicolumn{7}{|l|}{ Panel d: Manufacturing } \\
\hline ATE-AIPW High & $\begin{array}{c}-0.952 * * * * \\
(0.128)\end{array}$ & $\begin{array}{c}-1.044^{* * *} * \\
(0.211)\end{array}$ & $\begin{array}{c}-2.038^{* * *} \\
(0.295)\end{array}$ & $\begin{array}{c}-2.204 * * * * \\
(0.396)\end{array}$ & $\begin{array}{c}-2.152^{* * *} * \\
(0.498)\end{array}$ & $\begin{array}{c}-1.244^{*} \\
(0.649)\end{array}$ \\
\hline ATE-AIPW Low & $\begin{array}{c}-0.713 * * * * \\
(0.135)\end{array}$ & $\begin{array}{c}-1.498 * * * * \\
(0.235)\end{array}$ & $\begin{array}{c}-2.212 * * * \\
(0.308)\end{array}$ & $\begin{array}{c}-2.729^{* * * *} \\
(0.399)\end{array}$ & $\begin{array}{c}-3.262 * * * \\
(0.483)\end{array}$ & $\begin{array}{c}-3.808 * * * \\
(0.579)\end{array}$ \\
\hline P-value High=Low & 0.001 & 0.000 & 0.241 & 0.013 & 0.000 & 0.000 \\
\hline Avg.(trade) in countries above cutoff & 1.510 & 3.092 & 4.702 & 6.371 & 7.869 & 9.484 \\
\hline Avg.(trade) in countries below cutoff & 0.991 & 2.024 & 3.224 & 4.549 & 5.844 & 7.387 \\
\hline \multicolumn{7}{|l|}{ Panel e: Services } \\
\hline ATE-AIPW High & $\begin{array}{c}-0.692^{* * * *} \\
(0.081)\end{array}$ & $\begin{array}{c}-0.643 * * * * \\
(0.143)\end{array}$ & $\begin{array}{c}-1.296^{* * *} \\
(0.187)\end{array}$ & $\begin{array}{c}-1.247^{* * * *} \\
(0.252)\end{array}$ & $\begin{array}{c}-1.034 * * * \\
(0.304)\end{array}$ & $\begin{array}{c}-1.134^{* * *} \\
(0.392)\end{array}$ \\
\hline ATE-AIPW Low & $\begin{array}{c}-0.840 * * * \\
(0.075)\end{array}$ & $-0.811^{* * *}$ & $-0.657 * *$ & $-0.687 * * *$ & $-1.288 * * *$ & $-1.850^{* * *}$ \\
\hline P-value High=Low & $\frac{(0.075)}{0.005}$ & $(0.122)$ & $(0.183)$ & $(0.266)$ & $(0.307)$ & $\frac{(0.353)}{0.018}$ \\
\hline Avg.(trade) in countri & 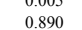 & 1.798 & $\begin{array}{l}0.000 \\
2.785\end{array}$ & $\begin{array}{l}0.003 \\
3.841\end{array}$ & $\begin{array}{l}0.291 \\
4.827\end{array}$ & $\begin{array}{l}0.018 \\
5.881\end{array}$ \\
\hline Avg.(trade) in countries below cutoff & 0.728 & 1.445 & 2.274 & 3.141 & 4.003 & 4.986 \\
\hline Observations & 710 & 710 & 710 & 710 & 710 & 710 \\
\hline \# of Crises & 19 & 19 & 19 & 19 & 19 & 19 \\
\hline Cutoff of channel variable, median & -2.659 & -2.659 & -2.659 & -2.659 & -2.659 & -2.659 \\
\hline
\end{tabular}

\begin{tabular}{|c|c|c|c|c|c|c|}
\hline \multicolumn{7}{|c|}{ Panel II: Imports (\% of pre-crisis GDP) } \\
\hline & (1) & (2) & (3) & (4) & (5) & (6) \\
\hline & $\mathrm{h}=\mathbf{0}$ & $\mathrm{h}=\mathbf{1}$ & $\mathrm{h}=\mathbf{2}$ & $\mathrm{h}=\mathbf{3}$ & $h=4$ & $\mathrm{~h}=5$ \\
\hline \multirow{2}{*}{\multicolumn{7}{|c|}{ Panel C: Currency crises }} \\
\hline \multicolumn{5}{|l|}{ Panel a: Total } & & \\
\hline ATE-AIPW High & $\begin{array}{c}-4.646 * * * \\
(0.415)\end{array}$ & $\begin{array}{c}-5.541^{* * *} * \\
(0.556)\end{array}$ & $\begin{array}{c}-6.528^{* * *} \\
(0.784)\end{array}$ & $\begin{array}{c}-7.934 * * * \\
(1.023)\end{array}$ & $\begin{array}{c}-7.824 * * * \\
(1.248)\end{array}$ & $\begin{array}{c}-5.638^{* * * *} \\
(1.638)\end{array}$ \\
\hline ATE-AIPW Low & $-6.056^{* * *}$ & $-8.521 * * *$ & $-10.785^{* * *}$ & $-11.023 * * *$ & $-11.202^{* * *}$ & $-11.450^{* * *}$ \\
\hline & $(0.419)$ & $(0.590)$ & $(0.805)$ & $(1.012)$ & $(1.214)$ & $(1.389)$ \\
\hline value High=Low & 0.000 & 0.000 & 0.000 & 0.000 & 0.000 & 0.000 \\
\hline & 3.961 & 7.986 & 12.116 & 16.485 & 20.600 & 24.793 \\
\hline Avg.(trade) in countries belov & 3.144 & 6.446 & 10.070 & 14.116 & 18.242 & 22.809 \\
\hline
\end{tabular}

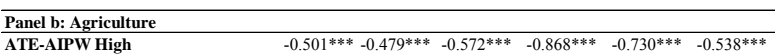

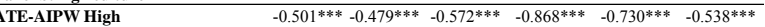
$\begin{array}{lcccccc} & (0.083) & (0.070) & (0.094) & (0.110) & (0.139) & (0.173) \\ \text { ATE-AIPW Low } & -0.580^{* * *} & -0.680^{* * *} & -0.996 * * * & -1.050^{* * *} & -0.927 * * * & -0.921^{* * *}\end{array}$

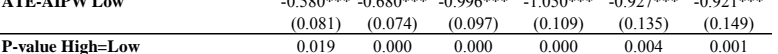
$\begin{array}{lllllll}\text { P-value High=Low } & 0.019 & 0.000 & 0.000 & 0.000 & 0.004 & 0.001 \\ \text { Avg.(trade) in countries above cutoff } & 0.328 & 0.701 & 1.083 & 1.486 & 1.896 & 2.311\end{array}$ \begin{tabular}{lllllll} 
Avg.(trade) in countries below cutoff & 0.337 & 0.651 & 0.994 & 1.412 & 1.807 & 2.259 \\
\hline
\end{tabular}

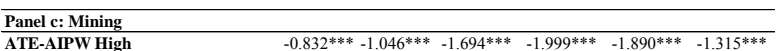
\begin{tabular}{lllllll}
\hline ATE-AIPW High & $-0.832^{* * *}$ & $-1.046^{* * *}$ & $-1.694^{* *}$ & $-1.999^{* * * *}$ & $-1.890^{* *}$ & $-1.315^{* * *}$ \\
& $(0.079)$ & $(0.134)$ & $(0.173)$ & $(0.234)$ & $(0.270)$ & $(0.389)$
\end{tabular}

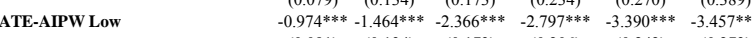
\begin{tabular}{lcccccc} 
& $(0.091)$ & $(0.134)$ & $(0.173)$ & $(0.206)$ & $(0.242)$ & $(0.273)$ \\
\hline P-value High=Low & 0.033 & 0.000 & 0.000 & 0.000 & 0.000 & 0.000
\end{tabular} \begin{tabular}{lllllll} 
Avg.(trade) in countries above cutoff & 0.696 & 1.427 & 2.180 & 2.959 & 3.586 & 4.166 \\
\hline
\end{tabular} \begin{tabular}{lllllll} 
Avg.(trade) in countries below cutoff & 0.464 & 0.988 & 1.606 & 2.294 & 2.958 & 3.687 \\
\hline
\end{tabular}

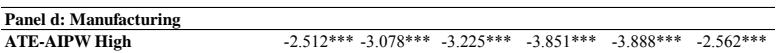

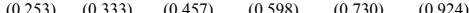

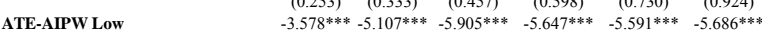
\begin{tabular}{lcccccc} 
& $(0.261)$ & $(0.370)$ & $(0.482)$ & $(0.605)$ & $(0.727)$ & $(0.843)$ \\
\hline P-value High=Low & 0.000 & 0.000 & 0.000 & 0.000 & 0.000 & 0.000
\end{tabular} \begin{tabular}{lllllll} 
Avg.(trade) in countries above cutoff & 2.290 & 4.569 & 6.844 & 9.240 & 11.616 & 14.045 \\
\hline
\end{tabular} \begin{tabular}{lllllll} 
Avg.(trade) in countries below cutoff & 1.782 & 3.606 & 5.644 & 7.842 & 10.158 & 12.786 \\
\hline
\end{tabular}

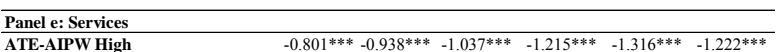

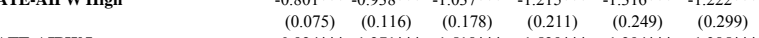
$\begin{array}{llllll}\text { ATE-AIPW Low } \quad-0.924^{* * *} & -1.271^{* * *} & -1.518^{* * *} & -1.529 * * * & -1.294^{* * *} & -1.385^{* * *}\end{array}$ \begin{tabular}{lcccccc} 
& $(0.076)$ & $(0.123)$ & $(0.176)$ & $(0.217)$ & $(0.248)$ & $(0.274)$ \\
\hline P-value High=Low & 0.021 & 0.000 & 0.000 & 0.016 & 0.898 & 0.469
\end{tabular} $\begin{array}{lllllll}\text { Avg.(trade) in countries above cutoff } & 0.647 & 1.288 & 2.008 & 2.801 & 3.502 & 4.272\end{array}$

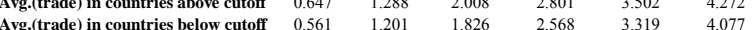
\begin{tabular}{lcccccc} 
Avg.(trade) in countries below cutoff & 0.561 & 1.201 & 1.826 & 2.568 & 3.319 & 4.077 \\
\hline Observations & 710 & 710 & 710 & 710 & 710 & 710
\end{tabular}

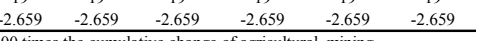

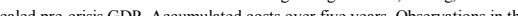

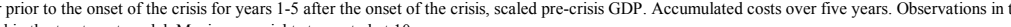
treated and control groups are weighted by the propensity scores predicted in the treatment model. Maximum weights truncated at 10. 
Table A.18a: Channels, Cumulative trade losses over five years after debt crises with higher and lower trading partners' growth

\begin{tabular}{|c|c|c|c|c|c|c|c|c|c|c|c|c|c|}
\hline \multicolumn{7}{|c|}{ Panel I: Exports (\% of pre-crisis GDP) } & \multicolumn{7}{|c|}{ Panel II: Imports (\% of pre-crisis GDP) } \\
\hline & (1) & (2) & (3) & (4) & (5) & (6) & & (1) & (2) & (3) & (4) & (5) & (6) \\
\hline & $\mathrm{h}=\mathbf{0}$ & $\mathrm{h}=1$ & $\mathrm{~h}=\mathbf{2}$ & $h=3$ & $h=4$ & $h=5$ & & $\mathbf{h}=\mathbf{0}$ & $\mathrm{h}=\mathbf{1}$ & $\mathrm{h}=\mathbf{2}$ & $h=3$ & $h=4$ & $h=5$ \\
\hline \multicolumn{7}{|c|}{ Panel A: Debt crises } & \multicolumn{7}{|c|}{ Panel A: Debt crises } \\
\hline Panel a: Total & & & & & & & Panel a: Total & & & & & & \\
\hline ATE-AIPW High & $\begin{array}{l}-0.172 \\
(0.309)\end{array}$ & $\begin{array}{c}-1.326 * * * \\
(0.466)\end{array}$ & $\begin{array}{c}-2.185 * * * \\
(0.606)\end{array}$ & $\begin{array}{c}*-4.365 * * * \\
(0.810)\end{array}$ & $\begin{array}{c}-2.954 * * * \\
(1.048)\end{array}$ & $\begin{array}{c}0.138 \\
(1.376)\end{array}$ & ATE-AIPW High & $\begin{array}{c}-1.994 * * * \\
(0.414)\end{array}$ & $\begin{array}{c}-2.942 * * * \\
(0.620)\end{array}$ & $\begin{array}{c}-2.033^{* *} \\
(0.950)\end{array}$ & $\begin{array}{l}-2.356^{*} \\
(1.273)\end{array}$ & $\begin{array}{c}-3.811^{* *} \\
(1.758)\end{array}$ & $\begin{array}{c}-0.008 \\
(2.514)\end{array}$ \\
\hline \multirow[t]{2}{*}{ ATE-AIPW Low } & $-2.507^{* * * *}$ & $*-4.443 * * *$ & $-5.493 * * *$ & $*-8.602 * * *$ & $-11.205 * * *$ & $-13.270^{* * *}$ & ATE-AIPW Low & $-5.291 * * *$ & $-8.481 * * *$ & $*-11.274 * *$ & $*-13.819^{* * *}$ & $*-15.840^{* * *}$ & $-19.211^{* * *}$ \\
\hline & $(0.265)$ & $(0.397)$ & $(0.572)$ & $(0.798)$ & $(0.963)$ & $(1.170)$ & & $(0.410)$ & $(0.624)$ & $(0.926)$ & $(1.209)$ & $(1.668)$ & $(2.232)$ \\
\hline P-value High=Low & 0.000 & 0.000 & 0.000 & 0.000 & 0.000 & 0.000 & P-value High=Low & 0.000 & 0.000 & 0.000 & 0.000 & 0.000 & 0.000 \\
\hline Avg.(trade) in countries above cutoff & 3.398 & 7.038 & 10.886 & 14.885 & 18.763 & 22.794 & Avg.(trade) in countries above cutoff & 4.046 & 8.612 & 13.261 & 18.035 & 22.883 & 27.790 \\
\hline Avg.(trade) in countries below cutoff & 1.239 & 1.969 & 3.337 & 5.137 & 6.293 & 7.925 & Avg.(trade) in countries below cutoff & 1.536 & 1.762 & 2.502 & 4.440 & 5.702 & 7.410 \\
\hline \multicolumn{7}{|l|}{ Panel b: Agriculture } & \multicolumn{7}{|l|}{ Panel b: Agriculture } \\
\hline ATE-AIPW High & $\begin{array}{c}0.502^{* * *} \\
(0.084)\end{array}$ & $\begin{array}{c}0.609^{* * *} \\
(0.131)\end{array}$ & $\begin{array}{c}0.562^{* * *} \\
(0.168)\end{array}$ & $\begin{array}{c}0.753^{* * *} \\
(0.214)\end{array}$ & $\begin{array}{c}1.796^{* * *} \\
(0.352)\end{array}$ & $\begin{array}{c}4.327^{* * *} \\
(0.624)\end{array}$ & ATE-AIPW High & $\begin{array}{l}-0.095 \\
(0.064)\end{array}$ & $\begin{array}{c}-0.220^{* * *} \\
(0.078)\end{array}$ & $\begin{array}{c}-0.285^{* *} \\
(0.135)\end{array}$ & $\begin{array}{c}-0.599^{* * *} \\
(0.164)\end{array}$ & $\begin{array}{c}-0.932 * * * \\
(0.219)\end{array}$ & $\begin{array}{c}-0.541^{*} \\
(0.300)\end{array}$ \\
\hline ATE-AIPW Low & $\begin{array}{c}-0.973 * * * \\
(0.100)\end{array}$ & $\begin{array}{c}*-0.594 * * * \\
(0.092)\end{array}$ & $\begin{array}{l}-0.020 \\
(0.153)\end{array}$ & $\begin{array}{c}0.096 \\
(0.251)\end{array}$ & $\begin{array}{c}-0.696^{* * * *} \\
(0.258)\end{array}$ & $\begin{array}{c}-0.980^{* * * *} \\
(0.227)\end{array}$ & ATE-AIPW Low & $\begin{array}{c}-0.363 * * * \\
(0.066)\end{array}$ & $\begin{array}{c}-0.903 * * * \\
(0.075)\end{array}$ & $\begin{array}{c}{ }^{*}-0.973^{* * * *} \\
(0.132)\end{array}$ & $\begin{array}{c}-1.290^{* * *} \\
(0.160)\end{array}$ & $\begin{array}{c}-1.640^{* * *} * \\
(0.215)\end{array}$ & $\begin{array}{c}-1.735^{* * *} \\
(0.291)\end{array}$ \\
\hline $\begin{array}{l}\text { P-value High=Low } \\
\end{array}$ & 0.000 & 0.000 & 0.000 & 0.013 & 0.000 & 0.000 & P-value High=Low & 0.000 & 0.000 & 0.000 & 0.000 & 0.000 & 0.000 \\
\hline Avg.(trade) in countries above cutoff & 0.438 & 0.907 & 1.389 & 1.897 & 2.403 & 2.981 & Avg.(trade) in countries above cutoff & 0.354 & 0.774 & 1.188 & 1.632 & 2.098 & 2.580 \\
\hline Avg.(trade) in countries below cutoff & 0.131 & 0.218 & 0.525 & 0.791 & 0.900 & 1.191 & Avg.(trade) in countries below cutoff & 0.219 & 0.273 & 0.424 & 0.690 & 0.832 & 1.064 \\
\hline \multicolumn{7}{|l|}{ Panel c: Mining } & \multicolumn{7}{|l|}{ Panel c: Mining } \\
\hline ATE-AIPW High & $\begin{array}{c}0.488^{* *} \\
(0.205)\end{array}$ & $\begin{array}{c}0.478 * * \\
(0.237)\end{array}$ & $\begin{array}{l}0.524^{* * *} \\
(0.257)\end{array}$ & $\begin{array}{c}0.106 \\
(0.324)\end{array}$ & $\begin{array}{c}1.599^{* * * *} \\
(0.398)\end{array}$ & $\begin{array}{c}3.184^{* * *} \\
(0.535)\end{array}$ & \multirow{2}{*}{ ATE-AIPW Low } & $\begin{array}{c}-0.244^{* * * *} \\
(0.085)\end{array}$ & $\begin{array}{c}0.005 \\
(0.169)\end{array}$ & $\begin{array}{c}0.077 \\
(0.211)\end{array}$ & $\begin{array}{l}-0.083 \\
(0.287)\end{array}$ & $\begin{array}{c}0.045 \\
(0.374)\end{array}$ & $\begin{array}{l}0.957^{*} \\
(0.535)\end{array}$ \\
\hline ATE-AIPW Low & $\begin{array}{c}-0.112 \\
(0.117)\end{array}$ & $\begin{array}{c}-0.621 * * * \\
(0.163)\end{array}$ & $\begin{array}{c}-1.420^{* * * *} \\
(0.225)\end{array}$ & $\begin{array}{c}{ }^{*}-3.027 * * * \\
(0.319)\end{array}$ & $\begin{array}{c}-3.506 * * * \\
(0.373)\end{array}$ & $\begin{array}{c}-4.160^{* * * *} \\
(0.442)\end{array}$ & & $\begin{array}{c}-0.599 * * * \\
(0.081)\end{array}$ & $\begin{array}{c}-1.073^{* * *} \\
(0.136)\end{array}$ & $\begin{array}{c}-1.682 * * * \\
(0.183)\end{array}$ & $\begin{array}{c}-2.655^{* * *} \\
(0.253)\end{array}$ & $\begin{array}{c}-3.361 * * * \\
(0.357)\end{array}$ & $\begin{array}{c}-4.206^{* * *} \\
(0.462)\end{array}$ \\
\hline P-value High=Low & 0.001 & 0.000 & 0.000 & 0.000 & 0.000 & 0.000 & P-value High=Low & 0.000 & 0.000 & 0.000 & 0.000 & 0.000 & 0.000 \\
\hline Avg.(trade) in countries above cutoff & 0.674 & 1.385 & 2.089 & 2.910 & 3.670 & 4.399 & Avg.(trade) in countries above cutoff & 0.691 & 1.508 & 2.345 & 3.203 & 3.988 & 4.785 \\
\hline Avg.(trade) in countries below cutoff & -0.098 & -0.249 & -0.043 & -0.086 & -0.287 & -0.413 & Avg.(trade) in countries below cutoff & 0.154 & 0.062 & 0.115 & 0.316 & 0.384 & 0.336 \\
\hline \multicolumn{7}{|l|}{ Panel d: Manufacturing } & \multicolumn{7}{|l|}{ Panel d: Manufacturing } \\
\hline ATE-AIPW High & $\begin{array}{c}-0.684 * * * \\
(0.139)\end{array}$ & $\begin{array}{c}* 1.246 * * * \\
(0.260)\end{array}$ & $\begin{array}{c}-2.044 * * * \\
(0.326)\end{array}$ & $\begin{array}{c}-3.457 * * * \\
(0.409)\end{array}$ & $\begin{array}{c}-4.317 * * * \\
(0.515)\end{array}$ & $\begin{array}{c}-4.737 * * * \\
(0.629)\end{array}$ & ATE-AIPW High & $\begin{array}{c}-1.124 * * * \\
(0.271)\end{array}$ & $\begin{array}{c}-1.749 * * * \\
(0.379)\end{array}$ & $\begin{array}{l}-0.641 \\
(0.582)\end{array}$ & $\begin{array}{l}-0.423 \\
(0.779)\end{array}$ & $\begin{array}{l}-1.560 \\
(1.073)\end{array}$ & $\begin{array}{c}0.609 \\
(1.535)\end{array}$ \\
\hline \multirow[t]{2}{*}{ ATE-AIPW Low } & $-0.944 * * *$ & $*-1.876 * * *$ & $-2.578^{* * *}$ & $*-3.785 * * *$ & $-4.767 * * *$ & $-5.246^{* * * *}$ & \multirow[t]{2}{*}{ ATE-AIPW Low } & $-3.070^{* * *}$ & $-4.905^{* * *}$ & ${ }^{*}-6.402 * * *$ & $-7.558^{* * *}$ & $-8.197^{* * *}$ & $-10.014^{* * *}$ \\
\hline & $(0.135)$ & $(0.227)$ & $(0.318)$ & $(0.403)$ & $(0.503)$ & $(0.613)$ & & $(0.265)$ & $(0.396)$ & $(0.560)$ & $(0.689)$ & $(0.933)$ & $(1.249)$ \\
\hline P-value High=Low & 0.000 & 0.000 & 0.000 & 0.003 & 0.003 & 0.010 & P-value High=Low & 0.000 & 0.000 & 0.000 & 0.000 & 0.000 & 0.000 \\
\hline Avg.(trade) in countries above cutoff & 1.405 & 2.936 & 4.546 & 6.147 & 7.723 & 9.355 & Avg.(trade) in countries above cutoff & 2.328 & 4.894 & 7.475 & 10.074 & 12.796 & 15.565 \\
\hline Avg.(trade) in countries below cutoff & 0.704 & 1.146 & 1.655 & 2.702 & 3.438 & 4.293 & Avg.(trade) in countries below cutoff & 0.859 & 0.994 & 1.461 & 2.604 & 3.514 & 4.724 \\
\hline \multicolumn{7}{|l|}{ Panel e: Services } & Panel e: Services & & & & & & \\
\hline ATE-AIPW High & $\begin{array}{c}-0.478^{* * * *} \\
(0.086)\end{array}$ & $\begin{array}{c}* 1.167^{* * * *} \\
(0.136)\end{array}$ & $\begin{array}{c}-1.227 * * * \\
(0.199)\end{array}$ & $\begin{array}{c}-1.767 * * * \\
(0.257)\end{array}$ & $\begin{array}{c}-2.032 * * * \\
(0.328)\end{array}$ & $\begin{array}{c}-2.635 * * * \\
(0.427)\end{array}$ & ATE-AIPW High & $\begin{array}{c}-0.530^{* * * *} \\
(0.090)\end{array}$ & $\begin{array}{c}-0.977^{* * *} \\
(0.137)\end{array}$ & $\begin{array}{c}-1.184^{* * * *} \\
(0.189)\end{array}$ & $\begin{array}{c}-1.250^{* * * *} \\
(0.227)\end{array}$ & $\begin{array}{c}-1.364 * * * \\
(0.282)\end{array}$ & $\begin{array}{c}-1.032^{* * * *} \\
(0.351)\end{array}$ \\
\hline ATE-AIPW Low & $-0.478^{* * *}$ & $*-1.352 * * *$ & $-1.476 * * *$ & $-1.886^{* * *}$ & $-2.236^{* * *}$ & $-2.883^{* * *}$ & ATE-AIPW Low & $-1.259^{* * *}$ & $-1.599 * * *$ & ${ }^{*}-2.218^{* * *}$ & $-2.315^{* * *}$ & $-2.642 * * *$ & $-3.256 * * *$ \\
\hline & $(0.084)$ & $(0.136)$ & $(0.192)$ & $(0.264)$ & $(0.329)$ & $(0.424)$ & & $(0.103)$ & $(0.139)$ & $(0.183)$ & $(0.229)$ & $(0.294)$ & $(0.357)$ \\
\hline P-value High=Low & 0.994 & 0.001 & 0.013 & 0.342 & 0.124 & 0.126 & P-value High=Low & 0.000 & 0.000 & 0.000 & 0.000 & 0.000 & 0.000 \\
\hline Avg.(trade) in countries above cutoff & 0.881 & 1.810 & 2.863 & 3.931 & 4.967 & 6.059 & Avg.(trade) in countries above cutoff & 0.672 & 1.436 & 2.253 & 3.125 & 4.001 & 4.861 \\
\hline Avg.(trade) in countries below cutoff & 0.501 & 0.854 & 1.201 & 1.730 & 2.242 & 2.854 & Avg.(trade) in countries below cutoff & 0.305 & 0.434 & 0.501 & 0.829 & 0.971 & 1.287 \\
\hline Observations & 698 & 698 & 698 & 698 & 698 & 698 & Observations & 698 & 698 & 698 & 698 & 698 & 698 \\
\hline \# of Crises & 19 & 19 & 19 & 19 & 19 & 19 & \# of Crises & 19 & 19 & 19 & 19 & 19 & 19 \\
\hline Cutoff of channel variable, median & 7.041 & 7.041 & 7.041 & 7.041 & 7.041 & 7.041 & Cutoff of channel variable, median & 7.041 & 7.041 & 7.041 & 7.041 & 7.041 & 7.041 \\
\hline
\end{tabular}

CInternational Monetary Fund. Not for Redistribution 
Table A.18b: Channels, Cumulative trade losses over five years after banking crises with higher and lower trading partners' growth

\begin{tabular}{|c|c|c|c|c|c|c|}
\hline \multicolumn{7}{|c|}{ Panel I: Exports (\% of pre-crisis GDP) } \\
\hline & (1) & (2) & (3) & (4) & (5) & (6) \\
\hline & $\mathbf{h}=\mathbf{0}$ & $\mathrm{h}=1$ & $\mathrm{~h}=\mathbf{2}$ & $h=3$ & $h=4$ & $h=5$ \\
\hline \multicolumn{7}{|c|}{ Panel B: Banking crises } \\
\hline \multicolumn{7}{|l|}{ Panel a: Total } \\
\hline ATE-AIPW High & $\begin{array}{c}-1.192 * * * \\
(0.317)\end{array}$ & $\begin{array}{c}-4.281 * * * \\
(0.516)\end{array}$ & $\begin{array}{c}-4.924 * * * \\
(0.575)\end{array}$ & $\begin{array}{c}-5.350^{* * *} \\
(0.697)\end{array}$ & $\begin{array}{c}-8.152^{* * *} \\
(0.916)\end{array}$ & $\begin{array}{c}-8.547^{* * *} \\
(1.126)\end{array}$ \\
\hline ATE-AIPW Low & $\begin{array}{c}-1.372 * * * \\
(0.304)\end{array}$ & $\begin{array}{c}-4.084 * * * \\
(0.515)\end{array}$ & $\begin{array}{c}-5.190^{* * * *} \\
(0.573)\end{array}$ & $\begin{array}{c}-5.163 * * * \\
(0.740)\end{array}$ & $\begin{array}{c}-6.886^{* * * *} \\
(0.974)\end{array}$ & $\begin{array}{c}-7.061 * * * \\
(1.135)\end{array}$ \\
\hline P-value High=Low & 0.387 & 0.382 & 0.294 & 0.600 & 0.007 & 0.010 \\
\hline Avg.(trade) in countries above cutoff & 3.566 & 7.497 & 11.648 & 15.781 & 19.801 & 23.915 \\
\hline Avg.(trade) in countries below cutoff & 1.547 & 2.546 & 4.018 & 6.215 & 7.919 & 10.127 \\
\hline \multicolumn{7}{|l|}{ Panel b: Agriculture } \\
\hline ATE-AIPW High & $\begin{array}{c}-0.200^{* * * *} \\
(0.062)\end{array}$ & $\begin{array}{c}-0.509 * * * \\
(0.092)\end{array}$ & $\begin{array}{c}-0.635^{* * *} \\
(0.119)\end{array}$ & $\begin{array}{c}-0.773^{* * *} \\
(0.148)\end{array}$ & $\begin{array}{c}-1.037^{* * *} \\
(0.176)\end{array}$ & $\begin{array}{c}-1.352^{* * *} \\
(0.211)\end{array}$ \\
\hline ATE-AIPW Low & $\begin{array}{l}-0.050 \\
(0.063)\end{array}$ & $\begin{array}{c}-0.413^{* * * *} \\
(0.093)\end{array}$ & $\begin{array}{c}-0.648 * * * \\
(0.113)\end{array}$ & $\begin{array}{c}-0.860^{* * *} \\
(0.130)\end{array}$ & $\begin{array}{c}-1.135 * * * \\
(0.152)\end{array}$ & $\begin{array}{c}-1.660^{* * * *} \\
(0.182)\end{array}$ \\
\hline P-value High=Low & 0.000 & 0.108 & 0.884 & 0.366 & 0.384 & 0.009 \\
\hline Avg.(trade) in countries above cutoff & 0.469 & 0.975 & 1.506 & 2.034 & 2.537 & 3.151 \\
\hline Avg.(trade) in countries below cutoff & 0.159 & 0.283 & 0.534 & 0.832 & 1.075 & 1.376 \\
\hline \multicolumn{7}{|l|}{ Panel c: Mining } \\
\hline ATE-AIPW High & $\begin{array}{c}0.009 \\
(0.171)\end{array}$ & $\begin{array}{c}-0.679 * * * \\
(0.226)\end{array}$ & $\begin{array}{l}-0.428^{*} \\
(0.245)\end{array}$ & $\begin{array}{l}-0.577^{*} \\
(0.311)\end{array}$ & $\begin{array}{c}-1.508^{* * *} \\
(0.406)\end{array}$ & $\begin{array}{c}-1.441^{* * *} \\
(0.463)\end{array}$ \\
\hline ATE-AIPW Low & $\begin{array}{l}-0.090 \\
(0.153)\end{array}$ & $\begin{array}{c}-0.518^{* *} \\
(0.220)\end{array}$ & $\begin{array}{c}-1.177^{* * *} \\
(0.223)\end{array}$ & $\begin{array}{c}-1.831 * * * \\
(0.278)\end{array}$ & $\begin{array}{c}-2.266 * * * \\
(0.383)\end{array}$ & $\begin{array}{c}-1.374 * * * \\
(0.494)\end{array}$ \\
\hline$\overline{P \text {-value High=Low }}$ & 0.309 & 0.050 & 0.000 & 0.000 & 0.000 & 0.812 \\
\hline Avg.(trade) in countries above cutoff & 0.739 & 1.537 & 2.358 & 3.221 & 4.035 & 4.789 \\
\hline Avg.(trade) in countries below cutoff & 0.002 & -0.071 & 0.025 & 0.164 & 0.148 & 0.239 \\
\hline \multicolumn{7}{|l|}{ Panel d: Manufacturing } \\
\hline ATE-AIPW High & $\begin{array}{c}-0.429 * * * \\
(0.159)\end{array}$ & $\begin{array}{c}-0.993 * * * \\
(0.288)\end{array}$ & $\begin{array}{c}-1.162^{* * * *} \\
(0.380)\end{array}$ & $\begin{array}{c}-1.199 * * \\
(0.465)\end{array}$ & $\begin{array}{c}-2.120^{* * *} \\
(0.532)\end{array}$ & $\begin{array}{c}-2.465 * * * \\
(0.647)\end{array}$ \\
\hline ATE-AIPW Low & $\begin{array}{c}-0.448^{* * *} \\
(0.151)\end{array}$ & $\begin{array}{c}-1.742 * * * \\
(0.263)\end{array}$ & $\begin{array}{c}-1.791 * * * \\
(0.323)\end{array}$ & $\begin{array}{c}-1.070^{* *} \\
(0.429)\end{array}$ & $\begin{array}{c}-1.254^{* *} \\
(0.557)\end{array}$ & $\begin{array}{l}-0.938 \\
(0.690)\end{array}$ \\
\hline$\overline{\text { P-value High=Low }}$ & 0.846 & 0.000 & 0.015 & 0.704 & 0.018 & 0.002 \\
\hline Avg.(trade) in countries above cutoff & 1.442 & 3.063 & 4.762 & 6.430 & 8.053 & 9.666 \\
\hline Avg.(trade) in countries below cutoff & 0.845 & 1.429 & 2.087 & 3.160 & 4.057 & 5.205 \\
\hline \multicolumn{7}{|l|}{ Panel e: Services } \\
\hline ATE-AIPW High & $\begin{array}{c}-0.572^{* * * *} \\
(0.091)\end{array}$ & $\begin{array}{c}-2.101 * * * \\
(0.157)\end{array}$ & $\begin{array}{c}-2.699 * * * \\
(0.224)\end{array}$ & $\begin{array}{c}-2.802^{* * *} \\
(0.297)\end{array}$ & $\begin{array}{c}-3.488^{* * *} \\
(0.380)\end{array}$ & $\begin{array}{c}-3.290^{* * * *} \\
(0.500)\end{array}$ \\
\hline \multirow[t]{2}{*}{ ATE-AIPW Low } & $-0.784 * * *$ & $-1.412^{* * * *}$ & $-1.575 * *$ & $-1.402 * * *$ & $-2.231 * * *$ & $-3.089 * * *$ \\
\hline & $(0.096)$ & $(0.144)$ & $(0.197)$ & $(0.274)$ & $(0.350)$ & $(0.415)$ \\
\hline P-value High=Low & 0.005 & 0.000 & 0.000 & 0.000 & 0.000 & 0.545 \\
\hline Avg.(trade) in countries above cutoff & 0.916 & 1.922 & 3.021 & 4.096 & 5.175 & 6.310 \\
\hline Avg.(trade) in countries below cutoff & 0.541 & 0.905 & 1.373 & 2.059 & 2.639 & 3.308 \\
\hline Observations & 700 & 700 & 700 & 700 & 700 & 700 \\
\hline$\#$ of Crises & 18 & 18 & 18 & 18 & 18 & 18 \\
\hline Cutoff of channel variable, median & 7.984 & 7.984 & 7.984 & 7.984 & 7.984 & 7.984 \\
\hline
\end{tabular}

\begin{tabular}{|c|c|c|c|c|c|c|}
\hline \multicolumn{7}{|c|}{ Panel II: Imports (\% of pre-crisis GDP) } \\
\hline & (1) & (2) & (3) & (4) & (5) & (6) \\
\hline & $\mathbf{h}=\mathbf{0}$ & $\mathrm{h}=1$ & $\mathrm{~h}=2$ & $\mathrm{~h}=\mathbf{3}$ & $h=4$ & $h=5$ \\
\hline \multicolumn{7}{|c|}{ Panel B: Banking crises } \\
\hline \multicolumn{7}{|l|}{ Panel a: Total } \\
\hline ATE-AIPW High & $\begin{array}{c}-3.316 * * * \\
(0.455)\end{array}$ & $\begin{array}{c}-8.238 * * * \\
(0.745)\end{array}$ & $\begin{array}{c}-10.201 * * * \\
(0.812)\end{array}$ & $\begin{array}{c}-10.742^{* * * *} \\
(0.956)\end{array}$ & $\begin{array}{c}-11.746^{* * * *} \\
(1.226)\end{array}$ & $\begin{array}{c}-12.816 * * * \\
(1.428)\end{array}$ \\
\hline ATE-AIPW Low & $\begin{array}{c}-2.543 * * * \\
(0.479)\end{array}$ & $\begin{array}{c}-3.910^{* * * *} \\
(0.736)\end{array}$ & $\begin{array}{c}-5.419^{* * *} \\
(0.816)\end{array}$ & $\begin{array}{c}-6.725 * * * \\
(0.993)\end{array}$ & $\begin{array}{c}-8.888 * * * \\
(1.281)\end{array}$ & $\begin{array}{c}-11.218^{* * *} \\
(1.485)\end{array}$ \\
\hline ligh=Low & 0.024 & 0.000 & 0.000 & 0.000 & 0.000 & 0.046 \\
\hline i: & 4.403 & 9.231 & 14.243 & 19.193 & 24.208 & 29.261 \\
\hline Avg.(trade) in countries below cutoff & 1.528 & 2.544 & 3.707 & 6.150 & 8.179 & 10.579 \\
\hline
\end{tabular}

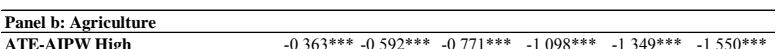

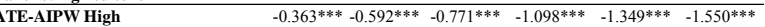
\begin{tabular}{lcccccc} 
& $(0.053)$ & $(0.093)$ & $(0.098)$ & $(0.110)$ & $(0.140)$ & $(0.157)$ \\
ATE-AIPW Low & -0.087 & $0.622 * * *$ & $0.276 * *$ & -0.035 & -0.244 & $-1.051 * * *$ \\
\hline
\end{tabular} \begin{tabular}{lrrrrrr} 
& -0.087 & $0.622^{* * *}$ & $0.276^{* *}$ & -0.035 & -0.244 & $-1.051^{* *}$ \\
& $(0.073)$ & $(0.107)$ & $(0.111)$ & $(0.122)$ & $(0.157)$ & $(0.169)$ \\
\hline P-value High=Low & 0.000 & 0.000 & 0.000 & 0.000 & 0.000 & 0.000
\end{tabular} \begin{tabular}{lllllll}
\hline P-value High=Low & 0.000 & 0.000 & 0.000 & 0.000 & 0.000 & 0.000
\end{tabular}

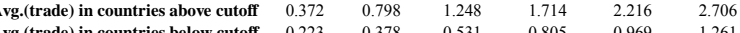
\begin{tabular}{lllllll} 
Avg.(trade) in countries below cutoff & 0.223 & 0.378 & 0.531 & 0.805 & 0.969 & 1.261 \\
\hline
\end{tabular}

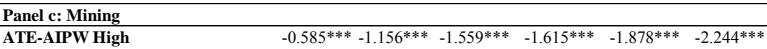

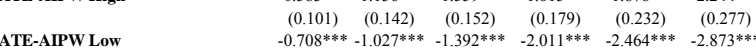
\begin{tabular}{lcccccc} 
& $(0.098)$ & $(0.145)$ & $(0.154)$ & $(0.184)$ & $(0.228)$ & $(0.270)$ \\
\hline P-value High=Low & 0.001 & 0.033 & 0.009 & 0.000 & 0.000 & 0.000
\end{tabular} \begin{tabular}{lllllll} 
Avg.(trade) in countries above cutoff & 0.778 & 1.661 & 2.609 & 3.521 & 4.370 & 5.213 \\
\hline
\end{tabular} \begin{tabular}{lllllll} 
Avg.(trade) in countries below cutoff & 0.129 & 0.176 & 0.229 & 0.517 & 0.666 & 0.784 \\
\hline
\end{tabular}

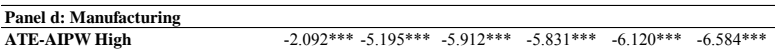
$\begin{array}{lllllll} & (0.271) & (0.448) & (0.494) & (0.583) & (0.742) & (0.861) \\ & -1.324 * & -2.89 * * & -3.24 * * 2 & -3.35 * & -4.327 * * & -5.187^{* *}\end{array}$

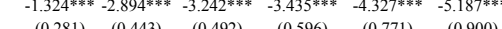
\begin{tabular}{lcccccc}
\hline P-value High=Low & 0.000 & 0.000 & 0.000 & 0.000 & 0.000 & 0.013 \\
\hline
\end{tabular} \begin{tabular}{lllllll} 
Avg.(trade) in countries abe cutoff & 0.899 & 1.477 & 2.964 & 10.650 & 13.449 & 16.297 \\
\hline
\end{tabular} \begin{tabular}{llllll}
\hline Panel e: Services & & \\
\hline ATE
\end{tabular}

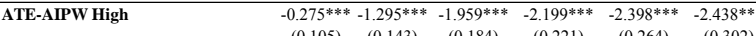
\begin{tabular}{llllll} 
ATE-AIPW Low $\quad-0.424^{* * * *}$ & $-0.612^{* * *}$ & $-1.062^{* * *}$ & $-1.244^{* * *}$ & $-1.853^{* * *}$ & $-2.107^{* * *}$ \\
\hline
\end{tabular} \begin{tabular}{rrrrrrr} 
& $(0.095)$ & $(0.135)$ & $(0.170)$ & $(0.215)$ & $(0.255)$ & $(0.291)$ \\
\hline
\end{tabular} \begin{tabular}{lllllll} 
& 0.141 & 0.000 & 0.000 & 0.000 & 0.000 & 0.058 \\
\hline & 0.76 & 1.542 & 2.423 & 3.308 & 4.174 & 5.045
\end{tabular} \begin{tabular}{lllllll} 
& 0.736 & 1.542 & 2.423 & 3.308 & 4.174 & 5.045 \\
\hline
\end{tabular} \begin{tabular}{lccccccc} 
Avg.(trade) in countries below cutoff & 0.277 & 0.514 & 0.674 & 1.146 & 1.548 & 2.011 \\
\hline Observations & 700 & 700 & 700 & 700 & 700 & 700
\end{tabular} \begin{tabular}{lllll}
7.984 & 7.984 & 7.984 & 7.984 & 7.984 \\
\hline
\end{tabular} Notes: Robust standard enrors clustered at the country-level in parentheses. ${ }^{*} p<0.1,{ }^{*} p<0.05, * n<<0.01$. IPW estimates. Th the onset of the crisis, scaled prectin treated and control groups are weighted by the propensity scores predicted in the treatment model. Maximum weights truncated at 10. 
Table A.19a: Channels, Cumulative trade losses over five years after debt crises with higher and lower evolution of financial development

\begin{tabular}{|c|c|c|c|c|c|c|c|c|c|c|c|c|c|}
\hline \multicolumn{7}{|c|}{ Panel I: Exports (\% of pre-crisis GDP) } & \multicolumn{7}{|c|}{ Panel II: Imports (\% of pre-crisis GDP) } \\
\hline & (1) & (2) & (3) & (4) & (5) & (6) & & (1) & (2) & (3) & (4) & (5) & (6) \\
\hline & $\mathrm{h}=\mathbf{0}$ & $\mathrm{h}=1$ & $h=2$ & $h=3$ & $h=4$ & $h=5$ & & $\mathrm{~h}=\mathbf{0}$ & $\mathrm{h}=1$ & $h=2$ & $h=3$ & $h=4$ & $h=5$ \\
\hline \multicolumn{7}{|c|}{ Panel A: Debt crises } & \multicolumn{7}{|c|}{ Panel A: Debt crises } \\
\hline \multicolumn{7}{|l|}{ Panel a: Total } & \multicolumn{7}{|l|}{ Panel a: Total } \\
\hline \multirow[t]{2}{*}{ ATE-AIPW High } & $\begin{array}{c}-1.330^{* * *} \\
(0.330)\end{array}$ & $\begin{array}{c}-3.509 * * * \\
(0.434)\end{array}$ & $\begin{array}{c}-4.022 * * * \\
(0.602)\end{array}$ & $\begin{array}{c}*-6.209 * * * \\
(0.849)\end{array}$ & $\begin{array}{c}-5.852 * * * \\
(1.066)\end{array}$ & $\begin{array}{c}-4.147 * * * \\
(1.356)\end{array}$ & \multirow[t]{2}{*}{ ATE-AIPW High } & $\begin{array}{c}-3.726 * * * \\
(0.464)\end{array}$ & $\begin{array}{c}-6.091^{* * *} \\
(0.644)\end{array}$ & $\begin{array}{c}-5.929 * * * \\
(0.962)\end{array}$ & $\begin{array}{c}-6.136 * * * \\
(1.227)\end{array}$ & $\begin{array}{c}-6.831 * * * \\
(1.528)\end{array}$ & $\begin{array}{l}-3.282 \\
(2.021)\end{array}$ \\
\hline & $\begin{array}{c}-1.688^{* * * *} \\
(0.277) \\
\end{array}$ & $\begin{array}{c}-1.924 * * * \\
(0.402) \\
\end{array}$ & $\begin{array}{c}-3.107 * * * \\
(0.555)\end{array}$ & $\begin{array}{c}-6.051 * * * \\
(0.699) \\
\end{array}$ & $\begin{array}{c}-6.711 * * * \\
(0.874) \\
\end{array}$ & $\begin{array}{c}-7.029 * * * \\
(1.057) \\
\end{array}$ & & $\begin{array}{c}-2.995 * * * \\
(0.378) \\
\end{array}$ & $\begin{array}{c}-4.646^{* * *} \\
(0.598)\end{array}$ & $\begin{array}{c}-5.097 * * * \\
(0.863) \\
\end{array}$ & $\begin{array}{c}-6.569 * * * \\
(1.057) \\
\end{array}$ & $\begin{array}{c}-7.457 * * * \\
(1.302) \\
\end{array}$ & $\begin{array}{c}-11.367 * * * \\
(1.550) \\
\end{array}$ \\
\hline P-value High=Low & 0.153 & 0.000 & 0.001 & 0.753 & 0.179 & 0.001 & P-value High=Low & 0.013 & 0.000 & 0.098 & 0.533 & 0.470 & 0.000 \\
\hline Avg.(trade) in countries above cutoff & 3.150 & 6.576 & 10.282 & 14.141 & 17.839 & 21.941 & Avg.(trade) in countries above cutoff & 3.934 & 8.125 & 12.488 & 17.125 & 21.423 & 26.126 \\
\hline Avg.(trade) in countries below cutoff & 2.338 & 4.155 & 6.369 & 8.905 & 10.716 & 12.419 & Avg.(trade) in countries below cutoff & 2.346 & 4.351 & 6.563 & 9.195 & 12.348 & 15.096 \\
\hline \multicolumn{7}{|l|}{ Panel b: Agriculture } & \multicolumn{7}{|l|}{ Panel b: Agriculture } \\
\hline \multirow[t]{2}{*}{ ATE-AIPW High } & $\begin{array}{c}0.045 \\
(0.102)\end{array}$ & $\begin{array}{l}0.262^{*} \\
(0.135)\end{array}$ & $\begin{array}{c}0.742 * * * \\
(0.179)\end{array}$ & $\begin{array}{c}1.197 * * * \\
(0.278)\end{array}$ & $\begin{array}{c}1.675^{* * *} \\
(0.388)\end{array}$ & $\begin{array}{c}3.322^{* * *} \\
(0.635)\end{array}$ & \multirow[t]{2}{*}{ ATE-AIPW High } & $\begin{array}{c}-0.438^{* * * *} \\
(0.079)\end{array}$ & $\begin{array}{c}-0.497 * * * \\
(0.081)\end{array}$ & $\begin{array}{c}-0.642^{* * * *} \\
(0.128)\end{array}$ & $\begin{array}{c}-0.804 * * * \\
(0.134)\end{array}$ & $\begin{array}{c}-1.036^{* * * *} \\
(0.157)\end{array}$ & $\begin{array}{c}-0.603^{* * *} \\
(0.194)\end{array}$ \\
\hline & $\begin{array}{c}-0.665 * * * \\
(0.110) \\
\end{array}$ & $\begin{array}{c}-0.222 * * \\
(0.095) \\
\end{array}$ & $\begin{array}{c}-0.418 * * * \\
(0.139)\end{array}$ & $\begin{array}{c}* 0.686 * * * \\
(0.163) \\
\end{array}$ & $\begin{array}{c}-0.738 * * * \\
(0.197) \\
\end{array}$ & $\begin{array}{l}-0.243 \\
(0.215) \\
\end{array}$ & & $\begin{array}{c}0.018 \\
(0.064)\end{array}$ & $\begin{array}{c}-0.657 * * * \\
(0.079)\end{array}$ & $\begin{array}{c}-0.329 * * * \\
(0.120)\end{array}$ & $\begin{array}{c}-0.681 * * * \\
(0.123)\end{array}$ & $\begin{array}{c}-0.827 * * * \\
(0.146)\end{array}$ & $\begin{array}{c}-1.004 * * * \\
(0.174) \\
\end{array}$ \\
\hline P-value High=Low & 0.000 & 0.000 & 0.000 & 0.000 & 0.000 & 0.000 & P-value High=Low & 0.000 & 0.000 & 0.000 & 0.043 & 0.002 & 0.000 \\
\hline Avg.(trade) in countries above cutoff & 0.400 & 0.822 & 1.319 & 1.783 & 2.225 & 2.779 & Avg.(trade) in countries above cutoff & 0.355 & 0.720 & 1.117 & 1.561 & 1.970 & 2.440 \\
\hline Avg.(trade) in countries below cutoff & 0.312 & 0.616 & 0.932 & 1.420 & 1.786 & 2.220 & Avg.(trade) in countries below cutoff & 0.249 & 0.527 & 0.781 & 1.059 & 1.422 & 1.709 \\
\hline \multicolumn{7}{|l|}{ Panel c: Mining } & \multicolumn{7}{|l|}{ Panel c: Mining } \\
\hline ATE-AIPW High & $\begin{array}{c}0.113 \\
(0.209)\end{array}$ & $\begin{array}{l}-0.273 \\
(0.223)\end{array}$ & $\begin{array}{l}-0.338 \\
(0.256)\end{array}$ & $\begin{array}{c}-1.314 * * * \\
(0.350)\end{array}$ & $\begin{array}{l}-0.070 \\
(0.411)\end{array}$ & $\begin{array}{l}1.207^{* *} \\
(0.558)\end{array}$ & \multirow[t]{2}{*}{ ATE-AIPW High } & $\begin{array}{c}-0.281 * * * \\
(0.091)\end{array}$ & $\begin{array}{c}-0.750^{* * *} \\
(0.144)\end{array}$ & $\begin{array}{c}-0.659 * * * \\
(0.199)\end{array}$ & $\begin{array}{c}-0.967^{* * * *} \\
(0.282)\end{array}$ & $\begin{array}{c}-1.037 * * * \\
(0.359)\end{array}$ & $\begin{array}{l}-0.070 \\
(0.466)\end{array}$ \\
\hline ATE-AIPW Low & $\begin{array}{l}-0.049 \\
(0.107)\end{array}$ & $\begin{array}{l}-0.118 \\
(0.155)\end{array}$ & $\begin{array}{c}-0.646^{* * *} \\
(0.215)\end{array}$ & $\begin{array}{c}* 1.597 * * * \\
(0.265) \\
\end{array}$ & $\begin{array}{c}-2.032 * * * \\
(0.324) \\
\end{array}$ & $\begin{array}{c}-2.266^{* * * *} \\
(0.384) \\
\end{array}$ & & $\begin{array}{c}-0.644^{* * * *} \\
(0.087)\end{array}$ & $\begin{array}{l}-0.007 \\
(0.168) \\
\end{array}$ & $\begin{array}{c}-0.693 * * * \\
(0.213)\end{array}$ & $\begin{array}{c}-1.345^{* * * *} \\
(0.263)\end{array}$ & $\begin{array}{c}-1.511 * * * \\
(0.323)\end{array}$ & $\begin{array}{c}-2.662 * * * \\
(0.380) \\
\end{array}$ \\
\hline P-value High=Low & 0.372 & 0.356 & 0.037 & 0.225 & 0.000 & 0.000 & P-value High=Low & 0.000 & 0.000 & 0.810 & 0.038 & 0.009 & 0.000 \\
\hline Avg.(trade) in countries above cutoff & 0.577 & 1.166 & 1.863 & 2.598 & 3.304 & 4.039 & Avg.(trade) in countries above cutoff & 0.662 & 1.394 & 2.175 & 2.972 & 3.649 & 4.457 \\
\hline Avg.(trade) in countries below cutoff & 0.297 & 0.633 & 0.917 & 1.266 & 1.323 & 1.269 & Avg.(trade) in countries below cutoff & 0.334 & 0.658 & 1.041 & 1.554 & 1.997 & 2.018 \\
\hline \multicolumn{7}{|l|}{ Panel d: Manufacturing } & \multicolumn{7}{|l|}{ Panel d: Manufacturing } \\
\hline ATE-AIPW High & $\begin{array}{c}-0.958 * * * \\
(0.136)\end{array}$ & $\begin{array}{c}-2.107 * * * \\
(0.227)\end{array}$ & $\begin{array}{c}-2.691 * * * \\
(0.315)\end{array}$ & $\begin{array}{c}-3.832 * * * \\
(0.407)\end{array}$ & $\begin{array}{c}-4.828 * * * \\
(0.512)\end{array}$ & $\begin{array}{c}-5.195^{* * *} \\
(0.619)\end{array}$ & ATE-AIPW High & $\begin{array}{c}-2.031 * * * \\
(0.283)\end{array}$ & $\begin{array}{c}-3.310^{* * *} \\
(0.392)\end{array}$ & $\begin{array}{c}-2.649 * * * \\
(0.578)\end{array}$ & $\begin{array}{c}-2.357 * * * \\
(0.748)\end{array}$ & $\begin{array}{c}-2.630^{* * * *} \\
(0.954)\end{array}$ & $\begin{array}{l}-0.742 \\
(1.291)\end{array}$ \\
\hline ATE-AIPW Low & $\begin{array}{c}-0.701 * * * \\
(0.142)\end{array}$ & $\begin{array}{c}-0.786 * * * \\
(0.235)\end{array}$ & $\begin{array}{c}-1.714 * * * \\
(0.316)\end{array}$ & $\begin{array}{c}-3.129 * * * \\
(0.405)\end{array}$ & $\begin{array}{c}-3.562 * * * \\
(0.505)\end{array}$ & $\begin{array}{c}-4.017^{* * *} \\
(0.608)\end{array}$ & ATE-AIPW Low & $\begin{array}{c}-1.988 * * * \\
(0.232)\end{array}$ & $\begin{array}{c}-3.492 * * * \\
(0.359)\end{array}$ & $\begin{array}{c}-3.546 * * * \\
(0.509)\end{array}$ & $\begin{array}{c}-3.969 * * * \\
(0.610)\end{array}$ & $\begin{array}{c}-4.441 * * * \\
(0.747)\end{array}$ & $\begin{array}{c}-6.536^{* * *} \\
(0.880)\end{array}$ \\
\hline P-value High=Low & 0.000 & 0.000 & 0.000 & 0.000 & 0.000 & 0.000 & P-value High=Low & 0.818 & 0.426 & 0.004 & 0.001 & 0.005 & 0.000 \\
\hline Avg.(trade) in countries above cutoff & 1.361 & 2.889 & 4.392 & 6.009 & 7.542 & 9.202 & Avg.(trade) in countries above cutoff & 2.287 & 4.671 & 7.090 & 9.619 & 12.048 & 14.642 \\
\hline Avg.(trade) in countries below cutoff & 0.935 & 1.534 & 2.561 & 3.588 & 4.383 & 5.257 & Avg.(trade) in countries below cutoff & 1.245 & 2.255 & 3.521 & 4.966 & 6.834 & 8.824 \\
\hline \multicolumn{7}{|l|}{ Panel e: Services } & Panel e: Services & & & & & & \\
\hline ATE-AIPW High & $\begin{array}{c}-0.530^{* * *} \\
(0.080)\end{array}$ & $\begin{array}{c}-1.391^{* * * *} \\
(0.135)\end{array}$ & $\begin{array}{c}-1.735^{* * * *} \\
(0.196)\end{array}$ & $\begin{array}{c}-2.259^{* * *} \\
(0.250)\end{array}$ & $\begin{array}{c}-2.629 * * * \\
(0.294)\end{array}$ & $\begin{array}{c}-3.480^{* * *} \\
(0.353)\end{array}$ & ATE-AIPW High & $\begin{array}{c}-0.976^{* * *} \\
(0.112)\end{array}$ & $\begin{array}{c}-1.534^{* * *} \\
(0.149)\end{array}$ & $\begin{array}{c}-1.979^{* * * *} \\
(0.201)\end{array}$ & $\begin{array}{c}-2.009^{* * * *} \\
(0.229)\end{array}$ & $\begin{array}{c}-2.127 * * * \\
(0.265)\end{array}$ & $\begin{array}{c}-1.867^{* * * *} \\
(0.301)\end{array}$ \\
\hline ATE-AIPW Low & $\begin{array}{c}-0.273 * * * \\
(0.078)\end{array}$ & $\begin{array}{c}-0.798 * * * \\
(0.135)\end{array}$ & $\begin{array}{l}-0.329^{*} \\
(0.183)\end{array}$ & $\begin{array}{c}-0.639 * * * \\
(0.237)\end{array}$ & $\begin{array}{l}-0.379 \\
(0.278)\end{array}$ & $\begin{array}{l}-0.503 \\
(0.334)\end{array}$ & ATE-AIPW Low & $\begin{array}{c}-0.382 * * * \\
(0.085)\end{array}$ & $\begin{array}{c}-0.490^{* * *} \\
(0.119)\end{array}$ & $\begin{array}{c}-0.530^{* * * *} \\
(0.157)\end{array}$ & $\begin{array}{c}-0.574 * * * \\
(0.195)\end{array}$ & $\begin{array}{c}-0.679 * * * \\
(0.227)\end{array}$ & $\begin{array}{c}-1.164^{* * *} \\
(0.267)\end{array}$ \\
\hline P-value High=Low & 0.000 & 0.000 & 0.000 & 0.000 & 0.000 & 0.000 & P-value High=Low & 0.000 & 0.000 & 0.000 & 0.000 & 0.000 & $\frac{0.2000}{0.000}$ \\
\hline Avg.(trade) in countries above cutoff & 0.812 & 1.698 & 2.708 & 3.752 & 4.768 & 5.921 & Avg.(trade) in countries above cutoff & 0.631 & 1.339 & 2.107 & 2.973 & 3.756 & 4.587 \\
\hline Avg.(trade) in countries below cutoff & 0.794 & 1.373 & 1.959 & 2.632 & 3.224 & 3.673 & Avg.(trade) in countries below cutoff & 0.517 & 0.912 & 1.221 & 1.616 & 2.096 & 2.545 \\
\hline Observations & 702 & 702 & 702 & 702 & 702 & 702 & Observations & 702 & 702 & 702 & 702 & 702 & 702 \\
\hline \# of Crises & 18 & 18 & 18 & 18 & 18 & 18 & \# of Crises & 18 & 18 & 18 & 18 & 18 & 18 \\
\hline Cutoff of channel variable, median & -0.008 & -0.008 & -0.008 & -0.008 & -0.008 & -0.008 & Cutoff of channel variable, median & -0.008 & -0.008 & -0.008 & -0.008 & -0.008 & -0.008 \\
\hline
\end{tabular}

CInternational Monetary Fund. Not for Redistribution 
Table A.19b: Channels, Cumulative trade losses over five years after banking crises with higher and lower evolution of financial development

\begin{tabular}{|c|c|c|c|c|c|c|c|c|c|c|c|c|c|}
\hline \multicolumn{7}{|c|}{ Panel I: Exports (\% of pre-crisis GDP) } & \multicolumn{7}{|c|}{ Panel II: Imports (\% of pre-crisis GDP) } \\
\hline & (1) & (2) & (3) & (4) & (5) & (6) & & (1) & (2) & (3) & (4) & (5) & (6) \\
\hline & $\mathrm{h}=\mathbf{0}$ & $\mathrm{h}=1$ & $\mathrm{~h}=\mathbf{2}$ & $h=3$ & $h=4$ & $h=5$ & & $\mathrm{~h}=\mathbf{0}$ & $\mathrm{h}=\mathbf{1}$ & $\mathrm{h}=\mathbf{2}$ & $h=3$ & $h=4$ & $h=5$ \\
\hline \multicolumn{7}{|c|}{ Panel B: Banking crises } & \multicolumn{7}{|c|}{ Panel B: Banking crises } \\
\hline Panel a: Total & & & & & & & Panel a: Total & & & & & & \\
\hline ATE-AIPW High & $\begin{array}{c}-2.306 * * * \\
(0.278)\end{array}$ & $\begin{array}{c}*-5.461^{* * * *} \\
(0.473)\end{array}$ & $\begin{array}{c}-6.304 * * * \\
(0.554)\end{array}$ & $\begin{array}{c}*-5.320^{* * * *} \\
(0.696)\end{array}$ & $\begin{array}{c}-5.970^{* * *} \\
(0.878)\end{array}$ & $\begin{array}{c}-5.898^{* * *} \\
(1.082)\end{array}$ & ATE-AIPW High & $\begin{array}{c}-5.496^{* * *} \\
(0.422)\end{array}$ & $\begin{array}{c}-9.162^{* * * *} \\
(0.727)\end{array}$ & $\begin{array}{c}-9.787 * * * \\
(0.851)\end{array}$ & $\begin{array}{c}-8.626^{* * * *} \\
(1.001)\end{array}$ & $\begin{array}{c}-7.680^{* * * *} \\
(1.266)\end{array}$ & $\begin{array}{c}-8.499 * * * \\
(1.521)\end{array}$ \\
\hline ATE-AIPW Low & $\begin{array}{c}-0.014 \\
(0.305)\end{array}$ & $\begin{array}{c}-5.316^{* * * *} \\
(0.475)\end{array}$ & $\begin{array}{c}-5.057 * * * \\
(0.567)\end{array}$ & $\begin{array}{c}*-5.012 * * * \\
(0.701)\end{array}$ & $\begin{array}{c}-9.209^{* * *} \\
(0.858)\end{array}$ & $\begin{array}{c}-9.637^{* * *} \\
(1.059)\end{array}$ & ATE-AIPW Low & $\begin{array}{l}-0.131 \\
(0.398)\end{array}$ & $\begin{array}{c}-8.313 * * * \\
(0.695)\end{array}$ & $\begin{array}{c}-9.721 * * * \\
(0.837)\end{array}$ & $\begin{array}{c}-10.532 * * * \\
(0.946)\end{array}$ & $\begin{array}{c}-14.917 * * * \\
(1.202)\end{array}$ & $\begin{array}{c}-16.622 * * * \\
(1.469)\end{array}$ \\
\hline P-value High=Low & 0.000 & 0.535 & 0.000 & 0.409 & 0.000 & 0.000 & P-value High=Low & 0.000 & 0.073 & 0.887 & 0.000 & 0.000 & 0.000 \\
\hline Avg.(trade) in countries above cutoff & 3.591 & 7.423 & 11.452 & 15.652 & 19.711 & 24.007 & Avg.(trade) in countries above cutoff & 4.294 & 9.036 & 13.876 & 18.734 & 23.349 & 28.106 \\
\hline Avg.(trade) in countries below cutoff & 1.895 & 3.640 & 5.876 & 8.340 & 10.264 & 12.566 & Avg.(trade) in countries below cutoff & 2.345 & 4.250 & 6.480 & 9.508 & 12.560 & 15.974 \\
\hline \multicolumn{7}{|l|}{ Panel b: Agriculture } & \multicolumn{7}{|l|}{ Panel b: Agriculture } \\
\hline ATE-AIPW High & $\begin{array}{c}-0.221^{* * * *} \\
(0.063)\end{array}$ & $\begin{array}{c}*-0.674^{* * * *} \\
(0.087)\end{array}$ & $\begin{array}{c}-0.696^{* * *} \\
(0.119)\end{array}$ & $\begin{array}{c}-0.689^{* * * *} \\
(0.148)\end{array}$ & $\begin{array}{c}-0.764 * * * \\
(0.170)\end{array}$ & $\begin{array}{c}-0.883^{* * *} \\
(0.204)\end{array}$ & ATE-AIPW High & $\begin{array}{c}-0.724 * * * \\
(0.056)\end{array}$ & $\begin{array}{c}-0.773^{* * *} \\
(0.087)\end{array}$ & $\begin{array}{c}-0.892 * * * \\
(0.102)\end{array}$ & $\begin{array}{c}-0.937^{* * *} \\
(0.112)\end{array}$ & $\begin{array}{c}-0.854^{* * * *} \\
(0.145)\end{array}$ & $\begin{array}{c}-1.083^{* * * *} \\
(0.167)\end{array}$ \\
\hline ATE-AIPW Low & $\begin{array}{c}0.171 * * * \\
(0.058)\end{array}$ & $\begin{array}{r}-0.185^{* *} \\
(0.086)\end{array}$ & $\begin{array}{c}-0.404 * * * \\
(0.112)\end{array}$ & $\begin{array}{c}{ }^{*}-0.626^{* * * *} \\
(0.132)\end{array}$ & $\begin{array}{c}-0.822 * * * \\
(0.160)\end{array}$ & $\begin{array}{c}-1.433^{* * * *} \\
(0.185)\end{array}$ & ATE-AIPW Low & $\begin{array}{c}0.048 \\
(0.061)\end{array}$ & $\begin{array}{c}-0.246 * * \\
(0.098)\end{array}$ & $\begin{array}{c}-0.348^{* * * *} \\
(0.110)\end{array}$ & $\begin{array}{c}-0.709 * * * \\
(0.115)\end{array}$ & $\begin{array}{c}-1.383 * * * \\
(0.132)\end{array}$ & $\begin{array}{c}-1.629 * * * \\
(0.162)\end{array}$ \\
\hline P-value High=Low & 0.000 & 0.000 & 0.002 & 0.557 & 0.649 & 0.000 & P-value High=Low & 0.000 & 0.000 & 0.000 & 0.001 & 0.000 & 0.000 \\
\hline Avg.(trade) in countries above cutoff & 0.429 & 0.890 & 1.378 & 1.835 & 2.334 & 2.927 & Avg.(trade) in countries above cutoff & 0.374 & 0.793 & 1.246 & 1.737 & 2.169 & 2.638 \\
\hline Avg.(trade) in countries below cutoff & 0.296 & 0.580 & 0.980 & 1.472 & 1.769 & 2.182 & Avg.(trade) in countries below cutoff & 0.257 & 0.477 & 0.688 & 0.952 & 1.293 & 1.651 \\
\hline \multicolumn{7}{|l|}{ Panel c: Mining } & \multicolumn{7}{|l|}{ Panel c: Mining } \\
\hline ATE-AIPW High & $\begin{array}{l}-0.274 \\
(0.167)\end{array}$ & $\begin{array}{c}-1.332^{* * * *} \\
(0.223)\end{array}$ & $\begin{array}{c}-1.537 * * * \\
(0.240)\end{array}$ & $\begin{array}{c}-1.705^{* * * *} \\
(0.292)\end{array}$ & $\begin{array}{c}-2.237 * * * \\
(0.358)\end{array}$ & $\begin{array}{c}-2.542^{* * *} \\
(0.428)\end{array}$ & ATE-AIPW High & $\begin{array}{c}-0.976^{* * *} \\
(0.094)\end{array}$ & $\begin{array}{c}-1.524^{* * *} \\
(0.146)\end{array}$ & $\begin{array}{c}-1.861 * * * \\
(0.169)\end{array}$ & $\begin{array}{c}-2.005^{* * * *} \\
(0.199)\end{array}$ & $\begin{array}{c}-2.203^{* * * *} \\
(0.252)\end{array}$ & $\begin{array}{c}-2.723^{* * *} \\
(0.308)\end{array}$ \\
\hline ATE-AIPW Low & $\begin{array}{l}-0.269^{*} \\
(0.143)\end{array}$ & $\begin{array}{c}-0.902 * * * \\
(0.226)\end{array}$ & $\begin{array}{c}-0.794 * * * \\
(0.258)\end{array}$ & $\begin{array}{c}-1.079 * * * * \\
(0.282)\end{array}$ & $\begin{array}{c}-2.342 * * * \\
(0.327)\end{array}$ & $\begin{array}{c}-0.802^{*} \\
(0.461)\end{array}$ & ATE-AIPW Low & $\begin{array}{c}-0.204 * * \\
(0.101)\end{array}$ & $\begin{array}{c}-1.578^{* * *} \\
(0.151)\end{array}$ & $\begin{array}{c}-1.605^{* * *} \\
(0.169)\end{array}$ & $\begin{array}{c}-1.463^{* * * *} \\
(0.206)\end{array}$ & $\begin{array}{c}-2.098 * * * \\
(0.250)\end{array}$ & $\begin{array}{c}-2.636 * * * \\
(0.300)\end{array}$ \\
\hline P-value High=Low & 0.953 & 0.000 & 0.000 & 0.000 & 0.492 & 0.000 & P-value High=Low & 0.000 & 0.398 & 0.000 & 0.000 & 0.318 & 0.469 \\
\hline Avg.(trade) in countries above cutoff & 0.671 & 1.270 & 2.107 & 2.972 & 3.751 & 4.520 & Avg.(trade) in countries above cutoff & 0.690 & 1.483 & 2.341 & 3.161 & 3.903 & 4.751 \\
\hline Avg.(trade) in countries below cutoff & 0.244 & 0.662 & 0.864 & 1.139 & 1.325 & 1.519 & Avg.(trade) in countries below cutoff & 0.412 & 0.791 & 1.197 & 1.779 & 2.202 & 2.460 \\
\hline \multicolumn{7}{|l|}{ Panel d: Manufacturing } & \multicolumn{7}{|l|}{ Panel d: Manufacturing } \\
\hline ATE-AIPW High & $\begin{array}{c}-0.709^{* * * *} \\
(0.126)\end{array}$ & $\begin{array}{c}*-1.461 * * * \\
(0.229)\end{array}$ & $\begin{array}{c}-1.967 * * * \\
(0.307)\end{array}$ & $\begin{array}{c}-1.295^{* * * *} \\
(0.417)\end{array}$ & $\begin{array}{c}-0.965^{*} \\
(0.530)\end{array}$ & $\begin{array}{c}-1.065^{*} \\
(0.624)\end{array}$ & ATE-AIPW High & $\begin{array}{c}-2.825 * * * \\
(0.252)\end{array}$ & $\begin{array}{c}-5.402 * * * \\
(0.445)\end{array}$ & $\begin{array}{c}-5.341 * * * \\
(0.519)\end{array}$ & $\begin{array}{c}-4.256^{* * * *} \\
(0.606)\end{array}$ & $\begin{array}{c}-2.897 * * * \\
(0.774)\end{array}$ & $\begin{array}{c}-3.075 * * * \\
(0.928)\end{array}$ \\
\hline ATE-AIPW Low & $\begin{array}{l}0.351^{* *} \\
(0.169)\end{array}$ & $\begin{array}{c}-2.218 * * * \\
(0.292)\end{array}$ & $\begin{array}{c}-1.257 * * * \\
(0.378)\end{array}$ & $\begin{array}{l}-0.543 \\
(0.465)\end{array}$ & $\begin{array}{c}-2.244^{* * *} \\
(0.526)\end{array}$ & $\begin{array}{c}-2.308^{* * * *} \\
(0.674)\end{array}$ & ATE-AIPW Low & $\begin{array}{l}-0.327 \\
(0.231)\end{array}$ & $\begin{array}{c}-5.505^{* * *} \\
(0.417)\end{array}$ & $\begin{array}{c}-5.886^{* * *} \\
(0.501)\end{array}$ & $\begin{array}{c}-6.033 * * * \\
(0.565)\end{array}$ & $\begin{array}{c}-8.596 * * * \\
(0.716)\end{array}$ & $\begin{array}{c}-9.124^{* * *} \\
(0.883)\end{array}$ \\
\hline P-value High=Low & 0.000 & 0.000 & 0.006 & 0.026 & 0.000 & 0.008 & P-value High=Low & 0.000 & 0.751 & 0.084 & 0.000 & 0.000 & 0.000 \\
\hline Avg.(trade) in countries above cutoff & 1.519 & 3.256 & 4.845 & 6.576 & 8.259 & 9.971 & Avg.(trade) in countries above cutoff & 2.530 & 5.233 & 7.899 & 10.521 & 13.122 & 15.688 \\
\hline Avg.(trade) in countries below cutoff & 0.829 & 1.430 & 2.494 & 3.553 & 4.375 & 5.467 & Avg.(trade) in countries below cutoff & 1.232 & 2.228 & 3.517 & 5.222 & 7.013 & 9.286 \\
\hline \multicolumn{7}{|l|}{ Panel e: Services } & \multicolumn{7}{|l|}{ Panel e: Services } \\
\hline ATE-AIPW High & $\begin{array}{c}-1.101^{* * * *} \\
(0.092)\end{array}$ & $\begin{array}{c}*-1.993 * * * \\
(0.144)\end{array}$ & $\begin{array}{c}-2.104 * * * \\
(0.194)\end{array}$ & $\begin{array}{c}-1.631 * * * \\
(0.271)\end{array}$ & $\begin{array}{c}-2.003^{* * *} \\
(0.336)\end{array}$ & $\begin{array}{c}-1.408 * * * \\
(0.460)\end{array}$ & ATE-AIPW High & $\begin{array}{c}-0.971 * * * \\
(0.087)\end{array}$ & $\begin{array}{c}-1.463^{* * * *} \\
(0.134)\end{array}$ & $\begin{array}{c}-1.693 * * * \\
(0.167)\end{array}$ & $\begin{array}{c}-1.428^{* * * *} \\
(0.203)\end{array}$ & $\begin{array}{c}-1.726^{* * * *} \\
(0.237)\end{array}$ & $\begin{array}{c}-1.619^{* * * *} \\
(0.271)\end{array}$ \\
\hline ATE-AIPW Low & $\begin{array}{c}-0.267 * * * \\
(0.090)\end{array}$ & $\begin{array}{c}*-2.011 * * * \\
(0.157)\end{array}$ & $\begin{array}{c}-2.602 * * * \\
(0.224)\end{array}$ & $\begin{array}{l}-2.764 * * * \\
(0.288)\end{array}$ & $\begin{array}{c}-3.802 * * * \\
(0.353)\end{array}$ & $\begin{array}{c}-5.093 * * * \\
(0.412)\end{array}$ & ATE-AIPW Low & $\begin{array}{c}0.353 * * * \\
(0.089)\end{array}$ & $\begin{array}{c}-0.984 * * * \\
(0.115)\end{array}$ & $\begin{array}{c}-1.882 * * * \\
(0.167)\end{array}$ & $\begin{array}{c}-2.327 * * * \\
(0.198)\end{array}$ & $\begin{array}{c}-2.841^{* * *} \\
(0.240)\end{array}$ & $\begin{array}{c}-3.232 * * * \\
(0.281)\end{array}$ \\
\hline P-value High=Low & 0.000 & 0.870 & 0.001 & 0.000 & 0.000 & 0.000 & P-value High=Low & 0.000 & 0.000 & 0.121 & 0.000 & 0.000 & 0.000 \\
\hline Avg.(trade) in countries above cutoff & 0.972 & 2.007 & 3.121 & 4.269 & 5.367 & & Avg.(trade) in countries above cutoff & 0.699 & 1.527 & 2.390 & 3.314 & 4.156 & 5.029 \\
\hline Avg.(trade) in countries below cutoff & 0.526 & 0.968 & 1.538 & 2.177 & 2.795 & 3.397 & Avg.(trade) in countries below cutoff & 0.444 & 0.754 & 1.078 & 1.555 & 2.052 & 2.577 \\
\hline Observations & 705 & 705 & 705 & 705 & 705 & 705 & Observations & 705 & 705 & 705 & 705 & 705 & 705 \\
\hline \# of Crises & 17 & 17 & 17 & 17 & 17 & 17 & \# of Crises & 17 & 17 & 17 & 17 & 17 & 17 \\
\hline Cutoff of channel variable, median & 0.006 & 0.006 & 0.006 & 0.006 & 0.006 & 0.006 & Cutoff of channel variable, median & 0.006 & 0.006 & 0.006 & 0.006 & 0.006 & 0.006 \\
\hline
\end{tabular}


Table A.19c: Channels, Cumulative trade losses over five years after currency crises with higher and lower evolution of financial development

\begin{tabular}{|c|c|c|c|c|c|c|c|c|c|c|c|c|c|}
\hline \multicolumn{7}{|c|}{ Panel I: Exports (\% of pre-crisis GDP) } & \multicolumn{7}{|c|}{ Panel II: Imports (\% of pre-crisis GDP) } \\
\hline & (1) & (2) & (3) & (4) & (5) & (6) & & (1) & (2) & (3) & (4) & (5) & (6) \\
\hline & $\mathrm{h}=\mathbf{0}$ & $\mathrm{h}=1$ & $\mathrm{~h}=\mathbf{2}$ & $h=3$ & $h=4$ & $h=5$ & & $\mathrm{~h}=\mathbf{0}$ & $\mathrm{h}=\mathbf{1}$ & $\mathrm{h}=\mathbf{2}$ & $\mathrm{h}=\mathbf{3}$ & $h=4$ & $h=5$ \\
\hline \multirow{2}{*}{\multicolumn{7}{|c|}{ Panel C: Currency crises }} & \multicolumn{7}{|c|}{ Panel C: Currency crises } \\
\hline Panel a: Total & & & & & & & Panel a: Total & & & & & & \\
\hline ATE-AIPW High & $\begin{array}{c}-1.746 * * * \\
(0.286)\end{array}$ & $\begin{array}{c}*-2.530 * * * \\
(0.407)\end{array}$ & $\begin{array}{c}-3.852 * * * \\
(0.583)\end{array}$ & $\begin{array}{c}*-4.669 * * * \\
(0.755)\end{array}$ & $\begin{array}{c}-6.155 * * * \\
(0.864)\end{array}$ & $\begin{array}{c}-7.517^{* * * *} \\
(1.100)\end{array}$ & ATE-AIPW High & $\begin{array}{c}-4.780 * * * \\
(0.413)\end{array}$ & $\begin{array}{c}-6.537 * * * \\
(0.546)\end{array}$ & $\begin{array}{c}-7.660 * * * \\
(0.780)\end{array}$ & $\begin{array}{c}-8.646 * * * \\
(1.015)\end{array}$ & $\begin{array}{c}-9.468^{* * *} \\
(1.236)\end{array}$ & $\begin{array}{c}-8.439 * * * \\
(1.578)\end{array}$ \\
\hline ATE-AIPW Low & $\begin{array}{c}-3.067 * * * \\
(0.384)\end{array}$ & $\begin{array}{c}*-4.724 * * * \\
(0.426)\end{array}$ & $\begin{array}{c}-4.861 * * * \\
(0.568)\end{array}$ & $\begin{array}{c}*-5.566 * * * \\
(0.714)\end{array}$ & $\begin{array}{c}-7.669 * * * \\
(0.830)\end{array}$ & $\begin{array}{c}-9.094 * * * \\
(1.004)\end{array}$ & ATE-AIPW Low & $\begin{array}{c}-6.698 * * * \\
(0.523)\end{array}$ & $\begin{array}{c}-8.322 * * * \\
(0.625)\end{array}$ & $\begin{array}{c}-9.583 * * * \\
(0.839)\end{array}$ & $\begin{array}{c}-10.429^{* * *} \\
\quad(1.014)\end{array}$ & $\begin{array}{c}*-10.760^{* * * *} \\
(1.222)\end{array}$ & $\begin{array}{c}-11.804 * * * \\
(1.454)\end{array}$ \\
\hline P-value High=Low & 0.000 & 0.000 & 0.010 & 0.054 & 0.004 & 0.039 & P-value High=Low & 0.000 & 0.000 & 0.000 & 0.001 & 0.049 & 0.002 \\
\hline Avg.(trade) in countries above cutoff & 3.157 & 6.498 & 10.061 & 13.818 & 17.344 & 21.302 & Avg.(trade) in countries above cutoff & 3.949 & 8.017 & 12.196 & 16.687 & 20.890 & 25.421 \\
\hline Avg.(trade) in countries below cutoff & 2.126 & 3.955 & 6.467 & 9.158 & 11.308 & 13.106 & Avg.(trade) in countries below cutoff & 1.922 & 3.976 & 6.522 & 9.347 & 12.662 & 15.733 \\
\hline \multicolumn{7}{|l|}{ Panel b: Agriculture } & \multicolumn{7}{|l|}{ Panel b: Agriculture } \\
\hline ATE-AIPW High & $\begin{array}{l}-0.009 \\
(0.059)\end{array}$ & $\begin{array}{l}-0.041 \\
(0.106)\end{array}$ & $\begin{array}{l}0.393^{*} \\
(0.216)\end{array}$ & $\begin{array}{c}0.130 \\
(0.227)\end{array}$ & $\begin{array}{c}-0.294 \\
(0.217)\end{array}$ & $\begin{array}{l}-0.498^{*} \\
(0.272)\end{array}$ & ATE-AIPW High & $\begin{array}{c}-0.533 * * * \\
(0.083)\end{array}$ & $\begin{array}{c}-0.498^{* * *} \\
(0.074)\end{array}$ & $\begin{array}{c}-0.562^{* * * *} \\
(0.101)\end{array}$ & $\begin{array}{c}-0.917 * * * \\
(0.112)\end{array}$ & $\begin{array}{c}-0.843 * * * \\
(0.140)\end{array}$ & $\begin{array}{c}-0.708^{* * *} \\
(0.172)\end{array}$ \\
\hline ATE-AIPW Low & $\begin{array}{c}0.060 \\
(0.076)\end{array}$ & $\begin{array}{c}-0.479 * * * \\
(0.090)\end{array}$ & $\begin{array}{c}-0.292 * * \\
(0.120)\end{array}$ & $\begin{array}{l}-0.290^{*} \\
(0.148)\end{array}$ & $\begin{array}{c}-0.008 \\
(0.170)\end{array}$ & $\begin{array}{c}0.054 \\
(0.225)\end{array}$ & ATE-AIPW Low & $\begin{array}{c}-0.502 * * * \\
(0.082)\end{array}$ & $\begin{array}{c}-0.601 * * * \\
(0.077)\end{array}$ & $\begin{array}{c}{ }^{*}-0.890^{* * * *} \\
(0.105)\end{array}$ & $\begin{array}{c}-0.909 * * * \\
(0.114)\end{array}$ & $\begin{array}{c}-0.749 * * * \\
(0.138)\end{array}$ & $\begin{array}{c}-0.821^{* * *} \\
(0.153)\end{array}$ \\
\hline P-value High=Low & 0.282 & 0.000 & 0.001 & 0.039 & 0.087 & 0.016 & P-value High=Low & 0.393 & 0.029 & 0.000 & 0.874 & 0.155 & 0.351 \\
\hline Avg.(trade) in countries above cutoff & 0.400 & 0.821 & 1.313 & 1.773 & 2.200 & 2.735 & Avg.(trade) in countries above cutoff & 0.358 & 0.718 & 1.105 & 1.536 & 1.934 & 2.384 \\
\hline Avg.(trade) in countries below cutoff & 0.290 & 0.573 & 0.868 & 1.383 & 1.796 & 2.290 & Avg.(trade) in countries below cutoff & 0.211 & 0.495 & 0.756 & 1.060 & 1.457 & 1.792 \\
\hline \multicolumn{7}{|l|}{ Panel c: Mining } & \multicolumn{7}{|l|}{ Panel c: Mining } \\
\hline ATE-AIPW High & $\begin{array}{c}-0.401^{* *} \\
(0.180)\end{array}$ & $\begin{array}{c}-0.785^{* * * *} \\
(0.153)\end{array}$ & $\begin{array}{c}-1.102 * * * \\
(0.210)\end{array}$ & $\begin{array}{c}-1.406^{* * * *} \\
(0.268)\end{array}$ & $\begin{array}{c}-1.856^{* * *} \\
(0.321)\end{array}$ & $\begin{array}{c}-2.017 * * * \\
(0.395)\end{array}$ & ATE-AIPW High & $\begin{array}{c}-0.695 * * * \\
(0.078)\end{array}$ & $\begin{array}{c}-0.984 * * * \\
(0.128)\end{array}$ & $\begin{array}{c}-1.313^{* * * *} \\
(0.162)\end{array}$ & $\begin{array}{c}-1.605^{* * *} \\
(0.218)\end{array}$ & $\begin{array}{c}-1.959^{* * *} \\
(0.255)\end{array}$ & $\begin{array}{c}-1.679^{* * *} \\
(0.352)\end{array}$ \\
\hline ATE-AIPW Low & $\begin{array}{c}-0.417^{* *} \\
(0.198)\end{array}$ & $\begin{array}{c}-1.181 * * * \\
(0.178)\end{array}$ & $\begin{array}{c}-1.408 * * * \\
(0.265)\end{array}$ & $\begin{array}{c}-1.490^{* * * *} \\
(0.293)\end{array}$ & $\begin{array}{c}-2.713 * * * \\
(0.324)\end{array}$ & $\begin{array}{c}-2.721^{* * * *} \\
(0.377)\end{array}$ & ATE-AIPW Low & $\begin{array}{c}-1.511^{* * *} \\
(0.121)\end{array}$ & $\begin{array}{c}-1.807 * * * \\
(0.140)\end{array}$ & $\begin{array}{c}-2.606 * * * \\
(0.199)\end{array}$ & $\begin{array}{c}-3.114^{* * *} \\
(0.220)\end{array}$ & $\begin{array}{c}-3.725 * * * \\
(0.256)\end{array}$ & $\begin{array}{c}-4.008^{* * *} \\
(0.290)\end{array}$ \\
\hline P-value High=Low & 0.857 & 0.000 & 0.094 & 0.625 & 0.000 & 0.001 & P-value High=Low & 0.000 & 0.000 & 0.000 & 0.000 & 0.000 & 0.000 \\
\hline Avg.(trade) in countries above cutoff & 0.565 & 1.149 & 1.808 & 2.503 & 3.167 & 3.876 & Avg.(trade) in countries above cutoff & 0.693 & 1.392 & 2.120 & 2.890 & 3.566 & 4.292 \\
\hline Avg.(trade) in countries below cutoff & 0.289 & 0.590 & 0.946 & 1.385 & 1.483 & 1.366 & Avg.(trade) in countries below cutoff & 0.120 & 0.499 & 1.027 & 1.596 & 1.989 & 2.200 \\
\hline \multicolumn{7}{|l|}{ Panel d: Manufacturing } & \multicolumn{7}{|l|}{ Panel d: Manufacturing } \\
\hline ATE-AIPW High & $\begin{array}{c}-0.554 * * * \\
(0.138)\end{array}$ & $\begin{array}{c}*-1.034 * * * \\
(0.233)\end{array}$ & $\begin{array}{c}-1.955 * * * \\
(0.308)\end{array}$ & $\begin{array}{c}-2.285^{* * * *} \\
(0.416)\end{array}$ & $\begin{array}{c}-2.967 * * * \\
(0.502)\end{array}$ & $\begin{array}{c}-3.105 * * * \\
(0.601)\end{array}$ & ATE-AIPW High & $\begin{array}{c}-2.785 * * * \\
(0.250)\end{array}$ & $\begin{array}{c}-4.159 * * * \\
(0.326)\end{array}$ & $\begin{array}{c}-4.640^{* * * *} \\
(0.459)\end{array}$ & $\begin{array}{c}-4.924^{* * * *} \\
(0.599)\end{array}$ & $\begin{array}{c}-5.384 * * * \\
(0.734)\end{array}$ & $\begin{array}{c}-4.596^{* * *} \\
(0.910)\end{array}$ \\
\hline ATE-AIPW Low & $\begin{array}{c}-1.792 * * * \\
(0.213)\end{array}$ & $\begin{array}{c}*-2.261 * * * \\
(0.250)\end{array}$ & $\begin{array}{c}-2.633 * * * \\
(0.303)\end{array}$ & $\begin{array}{c}-3.120^{* * * *} \\
(0.379)\end{array}$ & $\begin{array}{c}-3.757 * * * \\
(0.473)\end{array}$ & $\begin{array}{c}-4.651^{* * * *} \\
(0.581)\end{array}$ & ATE-AIPW Low & $\begin{array}{c}-3.739 * * * \\
(0.326)\end{array}$ & $\begin{array}{c}-4.501 * * * \\
(0.402)\end{array}$ & $\begin{array}{c}-4.538 * * * \\
(0.507)\end{array}$ & $\begin{array}{c}-4.835^{* * *} \\
(0.606)\end{array}$ & $\begin{array}{c}-4.971^{* * *} \\
(0.737)\end{array}$ & $\begin{array}{c}-5.450^{* * *} \\
(0.889)\end{array}$ \\
\hline P-value High=Low & 0.000 & 0.000 & 0.000 & 0.000 & 0.002 & 0.000 & P-value High=Low & 0.000 & 0.205 & 0.717 & 0.782 & 0.290 & 0.150 \\
\hline Avg.(trade) in countries above cutoff & 1.355 & 2.832 & 4.289 & 5.868 & 7.354 & 8.946 & Avg.(trade) in countries above cutoff & 2.255 & 4.582 & 6.922 & 9.375 & 11.738 & 14.293 \\
\hline Avg.(trade) in countries below cutoff & 0.866 & 1.481 & 2.606 & 3.665 & 4.501 & 5.505 & Avg.(trade) in countries below cutoff & 1.149 & 2.103 & 3.459 & 4.994 & 7.035 & 9.060 \\
\hline \multicolumn{7}{|l|}{ Panel e: Services } & \multicolumn{7}{|l|}{ Panel e: Services } \\
\hline ATE-AIPW High & $\begin{array}{c}-0.782^{* * * *} \\
(0.083)\end{array}$ & $\begin{array}{c}*-0.671^{* * * *} \\
(0.144)\end{array}$ & $\begin{array}{c}-1.188^{* * * *} \\
(0.190)\end{array}$ & $\begin{array}{c}-1.108^{* * *} \\
(0.282)\end{array}$ & $\begin{array}{c}-1.037 * * * \\
(0.322)\end{array}$ & $\begin{array}{c}-1.897 * * * \\
(0.395)\end{array}$ & ATE-AIPW High & $\begin{array}{c}-0.766^{* * *} \\
(0.077)\end{array}$ & $\begin{array}{c}-0.896^{* * * *} \\
(0.118)\end{array}$ & $\begin{array}{c}* 1.145^{* * * *} \\
(0.174)\end{array}$ & $\begin{array}{c}-1.200^{* * * *} \\
(0.221)\end{array}$ & $\begin{array}{c}-1.282 * * * \\
(0.259)\end{array}$ & $\begin{array}{c}-1.456^{* * *} \\
(0.293)\end{array}$ \\
\hline ATE-AIPW Low & $\begin{array}{c}-0.919 * * * \\
(0.085)\end{array}$ & $\begin{array}{c}*-0.802 * * * \\
(0.132)\end{array}$ & $\begin{array}{c}-0.528^{* * *} \\
(0.200)\end{array}$ & $\begin{array}{l}-0.667 * * \\
(0.305)\end{array}$ & $\begin{array}{c}-1.190^{* * *} \\
(0.329)\end{array}$ & $\begin{array}{c}-1.776^{* * *} \\
(0.382)\end{array}$ & ATE-AIPW Low & $\begin{array}{c}-0.945^{* * *} \\
(0.081)\end{array}$ & $\begin{array}{c}-1.413 * * * \\
(0.122)\end{array}$ & $\begin{array}{c}*-1.549 * * * \\
(0.179)\end{array}$ & $\begin{array}{c}-1.572 * * * \\
(0.228)\end{array}$ & $\begin{array}{c}-1.315^{* * *} \\
(0.265)\end{array}$ & $\begin{array}{c}-1.525 * * * \\
(0.300)\end{array}$ \\
\hline P-value High=Low & 0.035 & 0.201 & 0.000 & 0.037 & 0.536 & 0.708 & P-value High=Low & 0.003 & 0.000 & 0.000 & 0.006 & 0.850 & 0.773 \\
\hline Avg.(trade) in countries above cutoff & 0.837 & 1.695 & 2.650 & 3.674 & 4.622 & 5.746 & Avg.(trade) in countries above cutoff & 0.642 & 1.324 & 2.048 & 2.885 & 3.652 & 4.452 \\
\hline Avg.(trade) in countries below cutoff & 0.681 & 1.311 & 2.047 & 2.726 & 3.527 & 3.944 & Avg.(trade) in countries below cutoff & 0.442 & 0.878 & 1.279 & 1.698 & 2.182 & 2.682 \\
\hline Observations & 705 & 705 & 705 & 705 & 705 & 705 & Observations & 705 & 705 & 705 & 705 & 705 & 705 \\
\hline \# of Crises & 18 & 18 & 18 & 18 & 18 & 18 & \# of Crises & 18 & 18 & 18 & 18 & 18 & 18 \\
\hline Cutoff of channel variable, median & -0.015 & -0.015 & -0.015 & -0.015 & -0.015 & -0.015 & Cutoff of channel variable, median & -0.015 & -0.015 & -0.015 & -0.015 & -0.015 & -0.015 \\
\hline
\end{tabular}


Table A.20a: Channels, Cumulative trade losses over five years after debt crises with higher and lower evolution of gross capital inflows

\begin{tabular}{|c|c|c|c|c|c|c|c|c|c|c|c|c|c|}
\hline \multicolumn{7}{|c|}{ Panel I: Exports (\% of pre-crisis GDP) } & \multicolumn{7}{|c|}{ Panel II: Imports (\% of pre-crisis GDP) } \\
\hline & (1) & (2) & (3) & (4) & (5) & (6) & & (1) & (2) & (3) & (4) & (5) & (6) \\
\hline & $\mathrm{h}=\mathbf{0}$ & $\mathrm{h}=1$ & $\mathrm{~h}=2$ & $h=3$ & $h=4$ & $h=5$ & & $\mathbf{h}=\mathbf{0}$ & $\mathrm{h}=1$ & $\mathrm{~h}=\mathbf{2}$ & $h=3$ & $h=4$ & $h=5$ \\
\hline & \\
\hline \multicolumn{7}{|c|}{ Panel A: Debt crises } & Panel A: Debt crises & & & & & & \\
\hline ATE-AIPW High & $\begin{array}{c}-0.284 \\
(0.391)\end{array}$ & $\begin{array}{c}-1.984 * * * \\
(0.551)\end{array}$ & $\begin{array}{c}-2.188 * * * \\
(0.703)\end{array}$ & $\begin{array}{c}-4.005^{* * *} \\
(1.051)\end{array}$ & $\begin{array}{c}-6.220^{* * *} \\
(1.494)\end{array}$ & $\begin{array}{c}-5.370^{* * *} \\
(1.986)\end{array}$ & ATE-AIPW High & $\begin{array}{c}-1.111^{* *} \\
(0.495)\end{array}$ & $\begin{array}{c}-3.563^{* * *} \\
(0.698)\end{array}$ & $\begin{array}{c}-2.538^{* *} \\
(0.985)\end{array}$ & $\begin{array}{c}-3.576^{* *} \\
(1.408)\end{array}$ & $\begin{array}{c}-5.443 * * * \\
(1.918)\end{array}$ & $\begin{array}{c}-5.047 * * \\
(2.531)\end{array}$ \\
\hline ATE-AIPW Low & $\begin{array}{c}-2.969 * * * \\
(0.275)\end{array}$ & $\begin{array}{c}-4.344 * * * \\
(0.474)\end{array}$ & $\begin{array}{c}-6.274 * * * \\
(0.699)\end{array}$ & $\begin{array}{c}-11.091 * * * \\
(1.001)\end{array}$ & $\begin{array}{c}*-11.031 * * * \\
(1.459)\end{array}$ & $\begin{array}{c}-13.326^{* * *} \\
(1.942)\end{array}$ & ATE-AIPW Low & $\begin{array}{c}-7.441 * * * \\
(0.513)\end{array}$ & $\begin{array}{c}-8.027 * * * \\
(0.702)\end{array}$ & $\begin{array}{c}-12.078^{* * *} \\
(0.998)\end{array}$ & $\begin{array}{c}-15.083^{* * *} \\
(1.380)\end{array}$ & $\begin{array}{c}-16.385^{* * *} \\
(1.918)\end{array}$ & $\begin{array}{c}-19.098^{* * * *} \\
(2.494)\end{array}$ \\
\hline P-value High=Low & 0.000 & 0.000 & 0.000 & 0.000 & 0.000 & 0.000 & P-value High=Low & 0.000 & 0.000 & 0.000 & 0.000 & 0.000 & 0.000 \\
\hline Avg.(trade) in countries above cutoff & 3.157 & 6.913 & 10.928 & 15.150 & 18.932 & 22.777 & Avg.(trade) in countries above cutoff & 3.770 & 8.651 & 13.650 & 18.749 & 23.812 & 28.669 \\
\hline Avg.(trade) in countries below cutoff & 2.571 & 4.552 & 6.909 & 9.276 & 11.957 & 14.748 & Avg.(trade) in countries below cutoff & 2.684 & 4.068 & 5.793 & 7.984 & 10.379 & 13.319 \\
\hline \multicolumn{7}{|l|}{ Panel b: Agriculture } & \multicolumn{7}{|l|}{ Panel b: Agriculture } \\
\hline ATE-AIPW High & $\begin{array}{c}-0.606 * * * \\
(0.136)\end{array}$ & $\begin{array}{c}-0.068 \\
(0.122)\end{array}$ & $\begin{array}{c}0.582^{* * * *} \\
(0.194)\end{array}$ & $\begin{array}{c}1.002 * * * \\
(0.313)\end{array}$ & $\begin{array}{l}0.657^{* *} \\
(0.324)\end{array}$ & $\begin{array}{c}0.958^{* * *} \\
(0.301)\end{array}$ & ATE-AIPW High & $\begin{array}{l}-0.096 \\
(0.132)\end{array}$ & $\begin{array}{c}-0.561 * * * \\
(0.130)\end{array}$ & $\begin{array}{c}-0.326^{* *} \\
(0.129)\end{array}$ & $\begin{array}{c}-0.327^{*} \\
(0.175)\end{array}$ & $\begin{array}{c}-0.563 * * * \\
(0.170)\end{array}$ & $\begin{array}{c}-0.381^{*} \\
(0.205)\end{array}$ \\
\hline ATE-AIPW Low & $\begin{array}{l}-0.061 \\
(0.066)\end{array}$ & $\begin{array}{c}-0.381 * * * \\
(0.089)\end{array}$ & $\begin{array}{c}-0.558^{* * * *} \\
(0.148)\end{array}$ & $\begin{array}{c}-1.059 * * * * \\
(0.171)\end{array}$ & $\begin{array}{c}-1.219^{* * *} \\
(0.219)\end{array}$ & $\begin{array}{c}-0.708^{* * *} \\
(0.230)\end{array}$ & ATE-AIPW Low & $\begin{array}{c}-0.569 * * * \\
(0.123)\end{array}$ & $\begin{array}{c}-0.571 * * * \\
(0.117)\end{array}$ & $\begin{array}{c}-1.008^{* * *} \\
(0.127)\end{array}$ & $\begin{array}{c}-1.483 * * * \\
(0.172)\end{array}$ & $\begin{array}{c}-1.644^{* * * *} \\
(0.167)\end{array}$ & $\begin{array}{c}-1.602 * * * \\
(0.198)\end{array}$ \\
\hline P-value High=Low & 0.000 & 0.001 & 0.000 & 0.000 & 0.000 & 0.000 & P-value High=Low & 0.000 & 0.885 & 0.000 & 0.000 & 0.000 & 0.000 \\
\hline Avg.(trade) in countries above cutoff & 0.334 & 0.836 & 1.347 & 1.870 & 2.339 & 2.875 & Avg.(trade) in countries above cutoff & 0.305 & 0.696 & 1.155 & 1.648 & 2.131 & 2.685 \\
\hline Avg.(trade) in countries below cutoff & 0.360 & 0.559 & 0.885 & 1.238 & 1.600 & 1.990 & Avg.(trade) in countries below cutoff & 0.328 & 0.566 & 0.715 & 0.968 & 1.207 & 1.474 \\
\hline \multicolumn{7}{|l|}{ Panel c: Mining } & \multicolumn{7}{|l|}{ Panel c: Mining } \\
\hline ATE-AIPW High & $\begin{array}{c}1.222 * * * \\
(0.234)\end{array}$ & $\begin{array}{c}0.135 \\
(0.299)\end{array}$ & $\begin{array}{c}0.016 \\
(0.305)\end{array}$ & $\begin{array}{l}-0.543 \\
(0.399)\end{array}$ & $\begin{array}{c}-0.284 \\
(0.511)\end{array}$ & $\begin{array}{c}1.031 \\
(0.677)\end{array}$ & ATE-AIPW High & $\begin{array}{c}-0.345^{* * * *} \\
(0.096)\end{array}$ & $\begin{array}{c}-0.735 * * * \\
(0.155)\end{array}$ & $\begin{array}{c}-0.924^{* * *} \\
(0.198)\end{array}$ & $\begin{array}{c}-1.202^{* * *} \\
(0.279)\end{array}$ & $\begin{array}{c}-1.273^{* * *} \\
(0.381)\end{array}$ & $\begin{array}{c}-1.067^{* *} \\
(0.497)\end{array}$ \\
\hline ATE-AIPW Low & $\begin{array}{c}-1.272 * * * \\
(0.151)\end{array}$ & $\begin{array}{c}-0.650^{* *} \\
(0.260)\end{array}$ & $\begin{array}{c}-1.548^{* * *} \\
(0.286)\end{array}$ & $\begin{array}{c}-3.413 * * * \\
(0.385)\end{array}$ & $\begin{array}{c}-2.674 * * * \\
(0.462)\end{array}$ & $\begin{array}{c}-3.749^{* * * *} \\
(0.624)\end{array}$ & ATE-AIPW Low & $\begin{array}{c}-0.887 * * * \\
(0.104)\end{array}$ & $\begin{array}{c}-0.560^{* * * *} \\
(0.188)\end{array}$ & $\begin{array}{c}-1.180^{* * *} \\
(0.225)\end{array}$ & $\begin{array}{c}-2.465 * * * \\
(0.273)\end{array}$ & $\begin{array}{c}-2.881 * * * \\
(0.345)\end{array}$ & $\begin{array}{c}-4.205 * * * \\
(0.443)\end{array}$ \\
\hline P-value High=Low & 0.000 & 0.000 & 0.000 & 0.000 & 0.000 & 0.000 & P-value High=Low & 0.000 & 0.242 & 0.126 & 0.000 & 0.000 & 0.000 \\
\hline Avg.(trade) in countries above cutoff & 0.728 & 1.450 & 2.278 & 3.228 & 3.960 & 4.537 & Avg.(trade) in countries above cutoff & 0.622 & 1.574 & 2.553 & 3.565 & 4.425 & 5.174 \\
\hline Avg.(trade) in countries below cutoff & 0.389 & 0.791 & 1.248 & 1.652 & 2.222 & 2.939 & Avg.(trade) in countries below cutoff & 0.563 & 0.774 & 1.087 & 1.383 & 1.747 & 2.090 \\
\hline \multicolumn{7}{|l|}{ Panel d: Manufacturing } & \multicolumn{7}{|l|}{ Panel d: Manufacturing } \\
\hline ATE-AIPW High & $\begin{array}{c}-0.699 * * * \\
(0.173)\end{array}$ & $\begin{array}{c}-1.348^{* * *} \\
(0.326)\end{array}$ & $\begin{array}{c}-2.259 * * * \\
(0.441)\end{array}$ & $\begin{array}{c}-3.706^{* * *} \\
(0.662)\end{array}$ & $\begin{array}{c}-4.987 * * * \\
(0.876)\end{array}$ & $\begin{array}{c}-5.339 * * * \\
(1.070)\end{array}$ & ATE-AIPW High & $\begin{array}{l}-0.782 * * \\
(0.333)\end{array}$ & $\begin{array}{c}-2.323 * * * \\
(0.463)\end{array}$ & $\begin{array}{l}-1.317^{*} \\
(0.679)\end{array}$ & $\begin{array}{c}-1.984 * * \\
(0.968)\end{array}$ & $\begin{array}{c}-3.403^{* * *} \\
(1.284)\end{array}$ & $\begin{array}{c}-3.627 * * \\
(1.662)\end{array}$ \\
\hline ATE-AIPW Low & $\begin{array}{c}-1.118^{* * *} \\
(0.157)\end{array}$ & $\begin{array}{c}-2.160 * * * \\
(0.281)\end{array}$ & $\begin{array}{c}-3.085 * * * \\
(0.436)\end{array}$ & $\begin{array}{c}-5.008^{* * *} \\
(0.661)\end{array}$ & $\begin{array}{c}-5.519^{* * *} \\
(0.878)\end{array}$ & $\begin{array}{c}-6.301 * * * \\
(1.066)\end{array}$ & ATE-AIPW Low & $\begin{array}{c}-4.116^{* * * *} \\
(0.328)\end{array}$ & $\begin{array}{c}-4.648^{* * * *} \\
(0.445)\end{array}$ & $\begin{array}{c}-6.818^{* * * *} \\
(0.657)\end{array}$ & $\begin{array}{c}-8.109 * * * \\
(0.942)\end{array}$ & $\begin{array}{c}-8.873^{* * *} \\
(1.277)\end{array}$ & $\begin{array}{c}-9.842^{* * * *} \\
(1.648)\end{array}$ \\
\hline P-value High=Low & 0.000 & 0.000 & 0.000 & 0.000 & 0.009 & 0.000 & $\overline{P \text { P-value High=Low }}$ & 0.000 & 0.000 & 0.000 & 0.000 & 0.000 & 0.000 \\
\hline Avg.(trade) in countries above cutoff & 1.367 & 3.063 & 4.766 & 6.409 & 7.974 & 9.593 & Avg.(trade) in countries above cutoff & 2.266 & 5.048 & 7.772 & 10.441 & 13.283 & 15.973 \\
\hline Avg.(trade) in countries below cutoff & 1.150 & 1.995 & 2.981 & 4.082 & 5.177 & 6.285 & Avg.(trade) in countries below cutoff & 1.327 & 1.959 & 2.951 & 4.258 & 5.668 & 7.514 \\
\hline \multicolumn{7}{|l|}{ Panel e: Services } & \multicolumn{7}{|l|}{ Panel e: Services } \\
\hline ATE-AIPW High & $\begin{array}{c}-0.201 * * * \\
(0.076)\end{array}$ & $\begin{array}{c}-0.703 * * * \\
(0.136)\end{array}$ & $\begin{array}{c}-0.526^{* * *} \\
(0.203)\end{array}$ & $\begin{array}{c}-0.757 * * * \\
(0.274)\end{array}$ & $\begin{array}{c}-1.605^{* * *} \\
(0.424)\end{array}$ & $\begin{array}{c}-2.020^{* * *} \\
(0.613)\end{array}$ & ATE-AIPW High & $\begin{array}{c}0.113 \\
(0.076)\end{array}$ & $\begin{array}{c}0.056 \\
(0.122)\end{array}$ & $\begin{array}{r}0.029 \\
(0.170)\end{array}$ & $\begin{array}{l}-0.063 \\
(0.214)\end{array}$ & $\begin{array}{l}-0.204 \\
(0.282)\end{array}$ & $\begin{array}{c}0.028 \\
(0.355)\end{array}$ \\
\hline ATE-AIPW Low & $-0.517^{* * *}$ & $-1.153 * * *$ & $-1.083 * * *$ & $-1.610^{* * *}$ & $-1.619^{* * *}$ & $-2.567^{* * *}$ & ATE-AIPW Low & $-1.868 * * *$ & $-2.247^{* * *}$ & $-3.072 * * *$ & $-3.026^{* * *}$ & $-2.987^{* * *}$ & $-3.450^{* * *}$ \\
\hline & $(0.073)$ & $(0.137)$ & $(0.205)$ & $(0.258)$ & $(0.421)$ & $(0.603)$ & & $(0.110)$ & $(0.131)$ & $(0.185)$ & $(0.216)$ & $(0.287)$ & $(0.351)$ \\
\hline P-value High=Low & 0.000 & 0.000 & 0.000 & 0.000 & 0.930 & 0.001 & P-value High=Low & 0.000 & 0.000 & 0.000 & 0.000 & 0.000 & 0.000 \\
\hline Avg.(trade) in countries above cutoff & 0.728 & 1.565 & 2.538 & 3.643 & 4.659 & 5.771 & Avg.(trade) in countries above cutoff & 0.577 & 1.333 & 2.169 & 3.095 & 3.973 & 4.837 \\
\hline Avg.(trade) in countries below cutoff & 0.673 & 1.206 & 1.795 & 2.304 & 2.958 & 3.534 & Avg.(trade) in countries below cutoff & 0.466 & 0.769 & 1.040 & 1.375 & 1.757 & 2.239 \\
\hline Observations & 576 & 576 & 576 & 576 & 576 & 576 & Observations & 576 & 576 & 576 & 576 & 576 & 576 \\
\hline \# of Crises & 15 & 15 & 15 & 15 & 15 & 15 & \# of Crises & 15 & 15 & 15 & 15 & 15 & 15 \\
\hline Cutoff of channel variable, median & -1.017 & -1.017 & -1.017 & -1.017 & -1.017 & -1.017 & Cutoff of channel variable, median & -1.017 & -1.017 & -1.017 & -1.017 & -1.017 & -1.017 \\
\hline
\end{tabular}

CInternational Monetary Fund. Not for Redistribution 
Table A.20c: Channels, Cumulative trade losses over five years after currency crises with higher and lower evolution of gross capital inflows

\begin{tabular}{|c|c|c|c|c|c|c|c|c|c|c|c|c|c|}
\hline \multicolumn{7}{|c|}{ Panel I: Exports (\% of pre-crisis GDP) } & \multicolumn{7}{|c|}{ Panel II: Imports (\% of pre-crisis GDP) } \\
\hline & (1) & (2) & (3) & (4) & (5) & (6) & & (1) & (2) & (3) & (4) & (5) & (6) \\
\hline & $\mathrm{h}=\mathbf{0}$ & $\mathrm{h}=1$ & $\mathrm{~h}=2$ & $\mathrm{~h}=\mathbf{3}$ & $h=4$ & $\mathrm{~h}=5$ & & $\mathrm{~h}=\mathbf{0}$ & $\mathrm{h}=1$ & $\mathrm{~h}=\mathbf{2}$ & $h=3$ & $h=4$ & $h=5$ \\
\hline \multicolumn{7}{|c|}{ Panel C: Currency crises } & \multicolumn{7}{|c|}{ Panel C: Currency crises } \\
\hline Panel a: Total & & & & & & & Panel a: Total & & & & & & \\
\hline ATE-AIPW High & $\begin{array}{c}-1.391^{* * *} \\
(0.314)\end{array}$ & $\begin{array}{c}-3.473 * * * \\
(0.473)\end{array}$ & $\begin{array}{c}-4.683 * * * \\
(0.672)\end{array}$ & $\begin{array}{c}*-5.104 * * * \\
(0.812)\end{array}$ & $\begin{array}{c}-5.993 * * * \\
(0.978)\end{array}$ & $\begin{array}{c}-5.173^{* * *} \\
(1.212)\end{array}$ & ATE-AIPW High & $\begin{array}{c}-5.233 * * * \\
(0.522)\end{array}$ & $\begin{array}{c}-6.613 * * * \\
(0.685)\end{array}$ & $\begin{array}{c}-8.501 * * * \\
(1.013)\end{array}$ & $\begin{array}{c}-9.139 * * * \\
(1.150)\end{array}$ & $\begin{array}{c}-8.097 * * * \\
(1.397)\end{array}$ & $\begin{array}{c}-4.712 * * * \\
(1.747)\end{array}$ \\
\hline ATE-AIPW Low & $\begin{array}{c}-3.920^{* * * *} \\
(0.443)\end{array}$ & $\begin{array}{c}-3.825 * * * \\
(0.529)\end{array}$ & $\begin{array}{c}-3.451 * * * \\
(0.694)\end{array}$ & $\begin{array}{c}*-4.278^{* * * *} \\
(0.843)\end{array}$ & $\begin{array}{c}-7.463 * * * \\
(0.974)\end{array}$ & $\begin{array}{c}-11.400^{* * *} \\
(1.172)\end{array}$ & ATE-AIPW Low & $\begin{array}{c}-7.220 * * * \\
(0.620)\end{array}$ & $\begin{array}{c}-8.368 * * * \\
(0.718)\end{array}$ & $\begin{array}{c}-8.167 * * * \\
(0.951)\end{array}$ & $\begin{array}{c}-8.152^{* * *} \\
(1.152)\end{array}$ & $\begin{array}{c}-9.938^{* * * *} \\
(1.447)\end{array}$ & $\begin{array}{c}-13.246 * * * \\
(1.704)\end{array}$ \\
\hline P-value High=Low & 0.000 & 0.280 & 0.002 & 0.095 & 0.010 & 0.000 & P-value High=Low & 0.000 & 0.000 & 0.540 & 0.081 & 0.007 & 0.000 \\
\hline Avg.(trade) in countries above cutoff & 3.116 & 6.885 & 10.831 & 14.932 & 18.658 & 22.547 & Avg.(trade) in countries above cutoff & 3.736 & 8.616 & 13.472 & 18.537 & 23.372 & 28.228 \\
\hline Avg.(trade) in countries below cutoff & 2.594 & 4.403 & 6.742 & 9.167 & 11.856 & 14.477 & Avg.(trade) in countries below cutoff & 2.651 & 3.743 & 5.446 & 7.450 & 10.028 & 12.806 \\
\hline \multicolumn{7}{|l|}{ Panel b: Agriculture } & Panel b: Agriculture & & & & & & \\
\hline ATE-AIPW High & $\begin{array}{c}0.022 \\
(0.058)\end{array}$ & $\begin{array}{c}-0.453 * * * \\
(0.080)\end{array}$ & $\begin{array}{l}-0.216^{*} \\
(0.110)\end{array}$ & $\begin{array}{c}-0.548^{* * *} \\
(0.137)\end{array}$ & $\begin{array}{c}-0.352 * * \\
(0.169)\end{array}$ & $\begin{array}{c}-0.523^{* *} \\
(0.213)\end{array}$ & ATE-AIPW High & $\begin{array}{c}-0.516^{* * * *} \\
(0.100)\end{array}$ & $\begin{array}{c}-0.702 * * * \\
(0.092)\end{array}$ & $\begin{array}{c}-0.881^{* * * *} \\
(0.144)\end{array}$ & $\begin{array}{c}-1.061^{* * *} \\
(0.138)\end{array}$ & $\begin{array}{c}-0.786^{* * *} \\
(0.168)\end{array}$ & $\begin{array}{c}-0.478^{* *} \\
(0.209)\end{array}$ \\
\hline ATE-AIPW Low & $\begin{array}{c}-0.152^{* *} \\
(0.069)\end{array}$ & $\begin{array}{l}-0.157 \\
(0.116)\end{array}$ & $\begin{array}{c}0.508^{* *} \\
(0.250)\end{array}$ & $\begin{array}{c}0.547^{* *} \\
(0.242)\end{array}$ & $\begin{array}{c}0.191 \\
(0.208)\end{array}$ & $\begin{array}{l}-0.144 \\
(0.227)\end{array}$ & ATE-AIPW Low & $\begin{array}{c}-0.486^{* * *} \\
(0.099)\end{array}$ & $\begin{array}{c}-0.446^{* * *} \\
(0.089)\end{array}$ & $\begin{array}{c}-0.647 * * * \\
(0.137)\end{array}$ & $\begin{array}{c}-0.617^{* * *} \\
(0.136)\end{array}$ & $\begin{array}{c}-0.734^{* * *} \\
(0.172)\end{array}$ & $\begin{array}{c}-0.971 * * * \\
(0.190)\end{array}$ \\
\hline $\begin{array}{l}\text { P-value High=Low } \\
\end{array}$ & 0.000 & 0.002 & 0.002 & 0.000 & 0.000 & 0.010 & P-value High=Low & 0.373 & 0.000 & 0.000 & 0.000 & 0.461 & 0.000 \\
\hline Avg.(trade) in countries above cutoff & 0.331 & 0.850 & 1.350 & 1.871 & 2.325 & 2.859 & Avg.(trade) in countries above cutoff & 0.324 & 0.720 & 1.161 & 1.660 & 2.112 & 2.670 \\
\hline Avg.(trade) in countries below cutoff & 0.368 & 0.510 & 0.841 & 1.183 & 1.563 & 1.942 & Avg.(trade) in countries below cutoff & 0.296 & 0.513 & 0.668 & 0.888 & 1.163 & 1.400 \\
\hline \multicolumn{7}{|l|}{$\begin{array}{l}\text { Panel c: Mining } \\
\end{array}$} & Panel c: Mining & & & & & & \\
\hline ATE-AIPW High & $\begin{array}{l}-0.050 \\
(0.170)\end{array}$ & $\begin{array}{c}-0.916^{* * *} \\
(0.186)\end{array}$ & $\begin{array}{c}-1.732 * * * \\
(0.297)\end{array}$ & $\begin{array}{c}* 1.444 * * * \\
(0.364)\end{array}$ & $\begin{array}{c}-2.146^{* * *} \\
(0.425)\end{array}$ & $\begin{array}{c}-2.086^{* * *} \\
(0.497)\end{array}$ & ATE-AIPW High & $\begin{array}{c}-1.311^{* * *} \\
(0.117)\end{array}$ & $\begin{array}{c}-1.649^{* * *} \\
(0.167)\end{array}$ & $\begin{array}{c}-2.671^{* * *} \\
(0.253)\end{array}$ & $\begin{array}{c}-2.818^{* * *} \\
(0.283)\end{array}$ & $\begin{array}{c}-2.972 * * * \\
(0.347)\end{array}$ & $\begin{array}{c}-2.470^{* * *} \\
(0.410)\end{array}$ \\
\hline ATE-AIPW Low & $\begin{array}{c}-0.792 * * * \\
(0.172)\end{array}$ & $\begin{array}{c}-1.139 * * * \\
(0.191)\end{array}$ & $\begin{array}{c}-1.147 * * * \\
(0.275)\end{array}$ & $\begin{array}{c}*-2.281^{* * * *} \\
(0.349)\end{array}$ & $\begin{array}{c}-3.745 * * * \\
(0.390)\end{array}$ & $\begin{array}{c}-4.119^{* * * *} \\
(0.462)\end{array}$ & ATE-AIPW Low & $\begin{array}{c}-1.337 * * * \\
(0.134)\end{array}$ & $\begin{array}{c}-1.571^{* * *} \\
(0.162)\end{array}$ & $\begin{array}{c}-1.514 * * * \\
(0.191)\end{array}$ & $\begin{array}{c}-2.131^{* * *} \\
(0.237)\end{array}$ & $\begin{array}{c}-2.994^{* * *} \\
(0.288)\end{array}$ & $\begin{array}{c}-3.550 * * * \\
(0.350)\end{array}$ \\
\hline P-value High=Low & 0.000 & 0.002 & 0.003 & 0.000 & 0.000 & 0.000 & P-value High=Low & 0.812 & 0.337 & 0.000 & 0.000 & 0.914 & 0.000 \\
\hline Avg.(trade) in countries above cutoff & 0.722 & 1.424 & 2.247 & 3.125 & 3.864 & 4.460 & Avg.(trade) in countries above cutoff & 0.603 & 1.550 & 2.502 & 3.501 & 4.334 & 5.057 \\
\hline Avg.(trade) in countries below cutoff & 0.371 & 0.782 & 1.216 & 1.702 & 2.246 & 2.942 & Avg.(trade) in countries below cutoff & 0.591 & 0.748 & 1.055 & 1.311 & 1.684 & 2.037 \\
\hline \multicolumn{7}{|l|}{ Panel d: Manufacturing } & Panel d: Manufacturing & & & & & & \\
\hline ATE-AIPW High & $\begin{array}{c}-0.669^{* * *} \\
(0.166)\end{array}$ & $\begin{array}{c}-1.470^{* * *} \\
(0.268)\end{array}$ & $\begin{array}{c}-2.130^{* * * *} \\
(0.358)\end{array}$ & $\begin{array}{c}* 2.236^{* * *} \\
(0.441)\end{array}$ & $\begin{array}{c}-2.385 * * * \\
(0.532)\end{array}$ & $\begin{array}{c}-1.582 * * \\
(0.633)\end{array}$ & ATE-AIPW High & $\begin{array}{c}-2.766 * * * \\
(0.315)\end{array}$ & $\begin{array}{c}-3.239^{* * *} \\
(0.402)\end{array}$ & $\begin{array}{c}-3.645^{* * *} \\
(0.554)\end{array}$ & $\begin{array}{c}-3.967^{* * *} \\
(0.660)\end{array}$ & $\begin{array}{c}-3.393 * * * \\
(0.794)\end{array}$ & $\begin{array}{l}-1.120 \\
(0.975)\end{array}$ \\
\hline \multirow[t]{2}{*}{ ATE-AIPW Low } & $-2.052^{* * *}$ & $-2.146 * *$ & $=-2.463 * *$ & $*-2.967 * * *$ & $-4.076^{* * * *}$ & $-5.641^{* * *}$ & ATE-AIPW Low & $-4.405^{* * *}$ & $-5.394 * * *$ & $-5.114 * * *$ & $-4.667^{* * * *}$ & $-5.449^{* * *}$ & $-7.367 * *$ \\
\hline & $(0.272)$ & $(0.320)$ & $(0.369)$ & $(0.458)$ & $(0.556)$ & $(0.672)$ & & $(0.375)$ & $(0.436)$ & $(0.565)$ & $(0.688)$ & $(0.853)$ & $(0.998)$ \\
\hline P-value High=Low & 0.000 & 0.003 & 0.112 & 0.008 & 0.000 & 0.000 & P-value High=Low & 0.000 & 0.000 & 0.000 & 0.036 & 0.000 & 0.000 \\
\hline Avg.(trade) in countries above cutoff & 1.359 & 3.053 & 4.692 & 6.315 & 7.855 & 9.512 & Avg.(trade) in countries above cutoff & 2.242 & 5.021 & 7.664 & 10.315 & 13.014 & 15.730 \\
\hline Avg.(trade) in countries below cutoff & 1.145 & 1.922 & 2.961 & 4.052 & 5.153 & 6.151 & Avg.(trade) in countries below cutoff & 1.292 & 1.745 & 2.736 & 3.959 & 5.502 & 7.232 \\
\hline \multicolumn{7}{|l|}{ Panel e: Services } & Panel e: Services & & & & & & \\
\hline ATE-AIPW High & $\begin{array}{c}-0.694^{* * * *} \\
(0.100)\end{array}$ & $\begin{array}{c}-0.634 * * * \\
(0.163)\end{array}$ & $\begin{array}{c}-0.605 * * * \\
(0.234)\end{array}$ & $\begin{array}{c}* 0.875 * * * \\
(0.296)\end{array}$ & $\begin{array}{c}-1.110^{* * *} \\
(0.346)\end{array}$ & $\begin{array}{c}-0.982^{* *} \\
(0.440)\end{array}$ & ATE-AIPW High & $\begin{array}{c}-0.641^{* * * *} \\
(0.090)\end{array}$ & $\begin{array}{c}-1.024^{* * *} \\
(0.144)\end{array}$ & $\begin{array}{c}-1.305^{* * *} \\
(0.196)\end{array}$ & $\begin{array}{c}-1.293^{* * *} \\
(0.215)\end{array}$ & $\begin{array}{c}-0.947 * * * \\
(0.277)\end{array}$ & $\begin{array}{l}-0.644 * \\
(0.347)\end{array}$ \\
\hline \multirow[t]{2}{*}{ ATE-AIPW Low } & $-0.924 * * *$ & $-0.384 * *$ & -0.349 & 0.423 & 0.168 & $-1.496 * *$ & ATE-AIPW Low & $-0.992 * * *$ & $-0.957^{* * *}$ & $-0.892 * * *$ & $-0.736^{* * *}$ & $-0.761 * * *$ & $-1.358 * * *$ \\
\hline & $(0.102)$ & $(0.145)$ & $(0.216)$ & $(0.296)$ & $(0.349)$ & $(0.414)$ & & $(0.099)$ & $(0.148)$ & $(0.187)$ & $(0.221)$ & $(0.271)$ & $(0.304)$ \\
\hline P-value High=Low & 0.001 & 0.043 & 0.155 & 0.000 & 0.000 & 0.175 & P-value High=Low & 0.000 & 0.463 & 0.001 & 0.000 & 0.387 & 0.015 \\
\hline Avg.(trade) in countries above cutoff & 0.704 & 1.557 & 2.542 & 3.621 & 4.614 & 5.716 & Avg.(trade) in countries above cutoff & 0.567 & 1.324 & 2.145 & 3.060 & 3.912 & 4.771 \\
\hline Avg.(trade) in countries below cutoff & 0.710 & 1.190 & 1.724 & 2.230 & 2.894 & 3.443 & Avg.(trade) in countries below cutoff & 0.473 & 0.737 & 0.988 & 1.292 & 1.679 & 2.137 \\
\hline Observations & 579 & 579 & 579 & 579 & 579 & 579 & Observations & 579 & 579 & 579 & 579 & 579 & 579 \\
\hline \# of Crises & 15 & 15 & 15 & 15 & 15 & 15 & \# of Crises & 15 & 15 & 15 & 15 & 15 & 15 \\
\hline Cutoff of channel variable, median & -1.371 & -1.371 & -1.371 & -1.371 & -1.371 & -1.371 & Cutoff of channel variable, median & -1.371 & -1.371 & -1.371 & -1.371 & -1.371 & -1.371 \\
\hline
\end{tabular}

CInternational Monetary Fund. Not for Redistribution 
Table A.21a: Channels, Cumulative trade losses over five years after debt crises with higher and lower evolution of investors' credit ratings risks

\begin{tabular}{|c|c|c|c|c|c|c|}
\hline \multicolumn{7}{|c|}{ Panel I: Exports (\% of pre-crisis GDP) } \\
\hline & (1) & (2) & (3) & (4) & (5) & (6) \\
\hline & $\mathrm{h}=\mathbf{0}$ & $\mathrm{h}=1$ & $\mathrm{~h}=\mathbf{2}$ & $h=3$ & $h=4$ & $\mathrm{~h}=5$ \\
\hline \multicolumn{7}{|c|}{ Panel A: Debt crises } \\
\hline \multicolumn{7}{|l|}{ Panel a: Total } \\
\hline ATE-AIPW High & $\begin{array}{c}-0.921 * * * \\
(0.321)\end{array}$ & $\begin{array}{c}-1.214 * * * \\
(0.416)\end{array}$ & $\begin{array}{c}-1.386^{* *} \\
(0.610)\end{array}$ & $\begin{array}{c}-3.828^{* * * *} \\
(0.859)\end{array}$ & $\begin{array}{c}-3.383 * * * \\
(1.111)\end{array}$ & $\begin{array}{l}-2.395^{*} \\
(1.398)\end{array}$ \\
\hline ATE-AIPW Low & $-0.812^{* * *}$ & $-3.913 * * *$ & $-6.050^{* * *}$ & $-8.587 * * *$ & $-9.814 * * *$ & $-10.174^{* * *}$ \\
\hline & $(0.282)$ & $(0.412)$ & $(0.607)$ & $(0.861)$ & $(1.056)$ & $(1.277)$ \\
\hline P-value High=Low & 0.697 & 0.000 & 0.000 & 0.000 & 0.000 & 0.000 \\
\hline Avg.(trade) in countries above cutoff & 2.978 & 6.358 & 10.305 & 14.546 & 18.777 & 23.345 \\
\hline Avg.(trade) in countries below cutoff & 0.231 & -0.010 & 1.075 & 2.520 & 3.834 & 5.983 \\
\hline \multicolumn{7}{|l|}{ Panel b: Agriculture } \\
\hline ATE-AIPW High & $\begin{array}{l}-0.118 \\
(0.141)\end{array}$ & $\begin{array}{c}0.608^{* * *} \\
(0.151)\end{array}$ & $\begin{array}{c}0.969^{* * *} \\
(0.179)\end{array}$ & $\begin{array}{c}1.295^{* * * *} \\
(0.295)\end{array}$ & $\begin{array}{c}2.104^{* * *} \\
(0.405)\end{array}$ & $\begin{array}{c}3.875 * * * \\
(0.680)\end{array}$ \\
\hline ATE-AIPW Low & $\begin{array}{c}0.068 \\
(0.062)\end{array}$ & $\begin{array}{c}-0.259 * * \\
(0.107)\end{array}$ & $\begin{array}{c}-0.464 * * * \\
(0.143)\end{array}$ & $\begin{array}{c}-0.142 \\
(0.196)\end{array}$ & $\begin{array}{c}-0.133 \\
(0.238)\end{array}$ & $\begin{array}{c}0.274 \\
(0.323)\end{array}$ \\
\hline P-value High=Low & 0.177 & 0.000 & 0.000 & 0.000 & 0.000 & 0.000 \\
\hline Avg.(trade) in countries above cutoff & 0.358 & 0.794 & 1.295 & 1.793 & 2.316 & 2.947 \\
\hline Avg.(trade) in countries below cutoff & 0.155 & 0.074 & 0.301 & 0.712 & 1.042 & 1.583 \\
\hline \multicolumn{7}{|l|}{ Panel c: Mining } \\
\hline ATE-AIPW High & $\begin{array}{c}0.080 \\
(0.201)\end{array}$ & $\begin{array}{c}0.491^{* *} \\
(0.200)\end{array}$ & $\begin{array}{c}0.156 \\
(0.251)\end{array}$ & $\begin{array}{c}-0.837 * * * \\
(0.324)\end{array}$ & $\begin{array}{c}0.052 \\
(0.417)\end{array}$ & $\begin{array}{c}0.856 \\
(0.548)\end{array}$ \\
\hline ATE-AIPW Low & $\begin{array}{l}0.286^{*} \\
(0.154)\end{array}$ & $\begin{array}{c}-0.773 * * * \\
(0.159)\end{array}$ & $\begin{array}{c}-0.955 * * * \\
(0.235)\end{array}$ & $\begin{array}{c}-1.965^{* * *} \\
(0.371)\end{array}$ & $\begin{array}{c}-1.890^{* * * *} \\
(0.426)\end{array}$ & $\begin{array}{c}-1.606^{* * *} * \\
(0.506)\end{array}$ \\
\hline P-value High=Low & 0.306 & 0.000 & 0.000 & 0.000 & 0.000 & 0.000 \\
\hline Avg.(trade) in countries above cutoff & 0.451 & 1.032 & 1.808 & 2.691 & 3.588 & 4.476 \\
\hline Avg.(trade) in countries below cutoff & -0.247 & -0.498 & -0.542 & -0.593 & -0.569 & -0.325 \\
\hline \multicolumn{7}{|l|}{ Panel d: Manufacturing } \\
\hline ATE-AIPW High & $\begin{array}{c}-0.710^{* * * *} \\
(0.128)\end{array}$ & $\begin{array}{c}-1.565^{* * * *} \\
(0.214)\end{array}$ & $\begin{array}{c}-2.010^{* * * *} \\
(0.323)\end{array}$ & $\begin{array}{c}-3.354 * * * \\
(0.424)\end{array}$ & $\begin{array}{c}-4.374 * * * \\
(0.545)\end{array}$ & $\begin{array}{c}-5.061 * * * \\
(0.650)\end{array}$ \\
\hline ATE-AIPW Low & $\begin{array}{c}-0.601 * * * \\
(0.120)\end{array}$ & $\begin{array}{c}-1.196^{* * *} \\
(0.212)\end{array}$ & $\begin{array}{c}-2.437 * * * \\
(0.311)\end{array}$ & $\begin{array}{c}-3.856^{* * * *} \\
(0.419)\end{array}$ & $\begin{array}{c}-4.750^{* * * *} \\
(0.529)\end{array}$ & $\begin{array}{c}-5.512 * * * \\
(0.637)\end{array}$ \\
\hline P-value High=Low & 0.056 & 0.000 & 0.000 & 0.000 & 0.022 & 0.017 \\
\hline Avg.(trade) in countries above cutoff & 1.265 & 2.710 & 4.328 & 6.099 & 7.849 & 9.740 \\
\hline Avg.(trade) in countries below cutoff & 0.267 & 0.290 & 0.993 & 1.693 & 2.233 & 3.020 \\
\hline \multicolumn{7}{|l|}{ Panel e: Services } \\
\hline ATE-AIPW High & $\begin{array}{c}-0.173^{* *} \\
(0.084)\end{array}$ & $\begin{array}{c}-0.749 * * * \\
(0.143)\end{array}$ & $\begin{array}{c}-0.502 * * \\
(0.204)\end{array}$ & $\begin{array}{c}-0.931 * * * \\
(0.260)\end{array}$ & $\begin{array}{c}-1.165^{* * * *} \\
(0.302)\end{array}$ & $\begin{array}{c}-2.064 * * * \\
(0.354)\end{array}$ \\
\hline ATE-AIPW Low & $-0.565^{* * *}$ & $-1.684 * * *$ & $-2.194 * * *$ & $-2.624 * * *$ & $-3.042 * * *$ & $-3.330^{* * *}$ \\
\hline & $(0.086)$ & $(0.137)$ & $(0.195)$ & $(0.246)$ & $(0.291)$ & $(0.352)$ \\
\hline P-value High=Low & 0.000 & 0.000 & 0.000 & 0.000 & 0.000 & 0.000 \\
\hline Avg.(trade) in countries above cutoff & 0.905 & 1.822 & 2.873 & 3.963 & 5.024 & 6.183 \\
\hline Avg.(trade) in countries below cutoff & 0.055 & 0.124 & 0.324 & 0.708 & 1.128 & 1.706 \\
\hline Observations & 627 & 627 & 627 & 627 & 627 & 627 \\
\hline \# of Crises & 18 & 18 & 18 & 18 & 18 & 18 \\
\hline Cutoff of channel variable, median & -5.567 & -5.567 & -5.567 & -5.567 & -5.567 & -5.567 \\
\hline
\end{tabular}

\begin{tabular}{|c|c|c|c|c|c|c|}
\hline \multicolumn{7}{|c|}{ Panel II: Imports (\% of pre-crisis GDP) } \\
\hline & (1) & (2) & (3) & (4) & (5) & (6) \\
\hline & $\mathbf{h}=\mathbf{0}$ & $\mathrm{h}=1$ & $\mathrm{~h}=\mathbf{2}$ & $h=3$ & $h=4$ & $h=5$ \\
\hline \multicolumn{7}{|c|}{ Panel A: Debt crises } \\
\hline \multicolumn{7}{|l|}{ Panel a: Total } \\
\hline ATE-AIPW High & $\begin{array}{c}-1.601 * * * \\
(0.426)\end{array}$ & $\begin{array}{c}-2.344^{* * * *} \\
(0.580)\end{array}$ & $\begin{array}{c}-1.690^{*} \\
(0.896)\end{array}$ & $\begin{array}{c}-0.923 \\
(1.197)\end{array}$ & $\begin{array}{c}-1.036 \\
(1.470)\end{array}$ & $\begin{array}{c}1.391 \\
(1.977)\end{array}$ \\
\hline \multirow[t]{2}{*}{ ATE-AIPW Low } & $-4.820^{* * * *}$ & $*-10.537^{* * *}$ & $-12.064^{* * *}$ & $-14.338^{* * *}$ & $-16.217^{* * * *}$ & $-17.600^{* * *}$ \\
\hline & $(0.536)$ & $(0.619)$ & $(0.941)$ & $(1.218)$ & $(1.418)$ & $(1.713)$ \\
\hline P-value High=Low & 0.000 & 0.000 & 0.000 & 0.000 & 0.000 & 0.000 \\
\hline Avg.(trade) in countries above cutoff & 3.788 & 8.141 & 12.819 & 17.750 & 22.800 & 28.183 \\
\hline Avg.(trade) in countries below cutoff & -1.147 & -2.884 & -2.379 & -0.824 & 0.693 & 2.899 \\
\hline \multicolumn{7}{|l|}{ Panel b: Agriculture } \\
\hline ATE-AIPW High & $\begin{array}{c}-0.097 \\
(0.116)\end{array}$ & $\begin{array}{c}-0.225^{* *} \\
(0.110)\end{array}$ & $\begin{array}{c}-0.092 \\
(0.141)\end{array}$ & $\begin{array}{c}-0.117 \\
(0.188)\end{array}$ & $\begin{array}{c}-0.222 \\
(0.161)\end{array}$ & $\begin{array}{c}0.295 \\
(0.201)\end{array}$ \\
\hline \multirow[t]{2}{*}{ ATE-AIPW Low } & -0.166 & $-1.021^{* * *}$ & $-1.148^{* * *}$ & $-1.609^{* * *}$ & $-1.798 * * *$ & $-1.954 * * *$ \\
\hline & $(0.122)$ & $(0.115)$ & $(0.146)$ & $(0.195)$ & $(0.168)$ & $(0.202)$ \\
\hline P-value High=Low & 0.142 & 0.000 & 0.000 & 0.000 & 0.000 & 0.000 \\
\hline Avg.(trade) in countries above cutoff & 0.342 & 0.716 & 1.160 & 1.629 & 2.107 & 2.627 \\
\hline Avg.(trade) in countries below cutoff & -0.105 & -0.157 & -0.091 & 0.065 & 0.172 & 0.373 \\
\hline \multicolumn{7}{|l|}{ Panel c: Mining } \\
\hline ATE-AIPW High & $\begin{array}{c}-0.586^{* * *} * \\
(0.095)\end{array}$ & $\begin{array}{c}-0.503^{* * *} * \\
(0.144)\end{array}$ & $\begin{array}{c}-0.865^{* * * *} \\
(0.197)\end{array}$ & $\begin{array}{c}-0.932 * * * \\
(0.275)\end{array}$ & $\begin{array}{c}-0.544^{*} \\
(0.326)\end{array}$ & $\begin{array}{c}-0.341 \\
(0.448)\end{array}$ \\
\hline \multirow[t]{2}{*}{ ATE-AIPW Low } & $-0.403 * * *$ & $*-1.004 * * *$ & $-1.216 * *$ & $-2.166^{* * *}$ & $-2.608^{* * *}$ & $-2.604 * * *$ \\
\hline & $(0.085)$ & $(0.137)$ & $(0.191)$ & $(0.267)$ & $(0.316)$ & $(0.430)$ \\
\hline P-value High=Low & 0.009 & 0.000 & 0.008 & 0.000 & 0.000 & 0.000 \\
\hline Avg.(trade) in countries above cutoff & 0.546 & 1.223 & 2.023 & 2.956 & 3.912 & 4.900 \\
\hline Avg.(trade) in countries below cutoff & -0.197 & -0.406 & -0.158 & 0.016 & 0.020 & 0.228 \\
\hline \multicolumn{7}{|l|}{ Panel d: Manufactur } \\
\hline \multirow[t]{2}{*}{ ATE-AIPW High } & $-0.754 * * *$ & * $-1.064 * * *$ & & 0.962 & 0.519 & 2.077 \\
\hline & $(0.256)$ & $(0.366)$ & $(0.560)$ & $(0.748)$ & $(0.953)$ & $(1.314)$ \\
\hline \multirow[t]{2}{*}{ ATE-AIPW Low } & $-2.893 * * *$ & $*-6.238^{* * * *}$ & $-7.030^{* * *}$ & $-7.858^{* * * *}$ & $-8.661 * * *$ & $-9.637 * * *$ \\
\hline & $(0.316)$ & $(0.371)$ & $(0.561)$ & $(0.708)$ & $(0.829)$ & $(0.975)$ \\
\hline P-value High=Low & 0.000 & 0.000 & 0.000 & 0.000 & 0.000 & 0.000 \\
\hline Avg.(trade) in countries above cutoff & 2.204 & 4.739 & 7.389 & 10.093 & 12.882 & 15.881 \\
\hline Avg.(trade) in countries below cutoff & -0.658 & -1.872 & -1.579 & -0.675 & 0.447 & 1.776 \\
\hline
\end{tabular}

\begin{tabular}{|c|}
\hline Panel e: Services \\
\hline
\end{tabular}

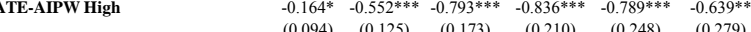

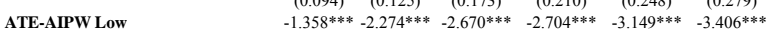

\begin{tabular}{lcccccc} 
& $(0.116)$ & $(0.125)$ & $(0.172)$ & $(0.209)$ & $(0.245)$ & $(0.286)$ \\
\hline P-value High=Low & 0.000 & 0.000 & 0.000 & 0.000 & 0.000 & 0.000
\end{tabular}

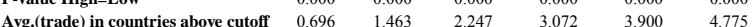

\begin{tabular}{llllll} 
Avg.(trade) in & 0.000 & 4.775 \\
\hline
\end{tabular}

\begin{tabular}{lcccccc} 
Avg.(trade) in countries below cutoff & -0.188 & -0.449 & -0.551 & -0.230 & 0.054 & 0.521 \\
\hline Observations & 627 & 627 & 627 & 627 & 627 & 627 \\
Oof Crises & 18 & 18 & 18 & 18 & 18 & 18
\end{tabular}

\begin{tabular}{cccccc}
18 & 18 & 18 & 18 & 18 & 18 \\
-5.567 & -5.567 & -5.567 & -5.567 & -5.567 & -5.567 \\
\hline
\end{tabular}

Notes: Robust stand cos the cumulative change of agricultural, mining, 作 treated and control groups are weighted by the propensity scores predicted in the treatment model. Maximum weights truncated at 10 . 
Table A.21c: Channels, Cumulative trade losses over five years after currency crises with higher and lower evolution of investors' credit ratings risks

\begin{tabular}{|c|c|c|c|c|c|c|c|c|c|c|c|c|c|}
\hline \multicolumn{7}{|c|}{ Panel I: Exports (\% of pre-crisis GDP) } & \multicolumn{7}{|c|}{ Panel II: Imports (\% of pre-crisis GDP) } \\
\hline & (1) & (2) & (3) & (4) & (5) & (6) & & (1) & (2) & (3) & (4) & (5) & (6) \\
\hline & $\mathrm{h}=\mathbf{0}$ & $\mathrm{h}=1$ & $\mathrm{~h}=\mathbf{2}$ & $h=3$ & $h=4$ & $h=5$ & & $\mathrm{~h}=\mathbf{0}$ & $\mathrm{h}=\mathbf{1}$ & $\mathrm{h}=\mathbf{2}$ & $\mathrm{h}=\mathbf{3}$ & $h=4$ & $h=5$ \\
\hline \multirow{2}{*}{\multicolumn{7}{|c|}{ Panel C: Currency crises }} & \multicolumn{7}{|c|}{ Panel C: Currency crises } \\
\hline Panel a: Total & & & & & & & Panel a: Total & & & & & & \\
\hline ATE-AIPW High & $\begin{array}{c}-0.686^{* *} \\
(0.325)\end{array}$ & $\begin{array}{c}-2.269 * * * \\
(0.432)\end{array}$ & $\begin{array}{c}-3.408^{* * *} \\
(0.578)\end{array}$ & $\begin{array}{c}*-3.764 * * * \\
(0.763)\end{array}$ & $\begin{array}{c}-5.295 * * * \\
(0.882)\end{array}$ & $\begin{array}{c}-6.311^{* * *} \\
(1.115)\end{array}$ & ATE-AIPW High & $\begin{array}{c}-3.086 * * * \\
(0.463)\end{array}$ & $\begin{array}{c}-4.540^{* * *} \\
(0.612)\end{array}$ & $\begin{array}{c}-6.405 * * * \\
(0.882)\end{array}$ & $\begin{array}{c}-8.495 * * * \\
(1.078)\end{array}$ & $\begin{array}{c}-8.893 * * * \\
(1.283)\end{array}$ & $\begin{array}{c}-6.775^{* * *} \\
(1.580)\end{array}$ \\
\hline \multirow[t]{2}{*}{ ATE-AIPW Low } & $-3.485 * * *$ & $*-3.967 * * *$ & * $-4.424 * * *$ & $*-6.777 * * *$ & $-10.375 * * *$ & $-13.722 * * *$ & ATE-AIPW Low & $-7.322 * * *$ & $-9.207 * * *$ & $-9.981 * * *$ & $-10.584^{* * *}$ & $*-13.025^{* * *}$ & $-17.237 * * *$ \\
\hline & $(0.405)$ & $(0.454)$ & $(0.663)$ & $(0.819)$ & $(0.952)$ & $(1.175)$ & & $(0.571)$ & $(0.684)$ & $(0.885)$ & $(1.151)$ & $(1.388)$ & $(1.753)$ \\
\hline P-value High=Low & 0.000 & 0.000 & 0.024 & 0.000 & 0.000 & 0.000 & P-value High=Low & 0.000 & 0.000 & 0.000 & 0.001 & 0.000 & 0.000 \\
\hline Avg.(trade) in countries above cutoff & 2.992 & 6.470 & 10.572 & 14.938 & 19.333 & 24.126 & Avg.(trade) in countries above cutoff & 3.852 & 8.450 & 13.474 & 18.622 & 23.806 & 29.408 \\
\hline Avg.(trade) in countries below cutoff & 0.938 & 1.257 & 2.425 & 4.075 & 5.444 & 7.228 & Avg.(trade) in countries below cutoff & -0.059 & -1.225 & -1.161 & 0.337 & 2.221 & 4.302 \\
\hline \multicolumn{7}{|l|}{ Panel b: Agriculture } & Panel b: Agriculture & & & & & & \\
\hline ATE-AIPW High & $\begin{array}{l}0.187^{* *} \\
(0.075)\end{array}$ & $\begin{array}{c}-0.222 * * \\
(0.089)\end{array}$ & $\begin{array}{c}-0.108 \\
(0.119)\end{array}$ & $\begin{array}{c}-0.394^{* * *} \\
(0.150)\end{array}$ & $\begin{array}{l}-0.163 \\
(0.187)\end{array}$ & $\begin{array}{l}-0.146 \\
(0.245)\end{array}$ & ATE-AIPW High & $\begin{array}{c}-0.286^{* * *} \\
(0.093)\end{array}$ & $\begin{array}{c}-0.437^{* * *} \\
(0.083)\end{array}$ & $\begin{array}{c}-0.631 * * * \\
(0.108)\end{array}$ & $\begin{array}{c}-0.873 * * * \\
(0.123)\end{array}$ & $\begin{array}{c}-0.686^{* * *} \\
(0.145)\end{array}$ & $\begin{array}{c}-0.344^{* *} \\
(0.173)\end{array}$ \\
\hline ATE-AIPW Low & $\begin{array}{c}0.005 \\
(0.066)\end{array}$ & $\begin{array}{c}-0.093 \\
(0.130)\end{array}$ & $\begin{array}{l}0.566 * * \\
(0.253)\end{array}$ & $\begin{array}{l}0.450^{*} \\
(0.267)\end{array}$ & $\begin{array}{r}-0.096 \\
(0.265)\end{array}$ & $\begin{array}{l}-0.421 \\
(0.341)\end{array}$ & ATE-AIPW Low & $\begin{array}{c}-0.517 * * * \\
(0.091)\end{array}$ & $\begin{array}{c}-0.584 * * * \\
(0.076)\end{array}$ & $\begin{array}{c}-0.851^{* * * *} \\
(0.103)\end{array}$ & $\begin{array}{c}-1.001 * * * \\
(0.118)\end{array}$ & $\begin{array}{c}-1.103 * * * \\
(0.146)\end{array}$ & $\begin{array}{c}-1.581^{* * *} \\
(0.161)\end{array}$ \\
\hline $\begin{array}{l}\text { P-value High=Low } \\
\end{array}$ & 0.009 & 0.291 & 0.006 & 0.000 & 0.756 & 0.359 & P-value High=Low & 0.000 & 0.004 & 0.000 & 0.032 & 0.000 & 0.000 \\
\hline Avg.(trade) in countries above cutoff & 0.364 & 0.799 & 1.292 & 1.783 & 2.315 & 2.970 & Avg.(trade) in countries above cutoff & 0.345 & 0.734 & 1.205 & 1.700 & 2.183 & 2.727 \\
\hline Avg.(trade) in countries below cutoff & 0.181 & 0.253 & 0.593 & 1.065 & 1.405 & 1.855 & Avg.(trade) in countries below cutoff & 0.006 & 0.006 & 0.050 & 0.175 & 0.359 & 0.541 \\
\hline \multicolumn{7}{|l|}{ Panel c: Mining } & Panel c: Mining & & & & & & \\
\hline ATE-AIPW High & $\begin{array}{l}-0.004 \\
(0.233)\end{array}$ & $\begin{array}{c}-0.794 * * * \\
(0.185)\end{array}$ & $\begin{array}{c}-0.971^{* * * *} \\
(0.242)\end{array}$ & $\begin{array}{c}* 1.087^{* * *} \\
(0.309)\end{array}$ & $\begin{array}{c}-1.980^{* * *} \\
(0.360)\end{array}$ & $\begin{array}{c}-2.426^{* * *} \\
(0.444)\end{array}$ & ATE-AIPW High & $\begin{array}{c}-0.826^{* * * *} \\
(0.104)\end{array}$ & $\begin{array}{c}-1.169^{* * *} \\
(0.145)\end{array}$ & $\begin{array}{c}-2.179 * * * \\
(0.202)\end{array}$ & $\begin{array}{c}-2.677^{* * *} \\
(0.234)\end{array}$ & $\begin{array}{c}-3.228^{* * *} \\
(0.277)\end{array}$ & $\begin{array}{c}-3.155^{* * *} \\
(0.331)\end{array}$ \\
\hline ATE-AIPW Low & $\begin{array}{c}-0.497^{* * *} \\
(0.222)\end{array}$ & $\begin{array}{c}-0.655 * * * \\
(0.161)\end{array}$ & $\begin{array}{c}-1.218^{* * * *} \\
(0.266)\end{array}$ & $\begin{array}{c}* 1.888^{* * * *} \\
(0.303)\end{array}$ & $\begin{array}{c}-3.295 * * * \\
(0.353)\end{array}$ & $\begin{array}{c}-3.343^{* * * *} \\
(0.406)\end{array}$ & ATE-AIPW Low & $\begin{array}{c}-1.143 * * * \\
(0.124)\end{array}$ & $\begin{array}{c}-1.211 * * * \\
(0.152)\end{array}$ & $\begin{array}{c}-1.270^{* * *} \\
(0.186)\end{array}$ & $\begin{array}{c}-1.816^{* * *} \\
(0.248)\end{array}$ & $\begin{array}{c}-2.713 * * * \\
(0.287)\end{array}$ & $\begin{array}{c}-3.251^{* * * *} \\
(0.424)\end{array}$ \\
\hline P-value High=Low & 0.000 & 0.206 & 0.196 & 0.000 & 0.000 & 0.000 & P-value High=Low & 0.004 & 0.687 & 0.000 & 0.000 & 0.010 & 0.794 \\
\hline Avg.(trade) in countries above cutoff & 0.461 & 1.050 & & 2.766 & 3.732 & 4.686 & Avg.(trade) in countries above cutoff & 0.546 & 1.275 & 2.128 & 3.074 & 4.044 & 5.094 \\
\hline Avg.(trade) in countries below cutoff & -0.099 & -0.153 & -0.065 & -0.019 & -0.073 & 0.047 & Avg.(trade) in countries below cutoff & 0.013 & -0.190 & -0.033 & 0.293 & 0.499 & 0.635 \\
\hline \multicolumn{7}{|l|}{ Panel d: Manufacturing } & Panel d: Manufacturing & & & & & & \\
\hline ATE-AIPW High & $\begin{array}{c}-0.554 * * * \\
(0.133)\end{array}$ & $\begin{array}{c}*-1.074 * * * \\
(0.242)\end{array}$ & $\begin{array}{c}-2.147 * * * \\
(0.322)\end{array}$ & $\begin{array}{c}* 2.499 * * * \\
(0.426)\end{array}$ & $\begin{array}{c}-3.146^{* * *} \\
(0.519)\end{array}$ & $\begin{array}{c}-3.571^{* * *} \\
(0.622)\end{array}$ & ATE-AIPW High & $\begin{array}{c}-1.538^{* * * *} \\
(0.282)\end{array}$ & $\begin{array}{c}-2.314 * * * \\
(0.368)\end{array}$ & $\begin{array}{c}-2.946 * * * \\
(0.511)\end{array}$ & $\begin{array}{c}-4.364^{* * * *} \\
(0.639)\end{array}$ & $\begin{array}{c}-4.606 * * * \\
(0.764)\end{array}$ & $\begin{array}{c}-3.002^{* * *} \\
(0.932)\end{array}$ \\
\hline \multirow[t]{2}{*}{ ATE-AIPW Low } & $-1.673^{* * *}$ & $*-1.916 * * *$ & $*-2.219^{* * *}$ & $*-3.191 * * *$ & $-4.404 * * *$ & $-5.756^{* * * *}$ & ATE-AIPW Low & $-4.558^{* * * *}$ & $-5.753 * *$ & $-6.005^{* * *}$ & $-5.682 * * *$ & $-6.911^{* * *}$ & $-9.234 * * *$ \\
\hline & $(0.221)$ & $(0.245)$ & $(0.313)$ & $(0.428)$ & $(0.542)$ & $(0.671)$ & & $(0.344)$ & $(0.418)$ & $(0.529)$ & $(0.691)$ & $(0.846)$ & $(1.043)$ \\
\hline \multirow{3}{*}{$\begin{array}{l}\text { P-value High=Low } \\
\text { Avg.(trade) in countries above cutoff } \\
\text { Avg.(trade) in countries below cutoff }\end{array}$} & 0.000 & 0.000 & 0.701 & 0.009 & 0.000 & 0.000 & P-value High=Low & 0.000 & 0.000 & 0.000 & 0.000 & 0.000 & 0.000 \\
\hline & 1.249 & 2.744 & 4.460 & 6.287 & 8.086 & 10.057 & Avg.(trade) in countries above cutoff & 2.254 & 4.930 & 7.800 & 10.639 & 13.497 & 16.585 \\
\hline & 0.620 & 0.815 & 1.319 & 2.052 & 2.706 & 3.430 & Avg.(trade) in countries below cutoff & -0.086 & -0.905 & -0.976 & -0.190 & 1.077 & 2.466 \\
\hline \multicolumn{7}{|l|}{ Panel e: Services } & Panel e: Services & & & & & & \\
\hline ATE-AIPW High & $\begin{array}{c}-0.315^{* * *} \\
(0.083)\end{array}$ & $\begin{array}{ll}* & -0.179 \\
& (0.145)\end{array}$ & $\begin{array}{l}-0.182 \\
(0.208)\end{array}$ & $\begin{array}{c}0.215 \\
(0.296)\end{array}$ & $\begin{array}{l}-0.006 \\
(0.342)\end{array}$ & $\begin{array}{l}-0.169 \\
(0.416)\end{array}$ & ATE-AIPW High & $\begin{array}{c}-0.436 * * * \\
(0.077)\end{array}$ & $\begin{array}{c}-0.620^{* * *} \\
(0.126)\end{array}$ & $\begin{array}{c}-0.648^{* * *} \\
(0.194)\end{array}$ & $\begin{array}{c}-0.580^{* *} \\
(0.231)\end{array}$ & $\begin{array}{l}-0.373 \\
(0.272)\end{array}$ & $\begin{array}{l}-0.275 \\
(0.316\end{array}$ \\
\hline \multirow[t]{2}{*}{ ATE-AIPW Low } & $-1.320^{* * *}$ & $*-1.303^{* * *}$ & * $-1.553^{* * *}$ & $*-2.148 * * *$ & $-2.581^{* * *}$ & $-4.202 * * *$ & ATE-AIPW Low & $-1.104 * * *$ & $-1.659 * * *$ & $-1.854 * * *$ & $-2.084 * * *$ & $-2.299 * * *$ & $-3.171^{* * *}$ \\
\hline & $(0.084)$ & $(0.138)$ & $(0.191)$ & $(0.249)$ & $(0.295)$ & $(0.362)$ & & $(0.091)$ & $(0.133)$ & $(0.189)$ & $(0.222)$ & $(0.246)$ & $(0.280)$ \\
\hline P-value High=Low & 0.000 & 0.000 & 0.000 & 0.000 & 0.000 & 0.000 & P-value High=Low & 0.000 & 0.000 & 0.000 & 0.000 & 0.000 & 0.000 \\
\hline Avg.(trade) in countries above cutoff & 0.918 & 1.877 & 2.972 & 4.102 & 5.199 & 6.412 & Avg.(trade) in countries above cutoff & 0.707 & 1.511 & 2.341 & 3.209 & 4.082 & 5.002 \\
\hline Avg.(trade) in countries below cutoff & 0.236 & 0.342 & 0.578 & 0.976 & 1.406 & 1.896 & Avg.(trade) in countries below cutoff & 0.008 & -0.137 & -0.202 & 0.060 & 0.287 & 0.660 \\
\hline Observations & 627 & 627 & 627 & 627 & 627 & 627 & Observations & 627 & 627 & 627 & 627 & 627 & 627 \\
\hline \# of Crises & 18 & 18 & 18 & 18 & 18 & 18 & \# of Crises & 18 & 18 & 18 & 18 & 18 & 18 \\
\hline Cutoff of channel variable, median & -3.509 & -3.509 & -3.509 & -3.509 & -3.509 & -3.509 & Cutoff of channel variable, median & -3.509 & -3.509 & -3.509 & -3.509 & -3.509 & -3.509 \\
\hline
\end{tabular}

